\section{US Army Corps} ngineers

\section{US-CE-C Property of the}

United States Government

\title{
Return Velocity and Drawdown in Navigable Waterways
}

by Steve Maynord

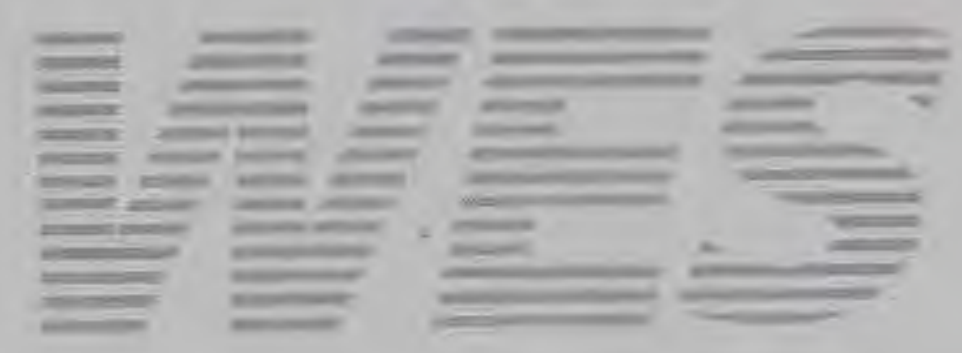

Approved For Public Release; Distribution Is Unlimited

Research Library

US Army Engineer Waterways

Experiment Station

Vicksburg. Mississippi

Prepared for Headquarters, U.S. Army Corps of Engineers 


\section{Return Velocity and Drawdown in Navigable Waterways}

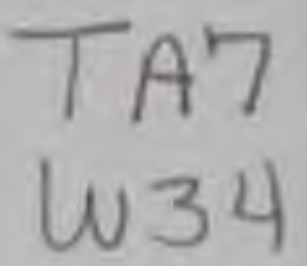

by Steve Maynord

U.S. Army Corps of Engineers

Waterways Experiment Station

3909 Halls Ferry Road

Vicksburg, MS 39180-6199

Final report

Approved for public release; distribution is unlimited 


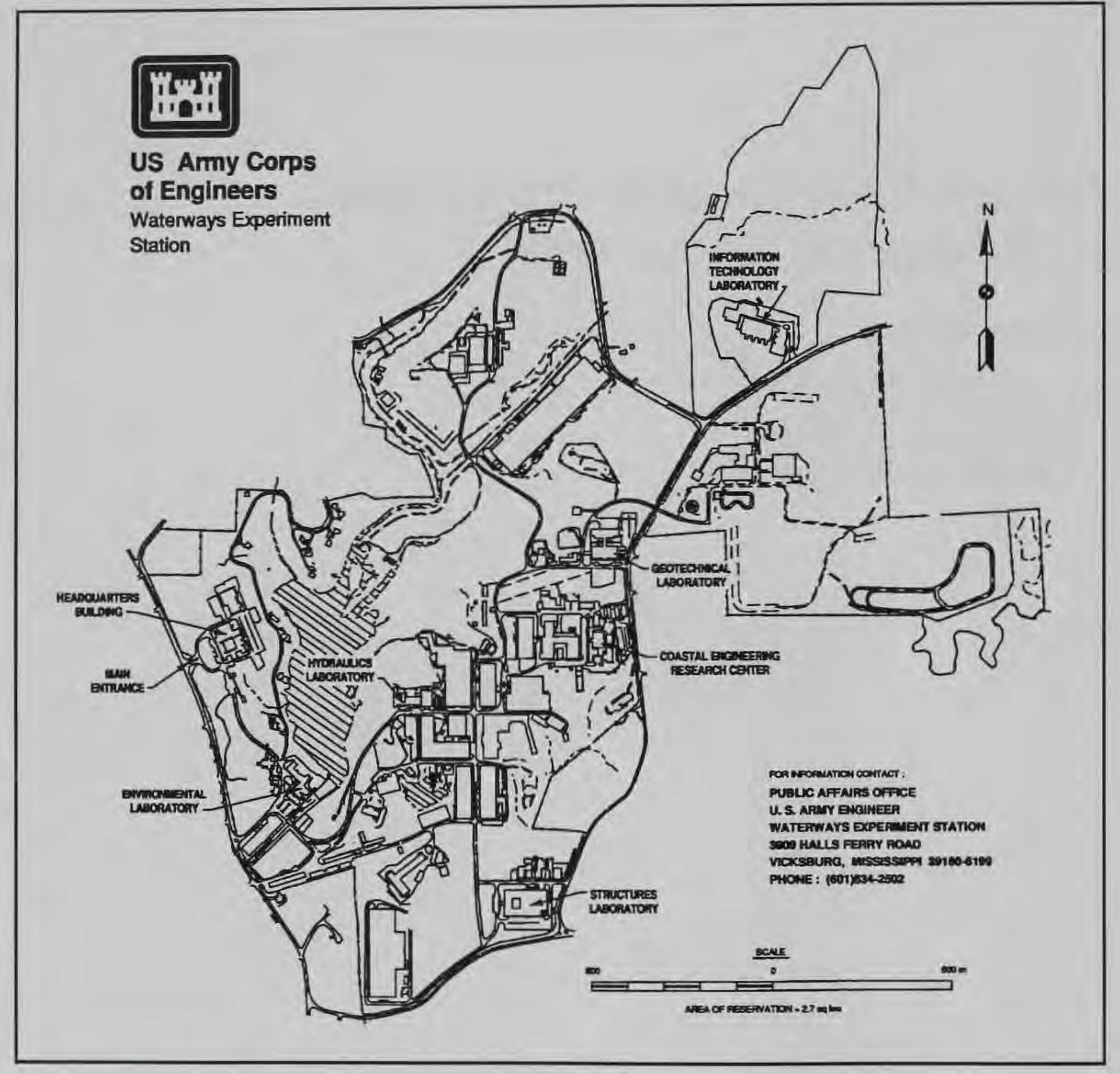

Waterways Experiment Station Cataloging-in-Publication Data

Maynord, Stephen T.

Return velocity and drawdown in navigable waterways / by Steve Maynord ; prepared for U.S. Army Corps of Engineers.

102 p. : ill. ; $28 \mathrm{~cm}$. - (Technical report ; HL-96-7)

Includes bibliographical references.

1. Channels (Hydraulic engineering) - Mississippi River. 2. Barges - Mississippi River. 3. Navigation - Mississippi River. 4. Drainage - Mississippi River. I. United States. Army. Corps of Engineers. II. U.S. Army Engineer Waterways Experiment Station. III. Hydraulics Laboratory (U.S. Army Engineer Waterways Experiment Station) IV. Title. V. Series: Technical report (U.S. Army Engineer Waterways Experiment Station) ; HL-96-7.

TA7 W34 no.HL-96-7 


\section{Contents}

Preface $\ldots \ldots \ldots \ldots \ldots \ldots \ldots \ldots \ldots \ldots$ vii

1 -Introduction $\ldots \ldots \ldots \ldots \ldots \ldots \ldots \ldots \ldots \ldots \ldots \ldots \ldots \ldots \ldots \ldots$

Background . . . . . . . . . . . . . . . . . . . . . 1

Objective and Scope $\ldots \ldots \ldots \ldots \ldots \ldots \ldots \ldots \ldots$

2-Application of Confined Channel Methods to Large Waterways .... . 3

Previous Confined Channel Studies ................. 3

Modification of Confined Channel Methods to Large Waterways . . . . . 5

Large Waterway Studies . . . . . . . . . . . . . . . . 5

3-Return Velocity and Drawdown Data Sources, Errors, and Analysis .. 9

4-1991 and 1995 Analytical Methods . . . . . . . . . . . . . 12

Return Current Comparisons with 1991 Analytical Method . . . . . . 12

1995 Analytical Method . . . . . . . . . . . . . . . . . . . . 13

5-Development of 1995 Analytical Method for Prediction of

Water-Level Drawdown . . . . . . . . . . . . . . . . 47

6-Comparison of 1995 Analytical Method with Independent Field Data . 52

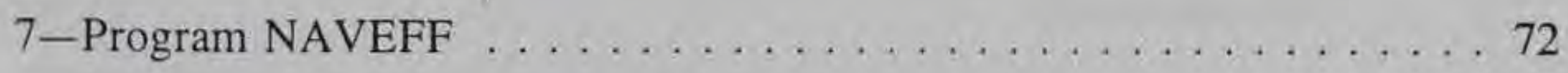

$8-$ Results and Conclusions $\ldots \ldots \ldots \ldots \ldots$

References . . . . . . . . . . . . . . . . 88

Appendix A: Notation . . . . . . . . . . . . . A1

SF 298 


\section{List of Figures}

Figure 1. Navigation effects: $\mathrm{A}=$ return velocity; $\mathrm{B}=$ drawdown; $\mathrm{C}=$ propeller jet; $\mathrm{D}=$ wake flow; $\mathrm{E}=$ bow wave; and $\mathrm{F}=$ slope supply flow. . . . . . . . . . . . . .

Figure 2. Cross section of the Illinois River at the Kampsville site for

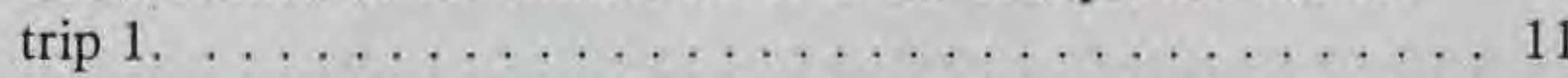

Figure 3. Observed physical model return velocity versus computed return velocity using 1991 analytical method. . . . . . . . . 13

Figure 4. Observed prototype return velocity versus computed return velocity using 1991 analytical method. . . . . . . . . . 14

Figure 5. Observed physical model average return velocity versus computed Schijf return velocity . . . . . . . . . 16

Figure 6. $\quad \mathrm{V}_{\mathrm{rs}} / \mathrm{V}_{\mathrm{r}}$ versus $\mathrm{B}_{\text {side }} / \mathrm{B}_{\text {total }}$ using physical model data. . . . . 17

Figure 7. $\quad \mathrm{V}_{\mathrm{rsm}} / \mathrm{V}_{\mathrm{rs}}$ versus $\mathrm{N}_{\text {side }}$ using physical model data $\ldots \ldots \ldots 18$

Figure 8. Observed Kampsville physical model return velocity versus computed return velocity using 1995 analytical method . . . . 20

Figure 9. Observed Kampsville physical model return velocity versus computed return velocity using 1995 analytical method for individual tests . . . . . . . . . . . . . . . 21

Figure 10. Observed Kampsville physical model return velocity versus computed return velocity using 1995 analytical method for individual tests

Figure 11. Observed Kampsville physical model return velocity versus computed return velocity using 1995 analytical method for individual tests ................... 25

Figure 12. Observed Kampsville physical model return velocity versus computed return velocity using 1995 analytical method for individual tests

Figure 13. Observed Kampsville physical model return velocity versus computed return velocity using 1995 analytical method for individual tests $\ldots \ldots \ldots \ldots \ldots \ldots \ldots \ldots \ldots$ 
Figure 14. Observed Clark's Ferry physical model return velocity versus computed return velocity using 1995 analytical method for $\mathrm{N}<52$

Figure 15. Observed Clark's Ferry physical model return velocity versus computed return velocity using 1995 analytical method for $\mathrm{N}=85 \ldots \ldots \ldots \ldots \ldots \ldots \ldots \ldots \ldots \ldots \ldots \ldots \ldots$

Figure 16. Observed Kampsville prototype return velocity versus computed return velocity using 1995 analytical method .........35

Figure 17. Observed Clark's Ferry prototype return velocity versus computed return velocity using 1995 analytical method ... . . 36

Figure 18. Observed Kampsville prototype return velocity versus computed return velocity using 1995 analytical method for individual tests 37

Figure 19. Observed Kampsville prototype return velocity versus computed return velocity using 1995 analytical method for individual tests 39

Figure 20. Observed Kampsville prototype return velocity versus computed return velocity using 1995 analytical method for individual tests 41

Figure 21. Observed Kampsville prototype return velocity versus computed return velocity using 1995 analytical method for individual tests 43

Figure 22. Observed Kampsville physical model drawdown versus computed drawdown using 1995 analytical method . . . . . . . . . . 49

Figure 23. Observed Clark's Ferry physical model drawdown versus computed drawdown using 1995 analytical method . . . . 50

Figure 24. Observed Kampsville prototype drawdown versus computed drawdown using 1995 analytical method . . . . . . . . . 51

Figure 25. Observed ESE prototype return velocity versus computed return velocity using 1995 analytical method $\ldots \ldots \ldots \ldots \ldots 53$

Figure 26. Cross section for ORL tests $89192-89196 \ldots \ldots \ldots$. . . . . 54

Figure 27. Cross section for ORL tests $89198-89203 \ldots \ldots 55$

Figure 28. Cross section for ORL tests $90172-90179 \ldots \ldots$. . . . . . 56

Figure 29. Cross section for ORL tests $90191-90195 \ldots \ldots \ldots$. . . . . 57

Figure 30. Observed ORL prototype return velocity versus computed return velocity using 1995 analytical method ........... 70 
Figure 31. Observed ORL prototype drawdown versus computed drawdown using 1995 analytical method $\ldots \ldots \ldots \ldots \ldots \ldots$

Figure 32 . Listing for PC program NAVEFF . . . . . . . . . 73

Figure 33. Output from PC program NAVEFF ... . . . . . 85

\section{Tables}

Table 1. Physical Model Experimental Conditions ........... 31

Table 2. Kampsville Prototype Experimental Conditions .... . . . . . 45

Table 3. Observed Versus Computed Drawdown for WC Norman Test 51

Table 4. ORL Test $89192-89196 \ldots \ldots \ldots \ldots \ldots \ldots$

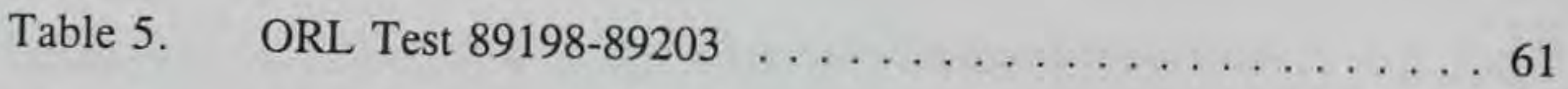

Table 6. ORL Test $90172-90179 \ldots \ldots \ldots \ldots \ldots \ldots$

Table 7. ORL Test $90191-90195 \ldots \ldots \ldots \ldots \ldots \ldots 6 \ldots \ldots \ldots \ldots \ldots$ 


\section{Preface}

The work described in this report was conducted at the U.S. Army Engineer Waterways Experiment Station (WES) during the period June 1995 to September 1995. This investigation was sponsored by Headquarters, U.S. Army Corps of Engineers (HQUSACE), under the Navigation Hydraulics Research Program as part of the Civil Works Investigation Work Unit, "Vessel Generated Forces and Protection," under HQUSACE Program Monitor Mr. Sam Powell.

The study was accomplished in the Hydraulics Laboratory (HL) under the direction of Mr. Richard A. Sager, Acting Director; Mr. Robert Athow, Acting Assistant Director; and Dr. Larry L. Daggett, Acting Chief, Navigation Division (HN). The study was conducted and the report was written by Dr. S. T. Maynord, Navigation Effects Group, HN.

At the time of publication of this report, Director of WES was Dr. Robert W. Whalin. Commander was COL Bruce K. Howard, EN.

The contents of this report are not to be used for advertising, publication, or promotional purposes. Citation of trade names does not constitute an official endorsement or approval of the use of such commercial products. 


\section{Introduction}

\section{Background}

A vessel moving in a navigation channel displaces water and creates a flow of water (return velocity) alongside the vessel in a direction opposite that of the vessel. The magnitude of the return velocity is primarily dependent on vessel speed, channel cross section, and the submerged cross-sectional area of the vessel. The return velocity is also accompanied by a lowering of the water level alongside the vessel, drawdown, as well as other navigation effects shown in Figure 1. Return velocity and drawdown have been extensively studied in prismatic cross sections and confined or restricted channels, i.e., those having a low blockage ratio $\mathrm{N}$, the ratio of channel cross-sectional area to vessel cross-sectional area. Previous studies (Permanent International Association of Navigation Congresses (PIANC) 1987, Schijf 1949) have addressed the channel stability aspects of return velocity and drawdown in

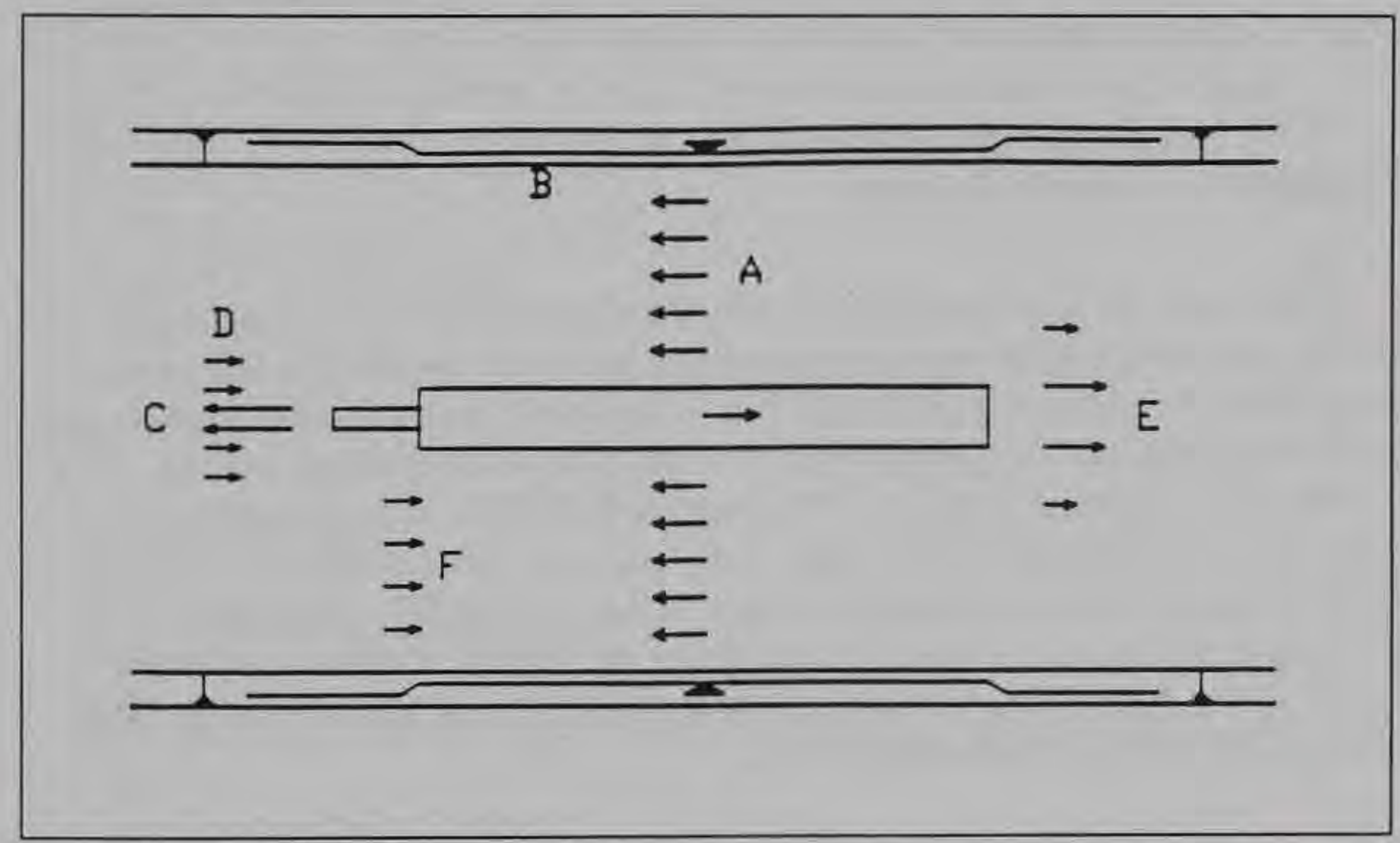

Figure 1. Navigation effects: $A=$ return velocity; $B=$ drawdown; $C=$ propellor jet; $D=$ wake flow; $E=$ bow wave; and $F=$ slope supply flow 
confined channels. In other studies (Blaauw and van der Knaap 1983, Tothill 1966), a primary concern of drawdown has been the resulting lowering or squat that the vessel experiences when drawdown occurs. In confined channels, vessel speeds can be limited by vessel squat when depth/draft ratios are
low.

In a general sense, return velocity and drawdown are analogous to pier or obstruction effects in a river. For piers that are small relative to the size of the river, large effects are found near the pier and negligible effects near the bank. If the pier took up a greater portion of the river, the effects would be large near the pier and significant near the bank. Finally, as the pier begins to dominate the cross section, the effects near the pier and near the bank are similar in magnitude. Because return velocity and drawdown follow these trends, mathematical decay functions whose shape varies with the vessel crosssectional area relative to the cross-sectional area of the river are used to describe the distribution of return velocity and drawdown between the vessel and the bank line. For a large vessel size relative to the river, the decay functions should collapse to an almost uniform distribution from bank to

Return velocity and drawdown are of interest in assessing the effects of navigation on environmental concerns for large navigable waterways. Channel stability and vessel squat impacts due to return velocity and drawdown are often small in large waterways like the Ohio and Mississippi where blockage ratios become large. One exception is areas where vessels travel near bank lines such as in lock approaches. The analytical techniques for estimating return velocity and drawdown developed for confined channels are not directly applicable to large waterways because many basic assumptions used in their development are not met in large waterways.

\section{Objective and Scope}

This study develops techniques for estimating return velocity and drawdown from commercial vessels operating in navigable waterways and compares them to model and prototype data. Confined channel methods are modified to extend their application to large riverine navigation systems. The results are incorporated into the PC program NAVEFF with this report serving as the documentation. This study does not address other navigation effects such as waves or propeller flows shown in Figure 1. This report presents a modification and an expansion of the results presented in Maynord and Siemsen (1991) and uses data from shallow draft navigation on the Ohio,
Illinois, and Upper Mississippi Rivers. 


\section{Application of Confined Channel Methods to Large Waterways}

\section{Previous Confined Channel Studies}

An excellent review of techniques to determine squat, drawdown, and return velocity in confined channels is presented by Blaauw and Van der Knaap (1983). Only the most pertinent studies are discussed in the following paragraphs.

Schijf's (1949) conservation of energy approach is frequently used in determining return velocity and drawdown in confined channels. The basic assumptions required in this approach are: uniform trapezoidal or rectangular cross section, uniform return current velocity from vessel to bank line, uniform drawdown from vessel to bank line, friction losses disregarded, uniform or negligible ambient velocity; and vessel on channel center line. Considering all motions relative to the vessel, continuity requires that

$$
V A_{c}=A_{w}(V+V)^{1}
$$

where

$$
\begin{aligned}
& V=\text { vessel speed } \\
& A_{c}=\text { undisturbed channel area } \\
& A_{i v}=\text { disturbed channel area around midsection of vessel excluding } A_{m} \\
& V_{r}=\text { average return velocity }
\end{aligned}
$$

\footnotetext{
For convenience, symbols and abbreviations are listed in the notation (Appendix A).
} 


$$
A_{m}=\text { submerged cross-sectional area of the vessel at the midsection }
$$

Conservation of energy requires that

$$
\frac{V^{2}}{2 g}+h=\frac{\left(V+V_{r}\right)^{2}}{2 g}+(h-z)
$$

where

$$
\begin{aligned}
& g=\text { gravitational acceleration } \\
& h=\text { undisturbed average water depth } \\
& z=\text { average water-level drawdown }
\end{aligned}
$$

The unknown quantities $V$, and $z$ can be determined from Equations 1 and 2 . Differentiation of Equations 1 and 2 leads to a maximum speed (called the critical or limiting speed $V_{L}$ ) which can not be exceeded by a self-propelled vessel and has been verified in both model and prototype investigations. PIANC (1987) presents a coefficient $\beta$ that varies with $V / V_{L}$ in the Schijf equations to improve agreement between observed and computed return velocity and drawdown. The energy equation is rewritten as

$$
\frac{V^{2}}{2 g}+h=\frac{\beta\left(V+V_{r}\right)^{2}}{2 g}+(h-z)
$$

Gates and Herbich (1977) included the displacement thickness from boundary layer concepts to determine effective vessel draft and beam improving the agreement between Schijf equations and prototype measurements of vessel squat. Inclusion of boundary layer concepts partially addresses the assumption requiring that friction losses be disregarded.

Bouwmeester et al. (1977) reported that Schijf (1949) cannot be used even approximately for $\mathrm{N}$ greater than about 33 because water-level drawdown and return velocity are greatly nonuniform. Many tows in large waterways have a value of $\mathrm{N}$ greater than 33 .

PIANC (1987) documented techniques for using the Schijf (1949) equations in channel stability investigations of prismatic channels. Schijf is recommended for $B_{o} / B$ from 2 to 12 , where $B_{o}$ is the channel width and $B$ is the beam of the vessel. Additionally, the ratio of channel width to vessel length $L$ can be a significant factor in defining the ratio of maximum water-level drawdown to average water-level drawdown and maximum return velocity to average return velocity. Channels having a large ratio $L / B_{o}$ will have a 
well-defined return velocity and drawdown time-history during the time the tow is adjacent to a given point on the bank.

\section{Modification of Confined Channel Methods to Large Waterways}

Some of the six basic assumptions for applying the Schijf equations are often not met in large waterways. The ambient and return velocities and the water-level drawdown are not uniform, the cross section is not prismatic, and the vessel is not on the channel center line. The equations determine average values of return velocity and drawdown. Maximum values near the shore are of the most interest for both channel bank stability and environmental concerns. Environmental interests often also require the variation in return velocity and drawdown between vessel and shoreline. The techniques presented here predict, at any given point between vessel and shoreline, the maximum deviation from ambient conditions due to return velocity and drawdown during the tow passage.

A major problem that must be overcome in evaluating asymmetric channels found in large waterways like the Ohio, Mississippi, or Illinois Rivers is how to handle tows off the channel center line. One technique assumes a mirror image on each side of the tow and computes average return velocity and drawdown. This is satisfactory until the tow gets near one bank line and far from the other resulting in a substantial amount of the return flow passing around the front of and beneath the tow. Then, the return current predicted on the side near the bank using the mirror image channel is much larger than actually occurs.

A second problem with the Schijf equation is in certain asymmetric channel shapes. Any channel with wide shallow areas on either or both channel sides is particularly subject to overestimating the return velocity at high vessel speeds. This problem becomes significant when tow speeds exceed about 90 percent of Schijf $V_{L}$ for the total section and when the ratio of maximum depth to average depth exceeds about 1.3. Fortunately most tows are traveling at less than $0.9 V_{L}$, normally from 50 to 75 percent of $V_{L}$.

\section{Large Waterways Studies}

Hochstein and Adams (1989) documented a technique for estimating return velocity on the upper Mississippi River that is used by Environmental Science and Engineering (ESE) (1981) and Simons et al (1988) and on the Ohio River by U.S. Army Engineer District, Huntington (1980). The average return

velocity is defined as 


$$
V_{r}=V\left[\left(a B_{T}-B_{T}+1\right)^{0.5}-1\right]
$$

where $a=(\mathrm{N} /(\mathrm{N}-1))^{2.5}$

For vessel speeds less than $0.65 \mathrm{~V}_{\mathrm{L}}$, where $B_{T}$ is a coefficient defined as $B_{T}$ $=0.3 \exp \left(1.8 \mathrm{~V} / \mathrm{V}_{\mathrm{L}}\right)$ and for vessel speeds equal to or greater than $0.65 \mathrm{~V}_{\mathrm{L}}$, $\mathrm{B}_{\mathrm{T}}=1$. From Maynord and Siemsen (1991), the Schijf and Hochstein average return velocity equations give similar results for vessel speeds equal to 50 to 60 percent of Schijf $V_{L}$. In Equations 5 through 7 , Hochstein presents a method for determining the return velocity distribution. A channel/tow width factor is defined as

$$
\alpha=\max \left(1,0.114 \frac{B_{o}}{B}+0.715\right)
$$

The maximum return velocity $V_{m}$ at the vessel is determined from

$$
V_{m}=\alpha V_{r}
$$

For $\alpha=1$, the distribution of velocity is uniform from vessel to bank line. For $1<\alpha<1.5$, the distribution of return velocity is linear. For $\alpha$ $\geq 1.5$, the distribution of return velocity is linear. For $\alpha \geq$, the distribution of return velocity from vessel to bank line is defined as

$$
V_{r}(Y)=V_{m} \exp (-Y / k)
$$

where

$$
\begin{aligned}
V_{r}(Y)= & \begin{array}{r}
\text { maximum return velocity during tow event at distance } Y \text { from } \\
\text { center line of vessel }
\end{array} \\
k= & \mathrm{B}_{\text {side }} /(\alpha\{1-\exp [-\mathrm{F}(\alpha) \alpha]\}) \\
B_{\text {side }}= & \text { distance from vessel center line to shoreline } \\
F(\alpha)= & 0.42+0.52 \ln \alpha
\end{aligned}
$$


ESE(1981), Simons et al. (1988), and USAED Huntington (1980) results showed that the Hochstein equations (Equations 4 through 7) underestimate measured return velocity.

Maynord and Siemsen (1991) presented a method for estimating return velocity in large waterways. Average return velocity is computed using Schijf (1949) without the correction factor. To handle tows navigating off the channel center line in asymmetric channels, the average return velocity is then proportioned on each side of the vessel using the following equation developed from physical model studies reported in Maynord (1990)

$$
\frac{V_{r s}}{V_{r}}=C_{1} S K E W+C_{2}
$$

where

$$
\begin{aligned}
V_{r s} & =\text { average return velocity for each side of vessel } \\
S K E W & =\mathrm{A}_{\mathrm{c}} /\left(2 \mathrm{~A}_{\text {side }}\right) \\
A_{\text {side }} & =\text { cross-sectional area from tow center line to bank line }
\end{aligned}
$$

Maynord and Siemsen (1991) used coefficients of $C_{1}=0.36$ and $C_{2}=0.64$ in Equation 8. The ratio $\alpha$ ' of the maximum return velocity on each side of the tow $V_{r s m}$ to $V_{r s}$ is determined from

$$
\frac{V_{r s m}}{V_{r s}}=\alpha^{\prime}=\max \left[1,0.024 N_{\text {side }}+0.734\right]
$$

where $N_{\text {side }}=2 \mathrm{~A}_{\text {side }} / \mathrm{A}_{\mathrm{m}}$.

Note the similarity between Hochstein's Equations 5 and 6 which use a width ratio and Equation 9 which uses an area ratio. As the area ratio $\left(\mathrm{N}_{\text {side }}\right)$ increases, the distribution of return velocity becomes nonuniform. From Equation $9, \mathrm{~N}_{\text {side }}$ less than 11 gives $\alpha^{\prime}=1$ and the distribution of return velocity between vessel and shoreline is uniform. The return velocity distribution from tow to bank line is determined from

$$
\frac{V_{r}(Y)}{V_{r s m}}=\exp \left[-C\left(\frac{Y-B}{B_{\text {side }}-B}\right)\right]
$$

where 


$$
C=1.2\left(\alpha^{\prime}-1\right)
$$

$V_{r}(Y)$ is the maximum return velocity during the tow event for a given distance $Y$ from the vessel center line. $V_{r}(Y)$ is linearly added to ambient currents for upbound tows and subtracted from ambient currents for downbound tows. $Y$ must be greater than $B$, because from $\mathrm{Y}=0$ to $\mathrm{Y}=\mathrm{B}$ the velocity is also affected by flow under the barges which can be considerably larger than the return velocity. Based on a limited data set used in Maynord and Siemsen (1991), the Hochstein method underestimated the measured return velocities while the Maynord and Siemsen (1991) method overestimated the measured return velocities.

An obvious limitation of these distribution equations is that the distribution does not vary with the shape or local depth of an asymmetric cross section, although both methods do address a vessel off the channel center line. For the remainder of this report, Equations 1, 2, and 8 through 11 are referred to as the 1991 analytical method. 


\section{Return Velocity and Drawdown Data Sources, Errors, and Analysis}

Prototype data on navigation effects have been collected on the Upper Mississippi, Illinois, and Ohio Rivers. One major limitation of these data is that only a few points were collected between the vessel and the bank line, primarily in the near-bank zone. Consequently, these data can not provide a verification of the velocity distribution shape and the return velocity magnitude outside the near bank zone. Physical model studies of reaches on the Upper Mississippi River were conducted where return velocity and drawdown were measured from shore to vessel to define the distribution of return velocity and drawdown. The physical model tests simulated a reach of the Illinois River near Kampsville and the Mississippi River near Clark's Ferry where the Illinois State Water Survey (ISWS) (Bhowmik, Soong, and Xia 1993a,b) conducted prototype measurements of tow-induced return velocity and drawdown. The physical model was verified by comparing model and prototype results for six tow events in each river reach. Agreement was reached between model and prototype return velocity and drawdown by reducing the physical model draft. Details of the Kampsville and Clark's Ferry physical model studies and the data used herein are provided in Maynord and Martin (1996a,b).

As with many data collection efforts, collection of return velocity and water level drawdown data is not an easy task in either the physical model or the prototype. Some error sources are specific to either model or prototype or applicable to both. Errors in instrumentation along with details of other potential error sources in the physical model testing are discussed in the physical model reports.

Instrument error in the ISWS prototype tests must be considered in using prototype data because of the environmental conditions found in the prototype. Electromagnetic velocity meters were used in the ISWS prototype studies and can be subject to a variety of problems. Radio interference can result in highly erratic readings. Drift can accumulate around the sensor head and modify readings in a manner that is not obvious to the person conducting the 
tests. Nevertheless, the electromagnetic velocity meter is the best available prototype technique for this type of measurement. Wave data collected in the ISWS tests were frequently missing due to instrument malfunction.

Tow length and width are relatively easy to determine in the field as long as the tow is comprised of the standard 10.7 by 59.5 ( 35 - by 195 -ft) barges. When chemical barges are present, their nonuniformity of length and width can be a problem. Tow length is important because the length and time of passage past a given point are often used to determine the tow speed in prototype tests. Tow draft may also contribute to the data scatter. Tows are assumed to draft $2.7 \mathrm{~m}(9 \mathrm{ft})$ if loaded and $0.6 \mathrm{~m}(2 \mathrm{ft})$ if unloaded unless contact with the towboat captain indicates otherwise. Mixed tows further complicate the issue.

Also the vertical location of velocity measurements is considered. Variations caused by this effect are not as significant as it might first appear since tow-induced return velocity profiles are generally uniform. The boundary layer resulting from tow passage does not have sufficient time to completely develop into the typical velocity profile found in a fully developed open channel flow. Therefore, velocity changes near the surface should be uniform down to the point where the boundary layer has developed. Results from the ISWS tests provided in Maynord and Martin (1996a) suggest that only meters 1001 and 998 (Figure 2) in the trip 1 data should not be used in the comparison with the 1991 analytical method because of the boundary layer influence.

One of the greatest causes of data variability is determining the tow impact from the time-history of the parameter of interest. The difficulty of this task increases as the magnitude of the tow impact decreases, because it becomes more difficult to distinguish the tow impact from the natural variations present in the river. The first task in defining the tow impact is defining the ambient velocity prior to tow passage which can be a problem as there are some long period variations in the ambient velocity due to several factors such as changes in the regulating gates at the locks and dams. The next task is defining the maximum deviation from ambient conditions. In the ISWS tests, the maximum (or minimum) value from an 11 -sec moving average was selected during the time the tow was adjacent to the meter. This smoothing technique eliminated the normal variations present in turbulent flow while also defining the maximum value. The difference between the maximum value and the ambient was the tow impact. 


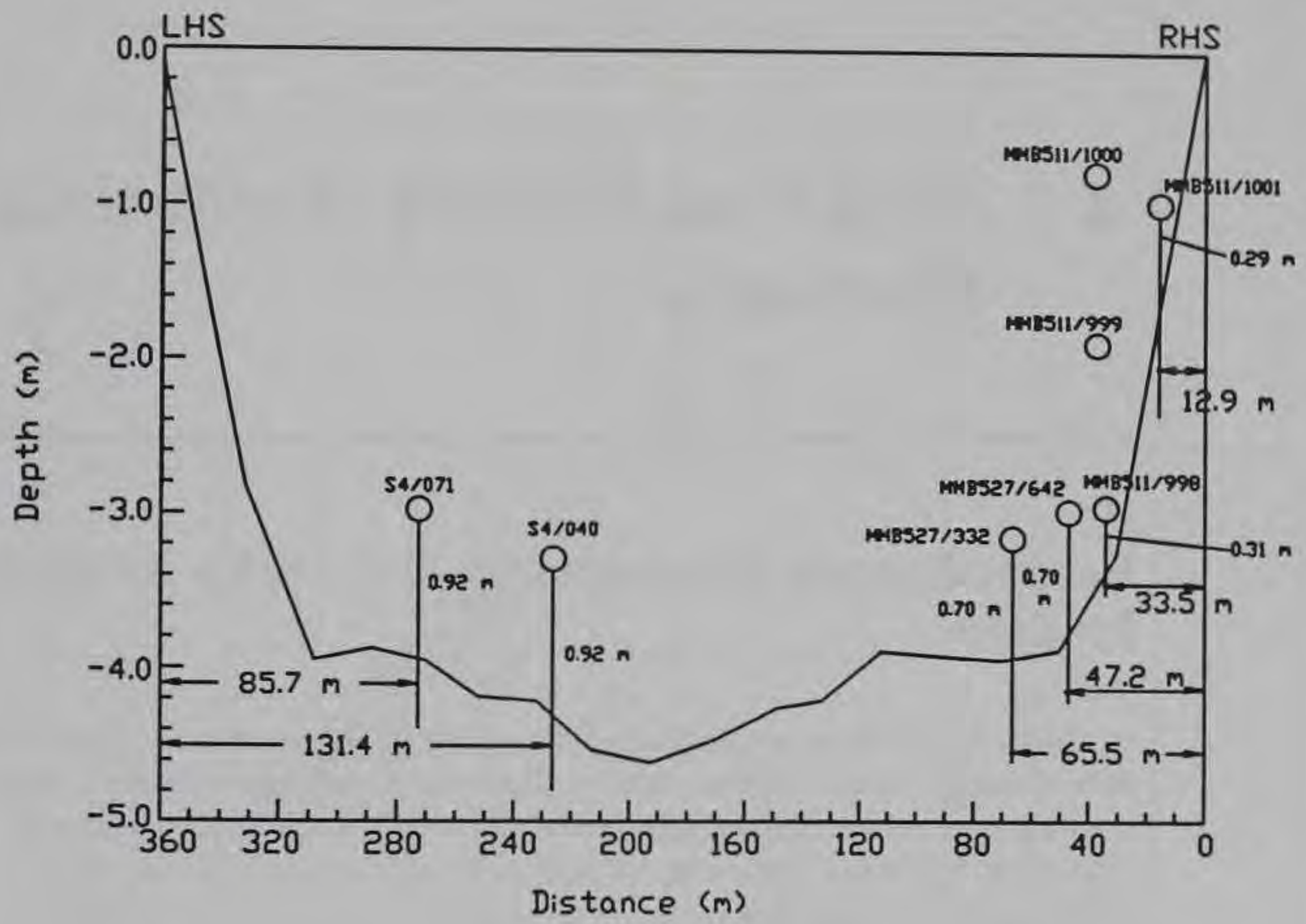

Note: Meters 998, 999, and 1000 are mounted on a platform at $0.31,1.22$, and $2.44 \mathrm{~m}$ above the bottom, respectively. The velocity meters are two dimensional electromagnetic meters. Details of the meter descriptions can be found in Bhowmik, Soong, and Xia (1993a).

Figure 2. Cross section of the Illinois River at the Kampsville site for trip 1 


\section{1 and 1995 Analytical Methods}

\section{Return Current Comparisons with 1991 Analytical Method}

Tow speed used in application of the analytical methods was equal to the sum of vessel speed relative to the ground and the ambient velocity. Ambient velocity was positive for unbound tows and negative for downbound tows. Data were limited to tows with a length at least 40 percent of the channel width to eliminate the tow length effects measured in physical model tests of the Clark's Ferry reach being studied on the Mississippi River (Maynord and Martin 1996b).

A scatterplot of observed return velocity versus the predicted return velocity using the 1991 analytical method (Figure 3) was developed from the Kampsville physical model data. The 1991 analytical method under predicts return velocity observed in the physical model for most of the tests.

Comparison of the 1991 analytical method to the ISWS data required determining the draft, beam, and length to use for some unusual tow configurations having a mixture of loaded, unloaded, and partially loaded barges. The approach for this report selected the beam, draft, and length of the section having the maximum cross-sectional area.

A scatterplot (Figure 4) of observed prototype return velocity versus the predicted return velocity from the 1991 analytical method was developed from ISWS Kampsville prototype test data. As in the physical model, prototype data were limited to tows with a length greater than 40 percent of the channel width. N less than or equal to 51 was used to agree with the limits of the physical model data. Meters 998 and 1001 from trip 1 were excluded because their close proximity to the boundary $(0.31 \mathrm{~m})$ led to boundary layer effects. As in the physical model, the 1991 analytical method under predicts observed prototype return velocity for most tests. 


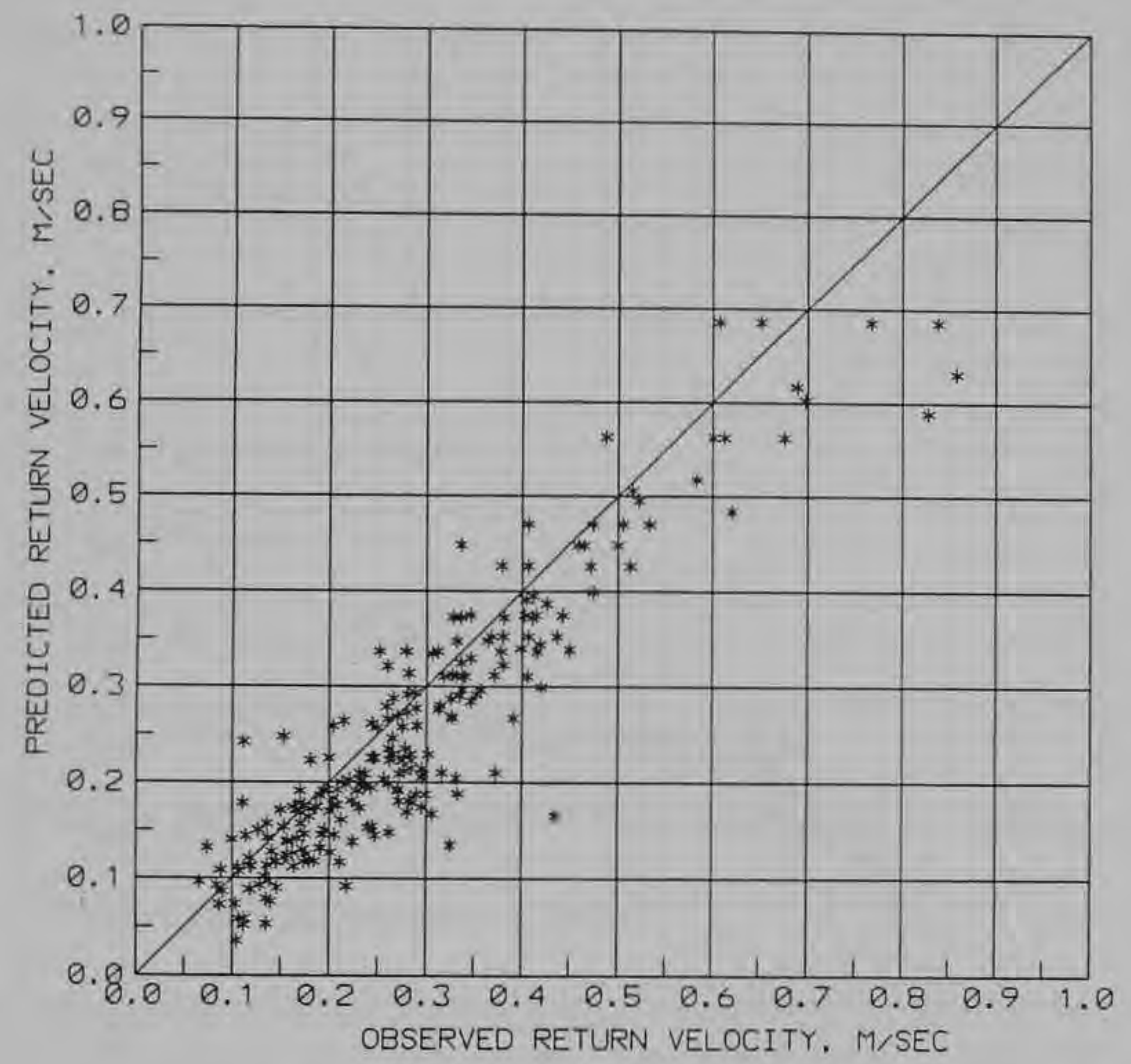

Figure 3. Observed physical model return velocity versus computed return velocity using 1991 analytical method

\section{Analytical Method}

Based on the underprediction of both physical model and prototype results, the 1991 analytical method must be reexamined. The physical model data from Kampsville and Clark's Ferry provided an opportunity to evaluate each part of the 1991 method. The maximum return velocity $V_{r}(Y)$ during the tow event for each meter is the value extracted from the model and prototype data. The $V_{r}(Y)$ data from the eight physical model meters from the Kampsville and Clark's Ferry physical model data were averaged to determine the return velocity representative of the entire cross section $V_{r}$. Since $V_{r}(Y)$ is the maximum return velocity during the tow event at $Y, V$, is a cross-sectional average of these maximums. The ratio $\mathrm{Vr} / \mathrm{Schijf} \mathrm{Vr}$ (from Eq's 1 and 2) was compared for upbound versus downbound vessels to determine if the average channel velocity is the correct velocity to use in determining the velocity of the tow relative to the water. A likely alternative is the velocity where the tow is operating which is generally greater than the average channel velocity. 


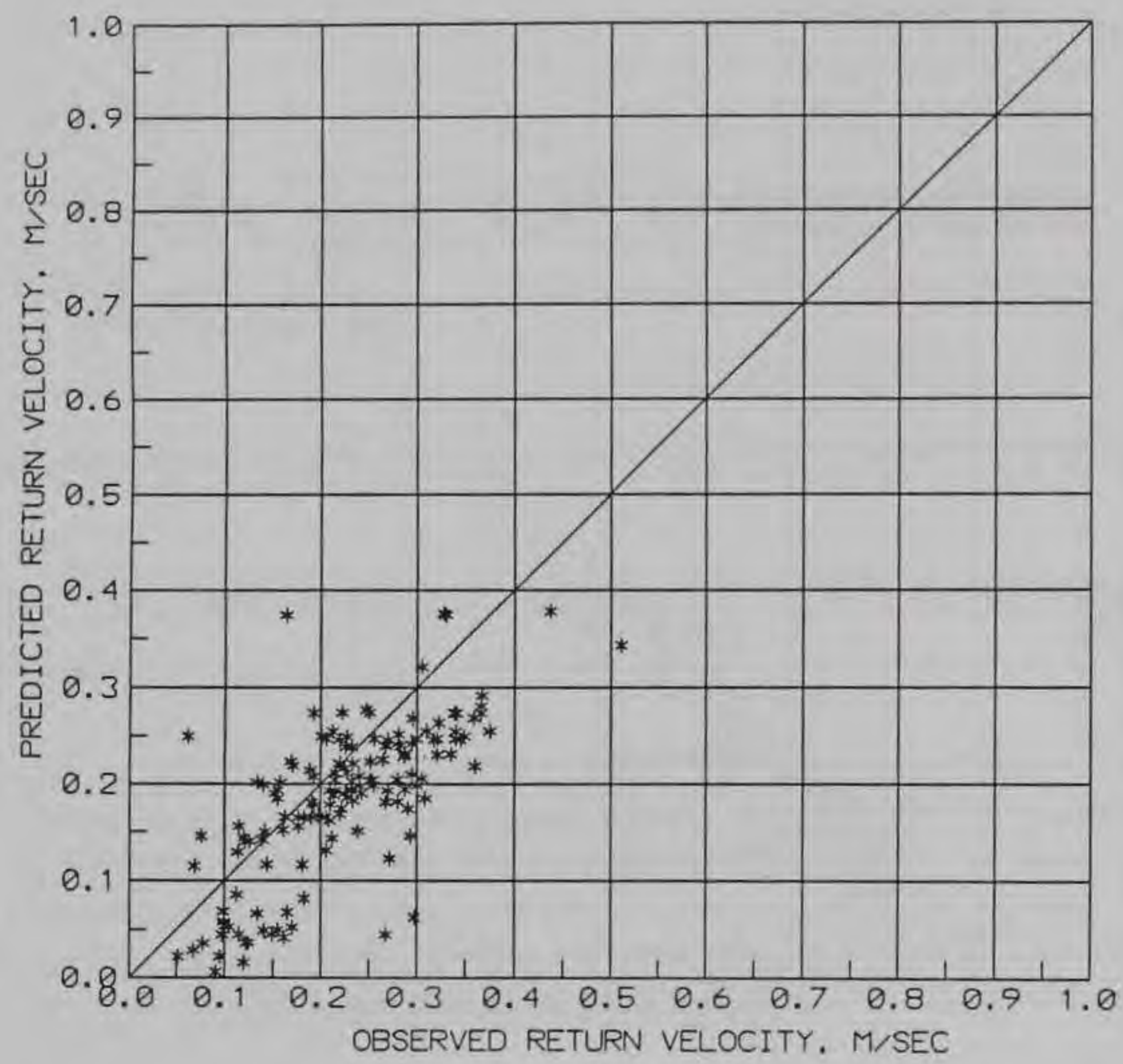

Figure 4. Observed prototype return velocity versus computed return velocity using 1991 analytical method

The average $\mathrm{Vr} / \mathrm{Schijf} \mathrm{Vr}$ for upbound tows was higher than the average ratio for downbound tows when using the average channel velocity to determine the vessel speed through the water. When the average channel velocity was increased by 20 percent and then used to determine the speed through the water, upbound and downbound tows gave the same average ratio. This finding tends to confirm the use of the velocity where the tow operates when determining the tow speed through the water. The 20 -percent increase is consistent with the actual velocity that occurs in the deeper areas where the tow is operating

The Schijf return velocity, calculated using Equations 1 and 2 with the 20-percent increase in Vavg, under predicted the observed cross-sectional average of the maximum $V r$ from the physical model. To correct this underprediction, an effective draft and beam were determined by adding the displacement thickness to the draft and twice the displacement thickness to the beam of the vessel as recommended by Gates and Herbich (1977). Displacement thickness is determined from the Prandtl-Schlicting skin friction 
equation for a smooth flat plate at zero incidence (Schlicting 1968). Displacement thickness $\delta_{I}$ is determined from the skin friction equation according to

$$
\delta_{1}=\frac{0.292 L}{\left(\log \left(R_{L}\right)\right)^{2.58}}
$$

where

$$
\begin{aligned}
L & =\text { total barge length } \\
R_{L} & =\mathrm{V}_{\text {disp }} \mathrm{L} / \mathrm{v} \\
V_{\text {disp }} & =\mathrm{V}_{\mathrm{g}}+\mathrm{V}_{\text {amb }}+\text { Schijf } \mathrm{Vr} \\
V_{g} & =\text { vessel speed over the ground } \\
V_{a m h} & =\text { positive for upbound tows and negative for downbound tows } \\
\nu & =\text { kinematic viscosity of water }
\end{aligned}
$$

While this significantly improved the comparison between observed average $V_{r}$ and $V_{r}$ (Schijf), the error between the two was a function of the ratio of vessel speed to the critical or limiting speed $\left(V_{L}\right)$ from Equations $I$ and 2 . Dependence with $V / V_{L}$ is consistent with the findings of Schijf (1949). The observed physical model data were used to develop a correction factor based on $V / V_{L}$ which provided good agreement between observed average $V_{r}$ and Schijf $V_{r}$. Schijf $V_{r}$ is calculated using the effective draft and beam in the Schijf equation. Average $V_{r}$ is calculated from

$$
V_{,}=V_{r}(\text { Schijf })\left(1.9-1.29 V / V_{L}\right)
$$

The computed $V_{r}$ from Equation 13 is not allowed to be less than the return velocity from the Schijf equation and $V / V L$ should be from 0.35 to 0.9 . The comparison between observed $V$, from the Kampsville and Clark's Ferry physical models and computed $V$, using Equation 13 is shown in Figure 5. Since $\delta_{1}$ is computed using $V_{r}$ from equations 1 and 2 , the solution does not require iteration with Equation 13.

The next step is evaluating the relationship in Equation 8 that proportions the return velocity on each side of the vessel. The return velocity for each side of the vessel $V_{r s}$ was determined for each test using the Kampsville and Clark's Ferry physical model data. $V_{r s}$ was normalized by the observed 


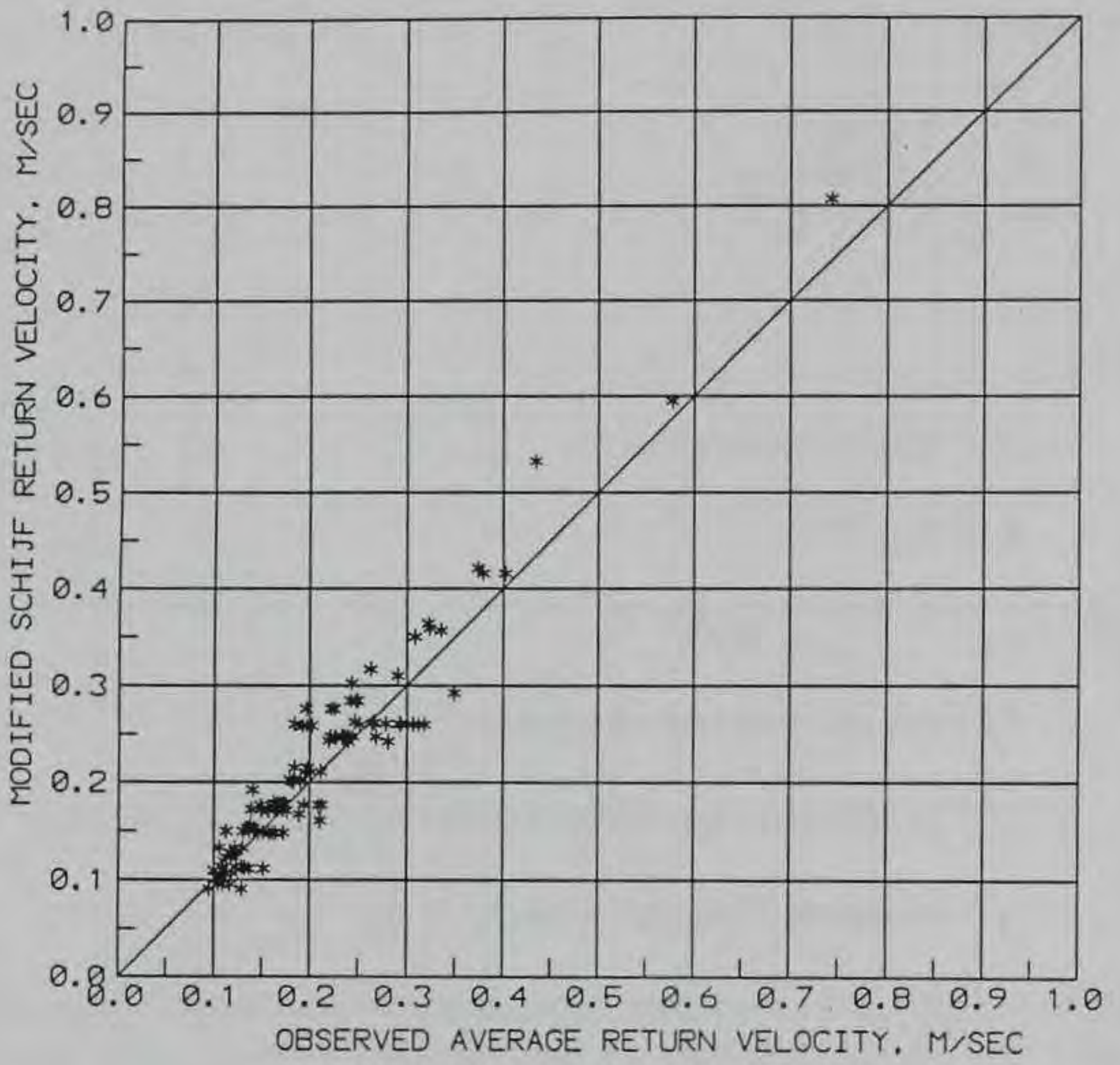

Figure 5. Observed physical model average return velocity versus computed Schijf return velocity

average $V_{r}$ (which represents the entire cross section) and tested against various parameters such as SKEW used in Equation 8. The best fit was found using the relation between distance from vessel to shoreline $B_{\text {side }}$ and total channel width $B_{\text {total }}$. For $B_{\text {side }} / B_{\text {total }}$ from 0 to 0.5

$$
\frac{V_{r s}}{\nu_{r}}=1.65-1.3 \frac{B_{\text {side }}}{B_{\text {total }}}
$$

For $B_{\text {side }} / B_{\text {total }}$ from 0.5 to 1.0 


$$
\frac{V_{r s}}{V_{r}}=1.35-0.7 \frac{B_{\text {side }}}{B_{\text {sotal }}}
$$

Equations 14 and 15 are plotted against observed data from the Kampsville and Clark's Ferry physical models in Figure 6 along with rectangular flume data from a previously unpublished data set.

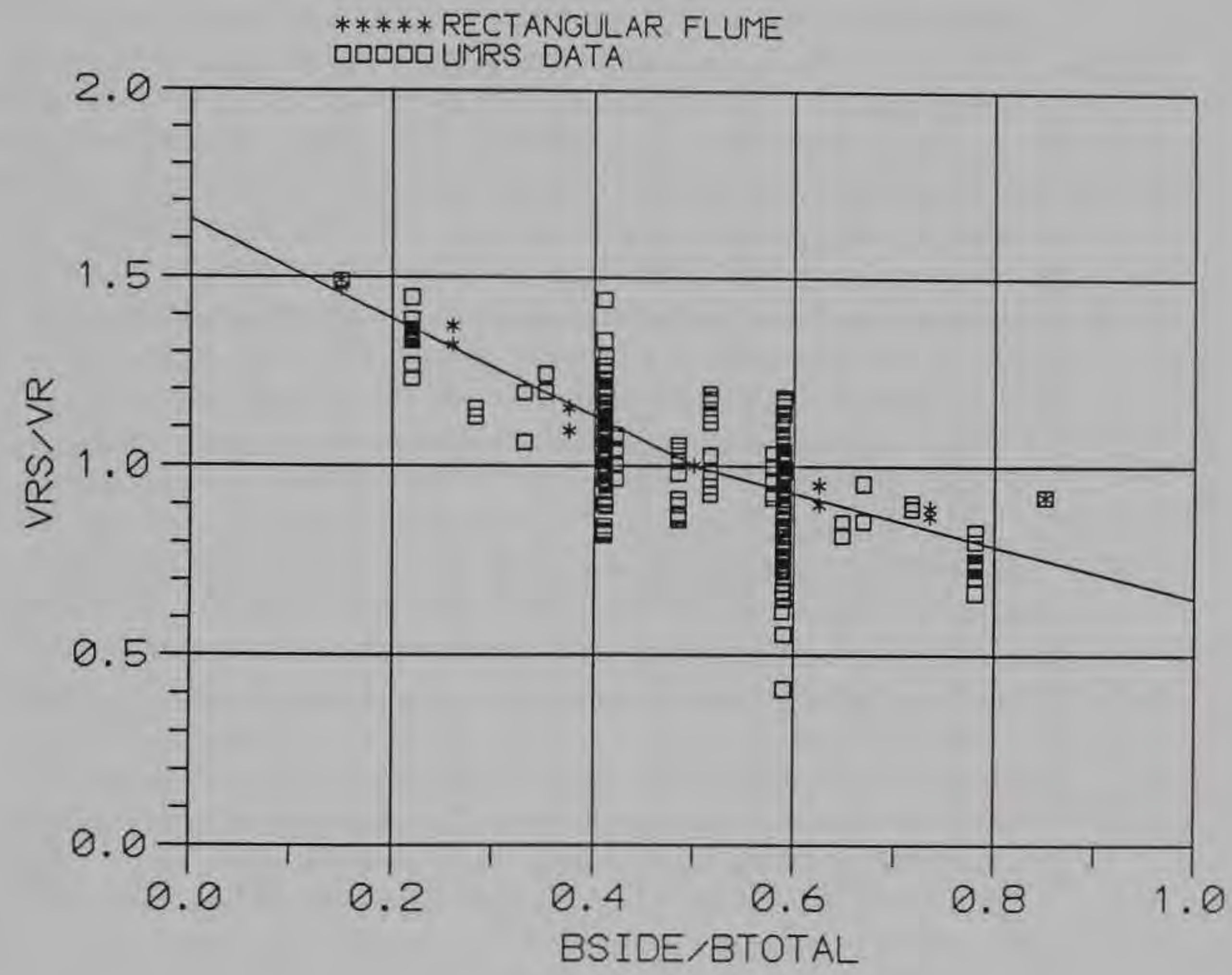

Figure 6. $V_{r s} / V_{r}$ versus $B_{\text {side }} / B_{\text {total }}$ using physical model data

The third step is defining $\alpha^{\prime}=V_{r s m} / V_{r s}$ which defines the uniformity of the return velocity distribution between vessel and shoreline. Previous attempts at this relation using physical model data were only approximate because scale effects were not eliminated from the data as has been done in the Maynord and Martin (1996a,b) physical model data. Only the physical model data from the Kampsville model were used in the analysis of $\alpha^{\prime}$ because of the likely influence of dikes from the Clark's Ferry model. The 
physical model data were used to determine $V_{r s m}$ at $(\mathrm{Y}-\mathrm{B}) /\left(\mathrm{B}_{\text {side }}-\mathrm{B}\right)=0$. Various parameters were tested against $\alpha^{\prime}$, and $N_{\text {side }}$ provided the best agreement with observed data. $V_{r s m} / V_{r s}$ is plotted against $N_{\text {side }}$ in Figure 7 and is described by the equation

$$
\frac{V_{r s m}}{V_{r s}}=\alpha^{\prime}=0.75 N_{\text {side }}^{0.18}
$$

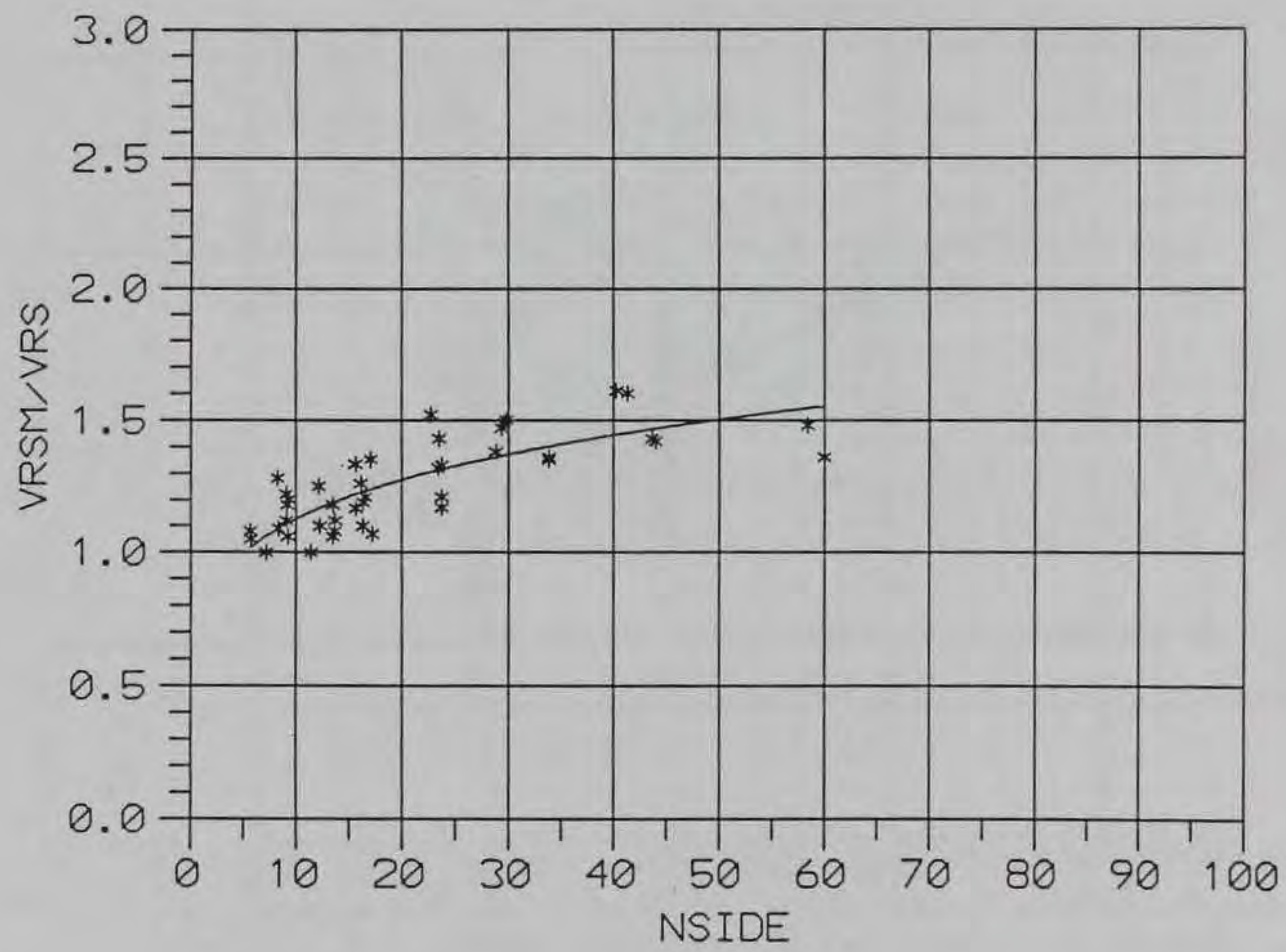

Figure 7. $V_{\text {rsm }} V_{r s}$ versus $N_{\text {side }}$ using physical model data

The final step was determining $C$ in Equation 10 which describes the shape of the return velocity distribution. One requirement of $\mathrm{C}$ is that it must equal zero for $\alpha^{\prime}=1$. The $C$ that best defines the shape of the return velocity distribution in the physical model data from Kampsville and Clark's Ferry is defined by 


$$
C=3.0 \ln \left(1 / \alpha^{\prime}\right)
$$

The revised equations presented above will be referred to hereafter as the 1995 analytical method. A scatterplot of the Kampsville physical model data versus the 1995 analytical method (Figure 8) shows an improved comparison of observed versus predicted return velocity. Individual test plots for the Kampsville physical model are shown in Figures 9 to 13. The six plots on each figure for individual tests having varying speed, position, upbound versus downbound, etc. In the test number, the $\mathrm{K}$ stands for Kampsville and $\mathrm{L}$ or $\mathrm{H}$ for low or high flow. $\mathrm{R}$ or $\mathrm{L}$ stand for right or left of the channel thalweg and $\mathrm{U}$ or $\mathrm{D}$ stand for upbound or downbound. If neither $\mathrm{R}$ or $\mathrm{L}$ appear before $\mathrm{U}$ or $\mathrm{D}$, the tow is on the channel thalweg. The last three numbers give the vessel speed relative to the ground in model meters per second which can be converted to prototype values for the 1:25 Kampsville model by multiplying by $25^{1 / 2}=5$. Details of each test are given in Table 1 . On some of the physical model tests, the exponential type equation given by Equation 10 underpredicts the return velocity at the bank. Other data sets will be examined to see if this trend is repeated. A scatterplot of the Clark's Ferry physical model data versus the 1995 analytical model is shown in Figure 14 for $\mathrm{N}$ less than 52 . Figure 15 provides a scatterplot of tests conducted with pool 572.7 in the Clark's Ferry section which resulted in N of about 85 . The tests in Figure 15 addressed the open river portion of the Upper Mississippi River where large channel cross sections result in large blockage ratios. The 1995 analytical method, derived from physical model data, was then evaluated using the ISWS data. Scatterplots of prototype data from Kampsville and Clark's Ferry are shown in Figures 16 and 17, respectively. Individual plots for the ISWS prototype data at Kampsville are shown in Figures 18 to 21 . Each of the 24 plots in Figures 18 to 21 represent an individual prototype tow with the towboat name given in the upper right-hand corner. Plots where there are two or more points at the same distance from the tow are locations where velocity meters were placed at different vertical positions. Details of the prototype tests are provided in the Table 2 report. Note that the Kampsville prototype data do not show evidence of an increase near the bank. 


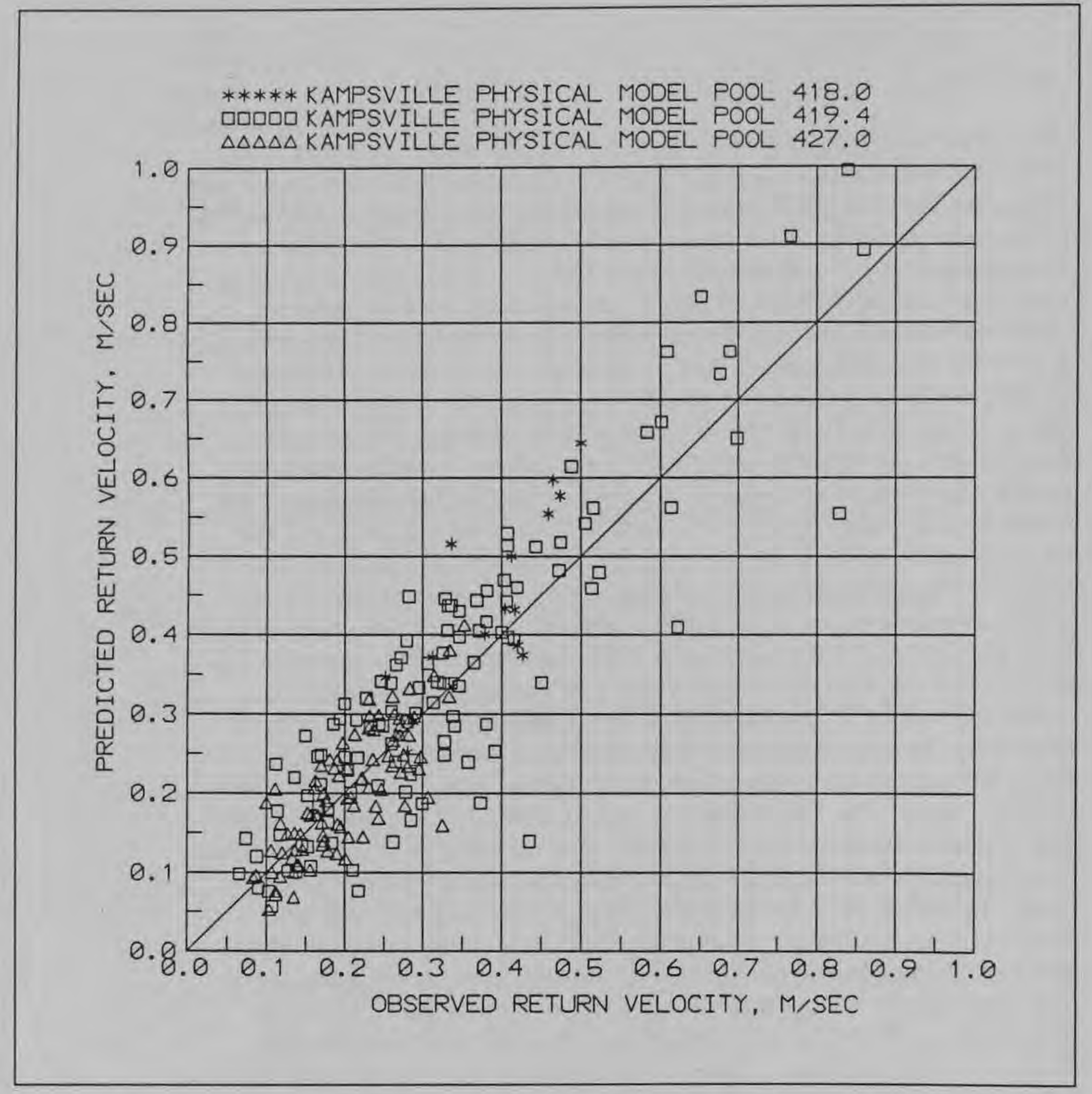

Figure 8. Observed Kampsville physical model return velocity versus computed return velocity using 1995 analytical method 


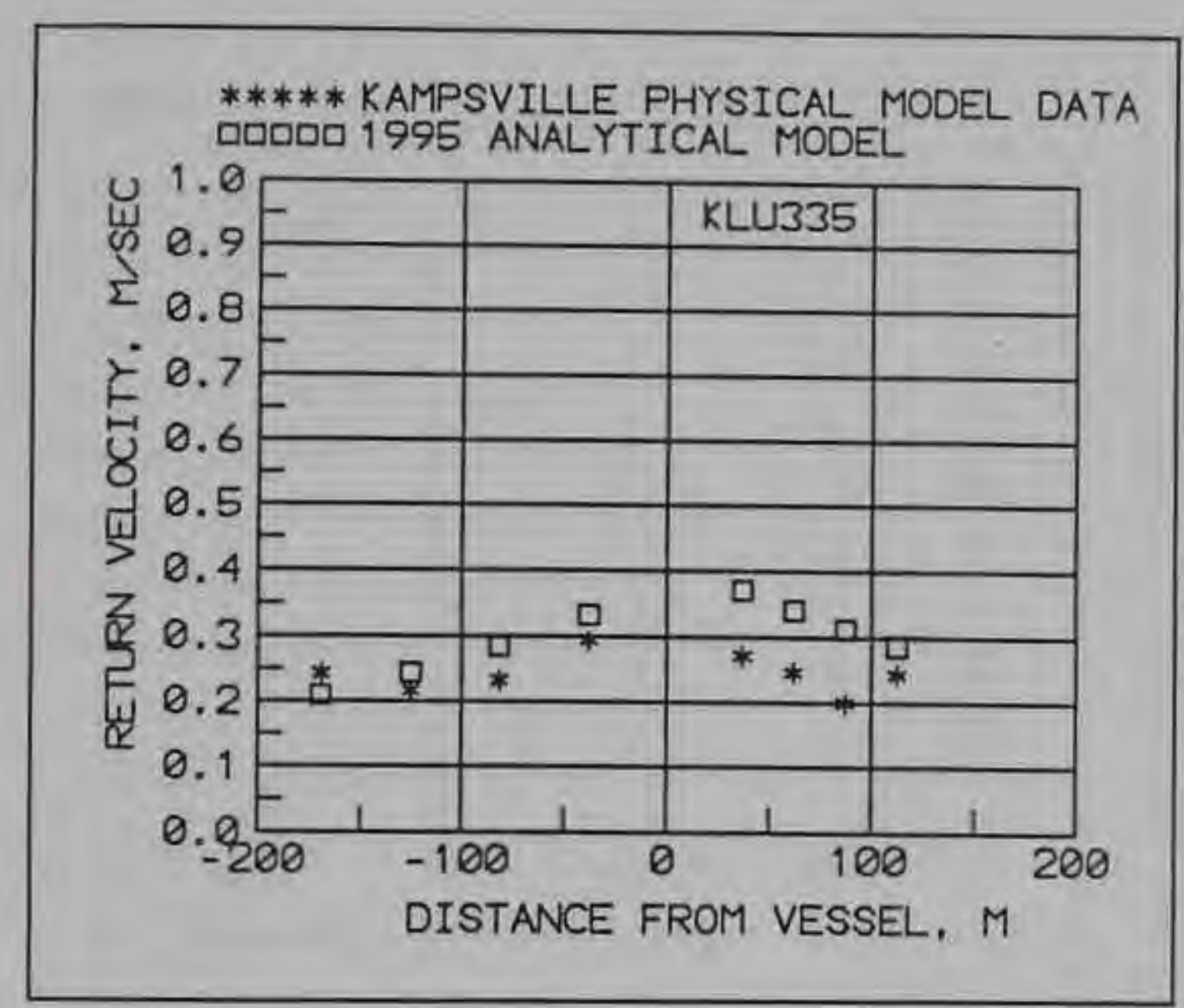

a. Test KLU335

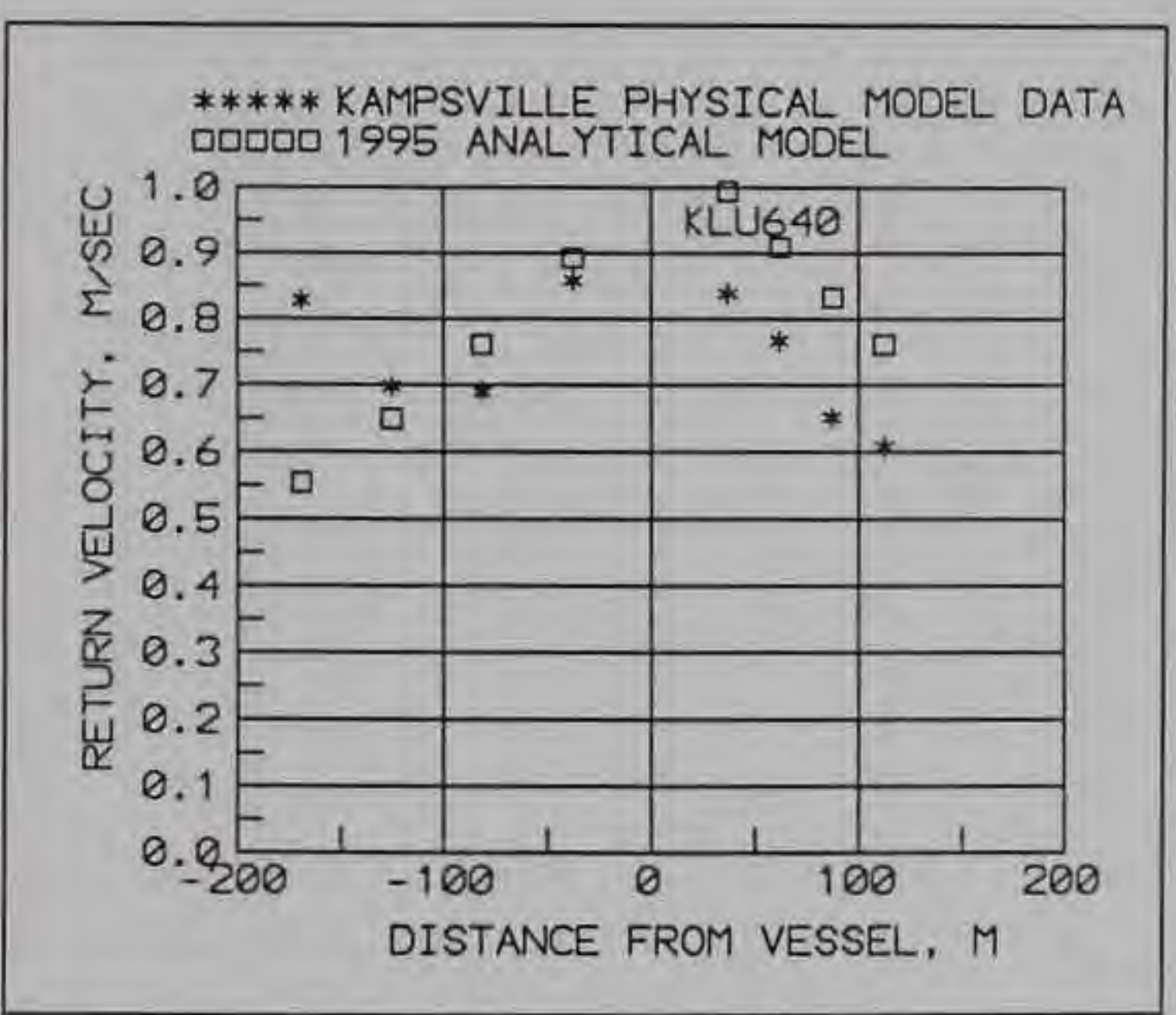

c. Test KLU640

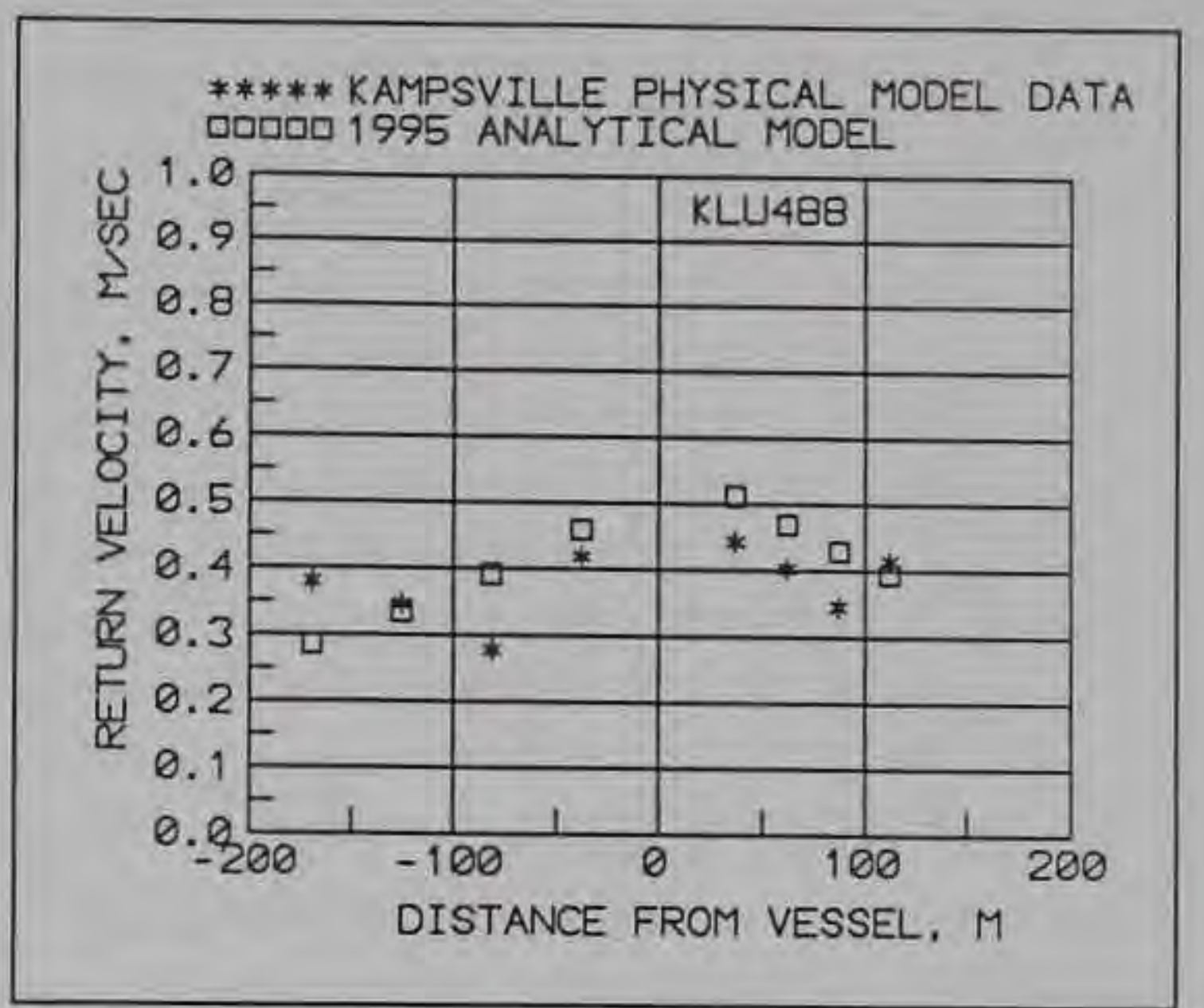

b. Test KLU488

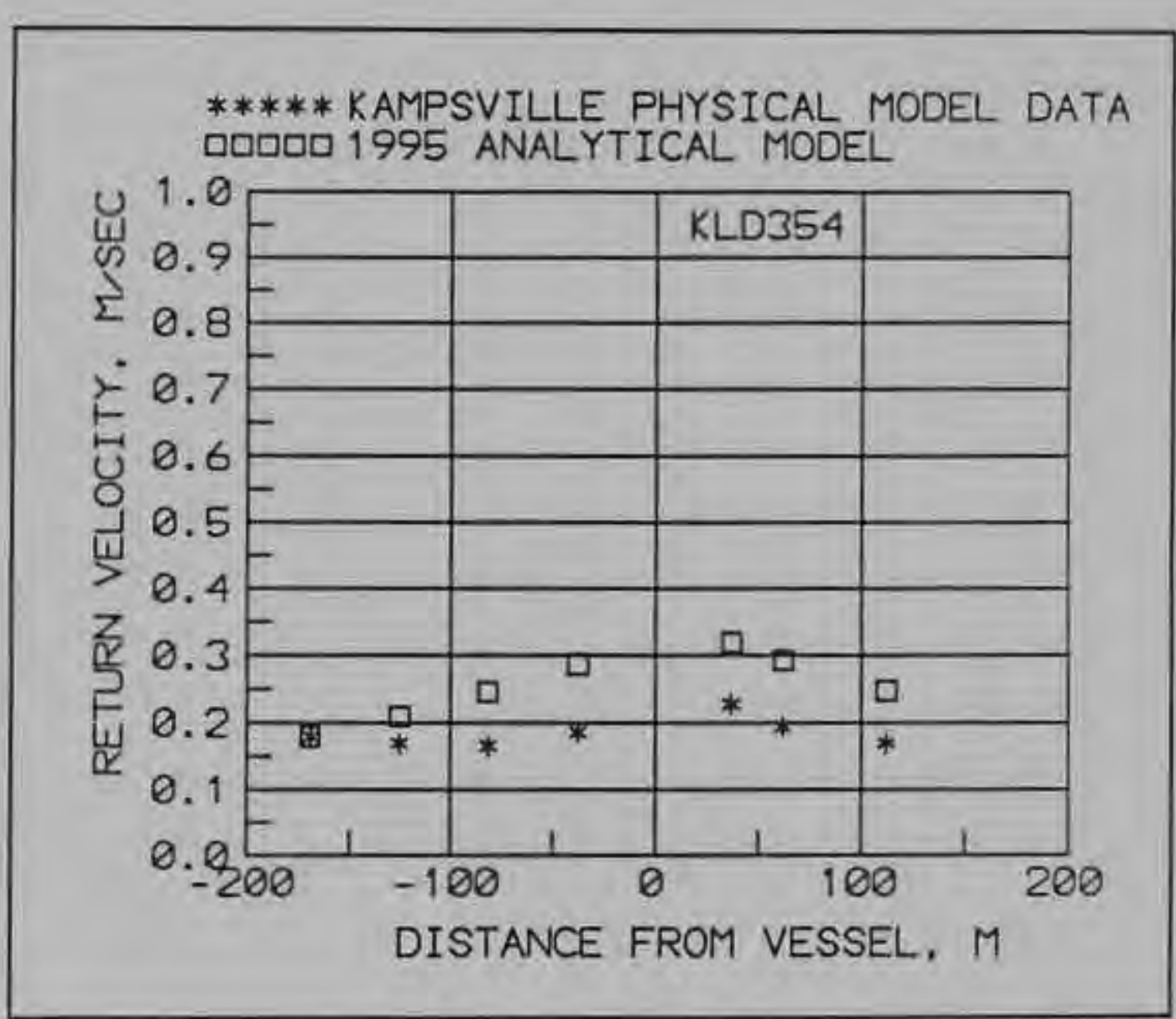

d. Test KLD354

Figure 9. Observed Kampsville physical model return velocity versus computed return velocity using 1995 analytical method for individual tests: KLU335, 488, 640, 354 and KLD506 and 659 (Continued) 


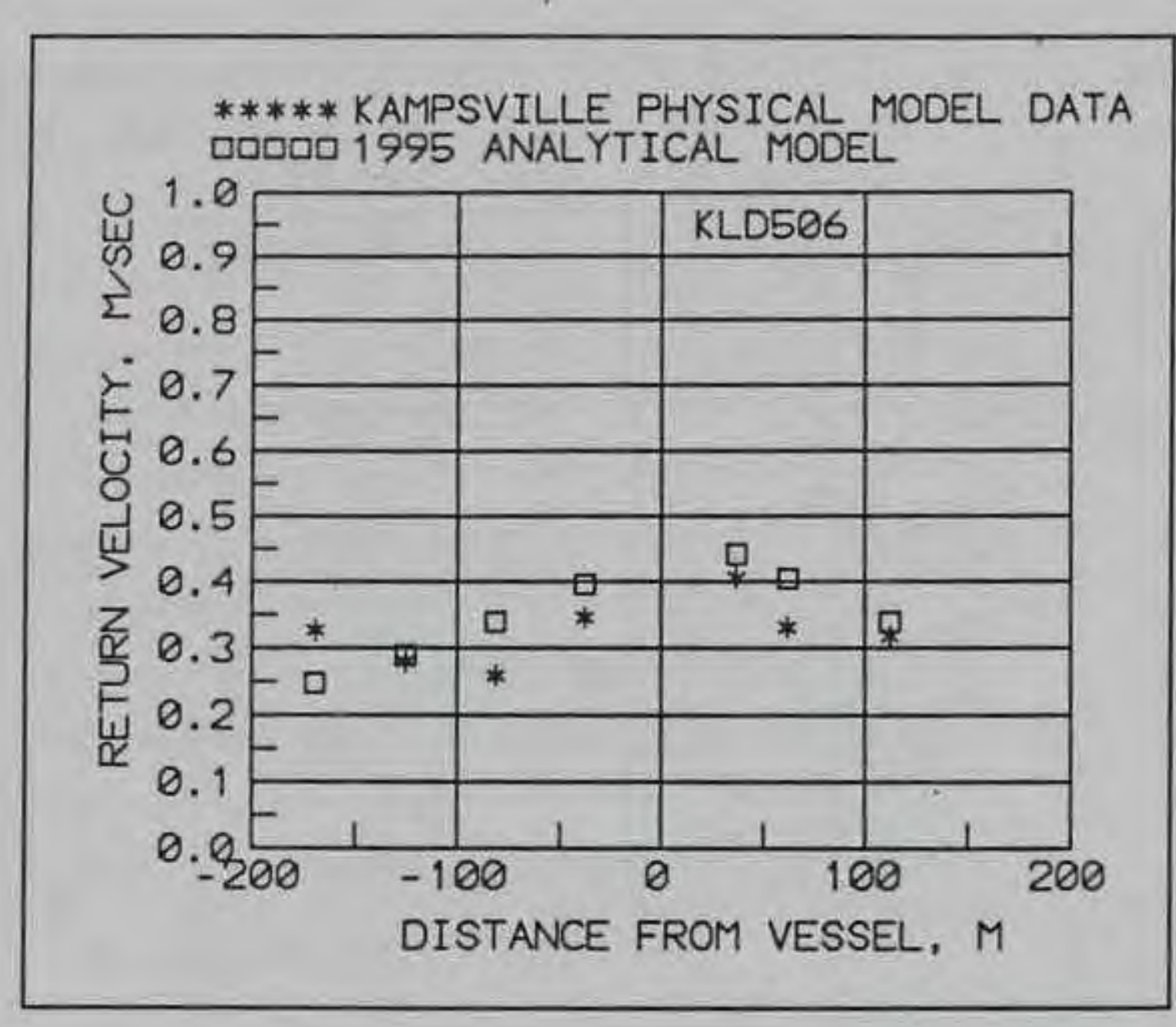

e. Test KLD506

Figure 9. (Concluded)

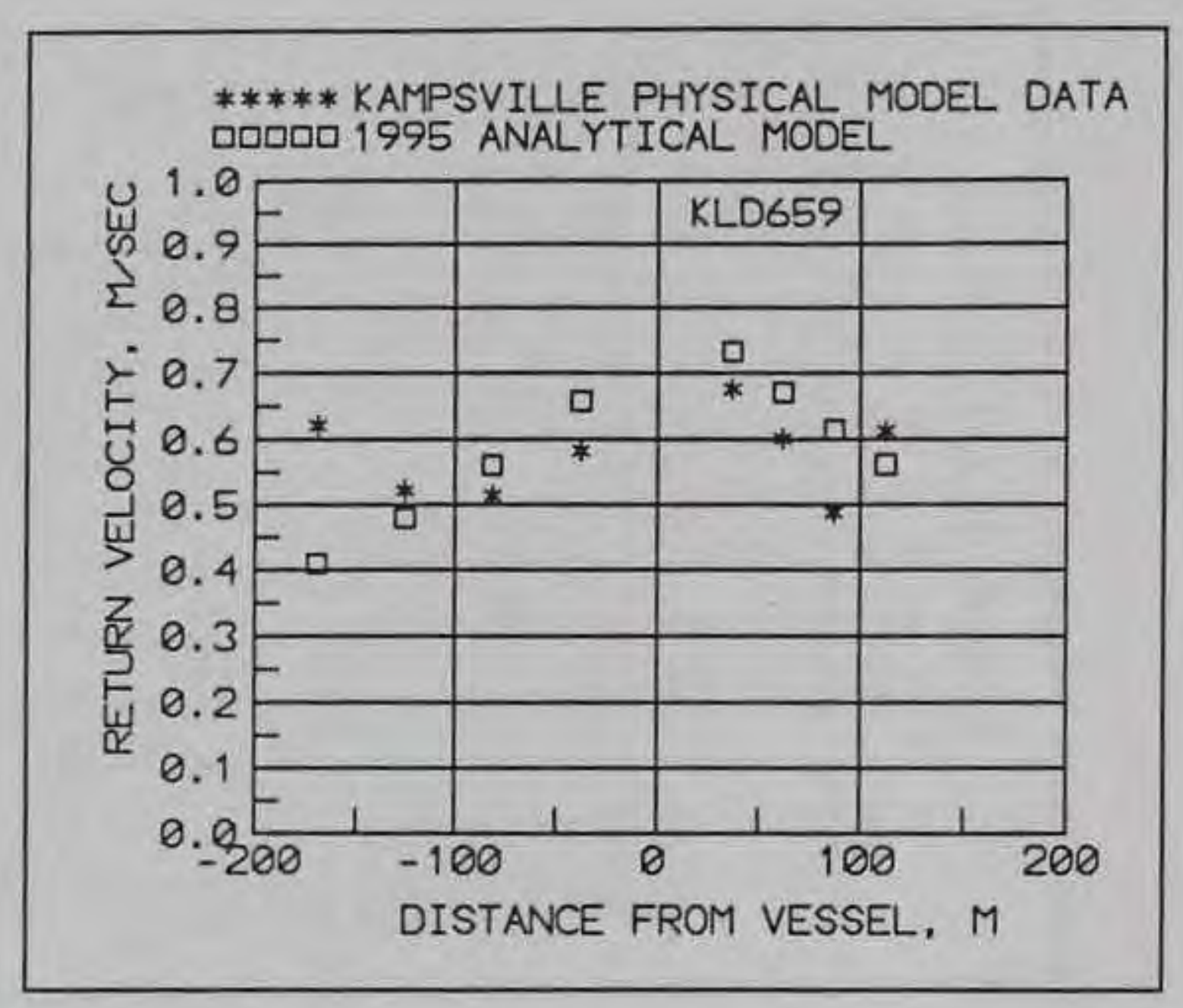

F. Test KLD659 


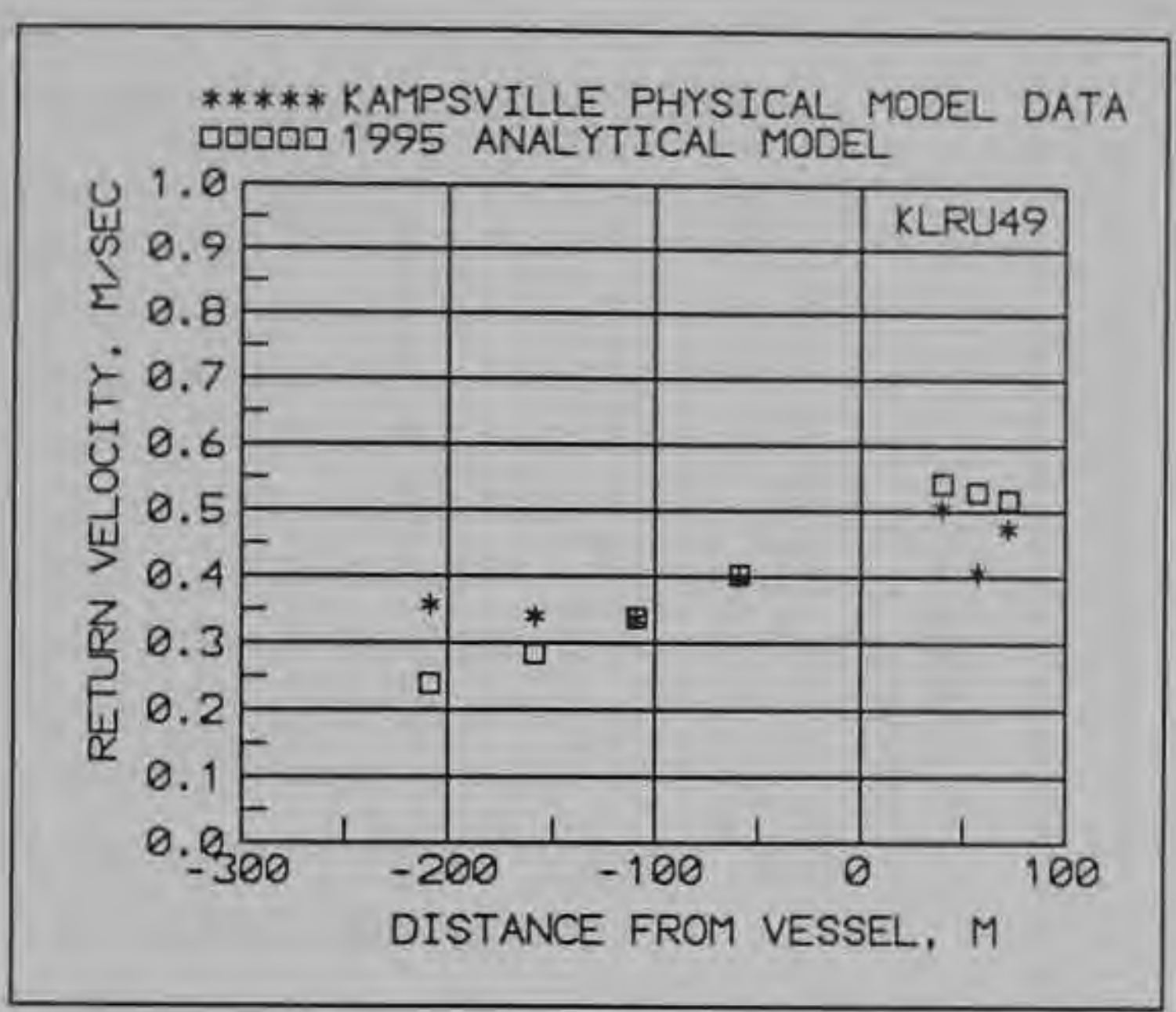

a. Test KLRU49

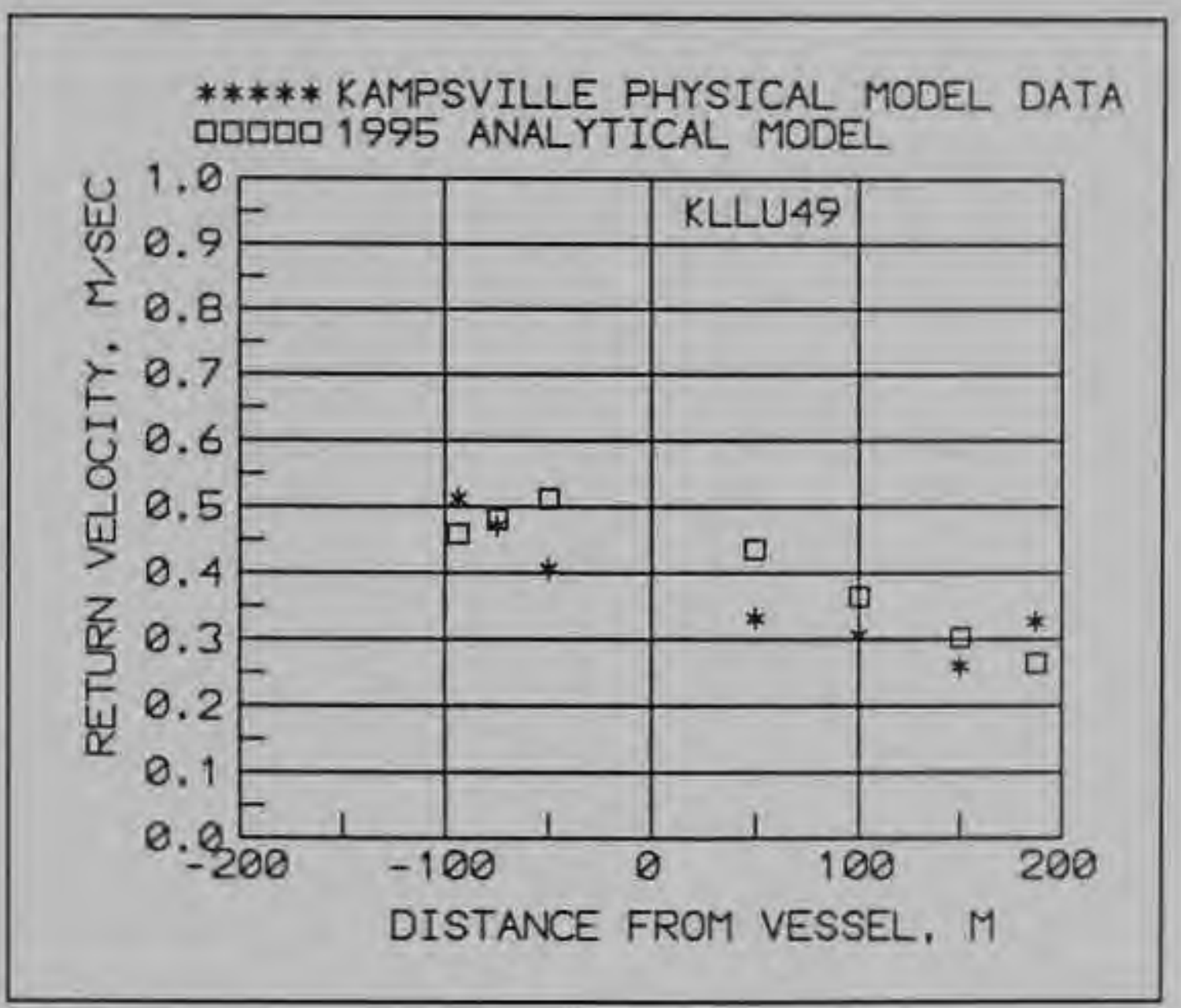

c. Test KLLU49

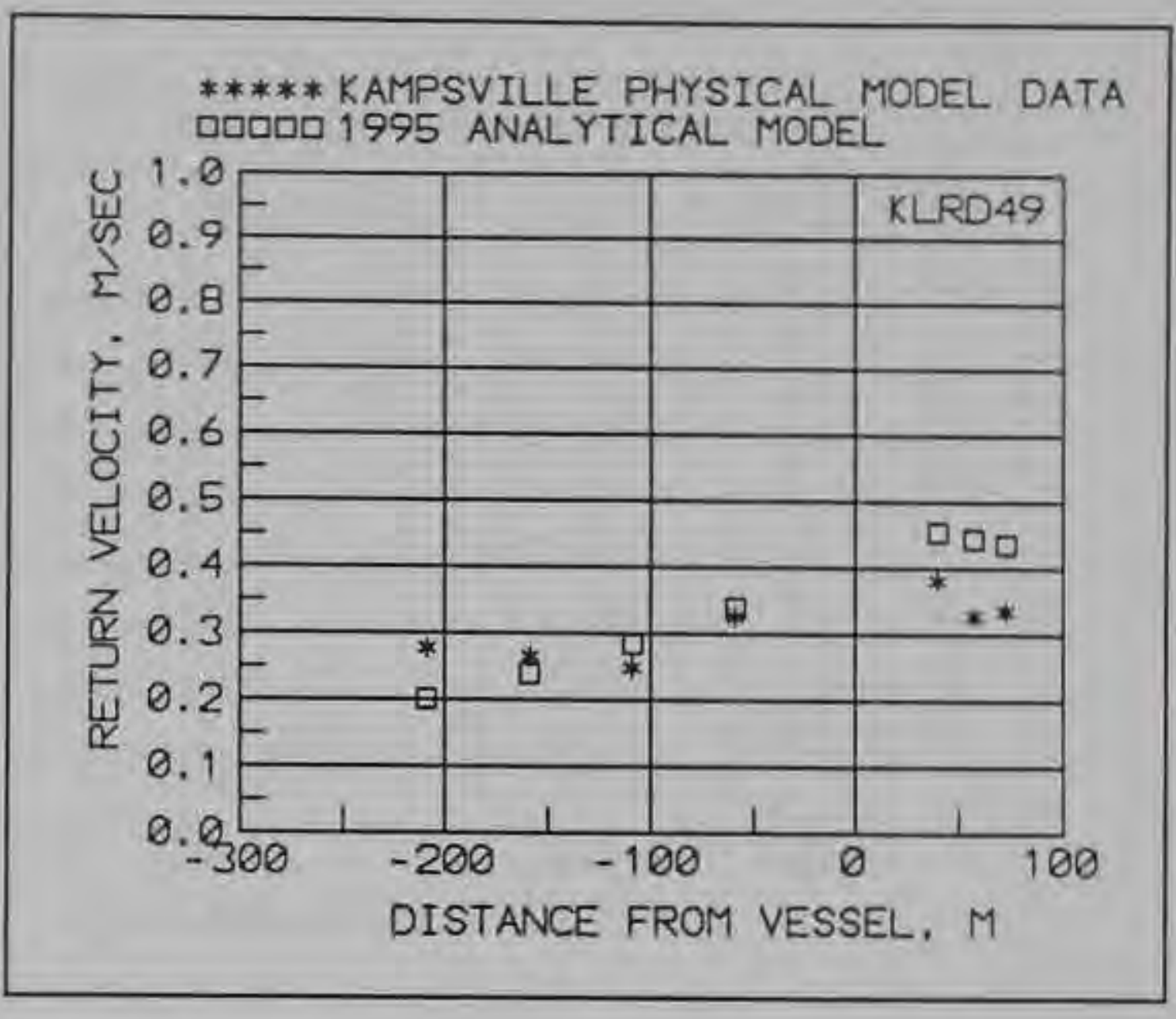

b. Test KLRD49

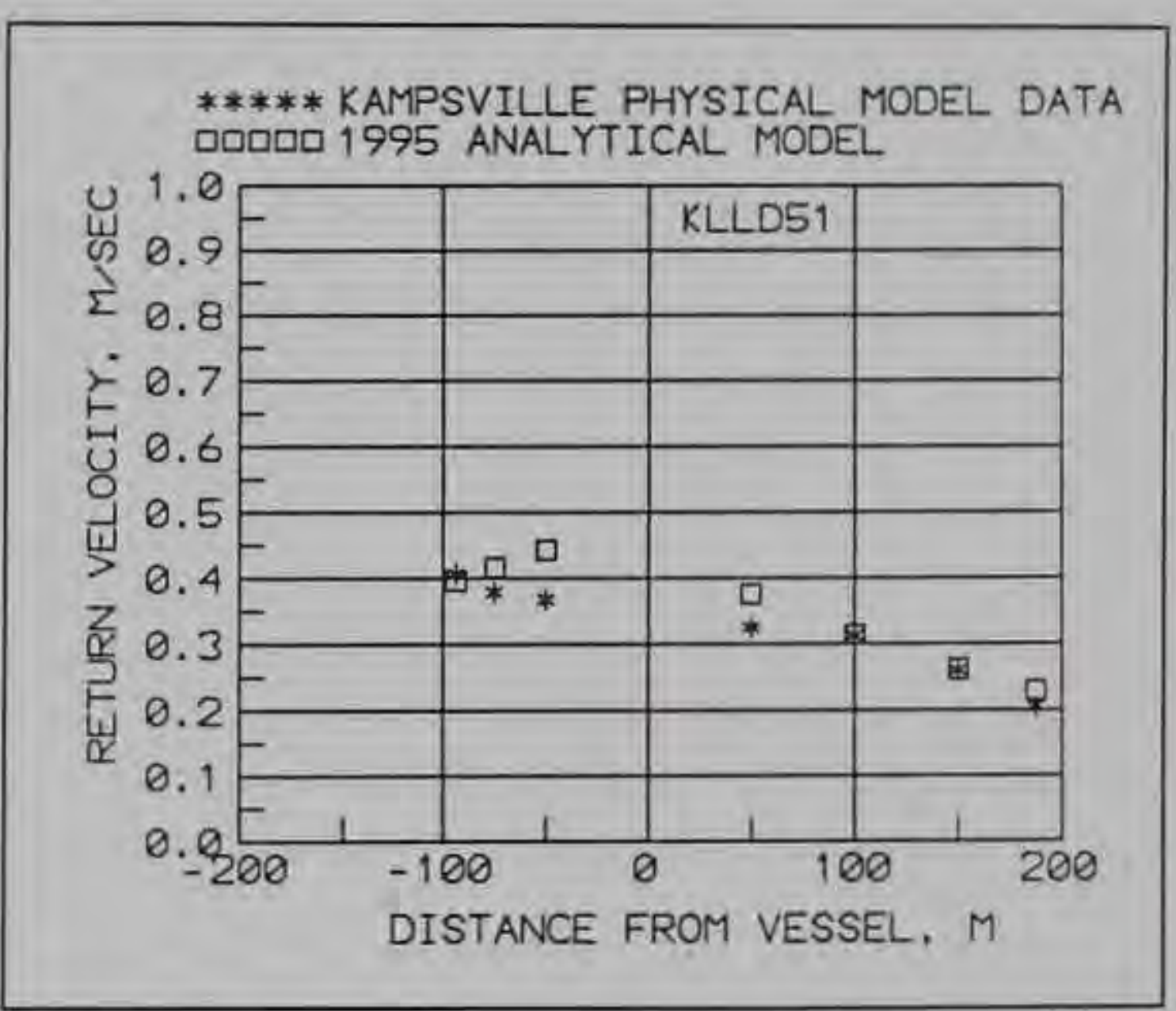

d. Test KLLD51

Figure 10. Observed Kampsville physical model return velocity versus computed return velocity using 1995 analytical method for individual tests: KLRU49, KLRD49, KLLU49, KLLD51, KL1U46, and KL1U61 (Continued) 


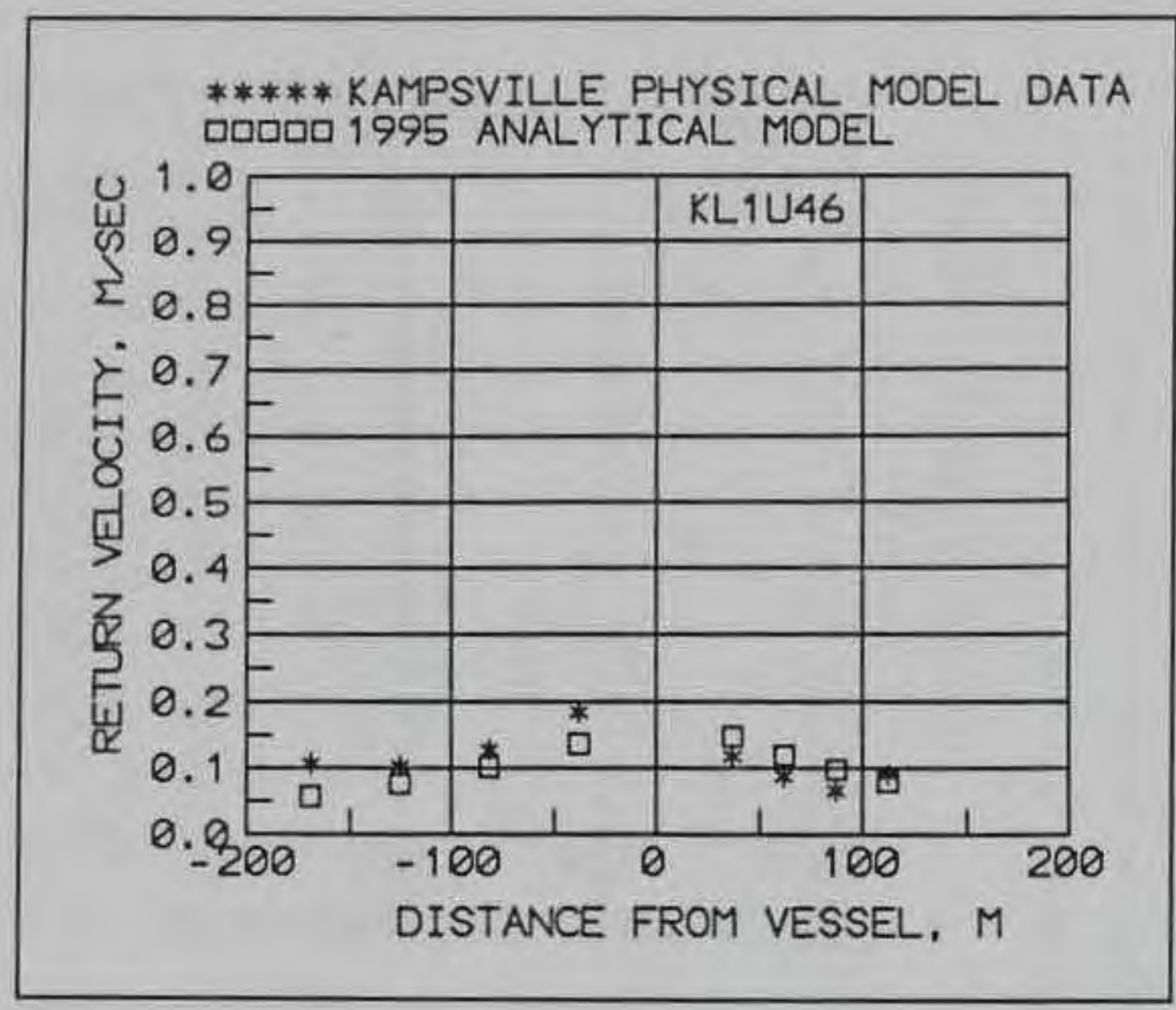

e. Test KL1U46

Figure 10. (Concluded)

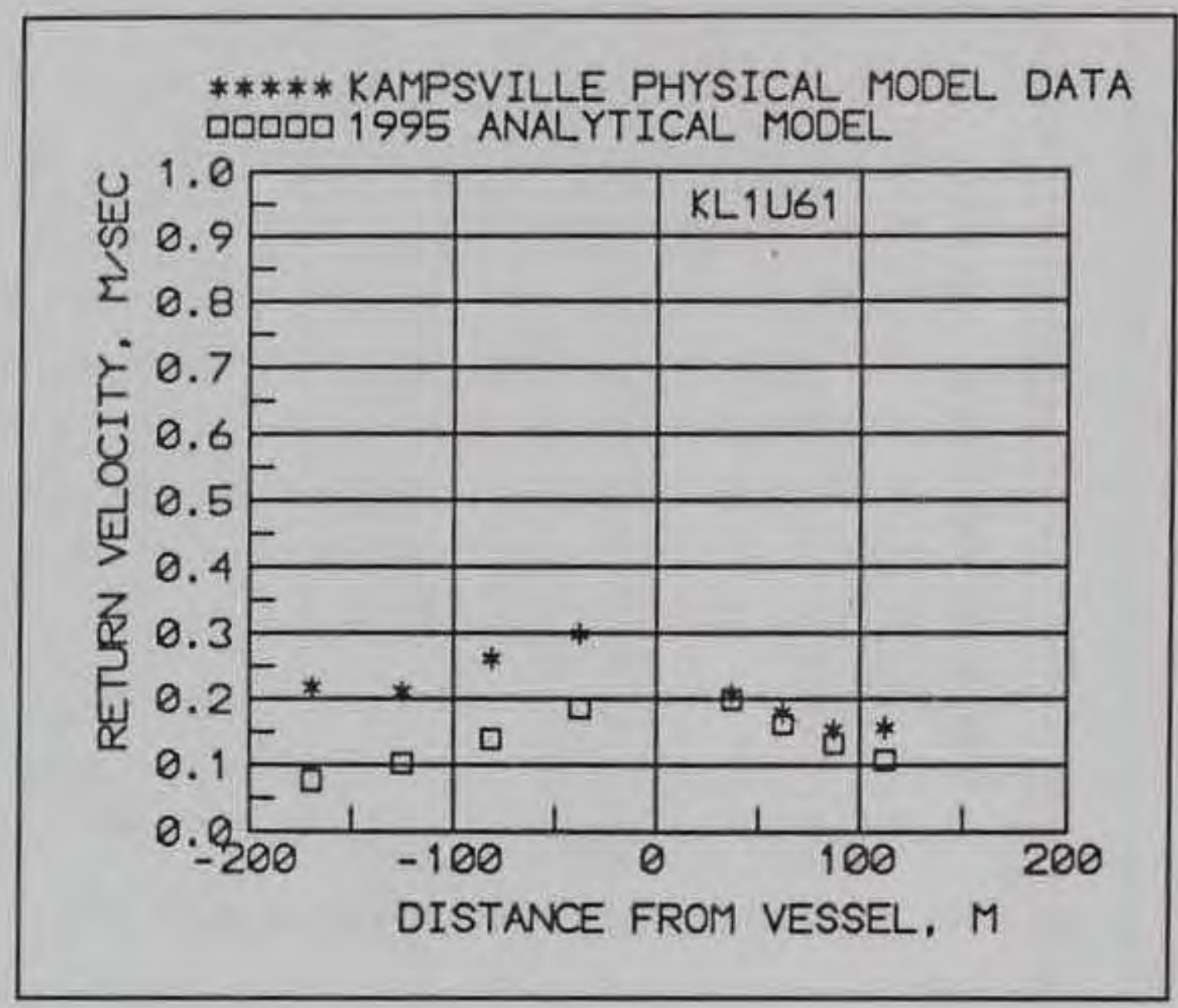

F. Test KL1U61 


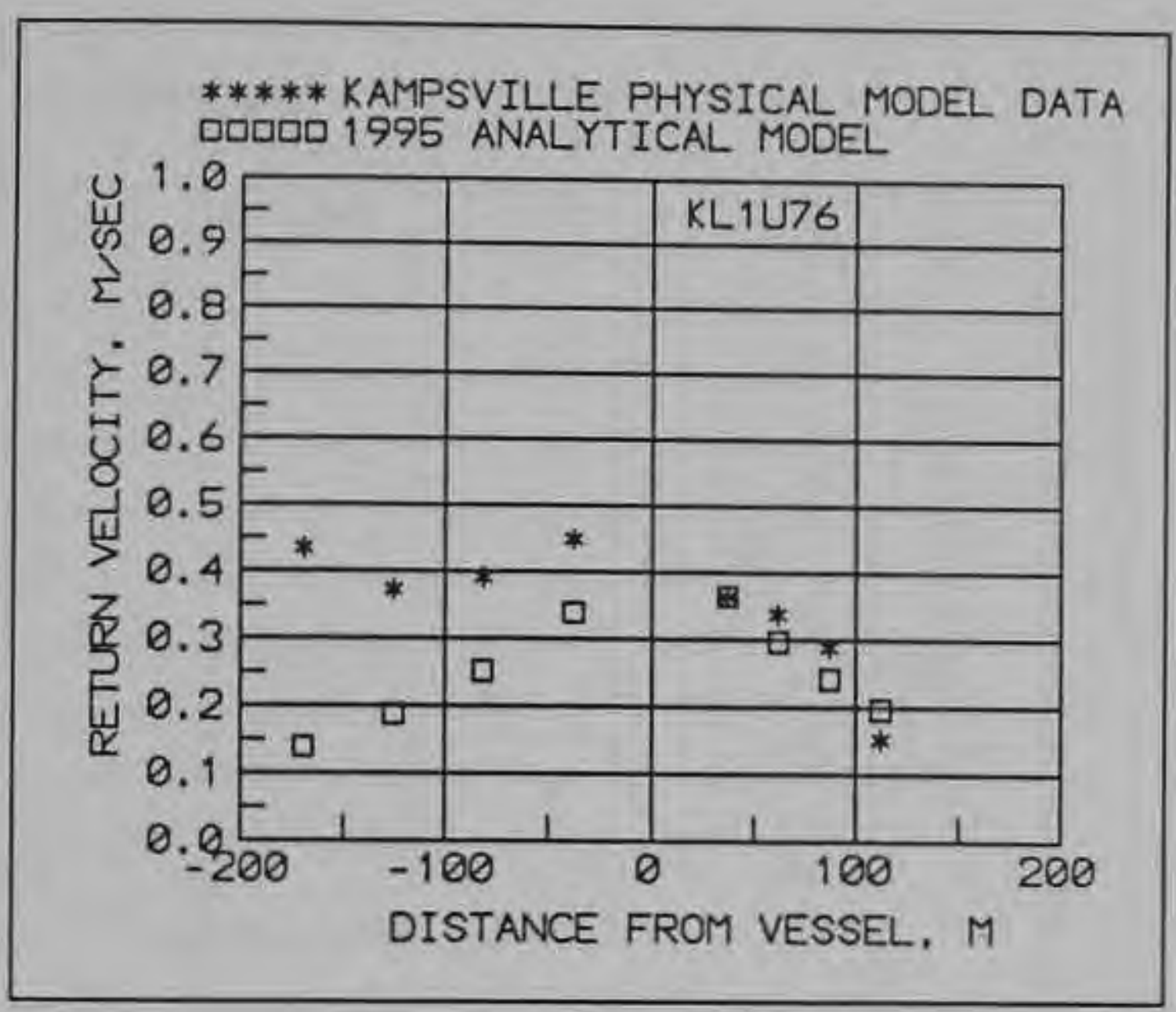

a. Test KL1U76

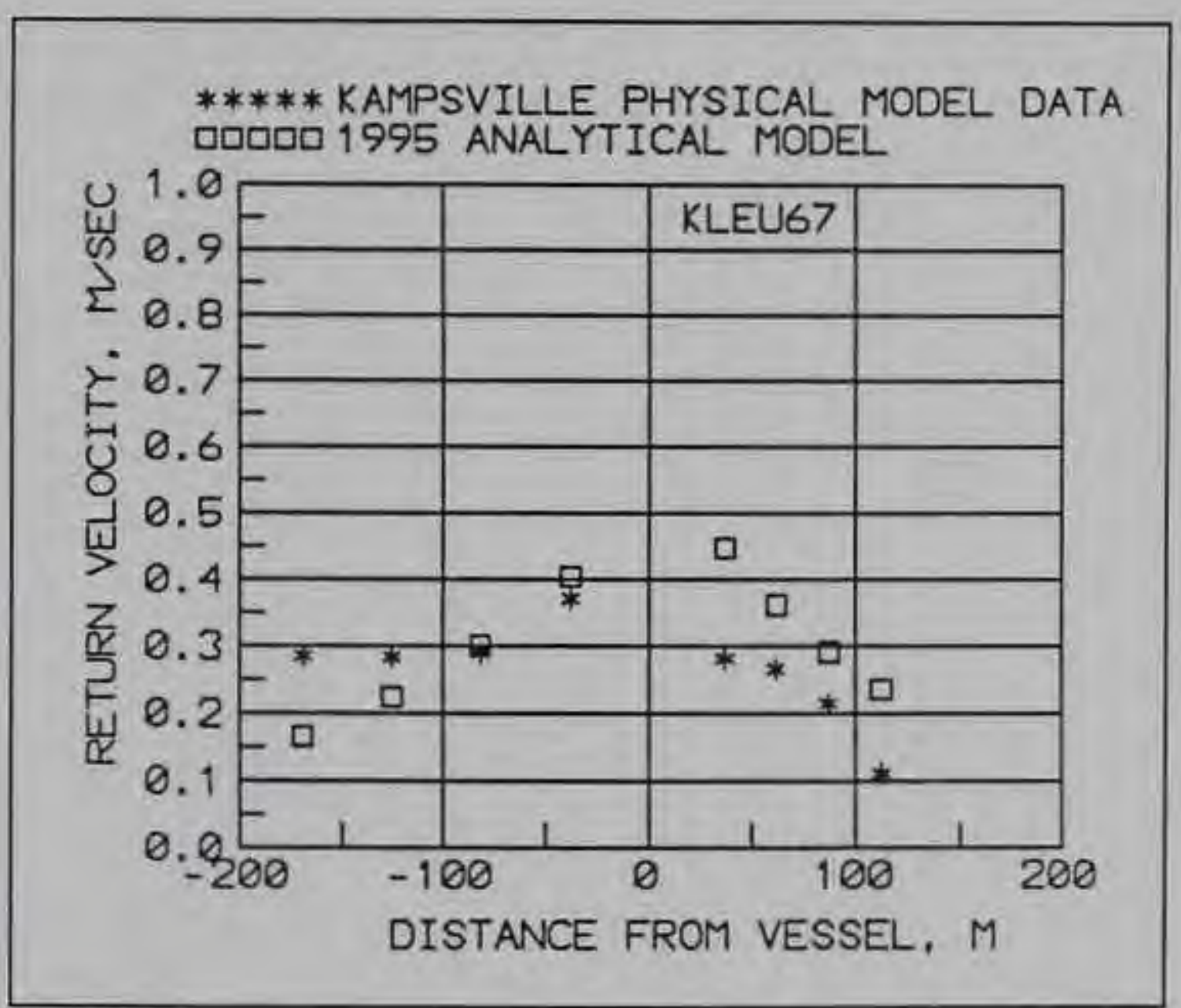

c. Test KLEU67

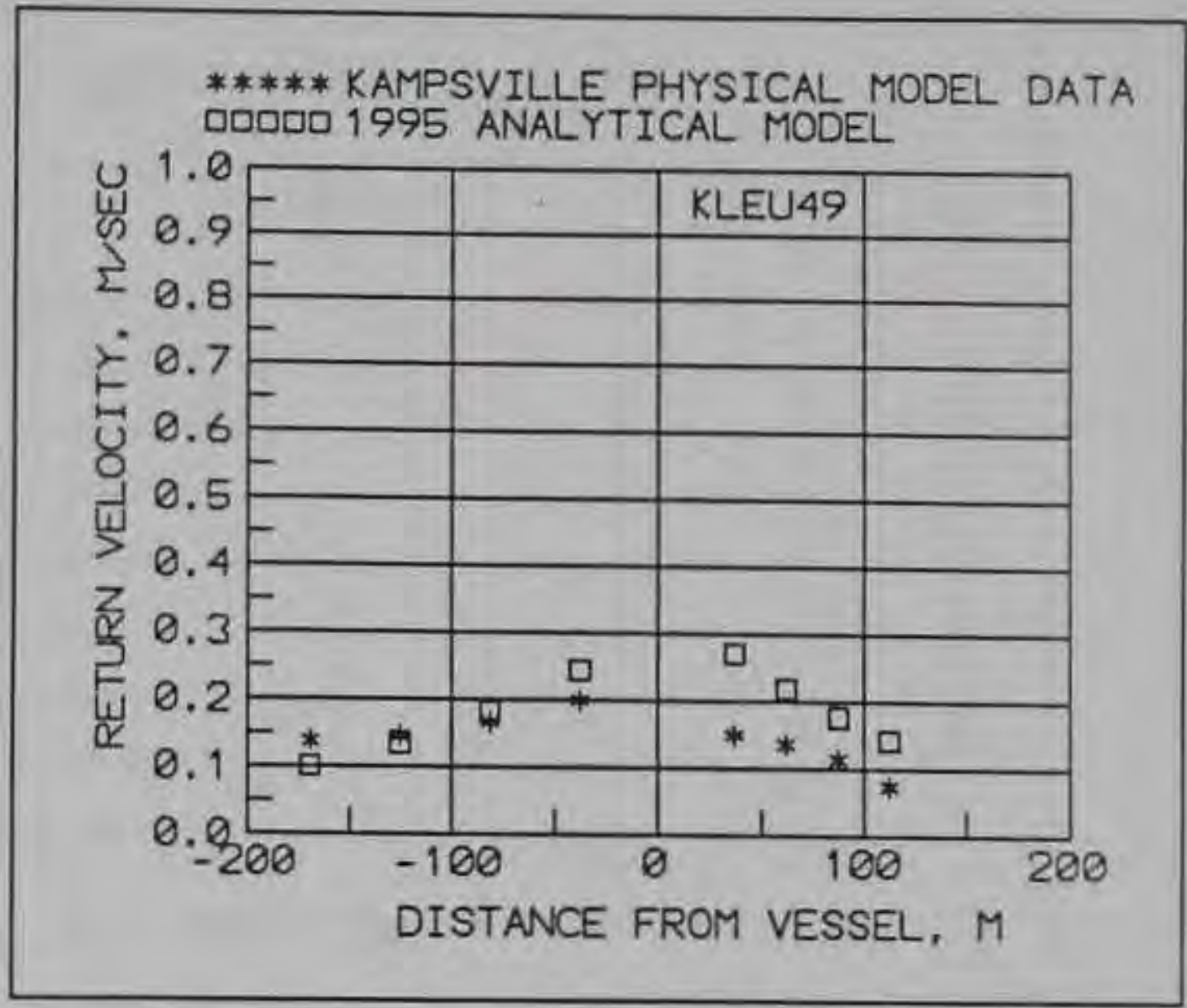

b. Test KLEU49

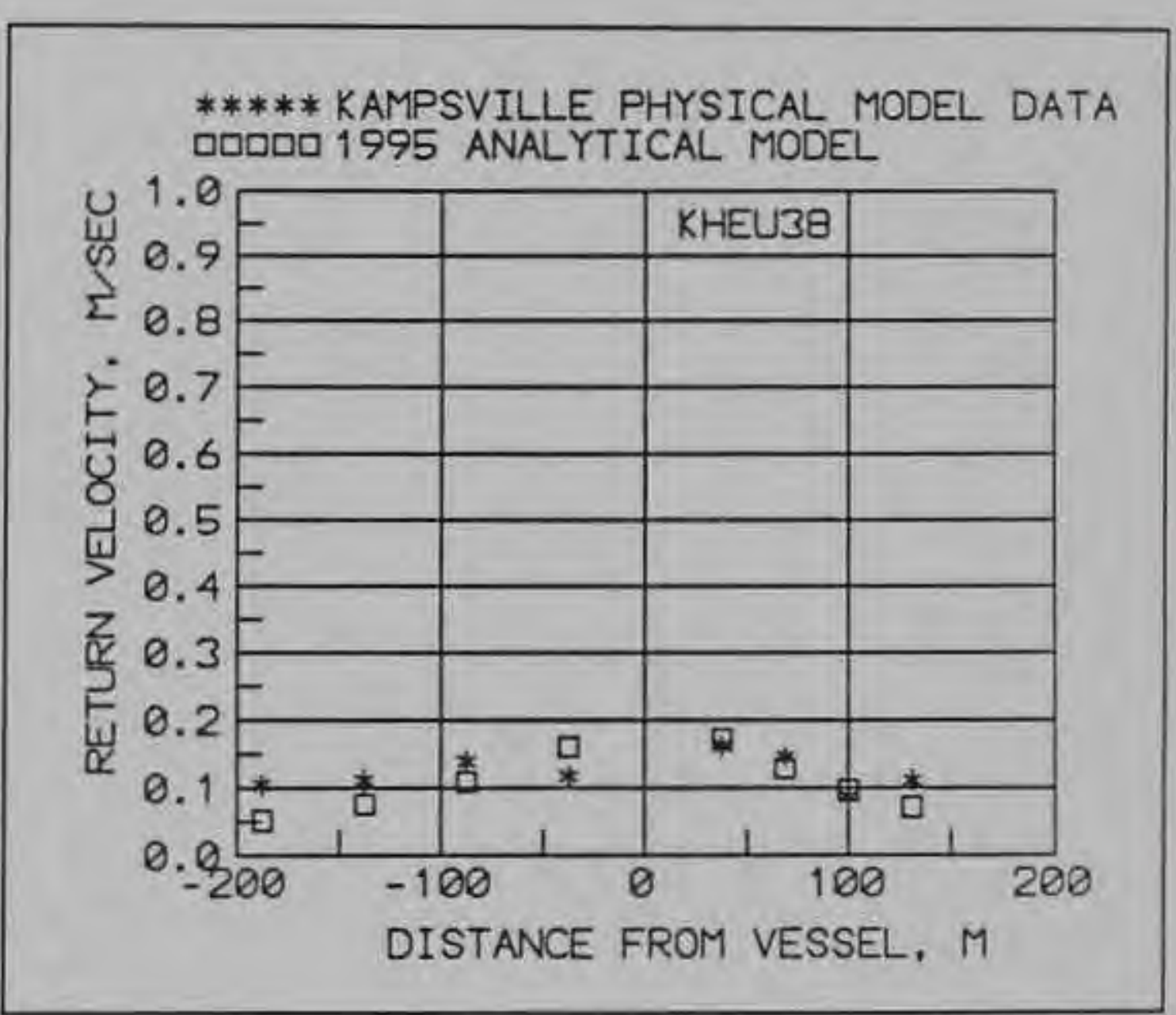

d. Test KHEU38

Figure 11. Observed Kampsville physical model return velocity versus computed return velocity using 1995 analytical method for individual tests: KL1U76, KLEU49, KLEU67, KHEU38, KHEU56, and KHOU38 (Continued) 


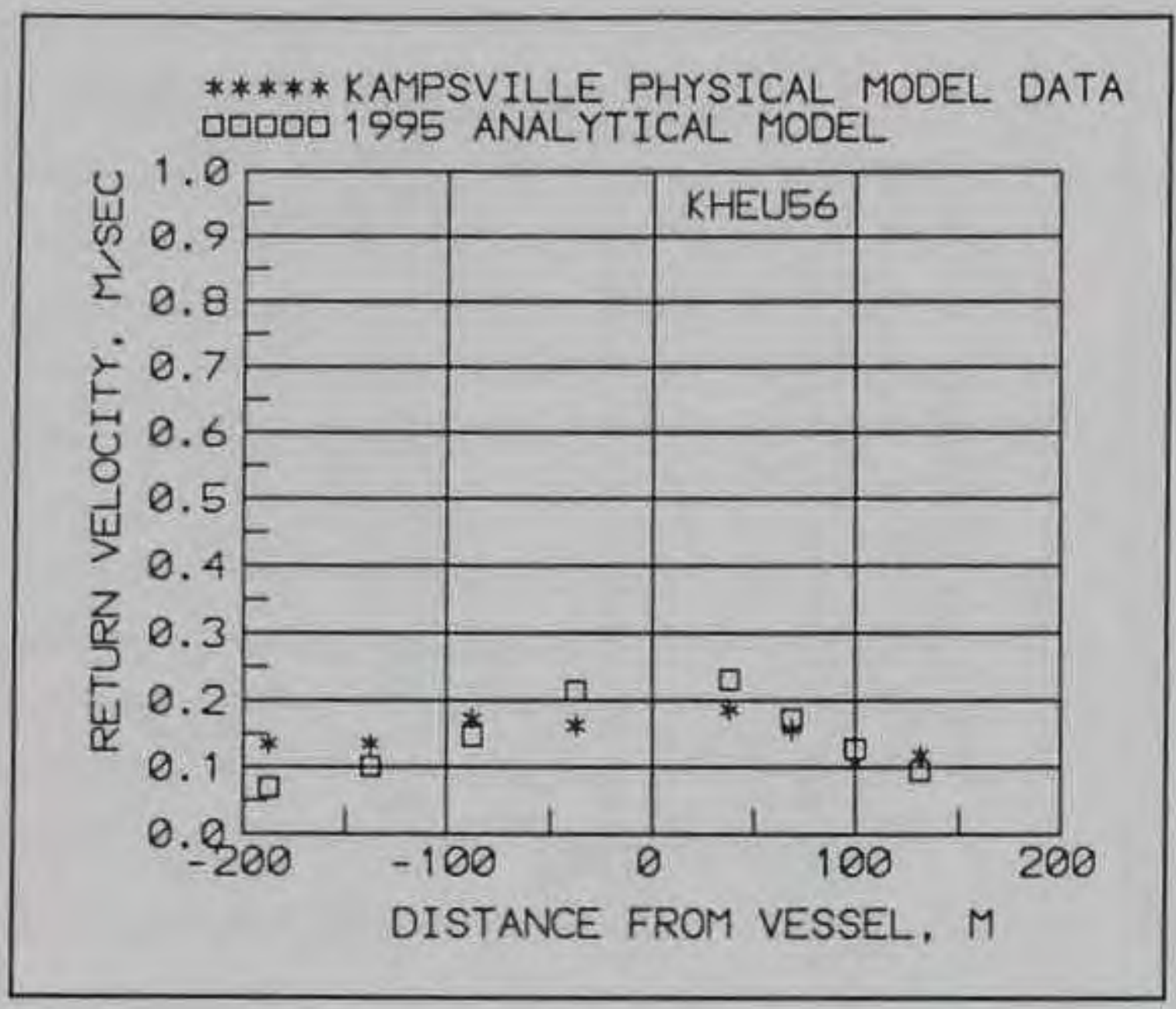

e. Test KHEU56

Figure 11. (Concluded)

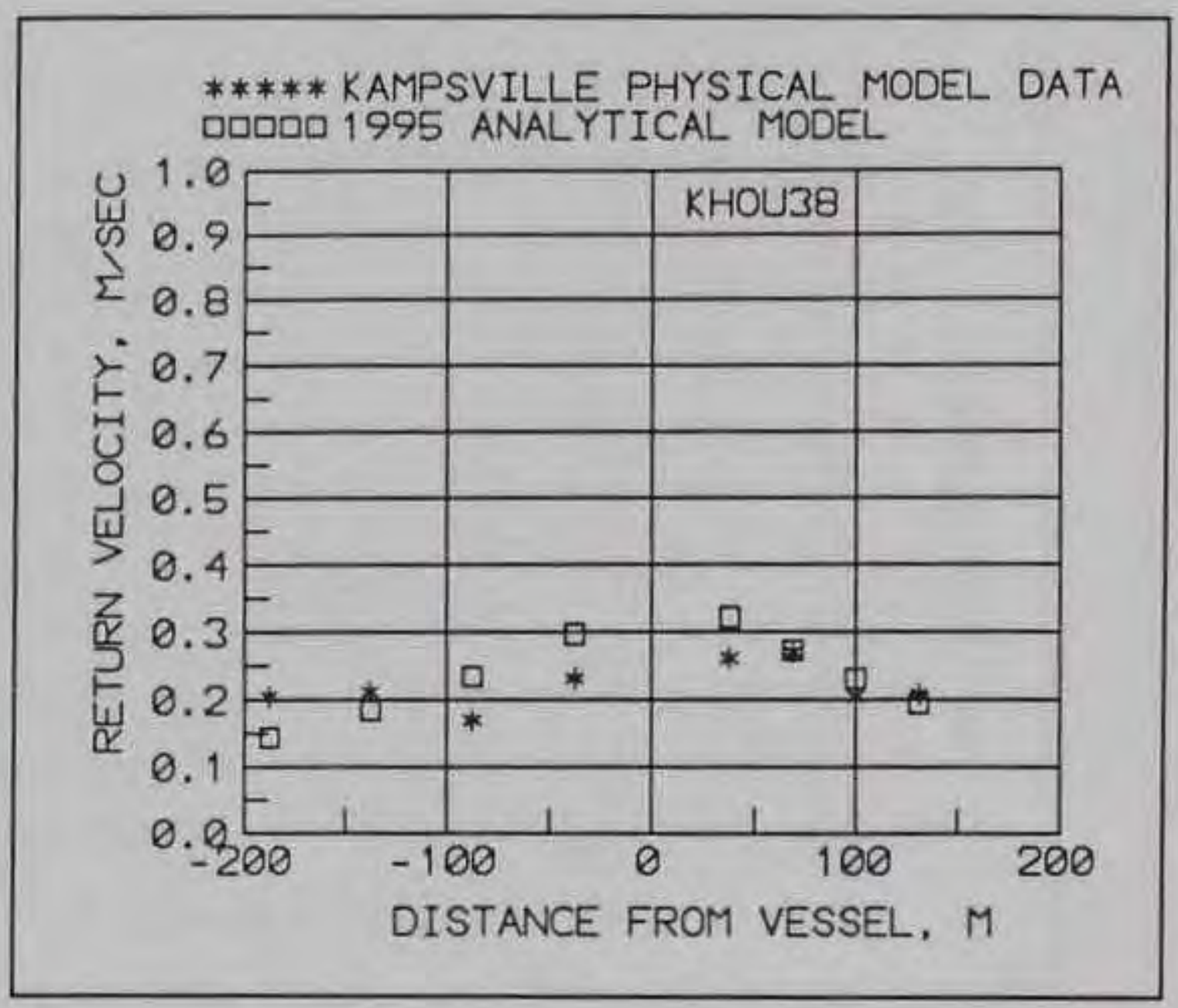

f. Test KHOU38 


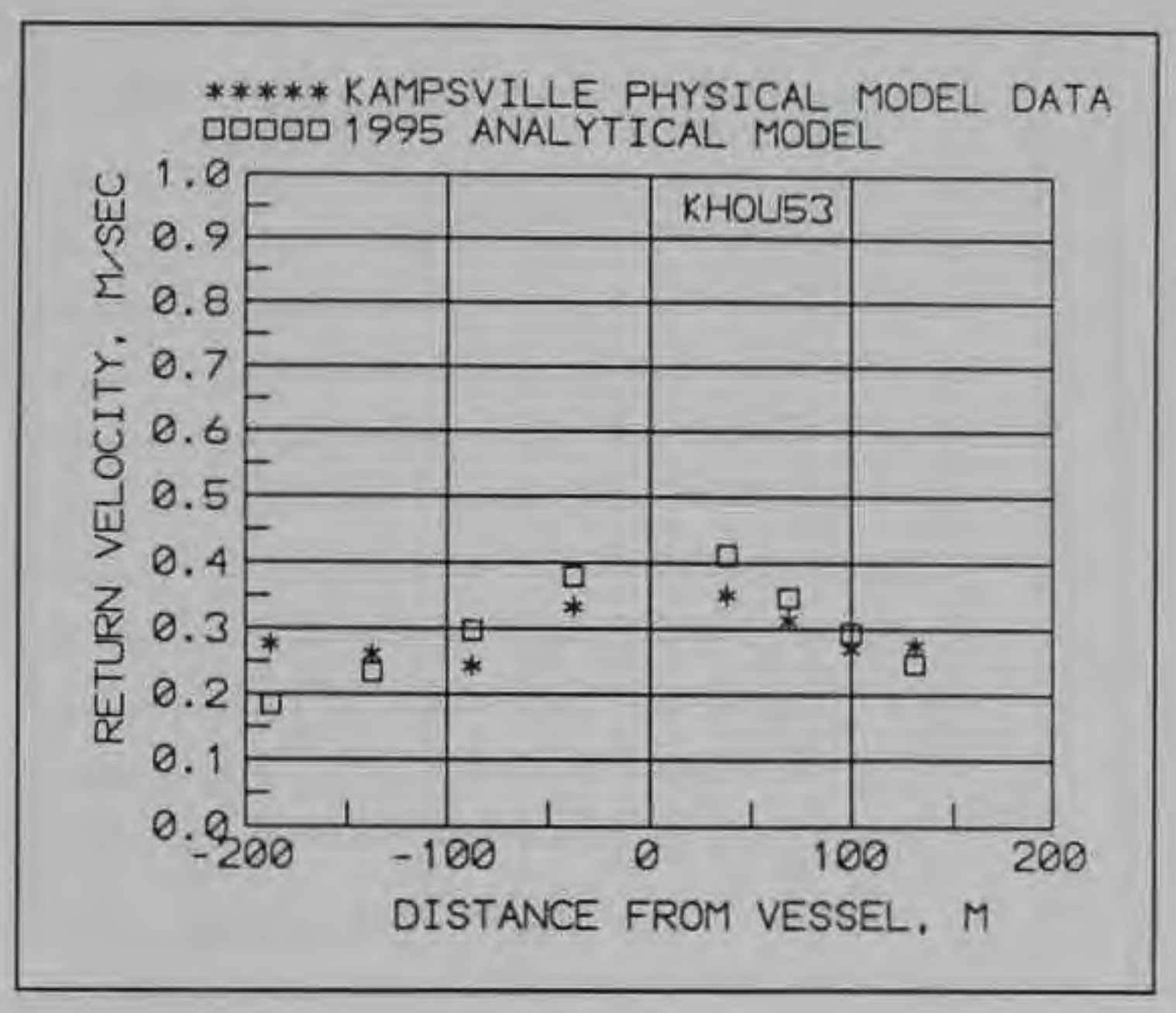

a. Test KHOU53

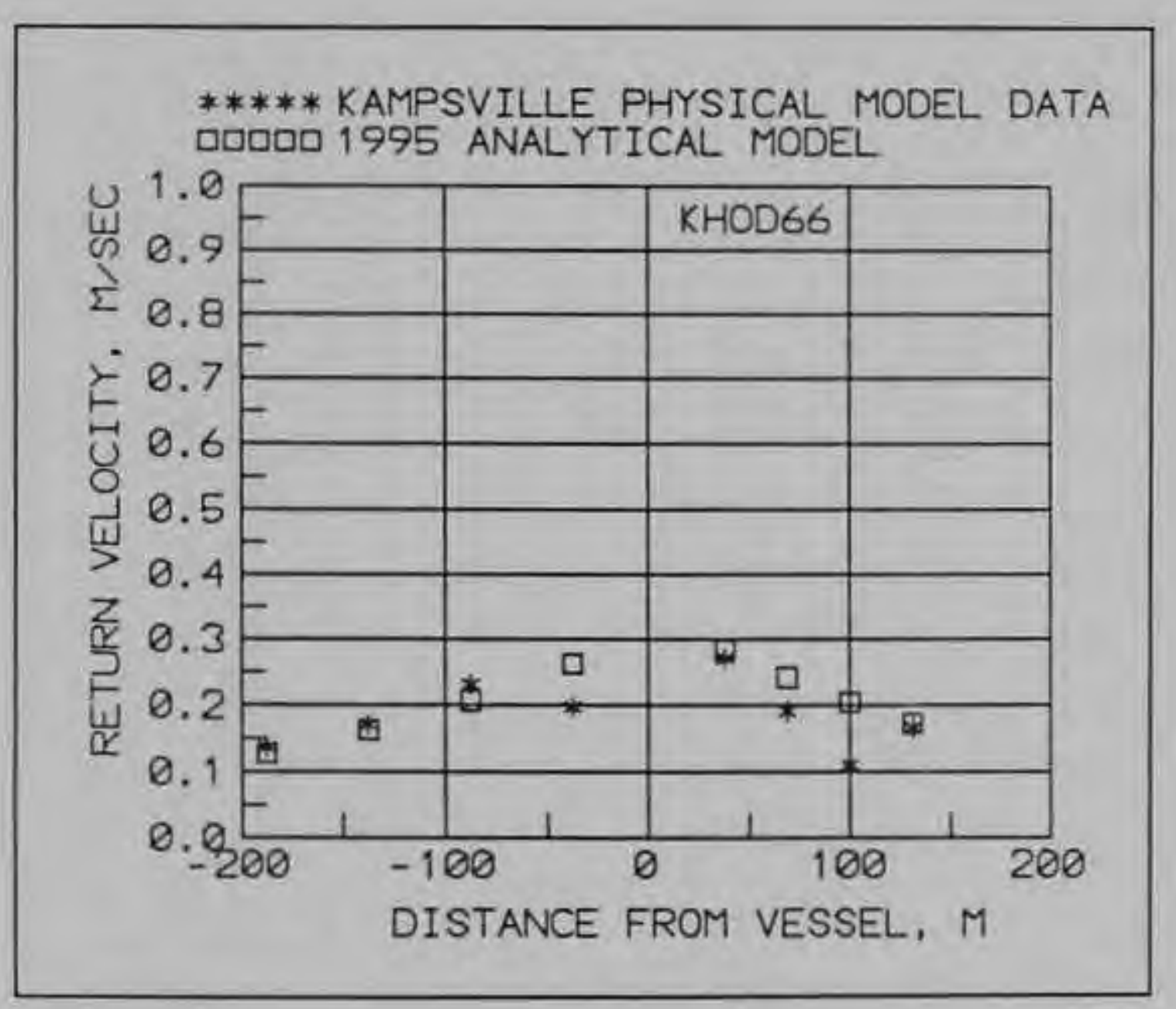

c. Test KHOD66

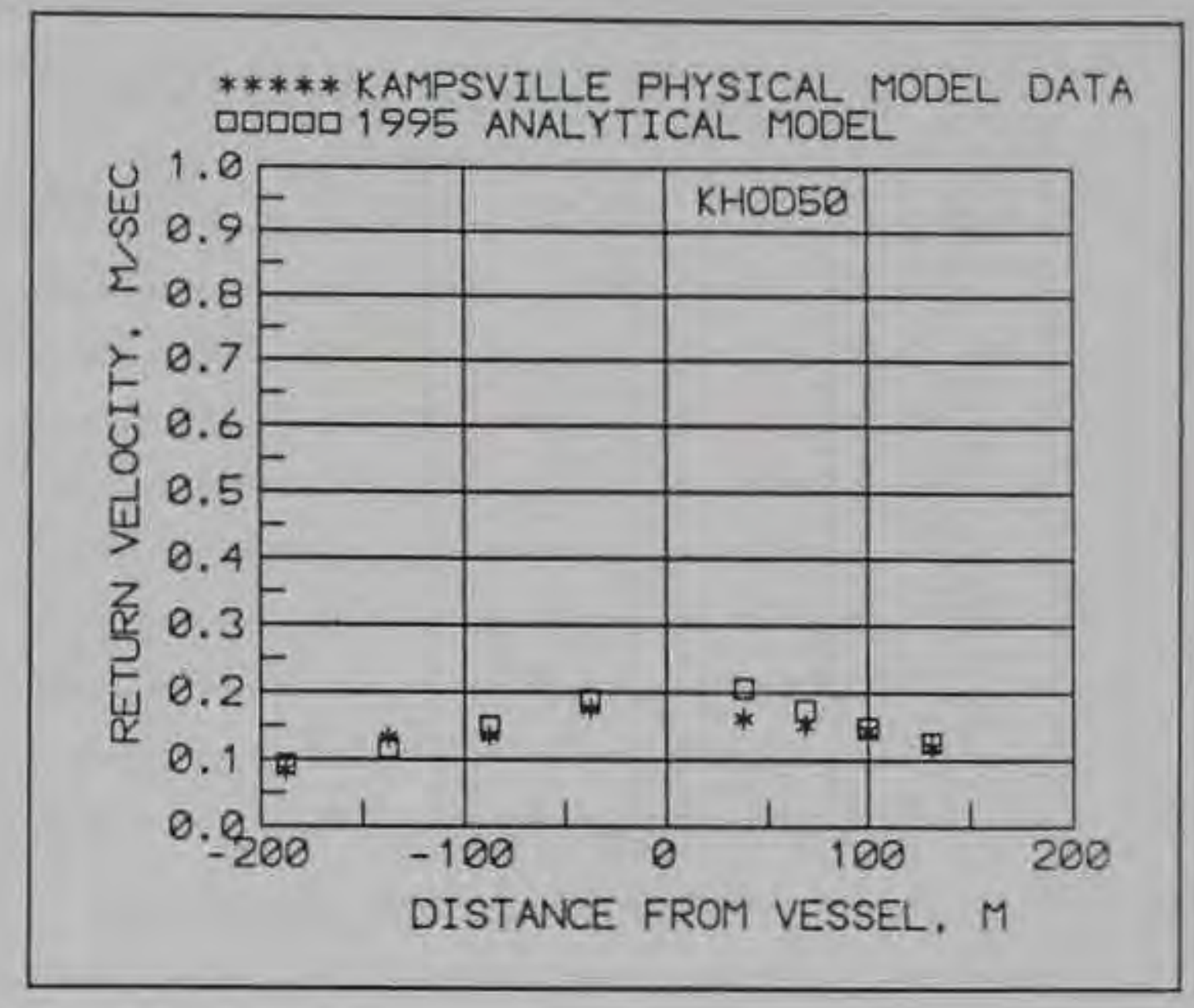

b. Test KHOD50

Figure 12. Observed Kampsville physical model return velocity versus computed return velocity using 1995 analytical method for individual tests: KHOU53, KHOD5O, KHOD66, KHRU38, KHRD66, and KHLU38 (Continued) 


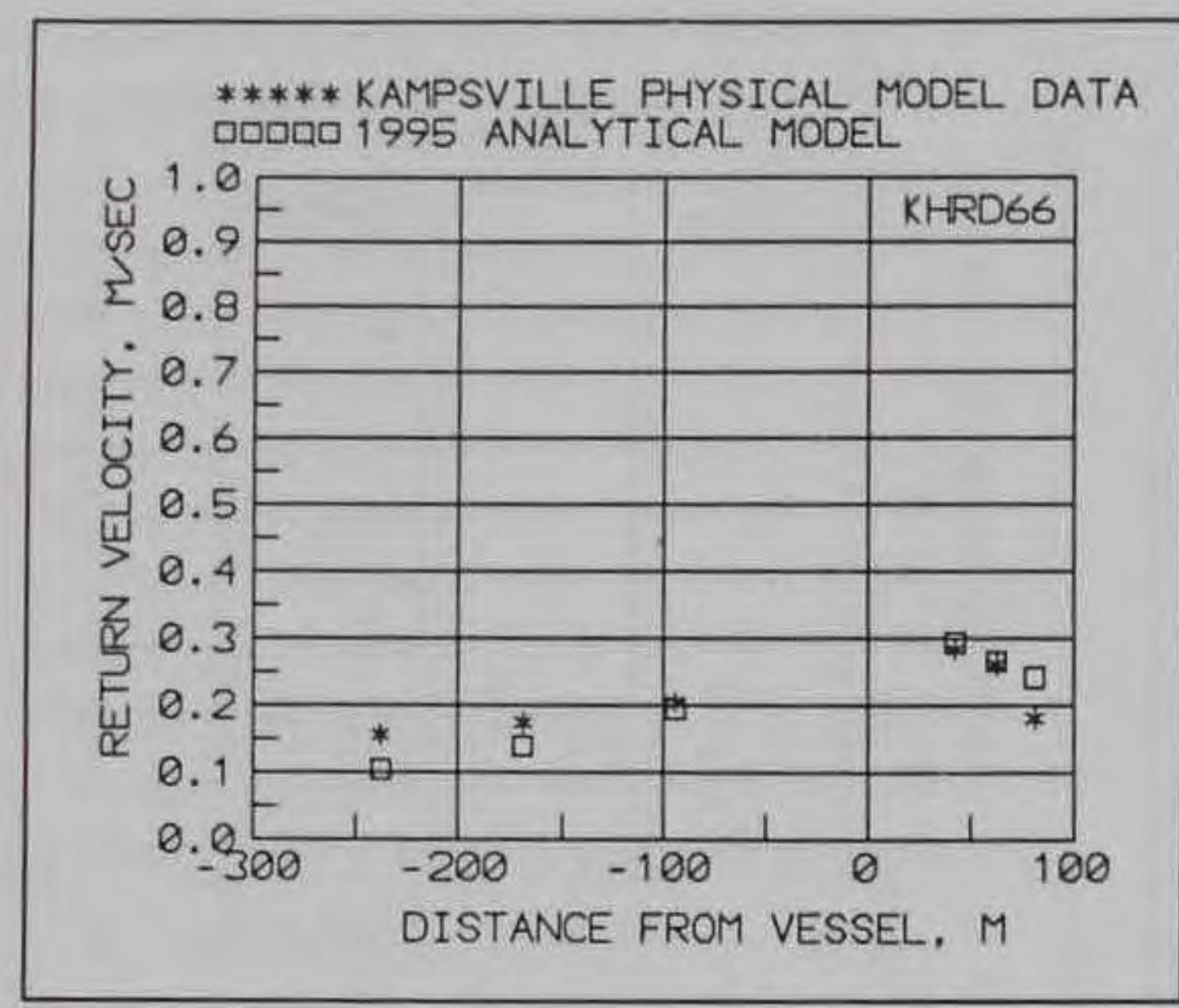

e. Test KHRD66

Figure 12. (Concluded)

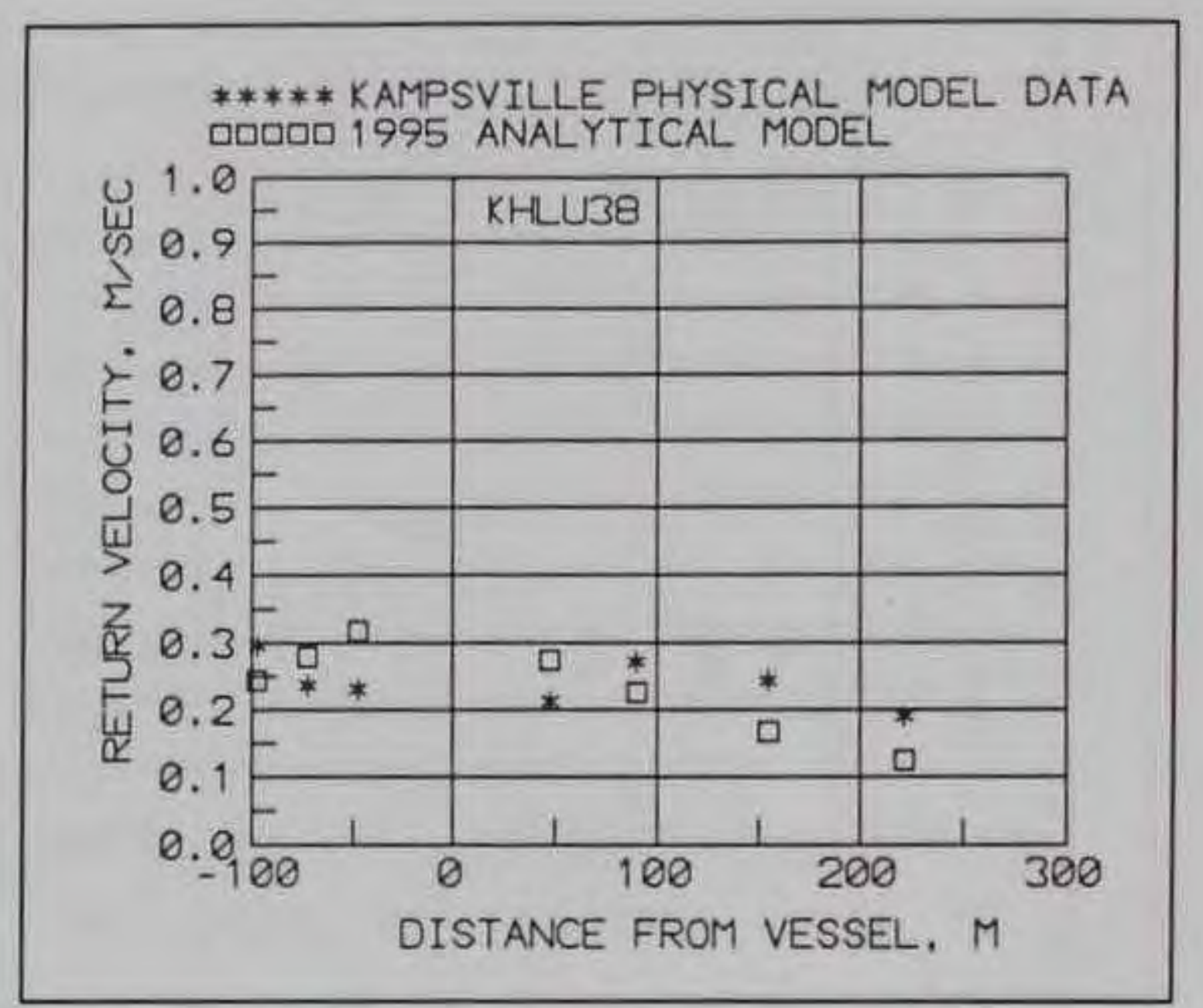

f. Test KHLU38 


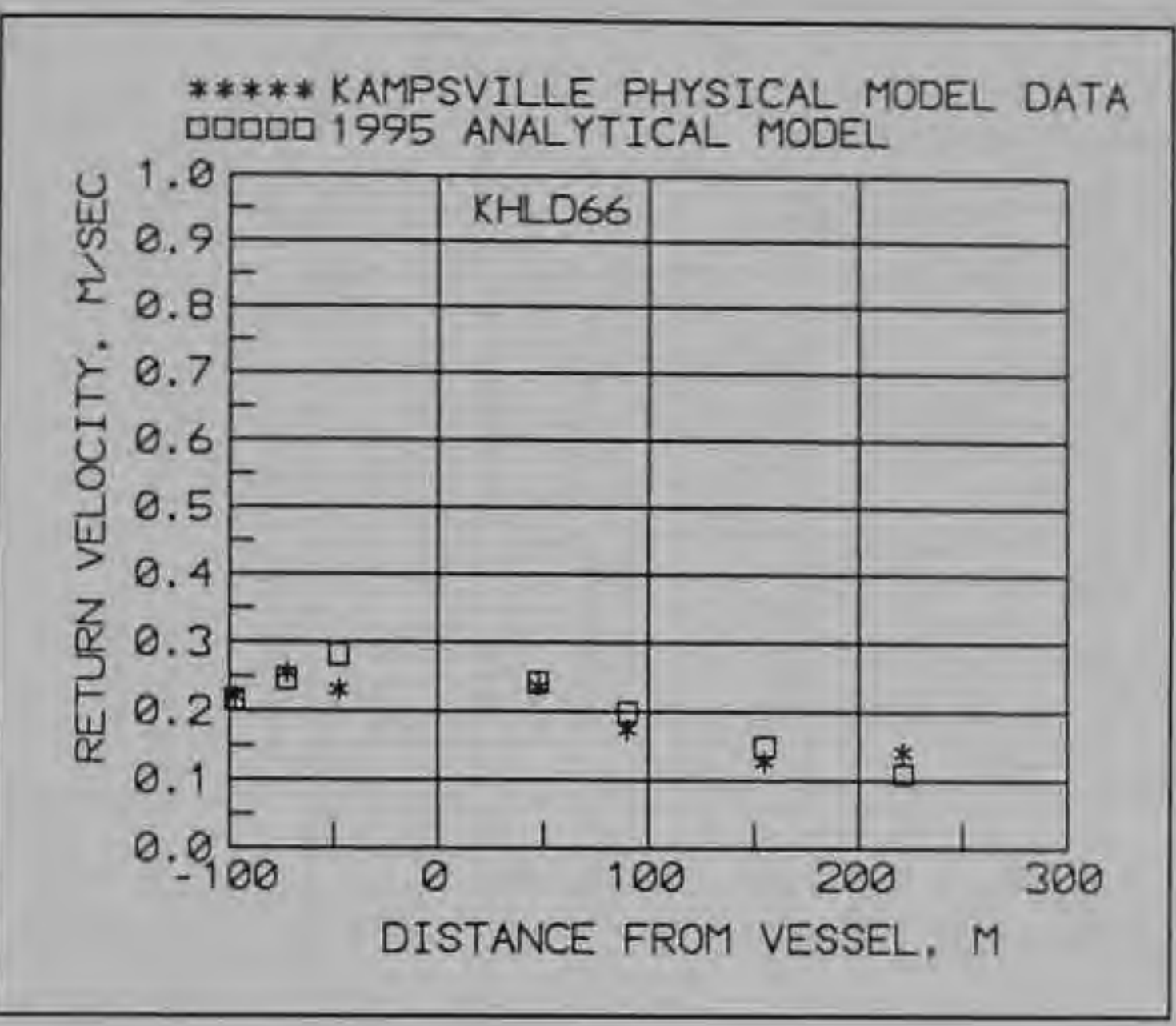

a. Test KHLD66

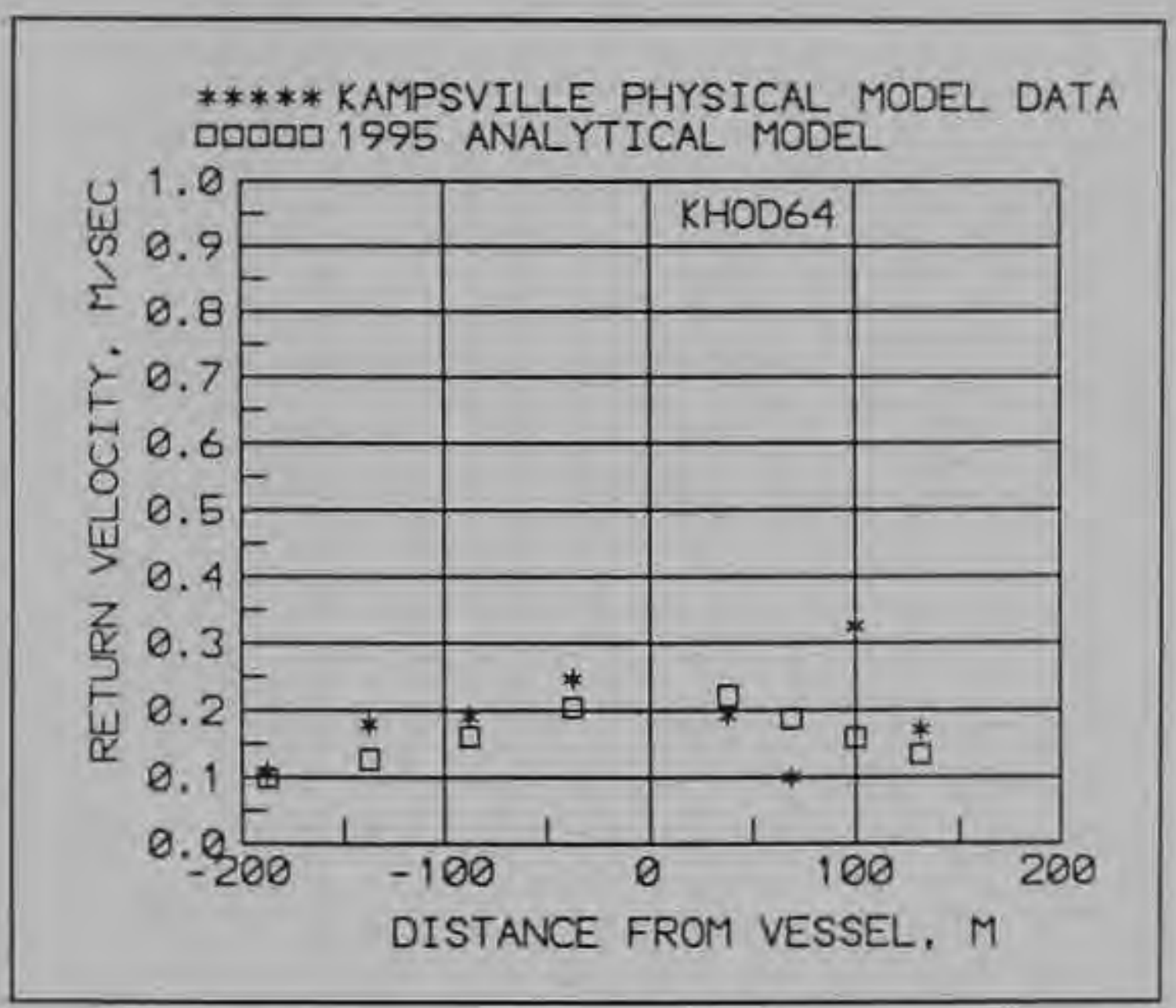

c. Test KHOD64

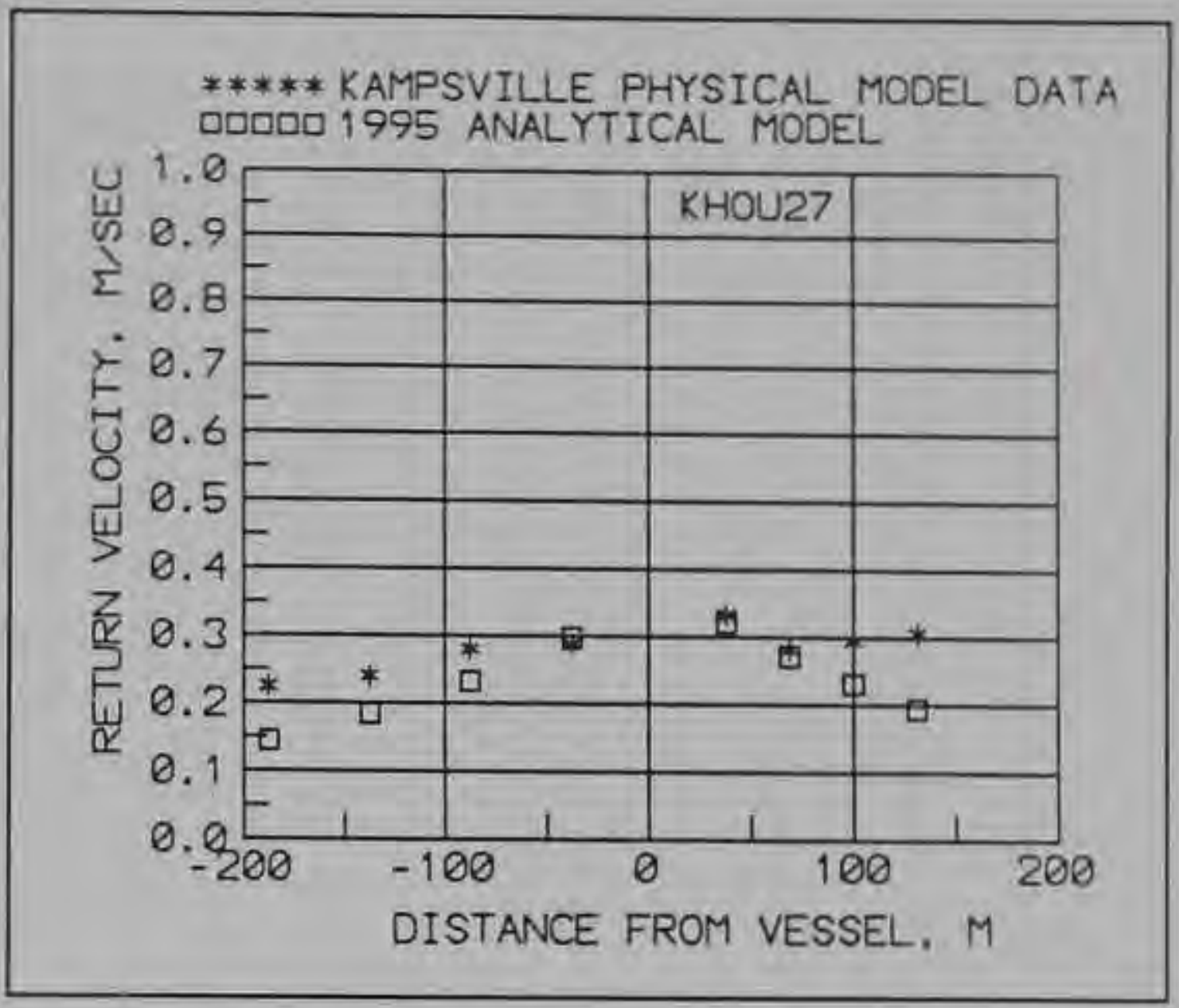

b. Test $\mathrm{KHOU} 27$

Figure 13. Observed Kampsville physical model return velocity versus computed return
velocity using 1995 analytical method for individual tests: KHLD66, KHOU27,

Figure 13. Observed Kampsville physical model return velocity versus computed return
velocity using 1995 analytical method for individual tests: KHLD66, KHOU27, KHOD64, LU38O2, and LD58Q2 (Continued)

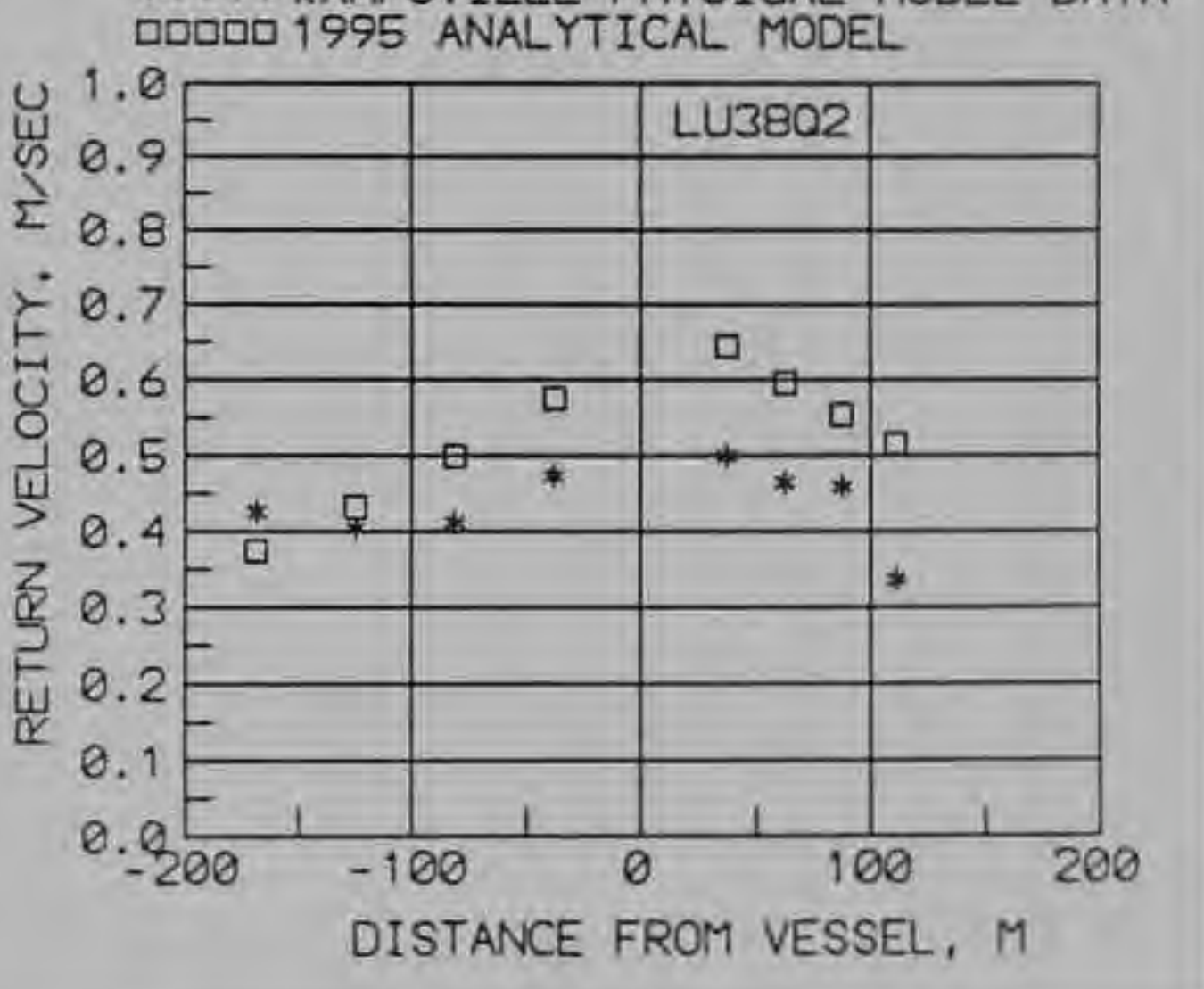

\section{d. Test LU38Q2}




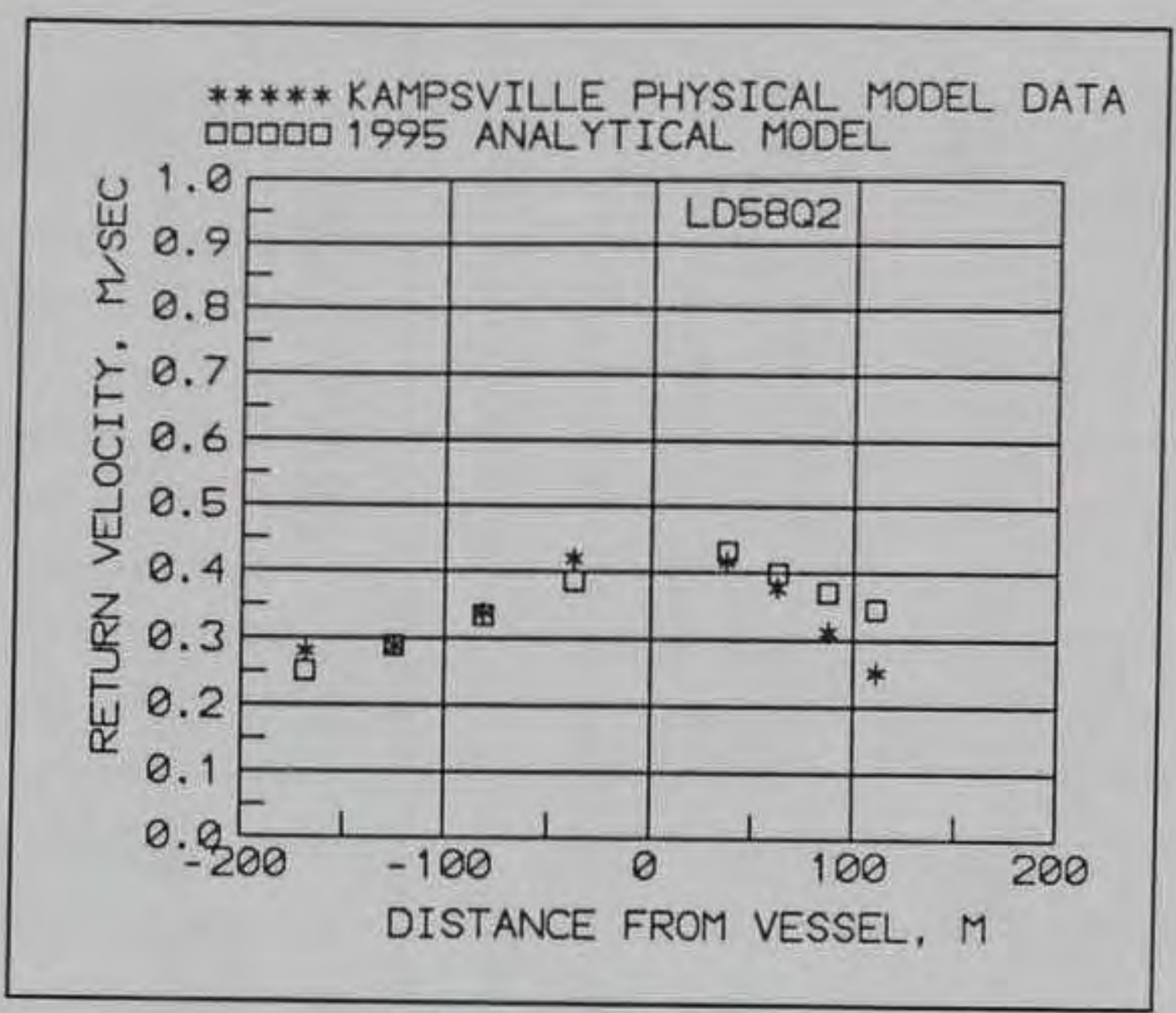

e. Test LD58Q2

Figure 13. (Concluded) 


\begin{tabular}{|c|c|c|c|c|c|c|c|c|c|c|c|}
\hline \multicolumn{12}{|c|}{$\begin{array}{l}\text { Table } 1 \\
\text { Physical Model Experimental Conditions }\end{array}$} \\
\hline $\begin{array}{l}\text { Test } \\
\text { Number } \\
\end{array}$ & $\begin{array}{l}\text { Vessel } \\
\text { Beam, m } \\
\end{array}$ & $\begin{array}{l}\text { Total } \\
\text { Length of } \\
\text { Barges, } m \\
\end{array}$ & $\begin{array}{l}\text { Effective } \\
\text { Draft, } m \\
\end{array}$ & $\begin{array}{l}\text { Vessel } \\
\text { Power, } \\
\text { Hp }\end{array}$ & $\begin{array}{l}\text { Vessel Speed } \\
\text { Relative to } \\
\text { Ground, } \\
\mathrm{m} / \mathrm{sec}\end{array}$ & $\begin{array}{l}\text { Ambient } \\
\text { Velocity, } \\
\mathrm{m} / \mathrm{sec}\end{array}$ & $\begin{array}{l}\text { Direction, } \\
1=\text { Upbound } \\
2=\text { Downbound }\end{array}$ & $\begin{array}{l}\text { Channel } \\
\text { Area } \\
\text { Left of } \\
\text { Vessel, } \\
\mathrm{m}^{2} \\
\end{array}$ & $\begin{array}{l}\text { Distance } \\
\text { from Left } \\
\text { Bank to } \\
\text { Vessel m } \\
\end{array}$ & $\begin{array}{l}\text { Total } \\
\text { Channel } \\
\text { Area, } \mathrm{m}^{2} \\
\end{array}$ & $\begin{array}{l}\text { Total } \\
\text { Channel } \\
\text { Width, } m\end{array}$ \\
\hline KLU335 & 32.00 & 297.3 & 2.85 & 5600. & 1.67 & 0.175 & 1. & 617.3 & 186.0 & 1032.5 & 315.0 \\
\hline KLU488 & 32.00 & 297.3 & 2.81 & 5600. & 2.43 & 0.175 & 1. & 617.3 & 186.0 & 1032.5 & 315.0 \\
\hline KLU640 & 32.00 & 297.3 & 2.78 & 5600. & 3.18 & 0.175 & 1. & 617.3 & 186.0 & 1032.5 & 315.0 \\
\hline KLD354 & 32.00 & 297.3 & 2.86 & 5600. & 1.79 & 0.175 & -1. & 617.3 & 186.0 & 1032.5 & 315.0 \\
\hline KLD506 & 32.00 & 297.3 & 2.82 & 5600. & 2.50 & 0.175 & -1. & 617.3 & 186.0 & 1032.5 & 315.0 \\
\hline KLD659 & 32.00 & 297.3 & 2.79 & 5600. & 3.32 & 0.175 & -1. & 617.3 & 186.0 & 1032.5 & 315.0 \\
\hline KLRU49 & 32.00 & 297.3 & 2.81 & 5600. & 2.43 & 0.175 & 1. & 775.4 & 226.0 & 1032.5 & 315.0 \\
\hline KLRD 49 & 32.00 & 297.3 & 2.83 & 5600. & 2.43 & 0.175 & -1. & 775.4 & 226.0 & 1032.5 & 315.0 \\
\hline KLLU49 & 32.00 & 297.3 & 2.82 & 5600. & 2.45 & 0.175 & 1. & 324.2 & 111.0 & 1032.5 & 315.0 \\
\hline KLLD51 & 32.00 & 297.3 & 2.83 & 5600. & 2.52 & 0.175 & -1. & 324.2 & 111.0 & 1032.5 & 315.0 \\
\hline KL1U46 & 10.67 & 178.4 & 2.65 & 5600. & 2.28 & 0.175 & 1. & 617.3 & 186.0 & 1032.5 & 315.0 \\
\hline KL1U61 & 10.67 & 178.4 & 2.63 & 5600. & 3.03 & 0.175 & 1. & 617.3 & 186.0 & 1032.5 & 315.0 \\
\hline KL1U76 & 10.67 & 178.4 & 2.61 & 5600. & 3.81 & 0.175 & 1. & 617.3 & 186.0 & 1032.5 & 315.0 \\
\hline KLEU49 & 32.00 & 297.3 & 1.14 & 5600. & 2.43 & 0.175 & 1. & 617.3 & 186.0 & 1032.5 & 315.0 \\
\hline KLEU67 & 32.00 & 297.3 & 1.14 & 5600. & 3.34 & 0.175 & 1. & 617.3 & 186.0 & 1032.5 & 315.0 \\
\hline KHEU38 & 32.00 & 297.3 & 1.15 & 5600. & 1.91 & 0.71 & 1. & 1075.6 & 209.9 & 1817.0 & 362.4 \\
\hline KHEU56 & 32.00 & 297.3 & 1.12 & 5600. & 2.82 & 0.71 & 1. & 1075.6 & 209.9 & 1817.0 & 362.4 \\
\hline KHOU38 & 32.00 & 297.3 & 2.83 & 5600. & 1.91 & 0.71 & 1. & 1075.6 & 209.9 & 1817.0 & 362.4 \\
\hline KHOU53 & 32.00 & 297.3 & 2.79 & 5600. & 2.67 & 0.71 & 1. & 1075.6 & 209.9 & 1817.0 & 362.4 \\
\hline
\end{tabular}




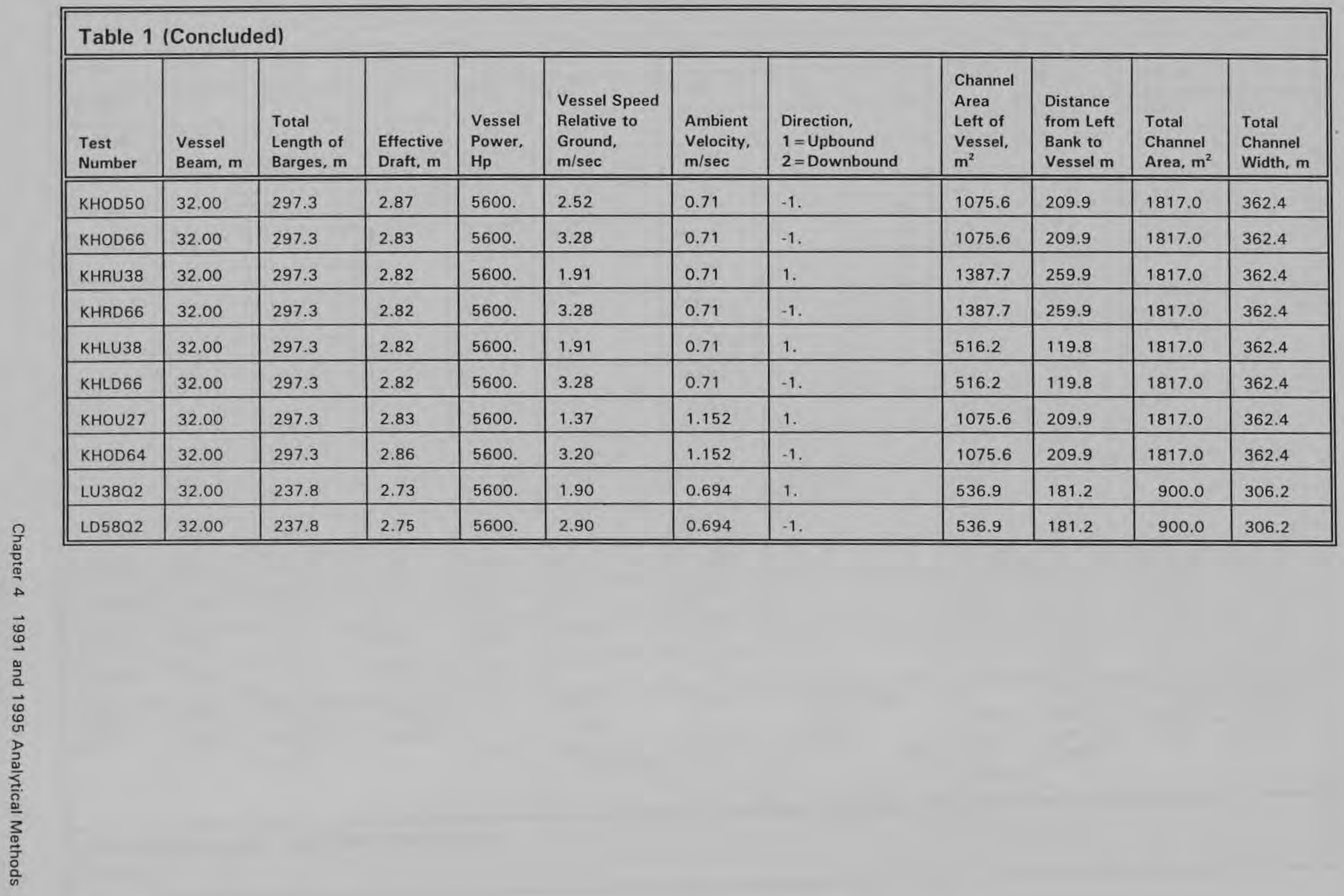




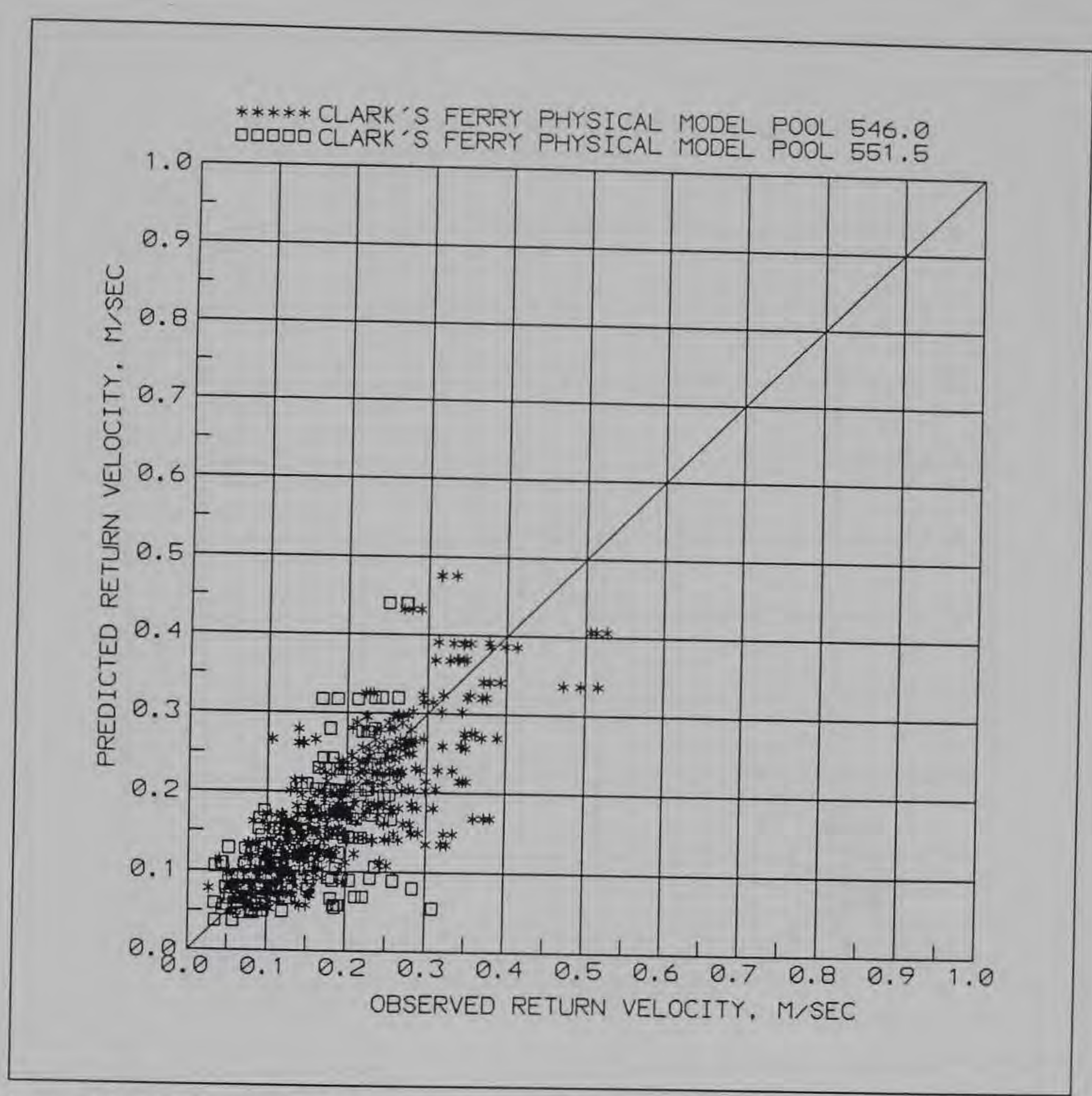

Figure 14. Observed Clark's Ferry physical model return velocity versus computed return velocity using 1995 analytical method for $N<52$ 


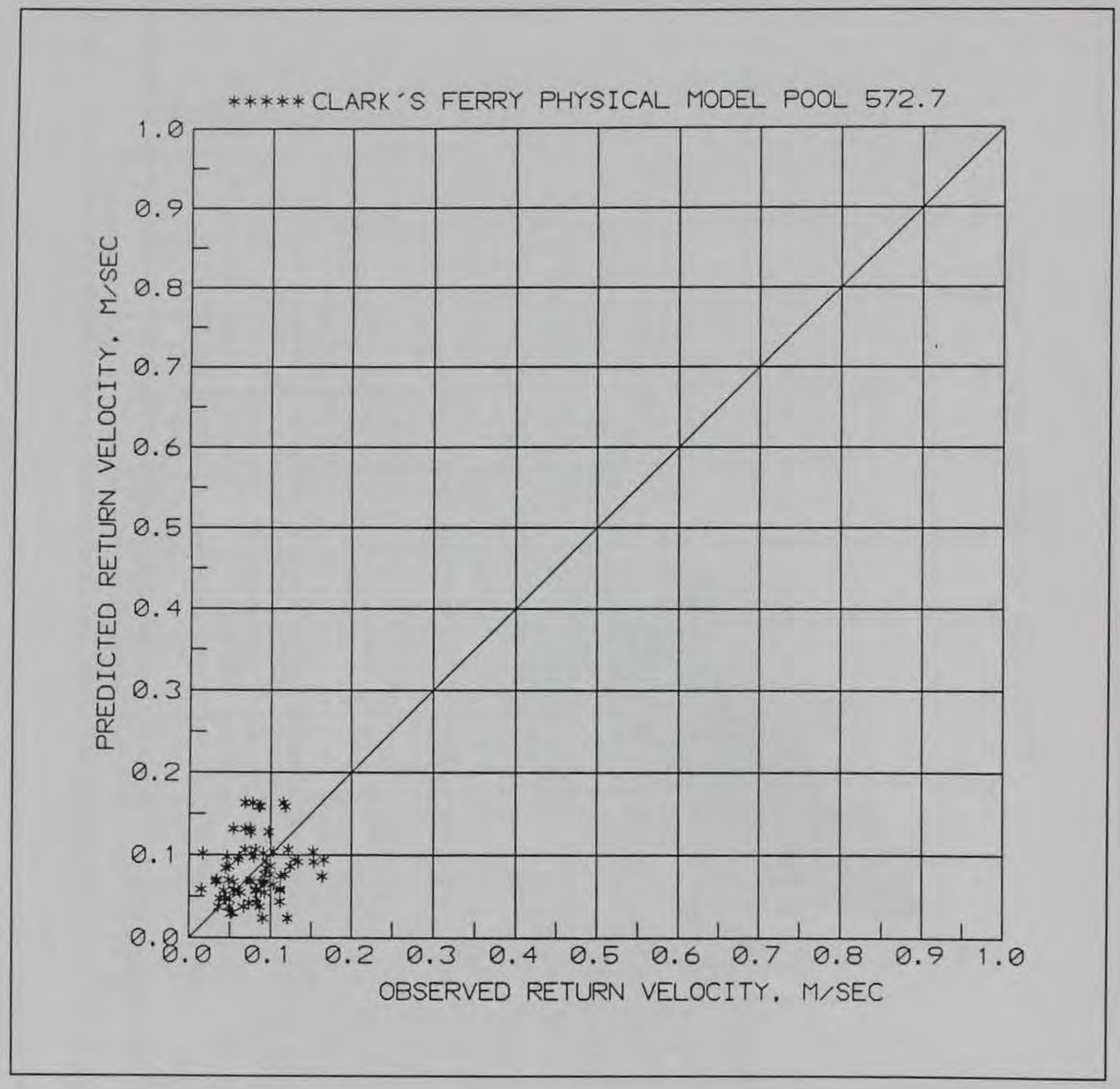

Figure 15. Observed Clark's Ferry physical model return velocity versus computed return velocity using 1995 analytical method for $N=85$ 


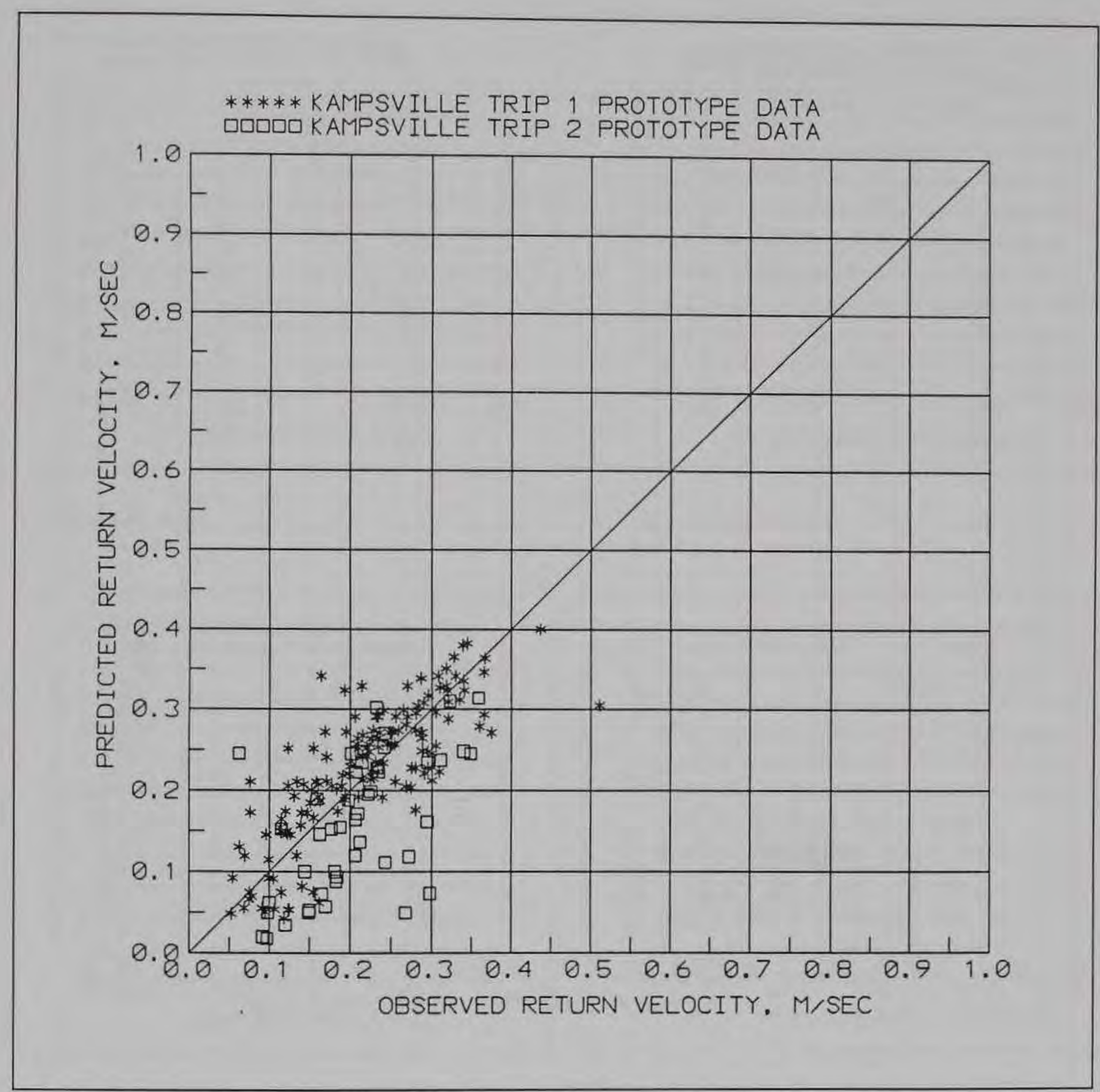

Figure 16. Observed Kampsville prototype return velocity versus computed return velocity using 1995 analytical method 


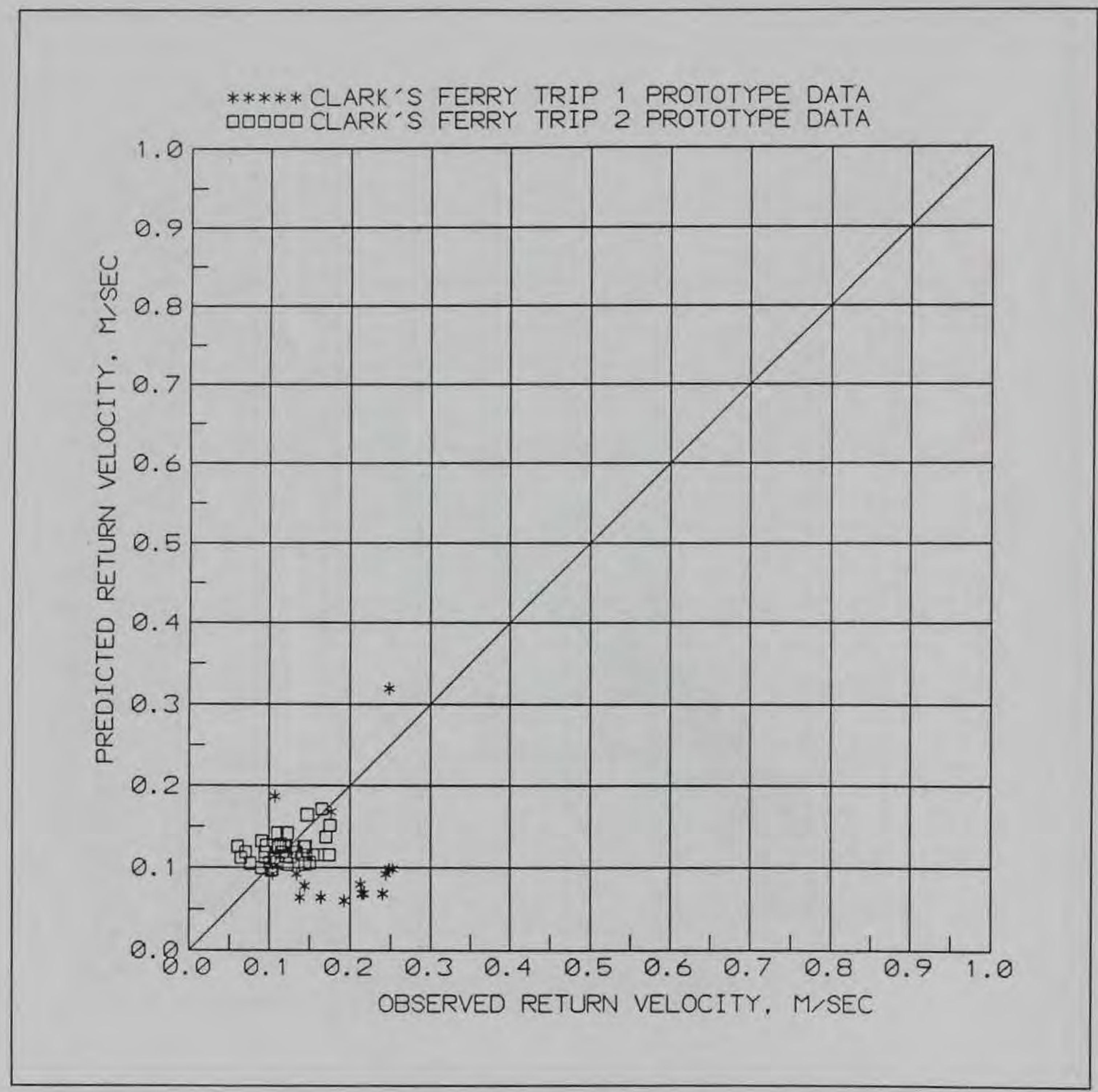

Figure 17. Observed Clark's Ferry prototype return velocity versus computed return velocity using 1995 analytical method 


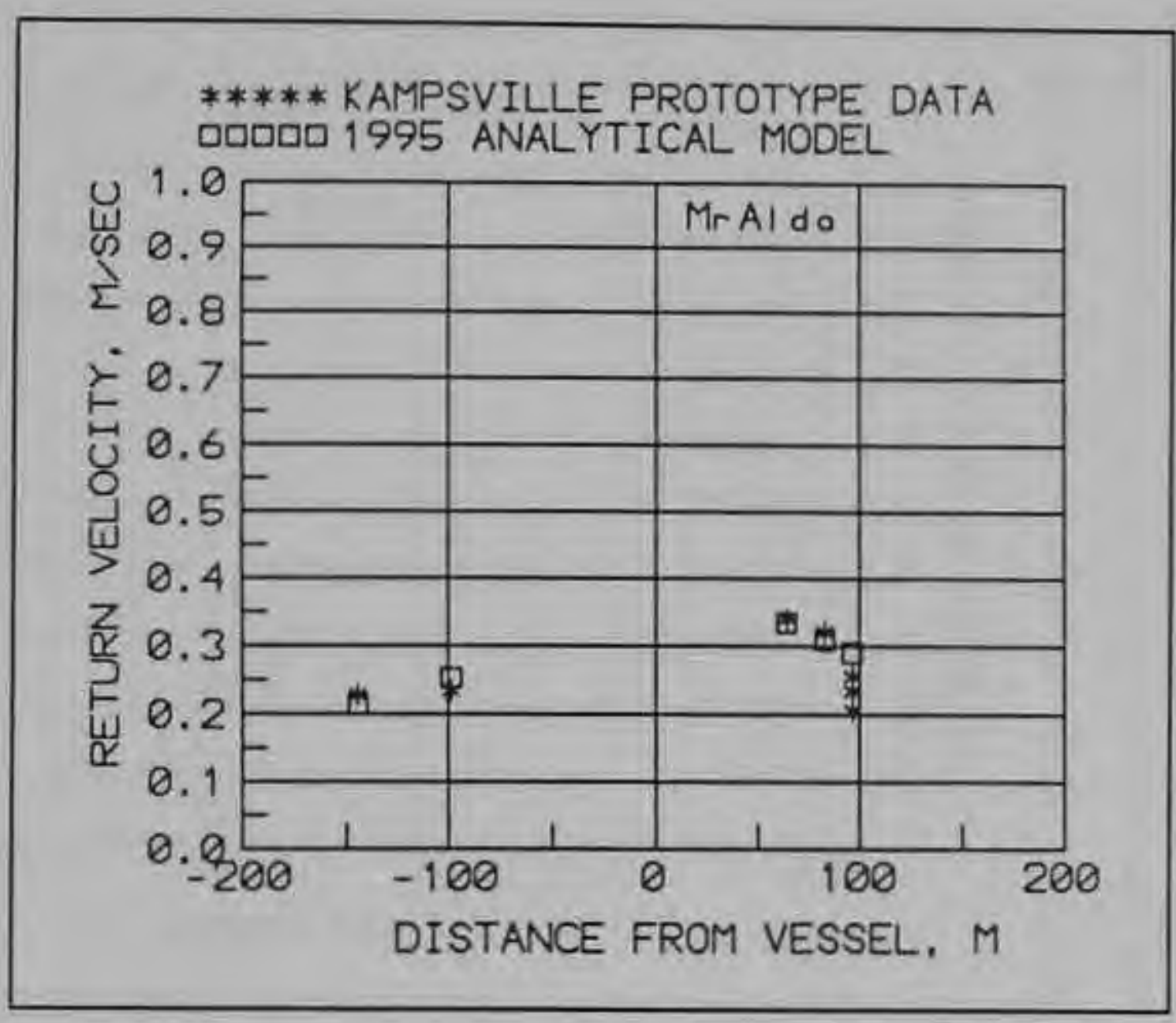

a. M/V Mr. Aldo

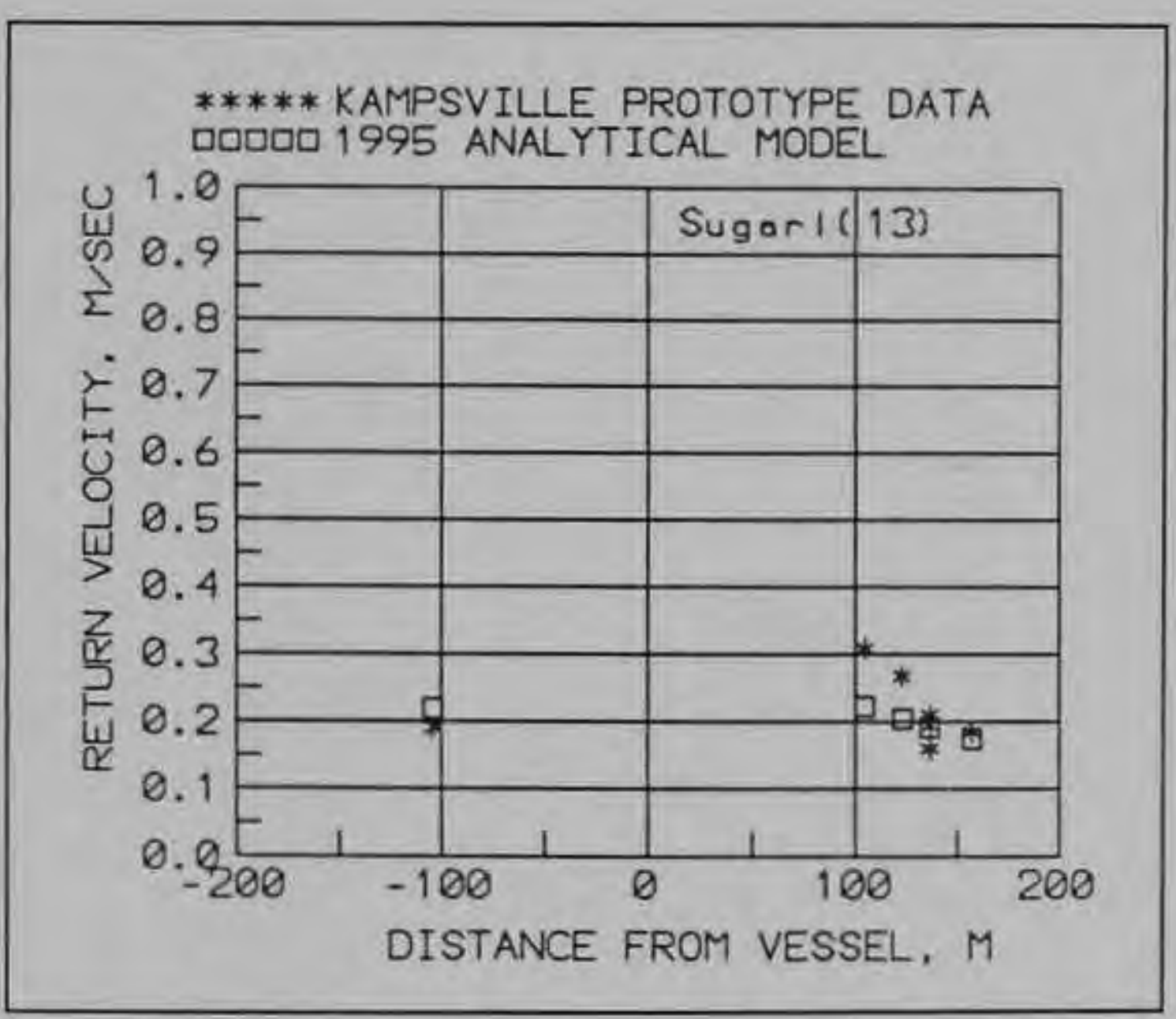

c. $M / V$ Sugarl (13)

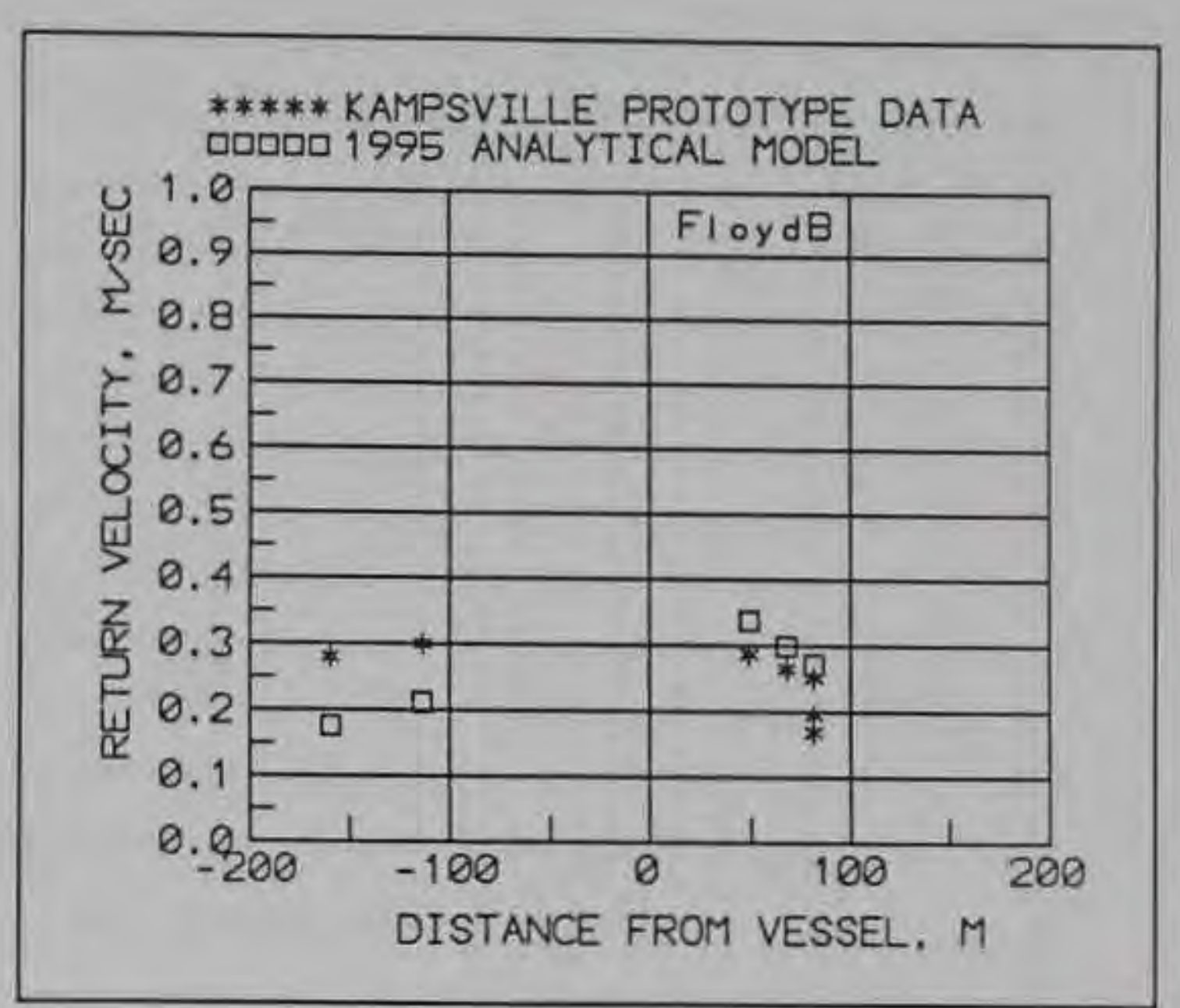

b. M/V Floyd Blaske

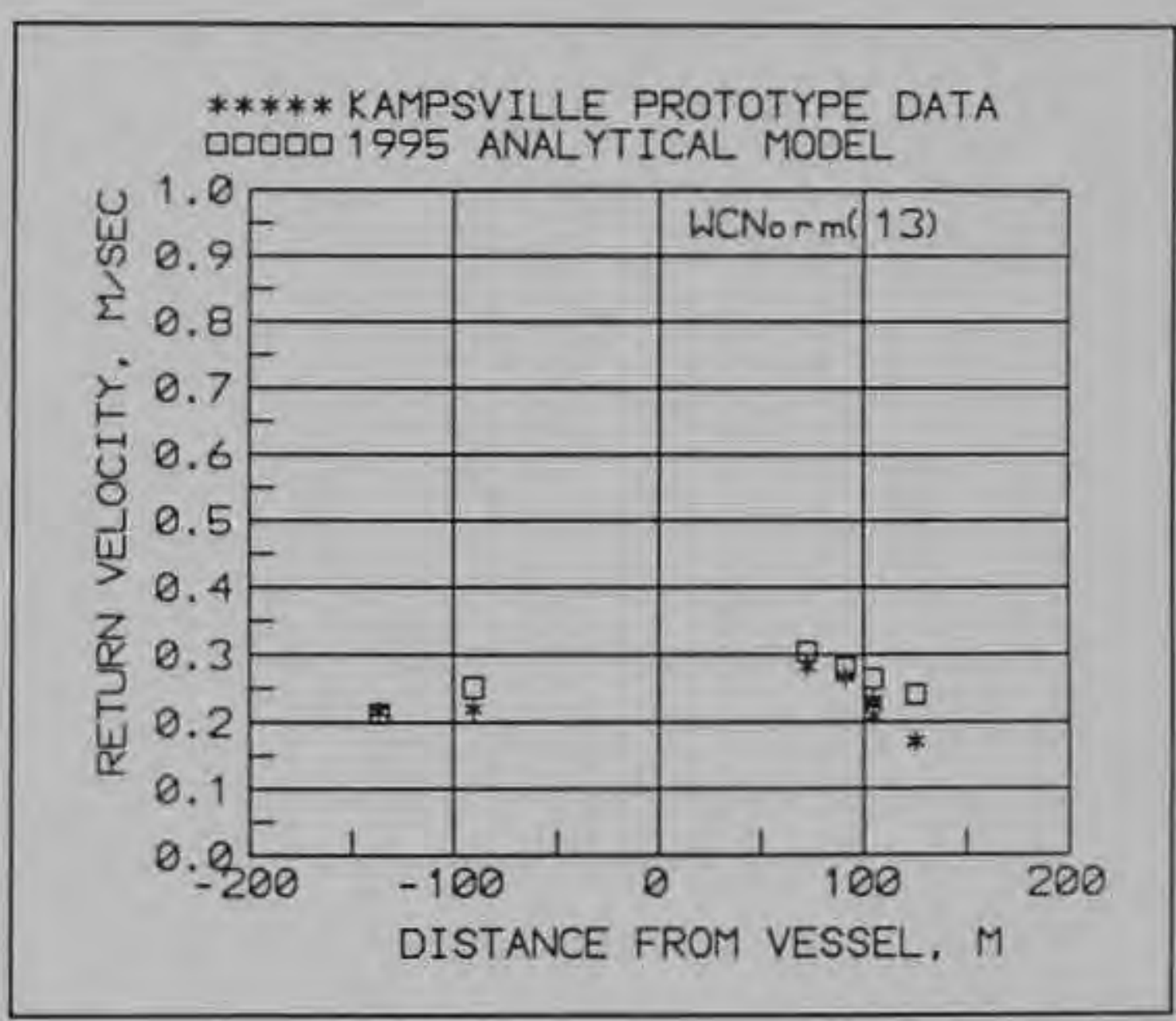

d. M/V W. C. Norman (13)

Figure 18. Observed Kampsville prototype return velocity versus computed return velocity using 1995 analytical method for individual tests: M/V Mr. Abdo, Floyd Blaske, Sugar (13), W. C. Norman (13), ContiKarla, and Rambler (Continued) 


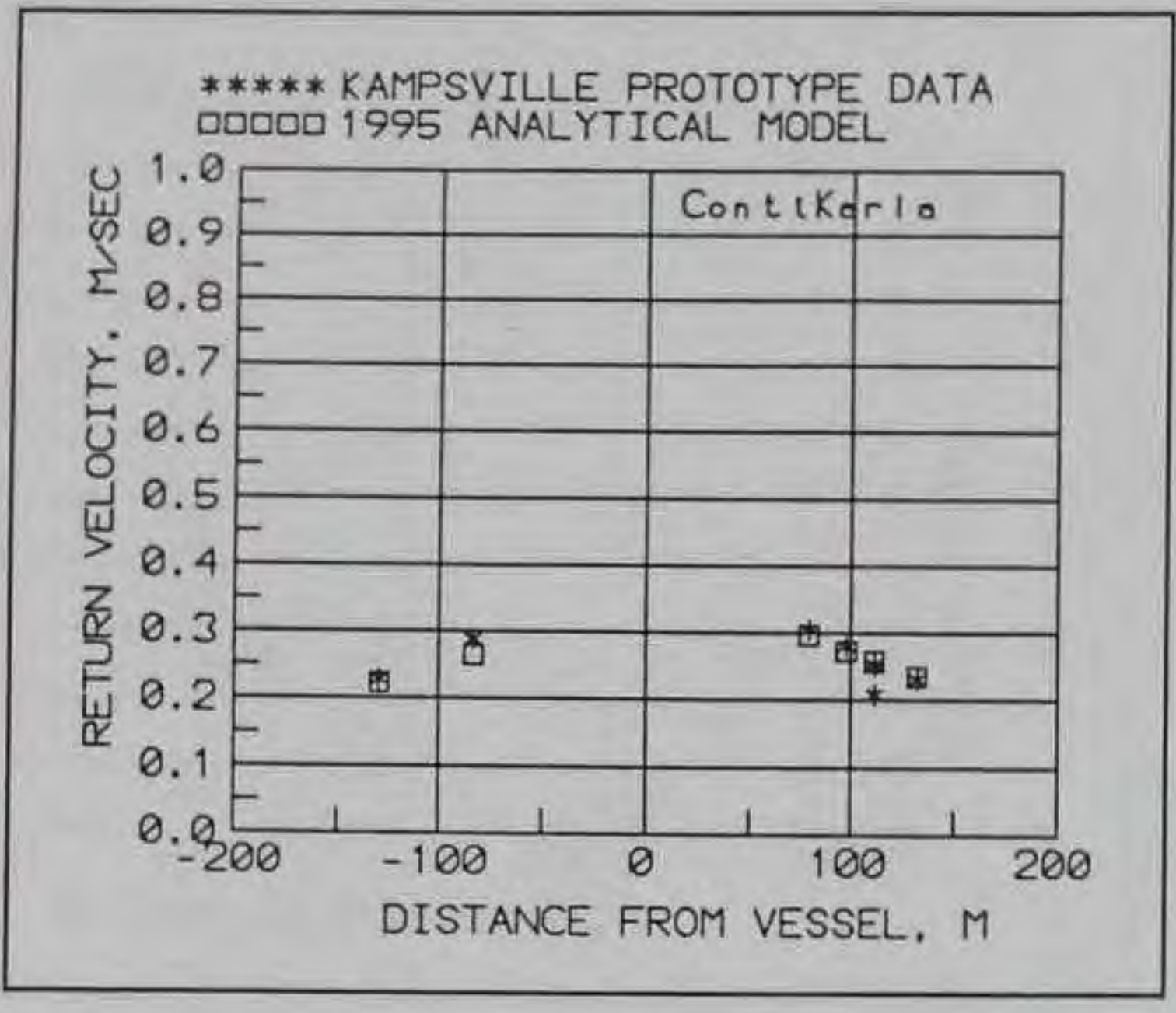

e. M/V Conti Karla

Figure 18. (Concluded)

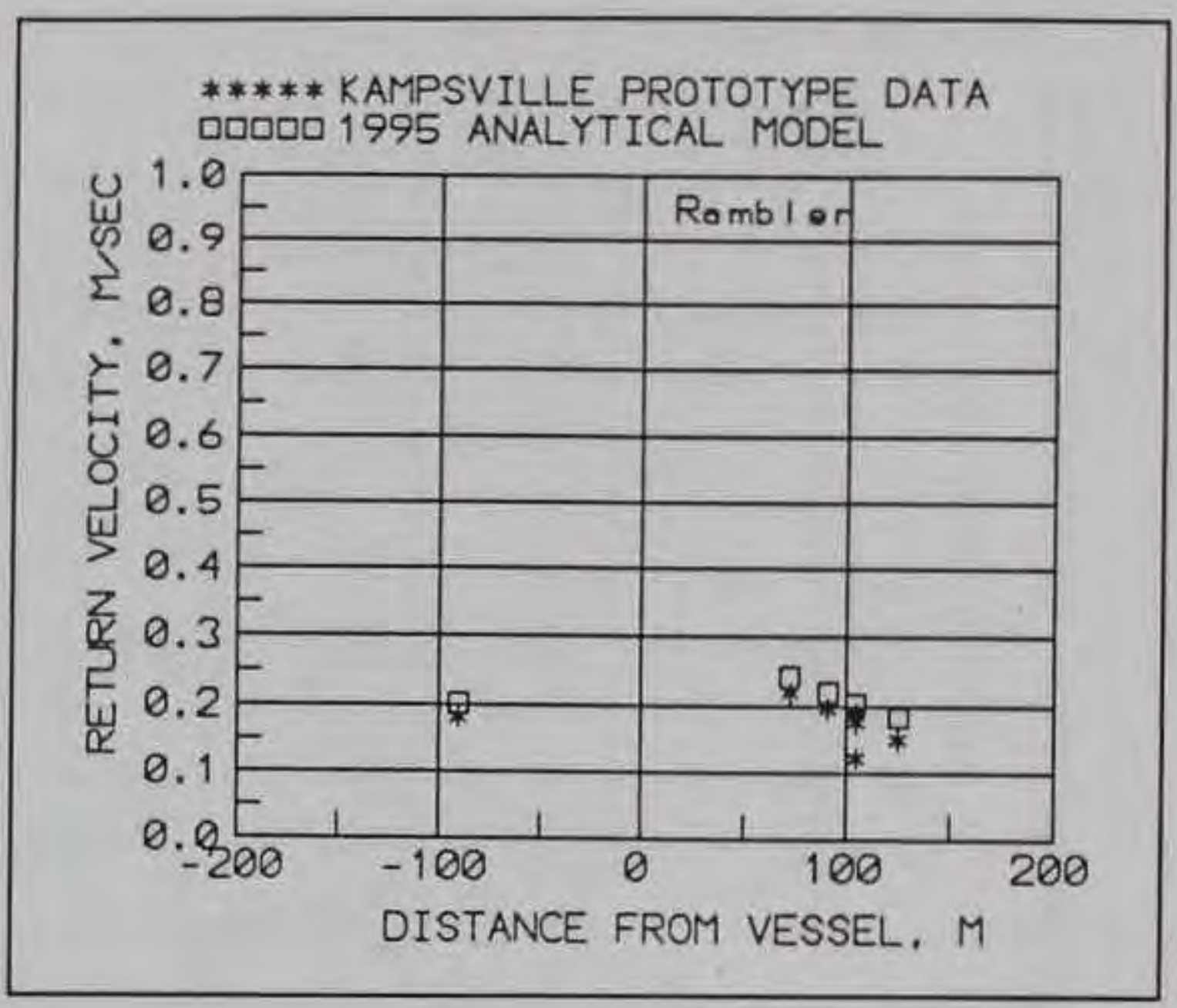

f. M/V Rambler 


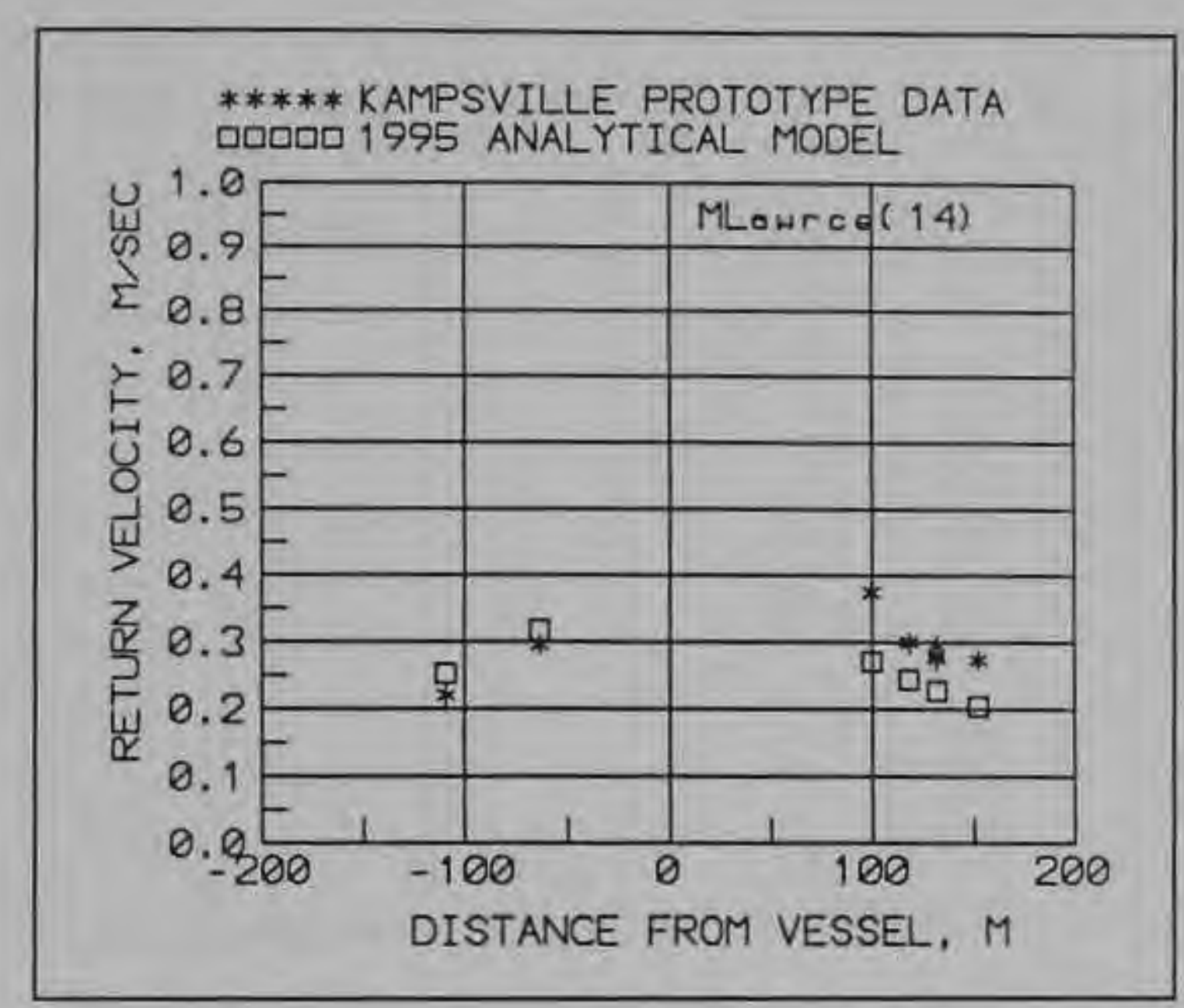

a. M/V Mlawrce (14)

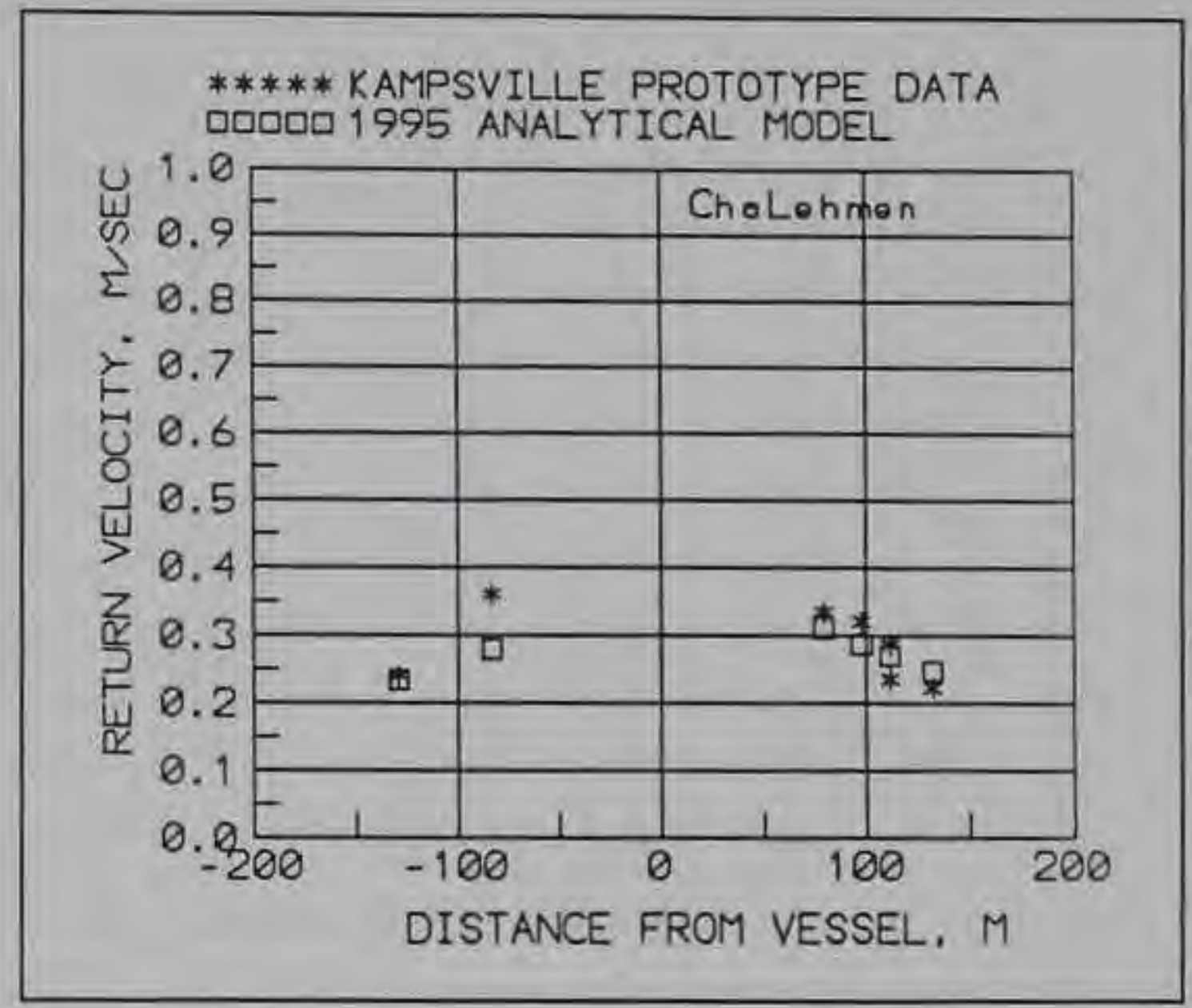

b. M/V ChaLehman

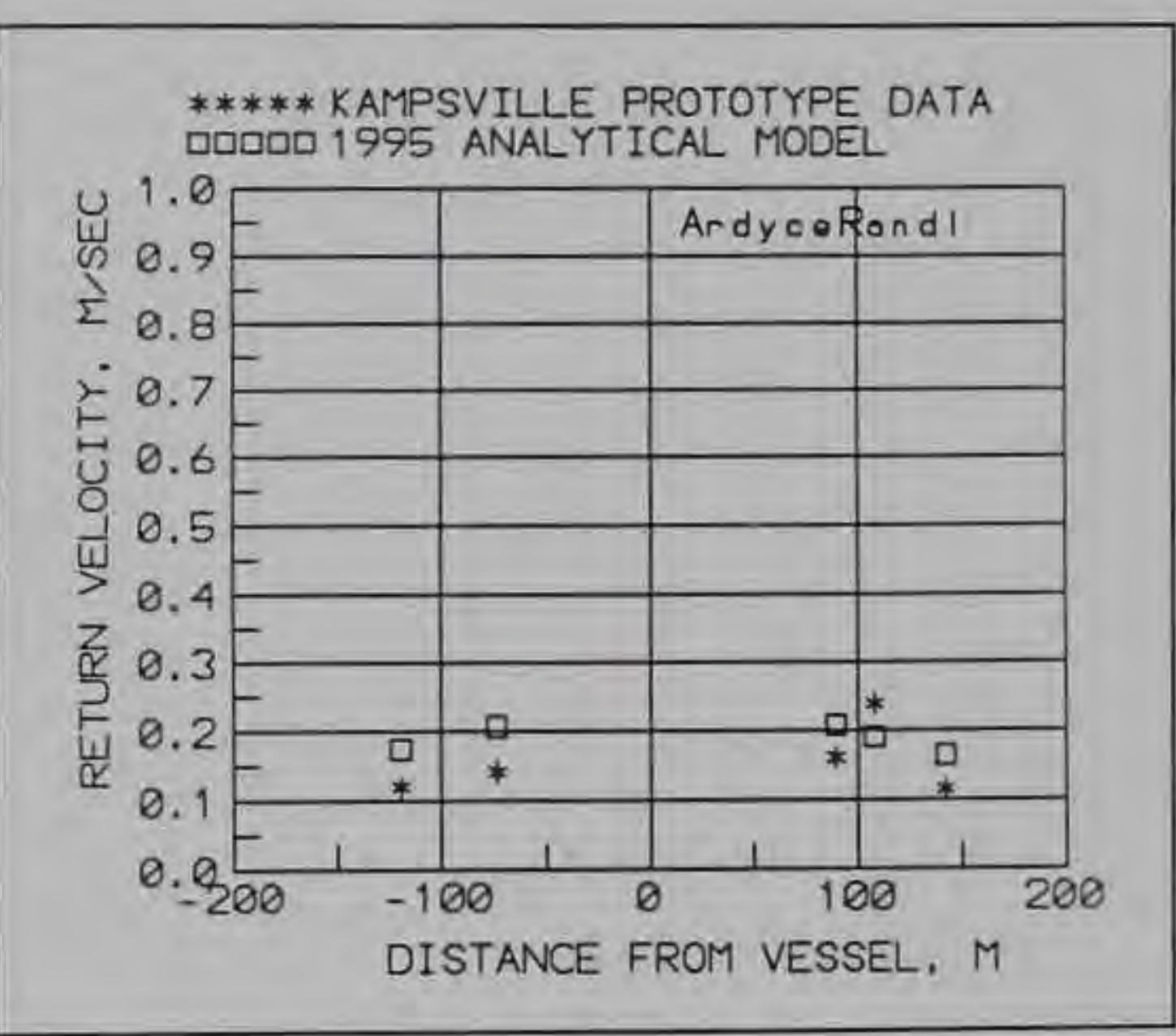

d. M/V Ardyce Randl

c. Jeffboat

Figure 19. Observed Kampsville prototype return velocity versus computed return velocity using 1995 analytical method for individual tests: M/V Mlawrce, ChaLehman, Jeffboat, Ardyce Randl, Mr. Paul (15), and Marget O (15) (Continued) 


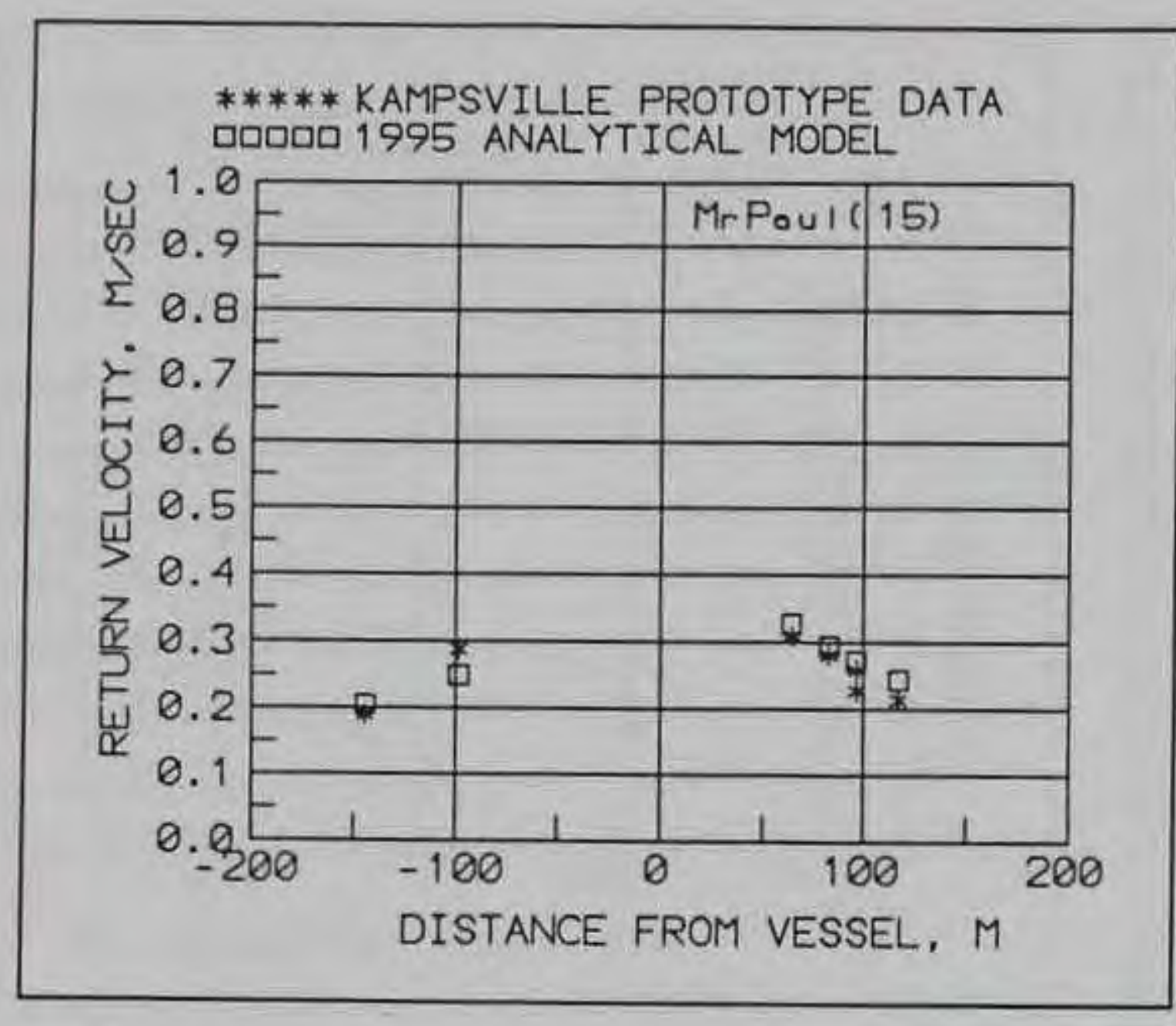

e. M/V Mr. Paul (15)

Figure 19. (Concluded)

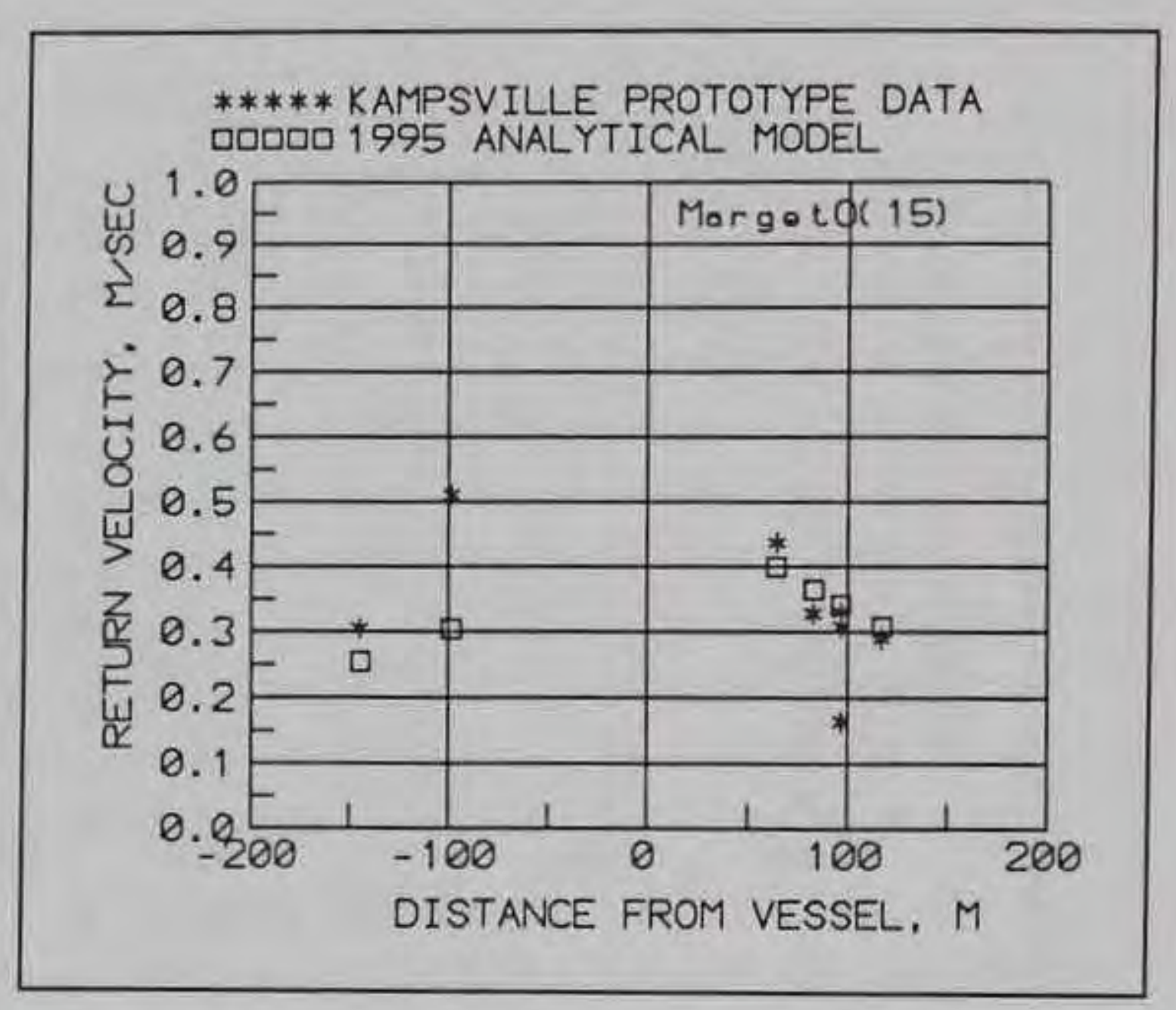

f. $M / V$ Marget $O(15)$ 


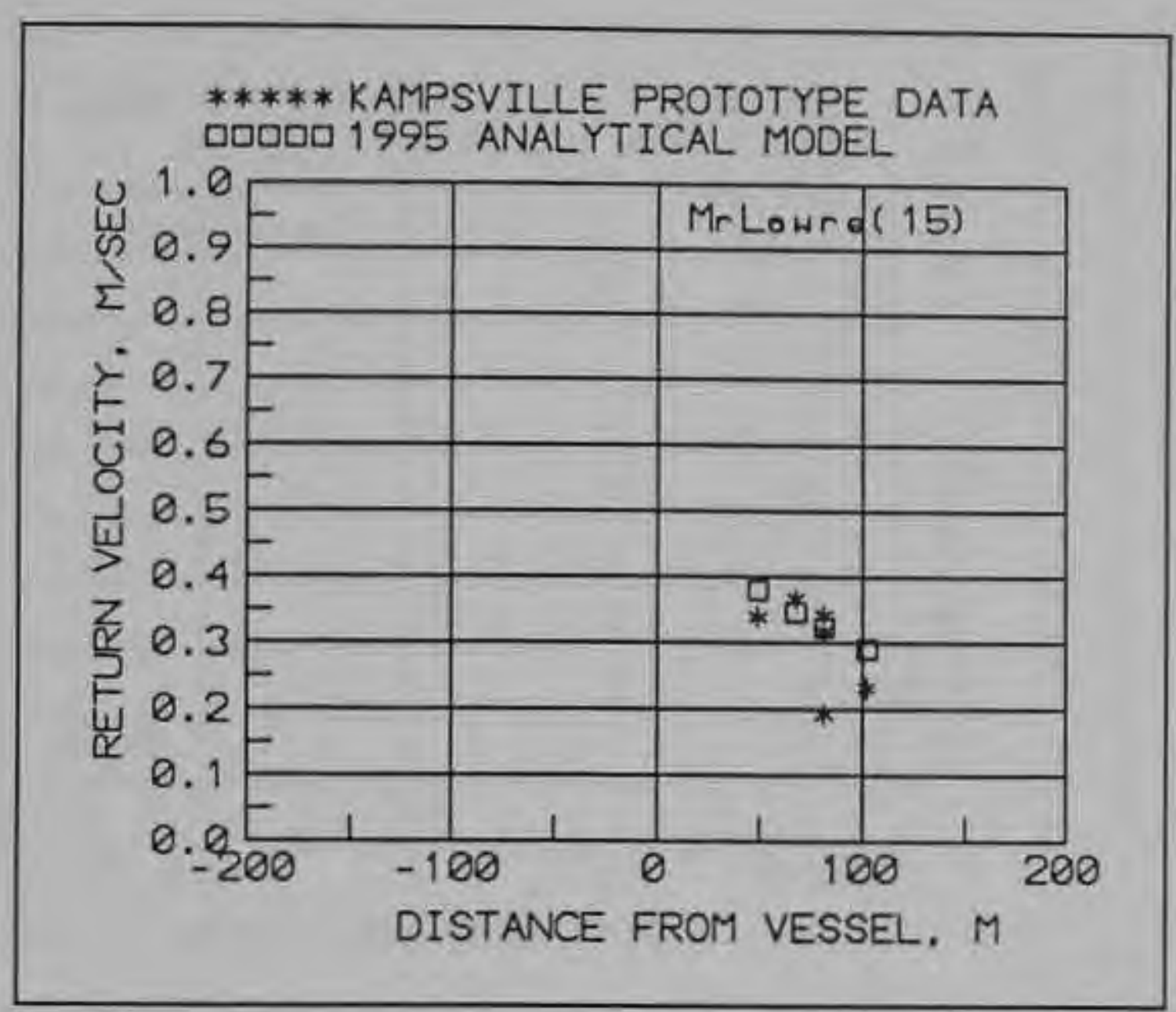

a. M/V Mr. Lawre (15)

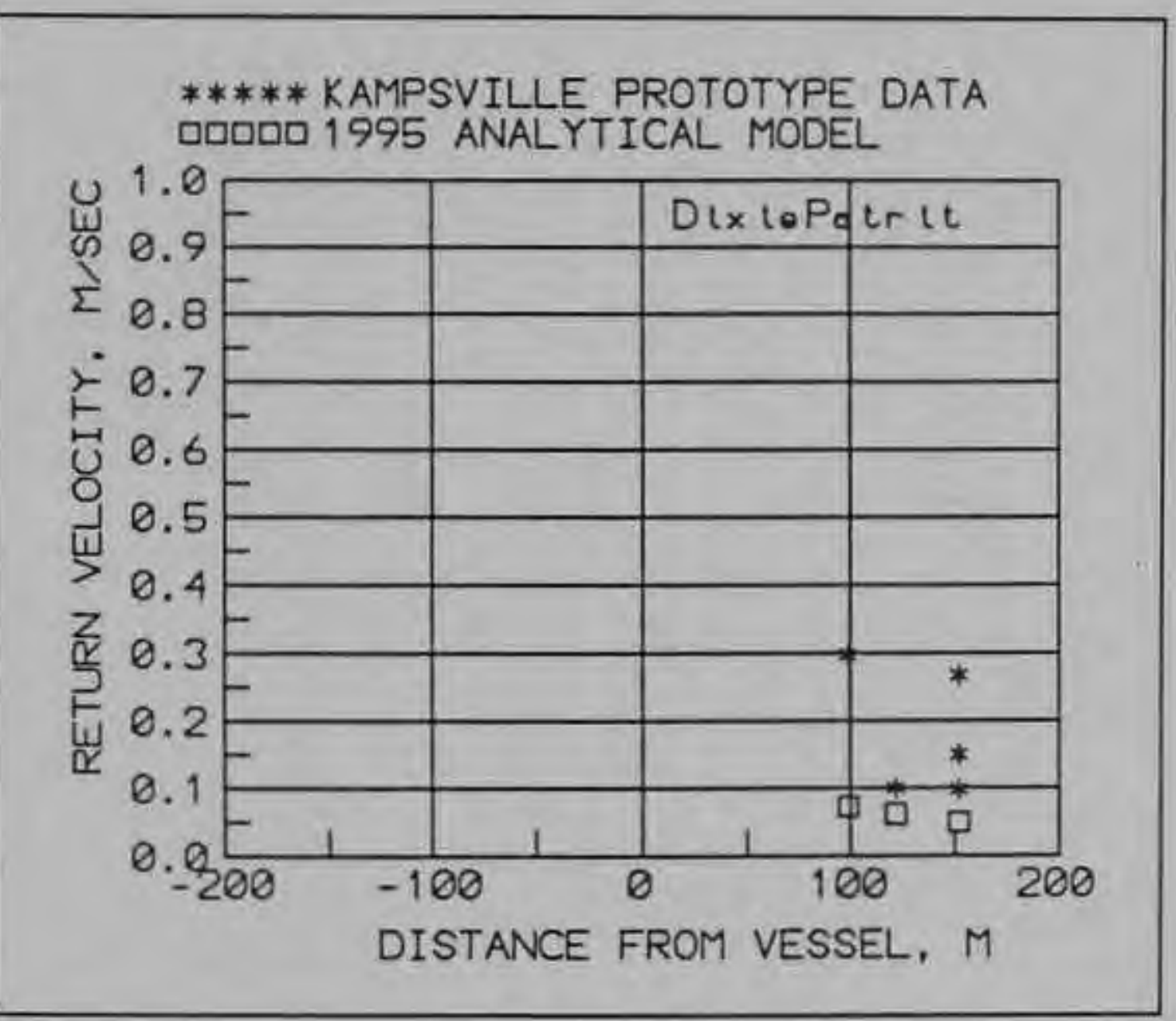

c. M/V Dixie Patrit

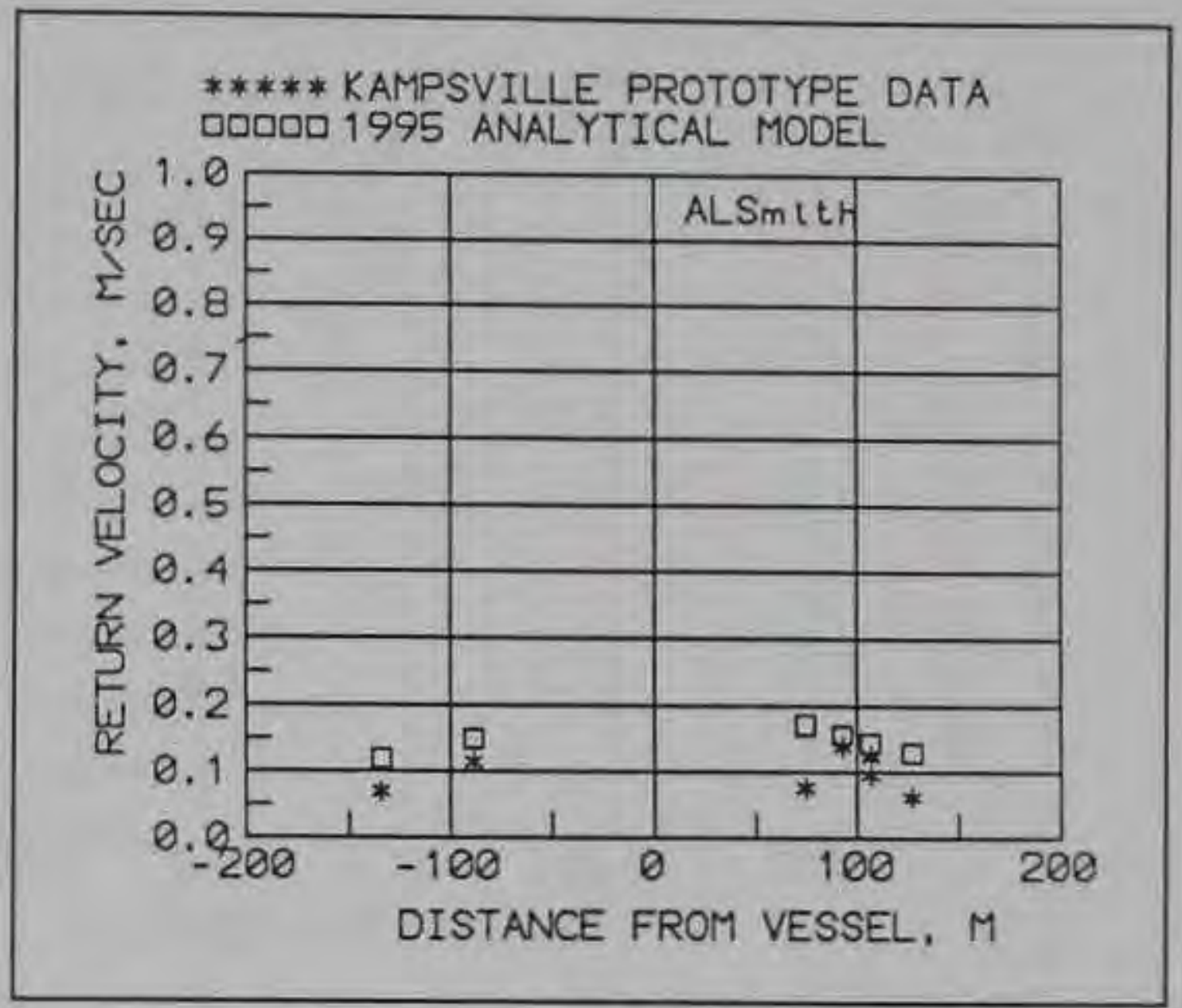

b. M/V Al Smith

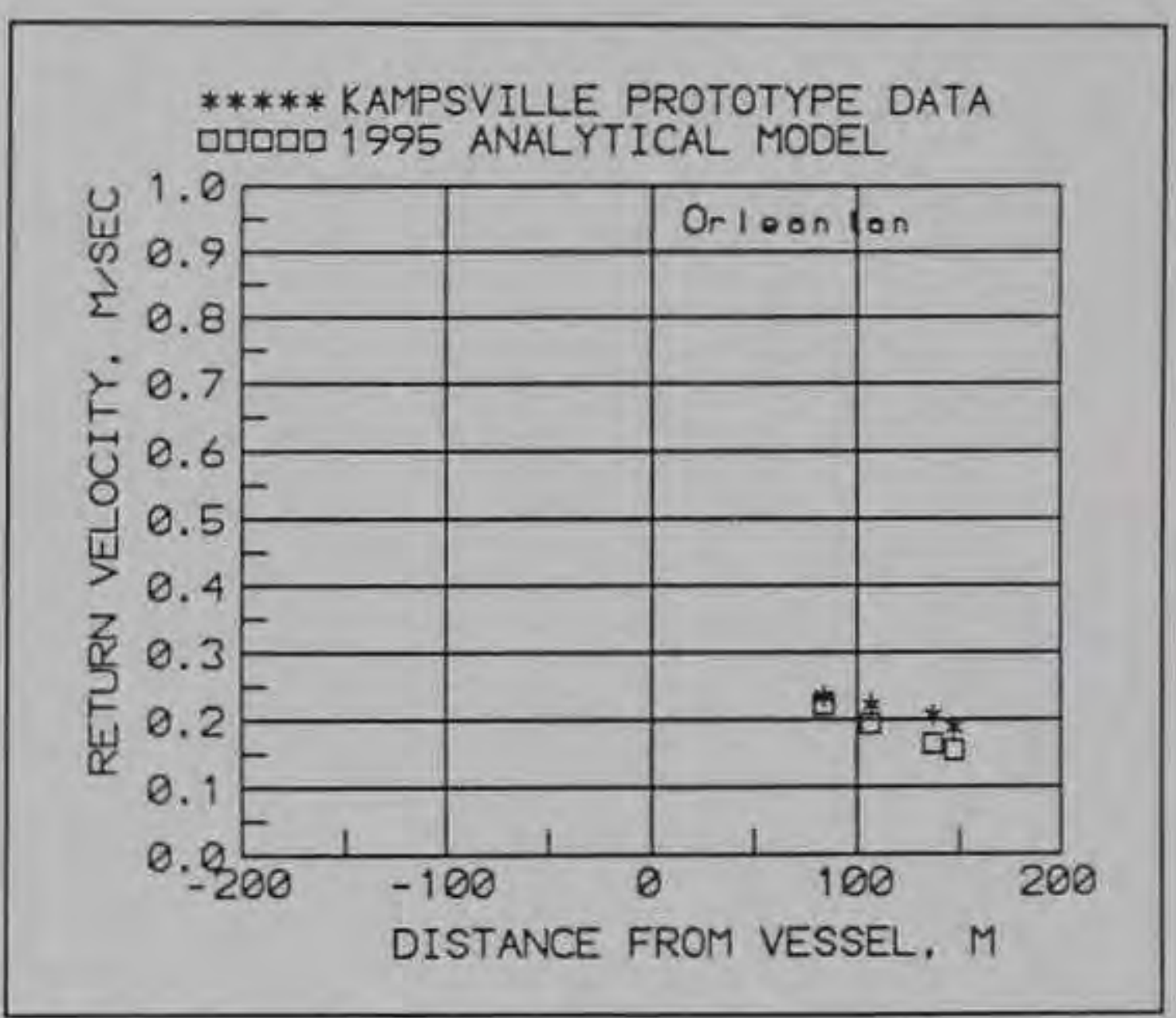

d. M/V Orleanian

Figure 20. Observed Kampsville prototype return velocity versus computed return velocity using 1995 analytical method for individual tests: M/V Mr. Lawre (15), Al Smith, Dixie Patrit, Orleanian, Pat Breen, and Dixie Expre 1 (Continued) 


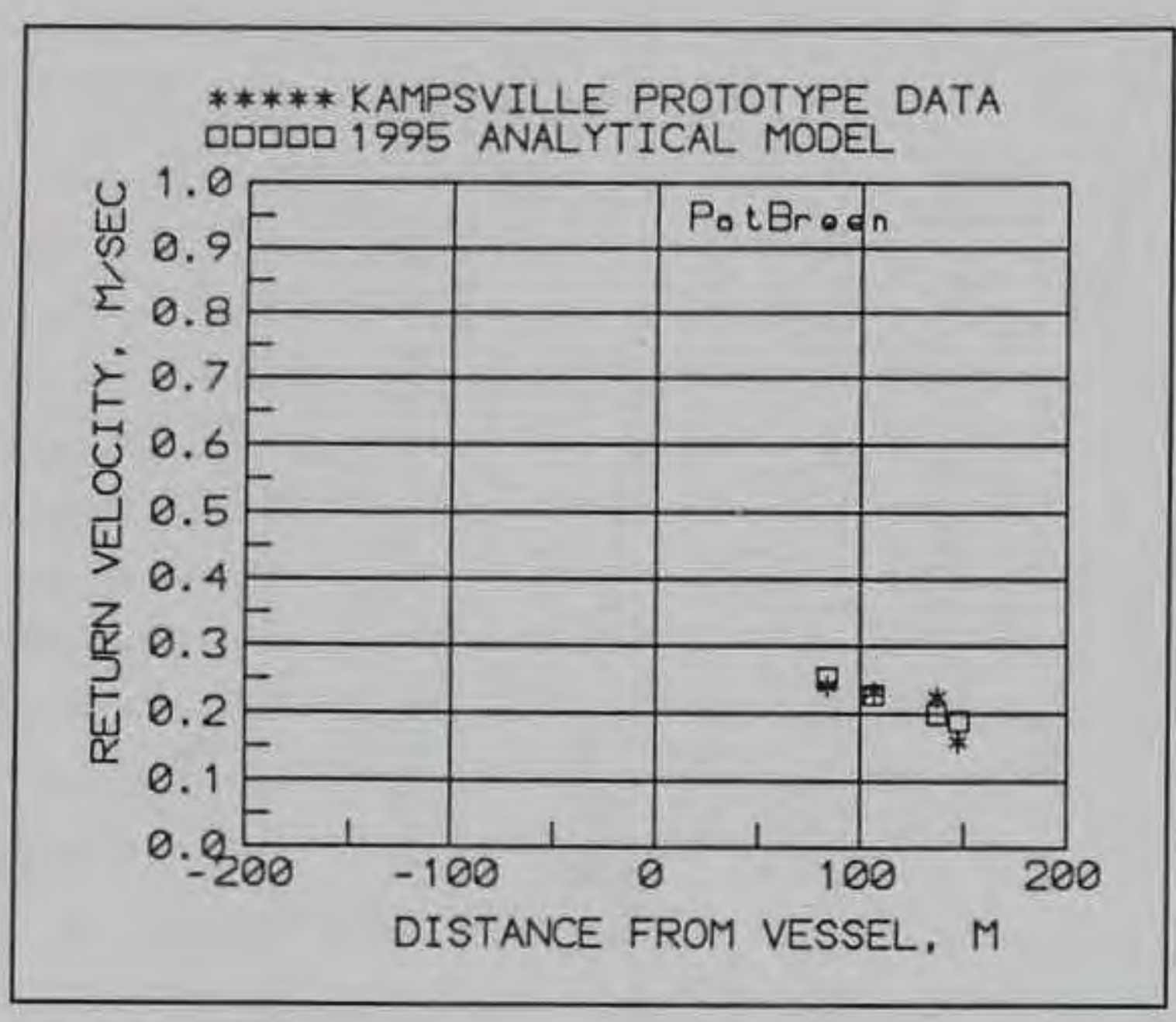

e. M/V Pat Breen

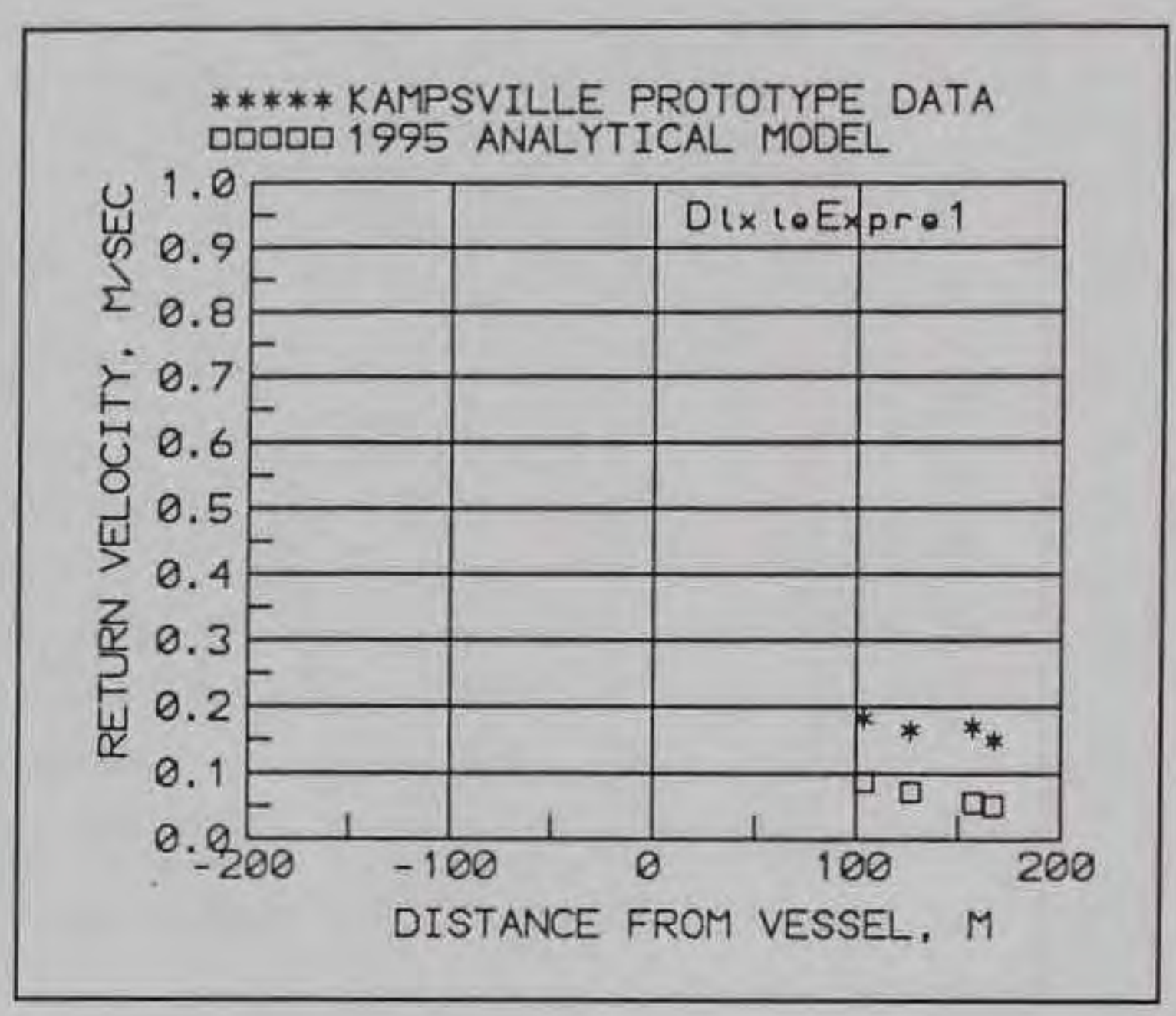

f. $M / V$ Dixie Expre 1

Figure 20. (Concluded) 


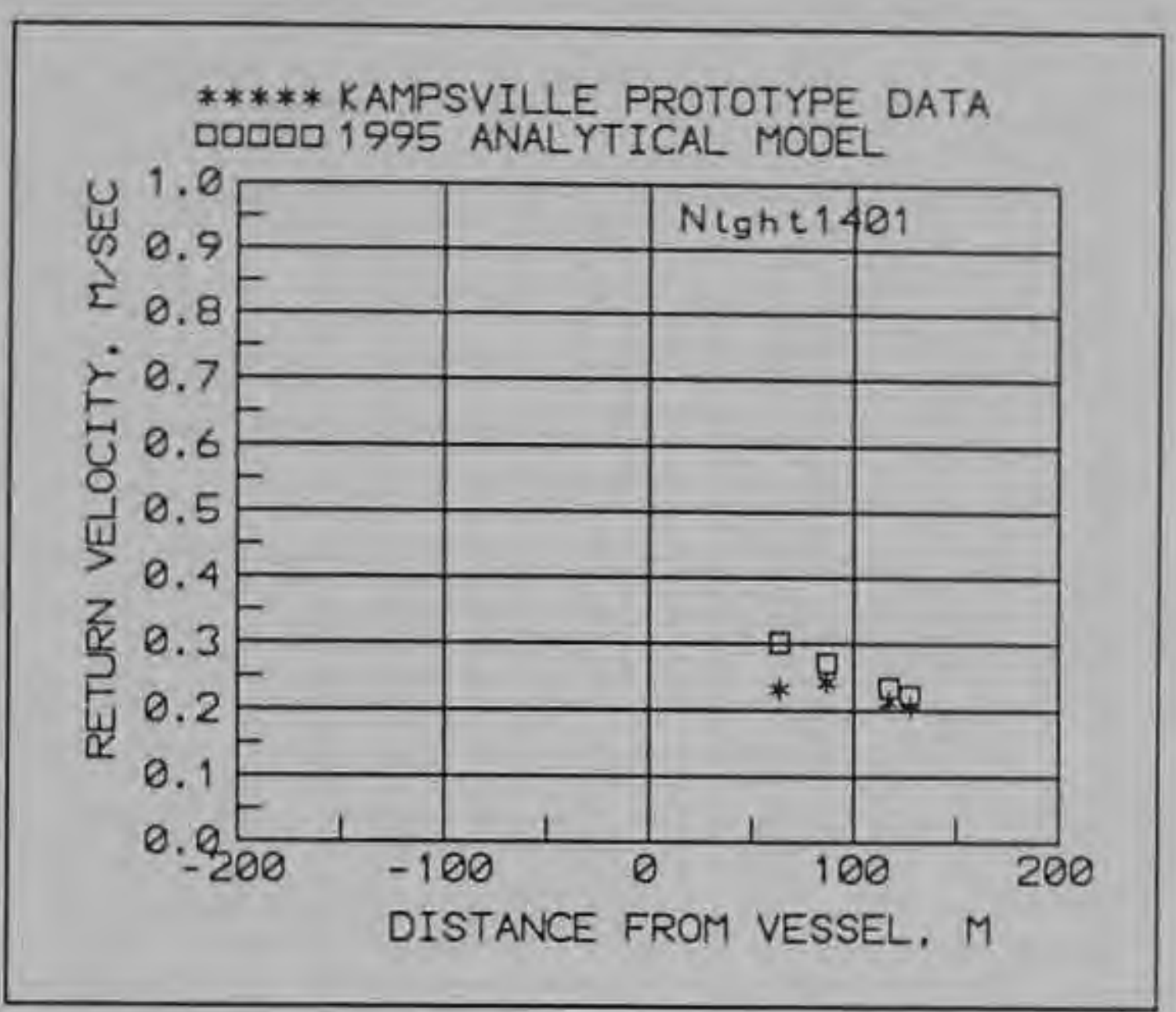

a. M/V Night 1401

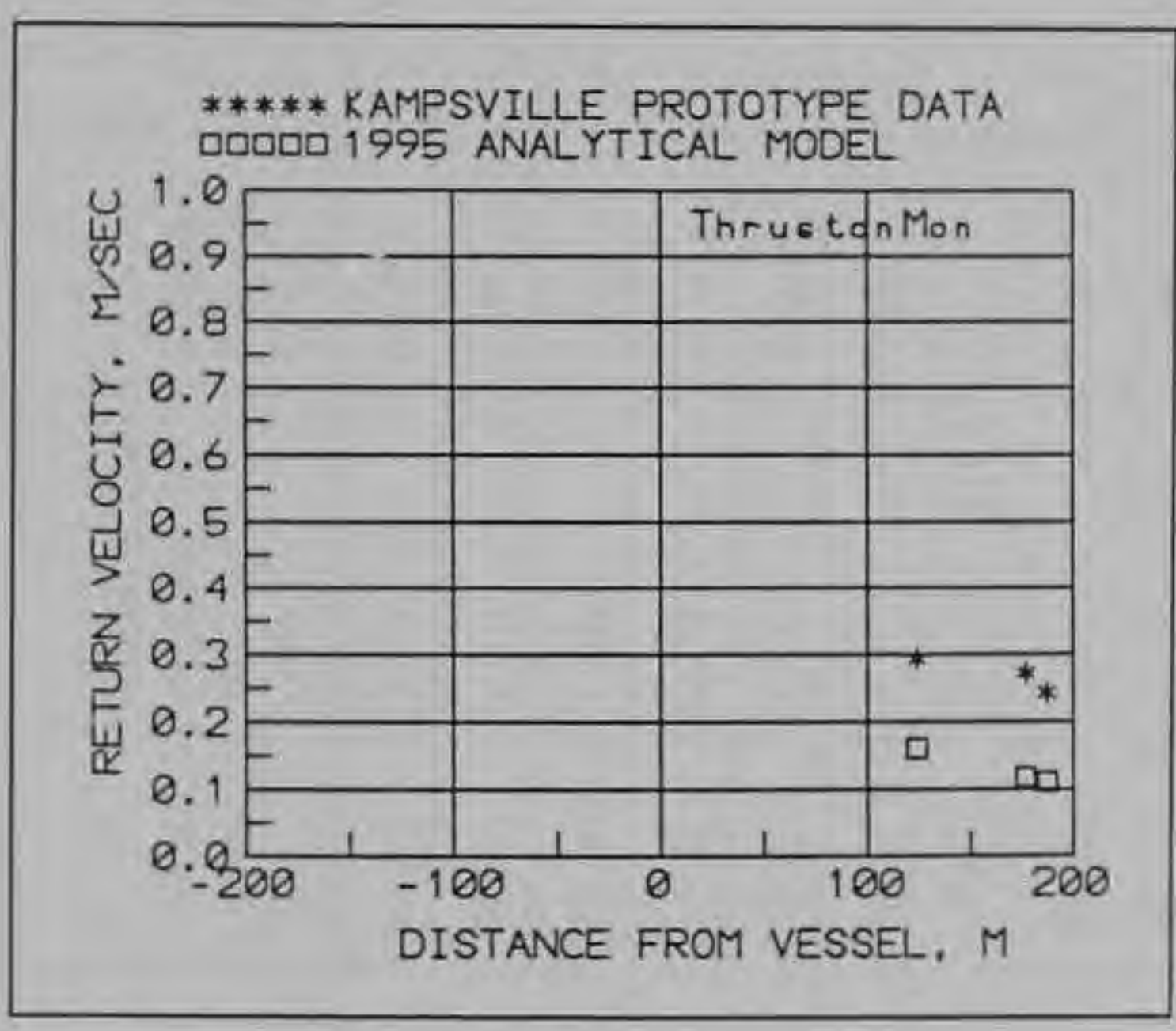

c. M/V Thurston Mon

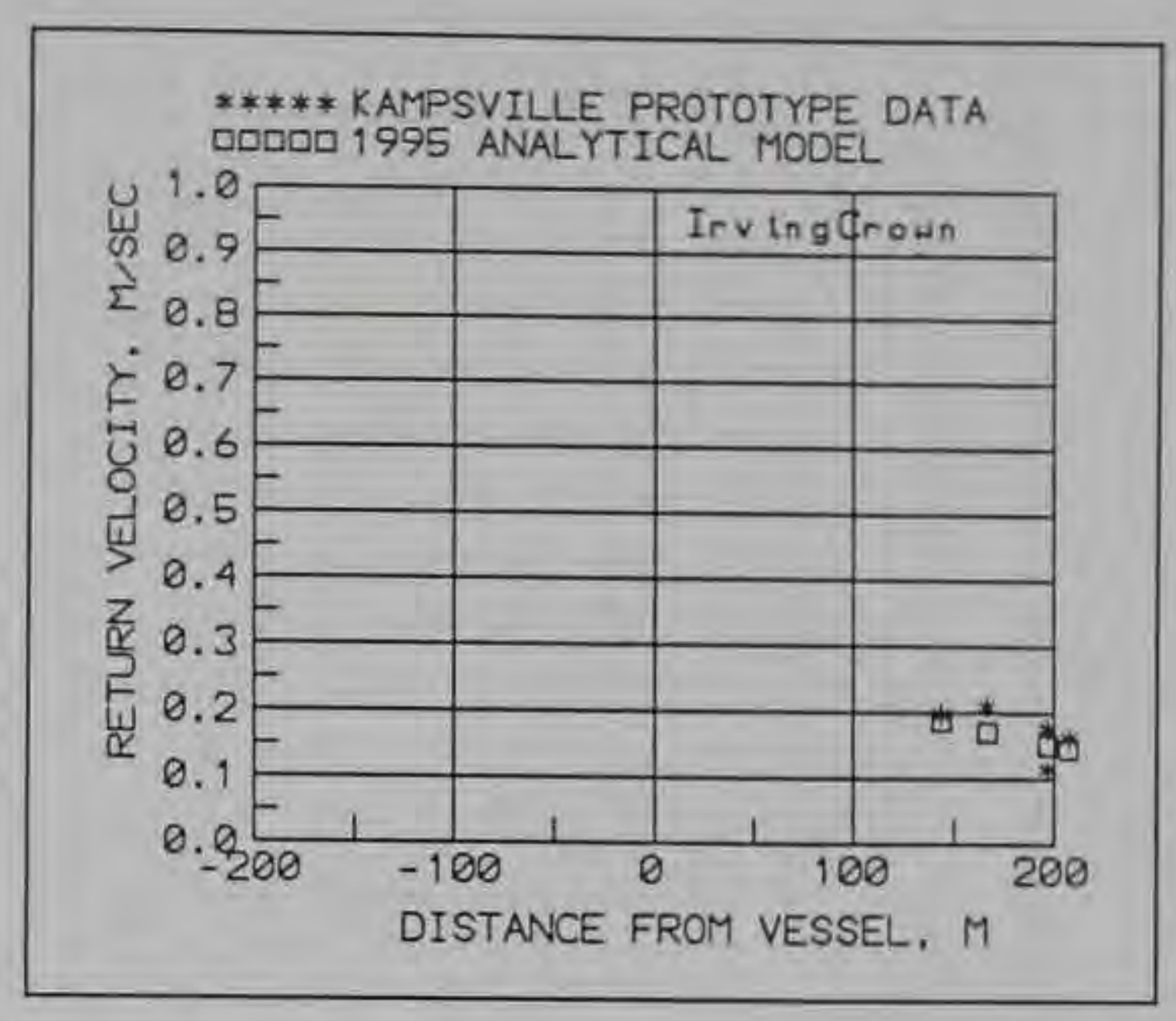

b. M/V Irving Crown

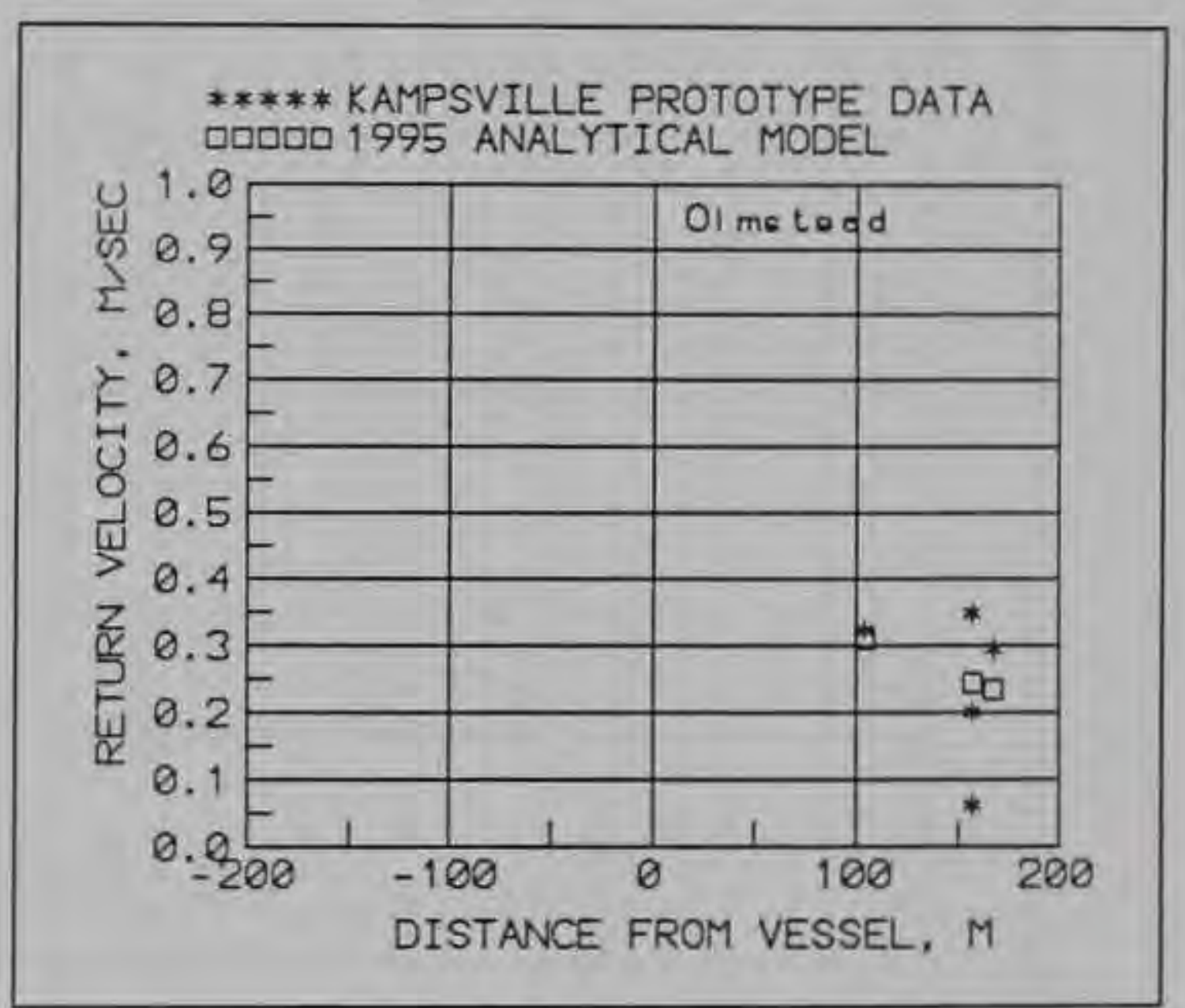

d. M/V Olmstead

Figure 21. Observed Kampsville prototype return velocity versus computed return velocity using 1995 analytical method for individual tests: M/V Night 1401, Irving Crown, Thurston Mon, Olmstead, Jack D. Wofford, and Díxie Expre 2 (Continued) 


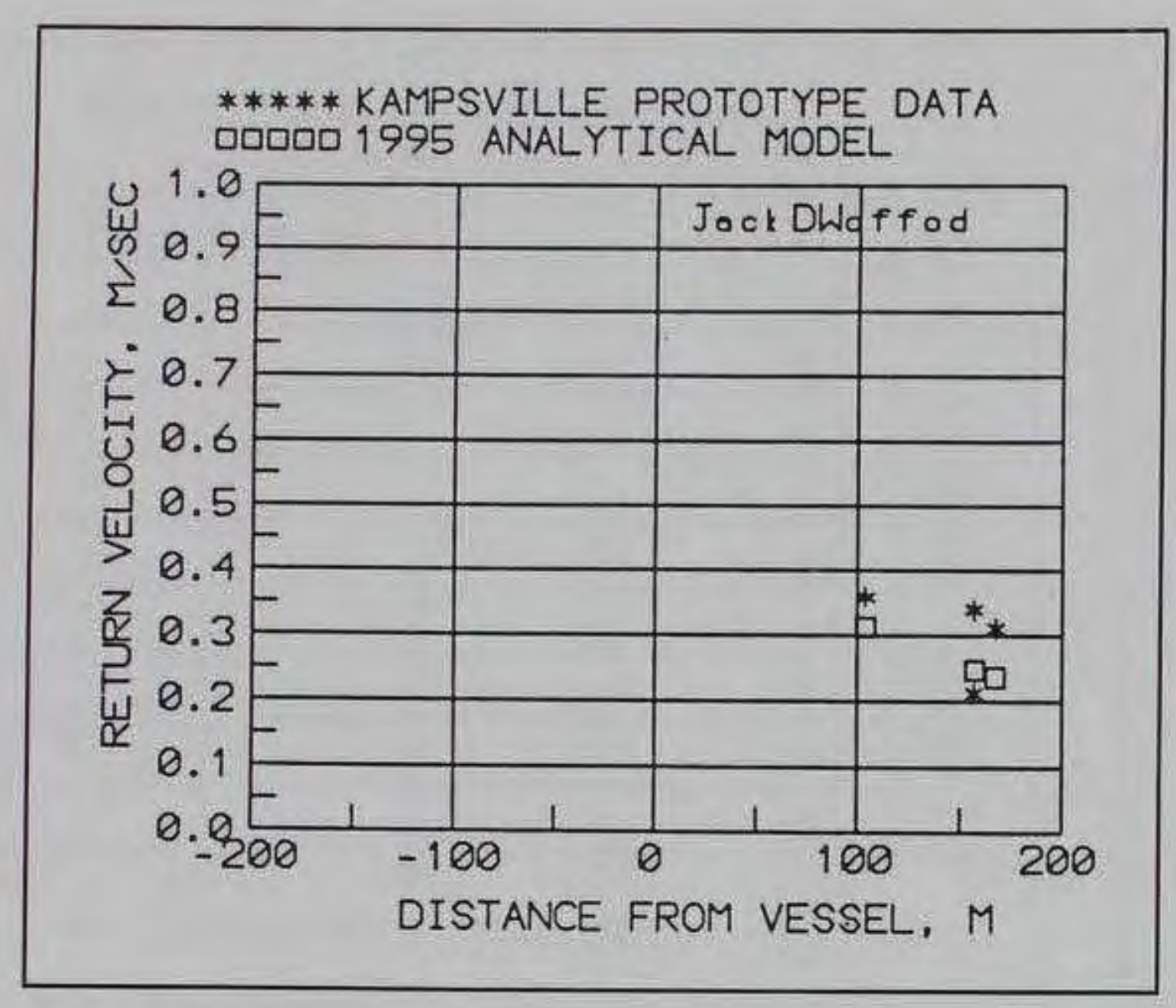

e. M/V Jack D. Woffod

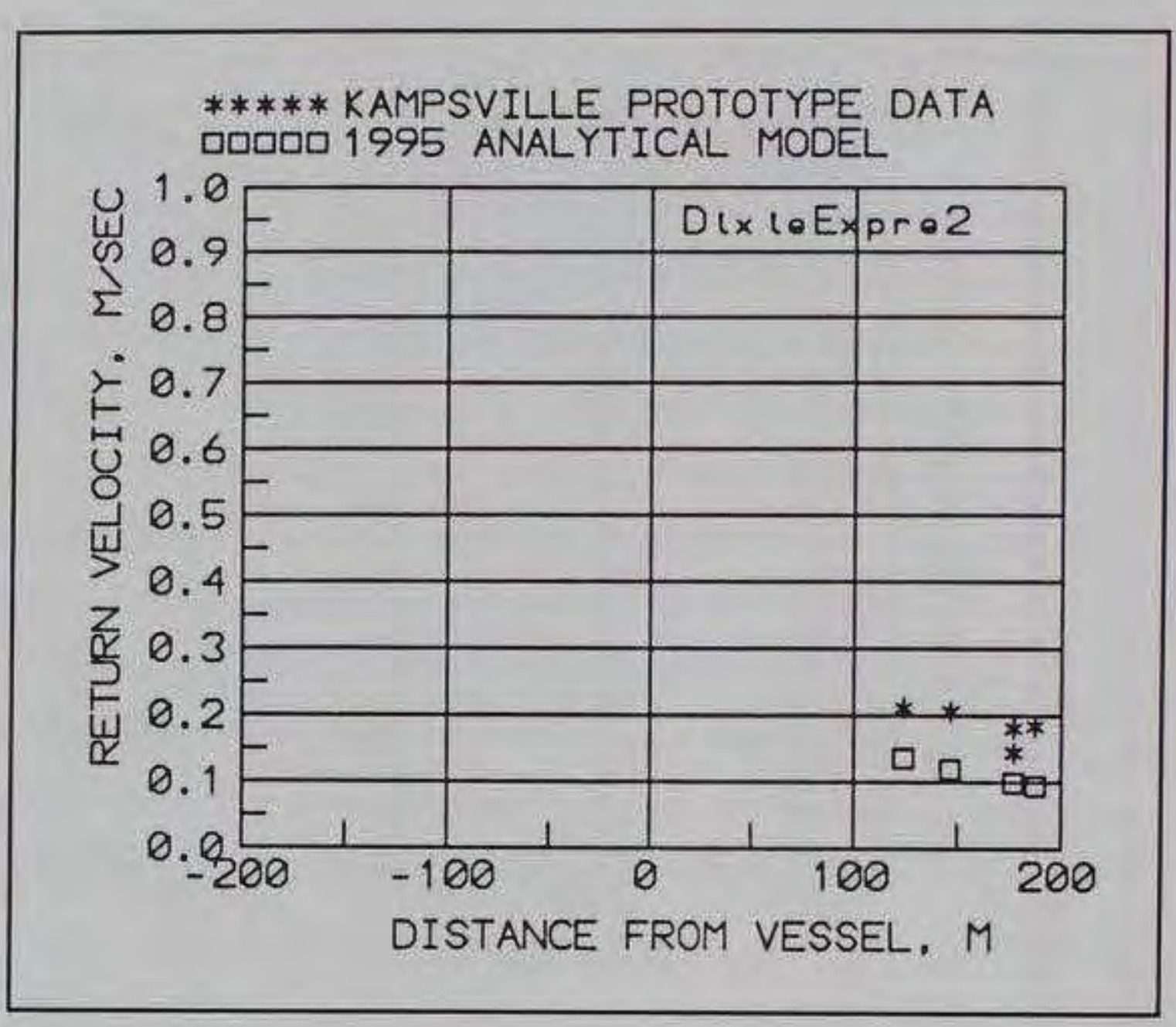

f. $M / V$ Dixie Expre 2

Figure 21. (Concluded) 


\begin{tabular}{|c|c|c|c|c|c|c|c|c|c|c|c|}
\hline \multicolumn{12}{|c|}{$\begin{array}{l}\text { Table } 2 \\
\text { Kampsville Prototype Experimental Conditions }\end{array}$} \\
\hline Test Number & $\begin{array}{l}\text { Vessel } \\
\text { Beam, m } \\
\end{array}$ & $\begin{array}{l}\text { Total } \\
\text { Length of } \\
\text { Barges, } m \\
\end{array}$ & $\begin{array}{l}\text { Effective } \\
\text { Draft, } m\end{array}$ & $\begin{array}{l}\text { Vessel } \\
\text { Power, } \\
\text { Hp }\end{array}$ & $\begin{array}{l}\text { Vessel Speed } \\
\text { Relative to } \\
\text { Ground, } \\
\mathrm{m} / \mathrm{sec} \\
\end{array}$ & $\begin{array}{l}\text { Ambient } \\
\text { Velocity, } \\
\mathrm{m} / \mathrm{sec} \\
\end{array}$ & $\begin{array}{l}\text { Direction, } \\
1=\text { Upbound } \\
2 \text { = Downbound }\end{array}$ & $\begin{array}{l}\text { Channel } \\
\text { Area } \\
\text { Left of } \\
\text { Vessel, } \\
\mathrm{m}^{2} \\
\end{array}$ & $\begin{array}{l}\text { Distance } \\
\text { from Left } \\
\text { Bank to } \\
\text { Vessel m }\end{array}$ & $\begin{array}{l}\text { Total } \\
\text { Channel } \\
\text { Area, } \\
\mathrm{m}^{2}\end{array}$ & $\begin{array}{l}\text { Total } \\
\text { Channel } \\
\text { Width, } m\end{array}$ \\
\hline MrAldo & 32.00 & 297.3 & 2.74 & 5600. & 2.78 & 0.45 & -1. & 783.6 & 230.0 & 1244.4 & 355.1 \\
\hline FloydBlaske & 32.00 & 237.8 & 2.03 & 5000 & 2.18 & 0.45 & 1. & 816.3 & 245.0 & 1244.4 & 355.1 \\
\hline Sugarl(13) & 32.00 & 237.8 & 2.29 & 3375. & 1.88 & 0.49 & 1. & 705.7 & 190.0 & 1309.1 & 358.8 \\
\hline WCNorm(13) & 32.00 & 237.8 & 2.74 & 1800. & 2.90 & 0.49 & -1. & 800.2 & 222.0 & 1309.1 & 358.8 \\
\hline ContiKarla & 32.00 & 297.3 & 2.74 & 3060. & 1.70 & 0.49 & 1. & 775.0 & 215.0 & 1309.1 & 358.8 \\
\hline Rambler & 32.00 & 237.8 & 2.74 & 2000 & 2.48 & 0.54 & -1. & 718.5 & 222.0 & 1320.0 & 359.4 \\
\hline MLawrce(14) & 32.00 & 237.8 & 2.03 & 5600. & 2.56 & 0.54 & 1. & 711.9 & 195.0 & 1320.0 & 359.4 \\
\hline ChaLehmen & 32.00 & 237.8 & 2.74 & 5600. & 1.85 & 0.54 & 1. & 784.6 & 215.0 & 1320.0 & 359.4 \\
\hline Jeffboat & 32.00 & 297.5 & 2.74 & 6000. & 1.84 & 0.54 & 1. & 875.0 & 245.0 & 1320.0 & 359.4 \\
\hline ArdyceRandl & 32.00 & 297.5 & 2.74 & 5600. & 2.36 & 0.56 & -1. & 737.7 & 205.0 & 1331.0 & 360.0 \\
\hline MrPaul(15) & 32.00 & 178.4 & 2.27 & 5600. & 2.25 & 0.56 & 1. & 840.7 & 230.0 & 1331.0 & 360.0 \\
\hline MargetO(15) & 32.00 & 178.4 & 2.51 & 5600. & 3.83 & 0.56 & -1. & 840.7 & 230.0 & 1331.0 & 360.0 \\
\hline MrLawre(15) & 32.00 & 297.5 & 2.74 & 5600. & 3.16 & 0.56 & -1. & 862.7 & 245.0 & 1331.0 & 360.0 \\
\hline ALSmith & 21.34 & 237.8 & 2.74 & 1800 & 2.80 & 0.57 & -1. & 868.9 & 220.0 & 1342.0 & 360.6 \\
\hline DixiePatrit & 10.67 & 178.4 & 2.74 & 3200. & 2.48 & 0.29 & -1 & 424.5 & 145,0 & 1118.9 & 320.0 \\
\hline Orleanian & 32.00 & 237.8 & 2.03 & 4300. & 2.02 & 0.29 & 1. & 484.5 & 160.0 & 1118.9 & 320.0 \\
\hline PatBreen & 32.00 & 297.3 & 2.74 & 5600. & 2.29 & 0.29 & -1. & 484.5 & 160.0 & 1118.9 & 320.0 \\
\hline DixieExpre1 & 15.90 & 160.0 & 1.52 & 1700 & 3.40 & 0.29 & -1. & 404.7 & 140.0 & 1118.9 & 320.0 \\
\hline Night1401 & 32.00 & 237.8 & 2.74 & 9999. & 1.62 & 0.29 & 1. & 560.8 & 180.0 & 1118.9 & 320.0 \\
\hline & & & & & & & & & & & (Continued) \\
\hline
\end{tabular}




\begin{tabular}{|c|c|c|c|c|c|c|c|c|c|c|c|}
\hline \multicolumn{12}{|c|}{ Table 2 (Concluded) } \\
\hline Test Number & $\begin{array}{l}\text { Vessel } \\
\text { Beam, } \mathbf{m}\end{array}$ & $\begin{array}{l}\text { Total } \\
\text { Length of } \\
\text { Barges, } m\end{array}$ & $\begin{array}{l}\text { Effective } \\
\text { Draft, } m\end{array}$ & $\begin{array}{l}\text { Vessel } \\
\text { Power, } \\
\text { Hp }\end{array}$ & $\begin{array}{l}\text { Vessel Speed } \\
\text { Relative to } \\
\text { Ground, } \\
\mathrm{m} / \mathrm{sec}\end{array}$ & $\begin{array}{l}\text { Ambient } \\
\text { Velocity, } \\
\mathrm{m} / \mathrm{sec}\end{array}$ & $\begin{array}{l}\text { Direction, } \\
1=\text { Upbound } \\
2=\text { Downbound }\end{array}$ & $\begin{array}{l}\text { Channel } \\
\text { Area } \\
\text { Left of } \\
\text { Vessel, } \\
\mathrm{m}^{2}\end{array}$ & $\begin{array}{l}\text { Distance } \\
\text { from Left } \\
\text { Bank to } \\
\text { Vessel m }\end{array}$ & $\begin{array}{l}\text { Total } \\
\text { Channel } \\
\text { Area, } \\
\mathrm{m}^{2}\end{array}$ & $\begin{array}{l}\text { Total } \\
\text { Channel } \\
\text { Width, } m\end{array}$ \\
\hline Irving Crown & 32.00 & 178.4 & 2.74 & 2400. & 1.59 & 0.29 & 1. & 254.6 & 100.0 & 1118.9 & 320.0 \\
\hline ThrustonMon & 32.00 & 237.8 & 1.63 & 4200. & 2.18 & 0.29 & 1. & 327.9 & 120.0 & 1118.9 & 320.0 \\
\hline Olmstead & 32.00 & 297.3 & 2.74 & 5920. & 2.19 & 0.29 & 1. & 404.7 & 140.0 & 1118.9 & 320.0 \\
\hline JackDWoffod & 32.00 & 297.3 & 2.74 & 5000. & 2.22 & 0.29 & 1. & 404.7 & 140.0 & 1118.9 & 320.0 \\
\hline DixieExpre2 & 15.90 & 160.9 & 2.74 & 1800. & 2.58 & 0.29 & 1. & 327.9 & 120.0 & 1118.9 & 320.0 \\
\hline
\end{tabular}




\section{Development of 1995 Analytical Method for Prediction of Water-Level Drawdown}

To compute water-level drawdown at position $\mathrm{Y}$ from the center line of the vessel, the average return velocity, as determined from Equation 13, was used in Equation 2 to determine the average drawdown $\mathrm{z}$ for the section. The difficulty at this point is that the number of drawdown distributions in the physical model was limited. Therefore, return velocity distributions were used to determine how the drawdown varied on either side of the tow and across the section. The drawdown on either side of the tow was determined from the same equations used for return velocity in Equations 14 and 15. For $B_{\text {side }} / B_{\text {total }}$ from 0 to 0.5

$$
\frac{Z_{r s}}{z}=1.65-1.3 \frac{B_{\text {side }}}{B_{\text {total }}}
$$

For $B_{\text {side }} / B_{\text {toral }}$ from 0.5 to 1.0

$$
\frac{Z_{r s}}{z}=1.35-0.7 \frac{B_{\text {side }}}{B_{\text {total }}}
$$

The maximum drawdown at $(Y-B) /\left(B_{\text {side }}-B\right)=0$ is 


$$
\frac{Z_{s m}}{Z_{r s}}=\alpha_{d r a w}
$$

where $\alpha_{\text {draw }}$ is a function of $\alpha^{\prime}$ defined by Equation 16 .

The distribution of $\mathrm{Z}(\mathrm{Y})$ is defined as

$$
\frac{Z(Y)}{Z_{s m}}=\exp \left[C\left(\frac{Y-B}{B_{\text {side }}-B}\right)\right]
$$

where $Z(Y)$ is the maximum water-level drawdown during the tow event at distance $\mathrm{Y}$ from the vessel center line and $C$ is defined by Equation $17 . \alpha_{\text {draw }}$ is the primary factor that establishes the slope of the drawdown distribution. Based on the Kampsville and Clark's Ferry physical model drawdown data and detailed drawdown measurements for the WC Norman tow in the Kampsville physical model, $\alpha_{\text {draw }}$ is defined by

$$
\alpha_{\text {draw }}=\alpha^{\prime 0.5}
$$

Scatterplots of observed physical model drawdown from Kampsville and Clark's Ferry versus computed drawdown using the 1995 analytical drawdown method are shown in Figures 22 and 23, respectively. Comparison of the analytical method with detailed drawdown data from the WC Norman tow in the Kampsville physical model is shown in Table 3. The physical modelbased 1995 Analytical Drawdown method was then tested for agreement with the prototype data which was taken at a single-wave gauge at the Kampsville site on the Illinois River. The wave data from ISWS were collected at 10 samples/sec. To be consistent with the return velocity analysis, an 11-sec moving average was used to smooth the wave data before extracting the ambient and changed water level from the record. Drawdown measurements based on only a staff gage reading were not used in this comparison. A scatterplot of drawdown for the ISWS prototype data is shown in Figure 24. 


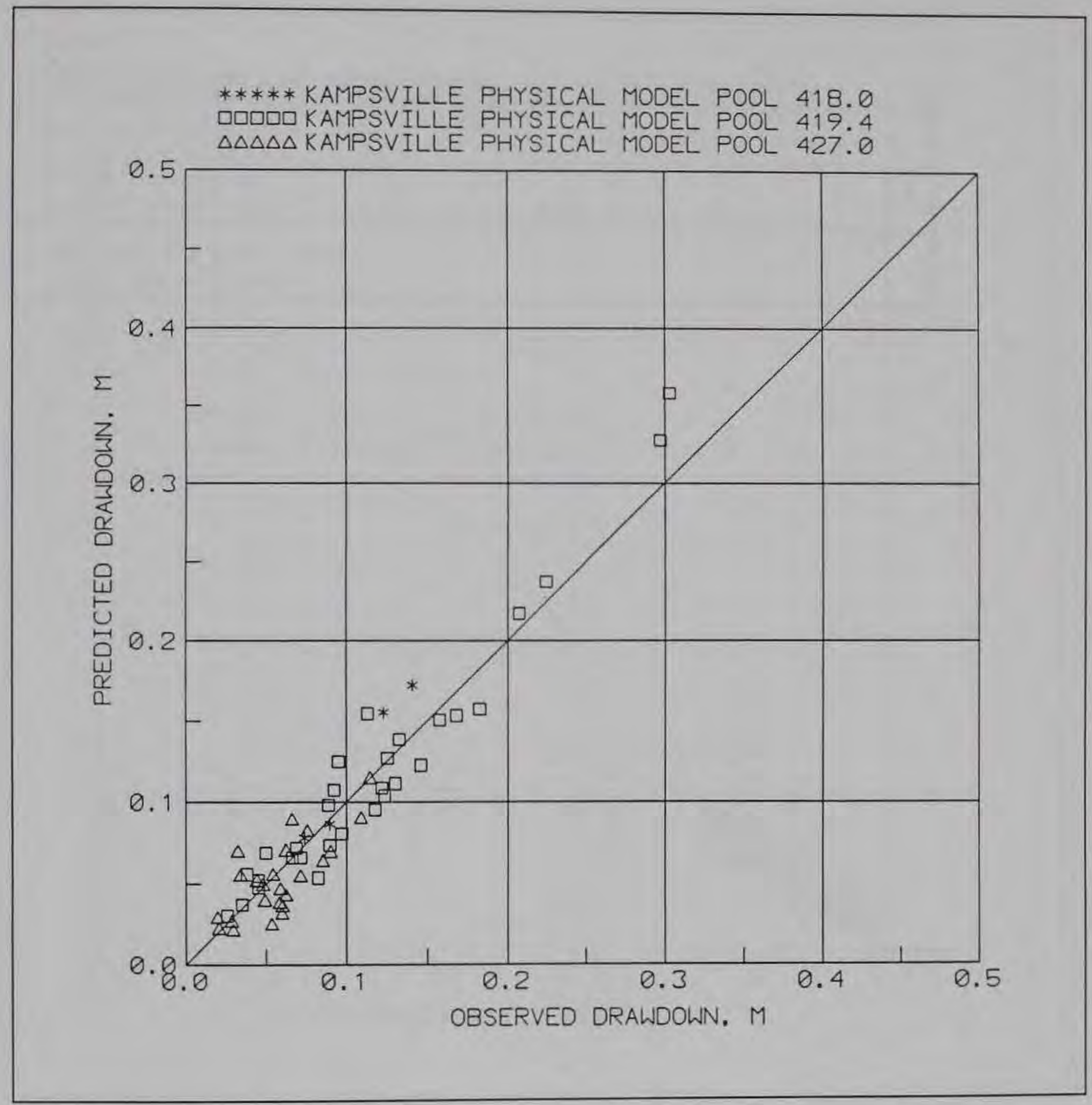

Figure 22. Observed Kampsville physical model drawdown versus computed drawdown using 1995 analytical method 


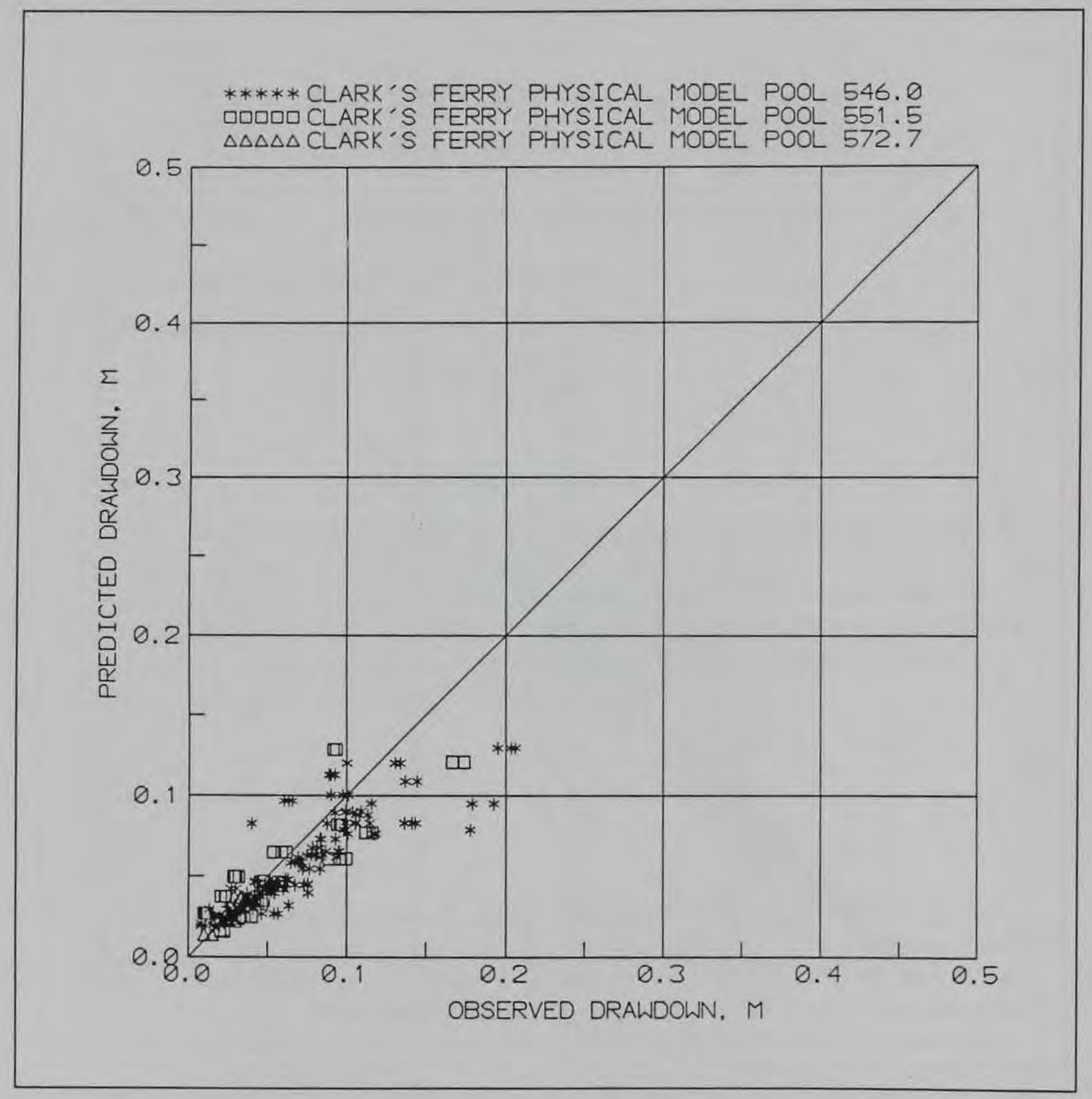

Figure 23. Observed Clark's Ferry physical model drawdown versus computed drawdown using 1995 analytical method 


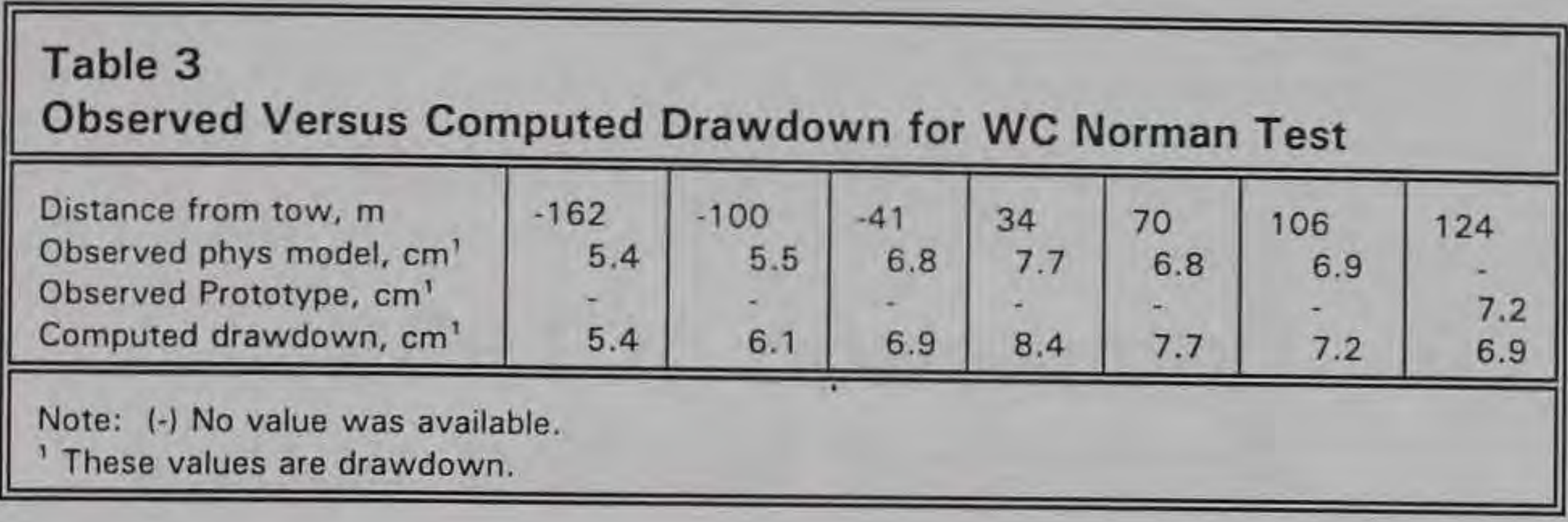

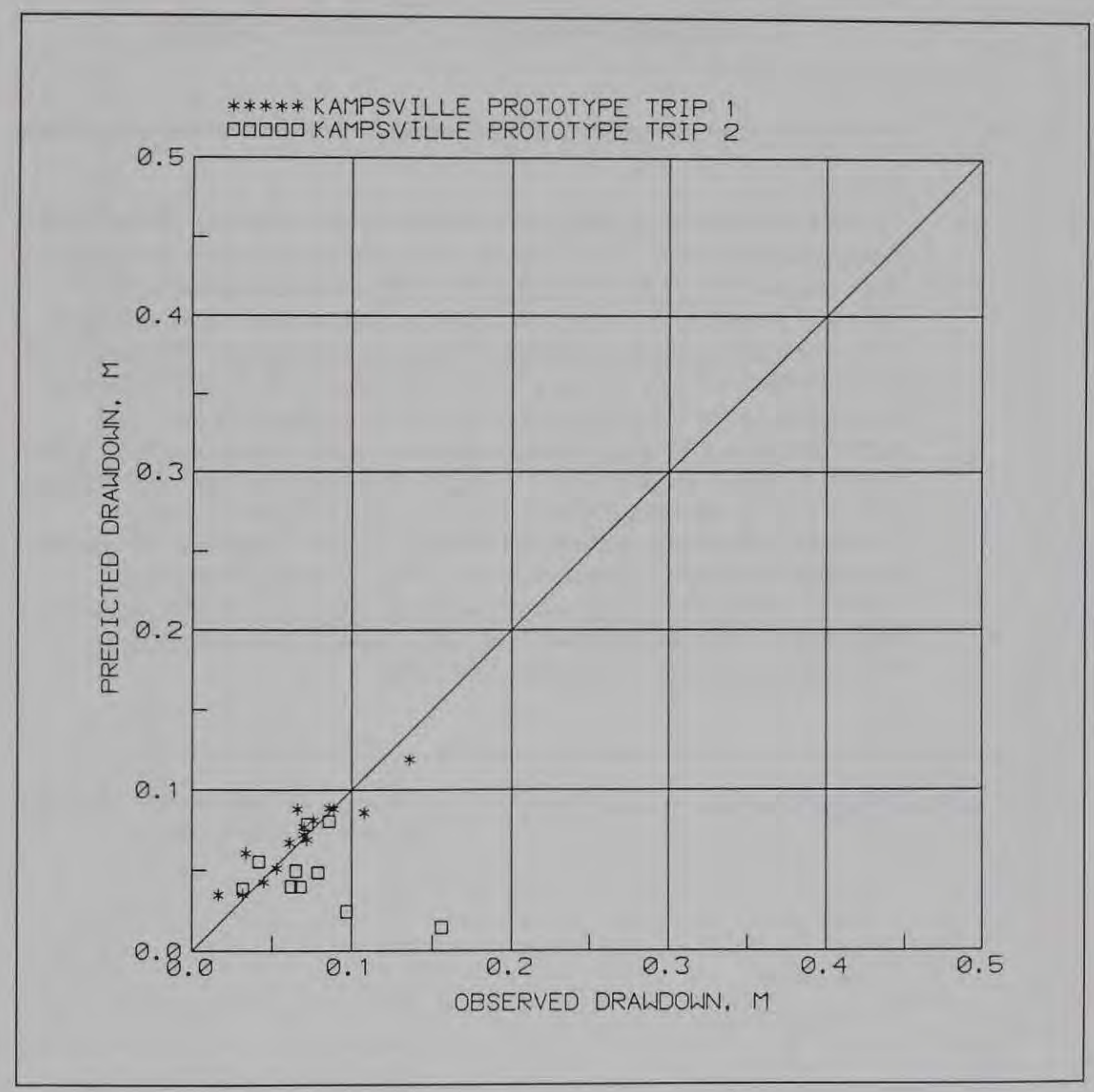

Figure 24. Observed Kampsville prototype drawdown versus computed drawdown using 1995 analytical method 


\section{Comparison of 1995 Analytical Method with Independent Field Data}

Since the Kampsville and Clark's Ferry field data were used to verify the Kampsville and Clark's Ferry physical models which were then used to produce data used in the development of the 1995 method, comparison of the analytical method to the same field data is not independent. Two field data sets were used to provide an independent comparison with the 1995 analytical method. The first data set was return velocity data taken by ESE (1981) at one section on the Mississippi River and one on the Illinois River. A scatterplot of all ESE return velocity data meeting the limitations of the 1995 method is shown in Figure 25. The second data set comes from data collected at four sites on the Ohio River by the U.S. Army Engineer District, Louisville, whose cross sections are shown in Figures 26 through 29 and data on Tables 4 through 7. Scatterplots for all four sections are shown in Figures 30 and 31 for return velocity and drawdown, respectively. Scatter is large, but the trend around the line of perfect agreement is correct for all three scatterplots. 


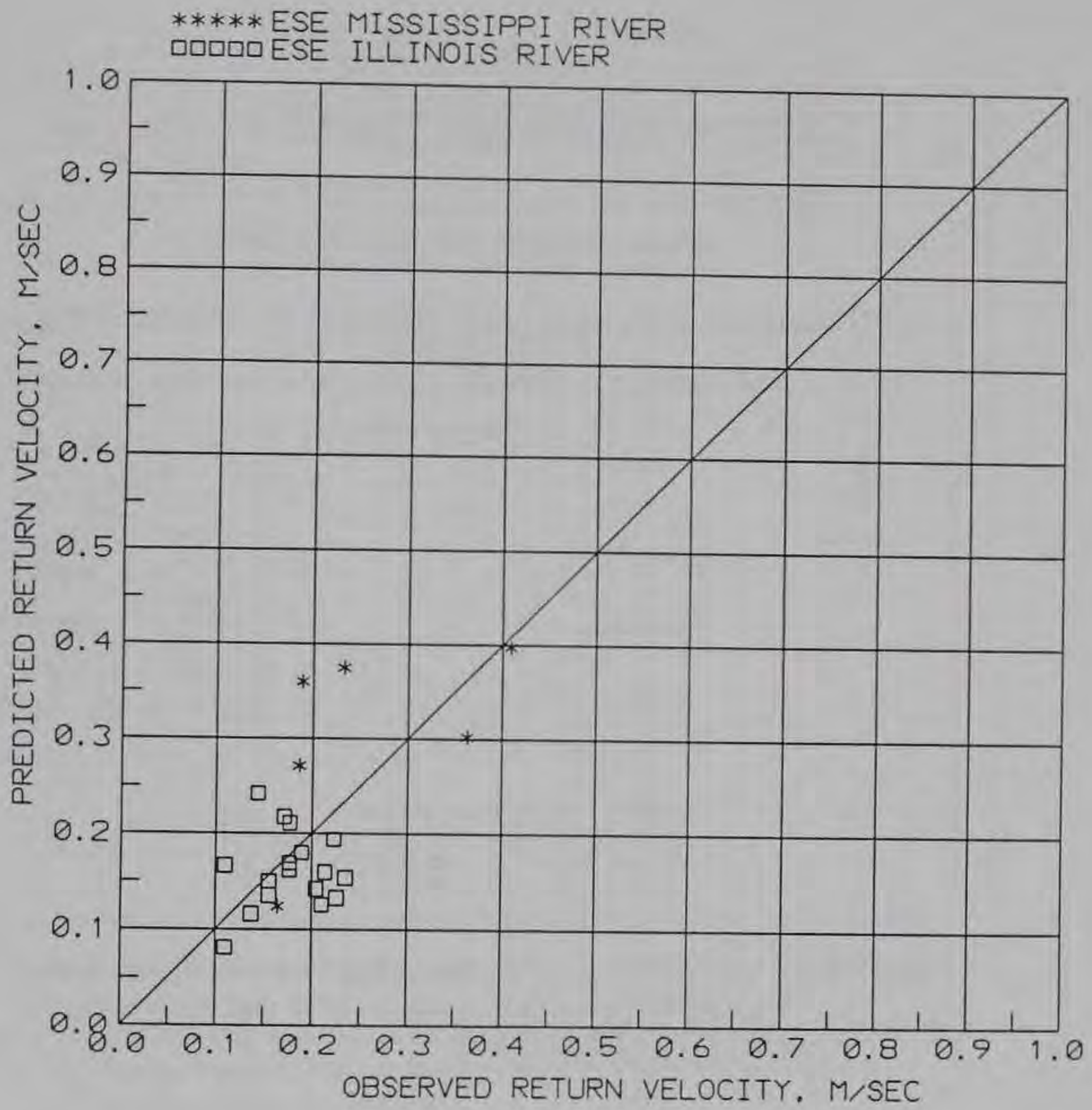

Figure 25. Observed ESE prototype return velocity versus computed return velocity using 1995 analytical method 


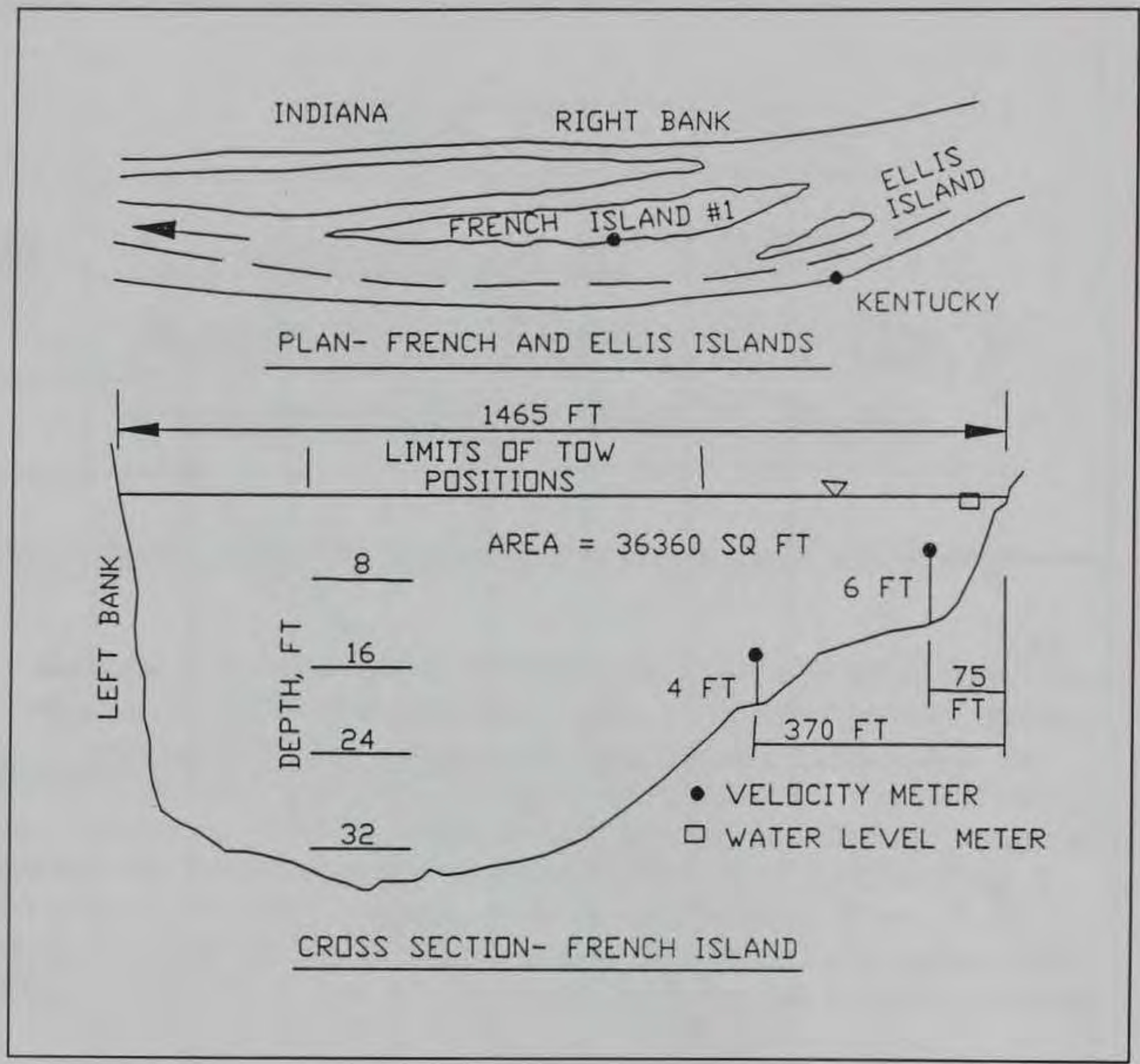

Figure 26. Cross section for ORL tests 89192-89196, French Island (Factor for converting feet to metric is 3.048 and square feet to square meters is 0.0929 ) 

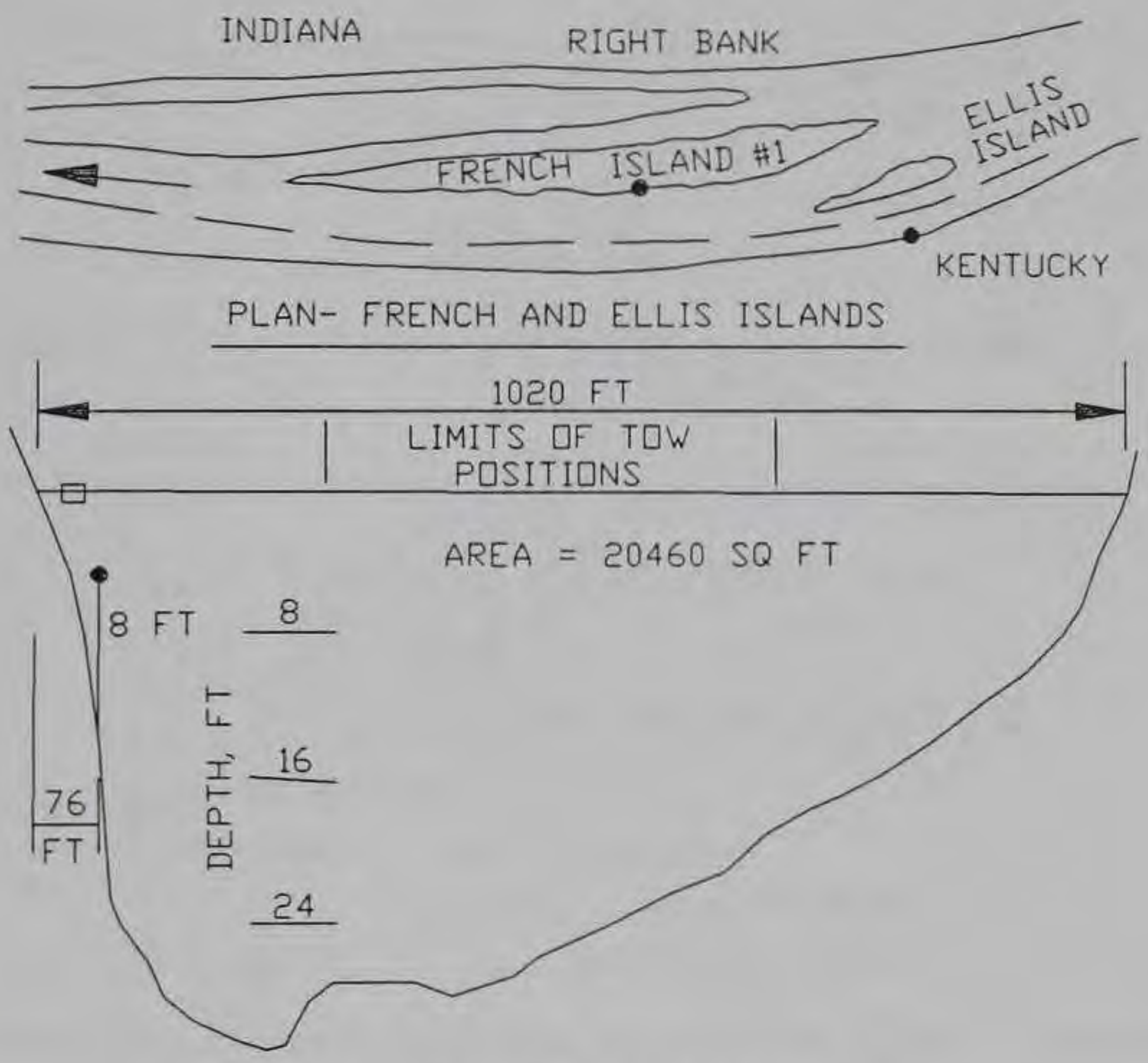

CRISS SECTION- ELLIS ISLAND

Figure 27. Cross section for ORL tests 89198-89203 - Ellis Island (Factor for converting feet to meters is 3.048 and square feet to square meters is 0.0929 ) 


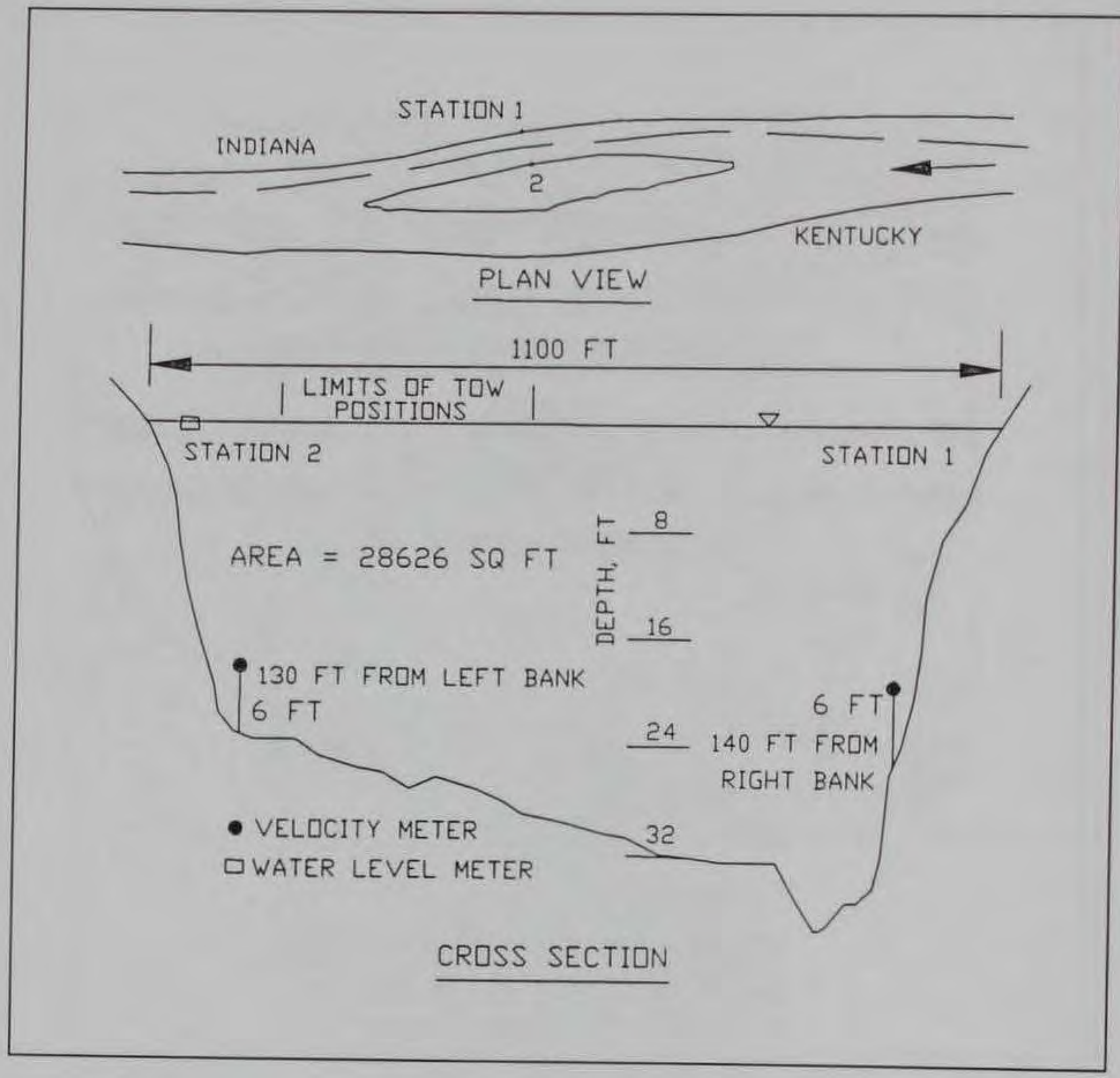

Figure 28. Cross section for ORL tests 90172-90179 (Factor for converting feet to meters is 3.048 and square feet to square meters is 0.0929) 


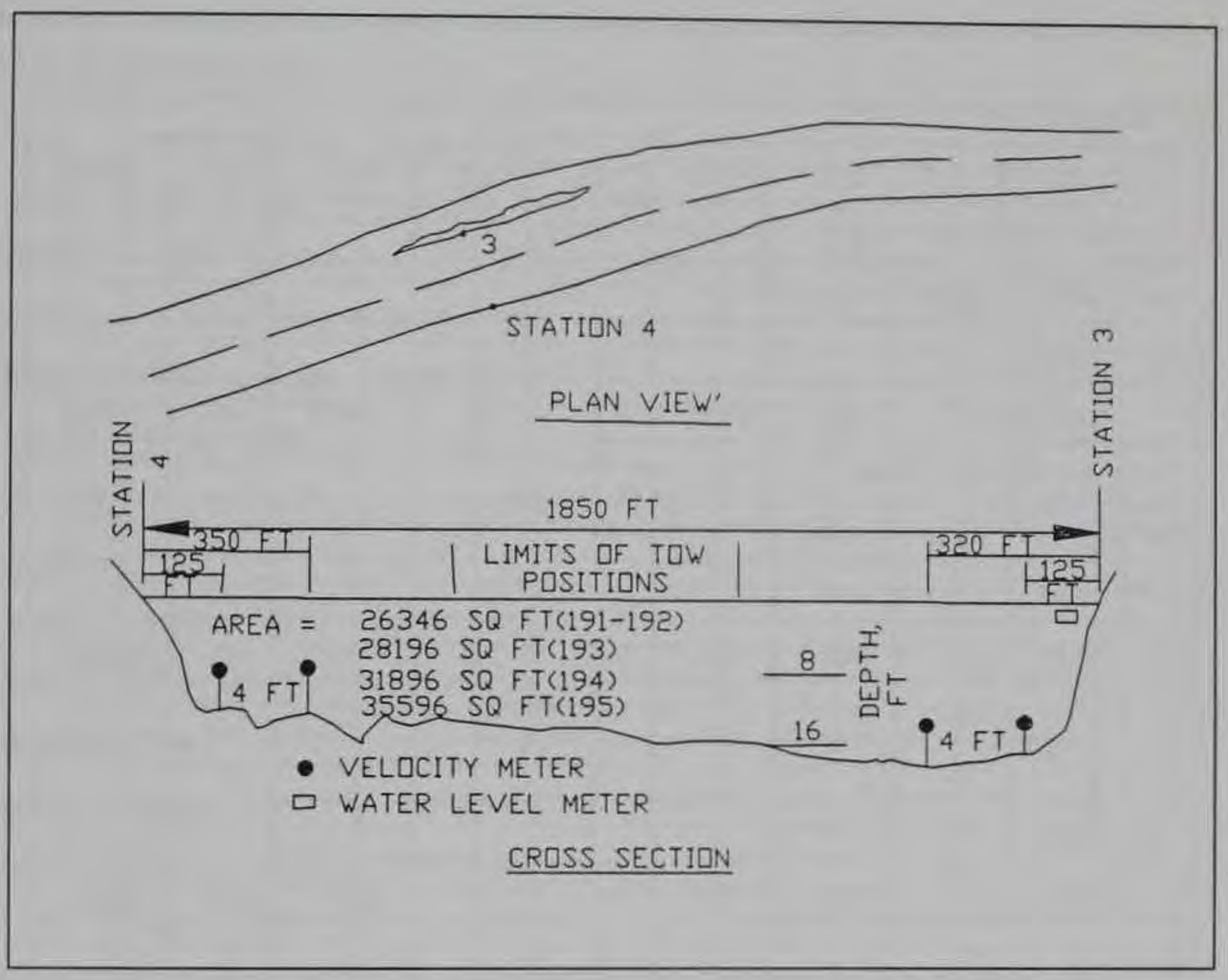

Figure 29. Cross section for ORL tests 90191-90195 (Factor for converting feet to meters is 3.048 and square feet to square meters is 0.0929) 


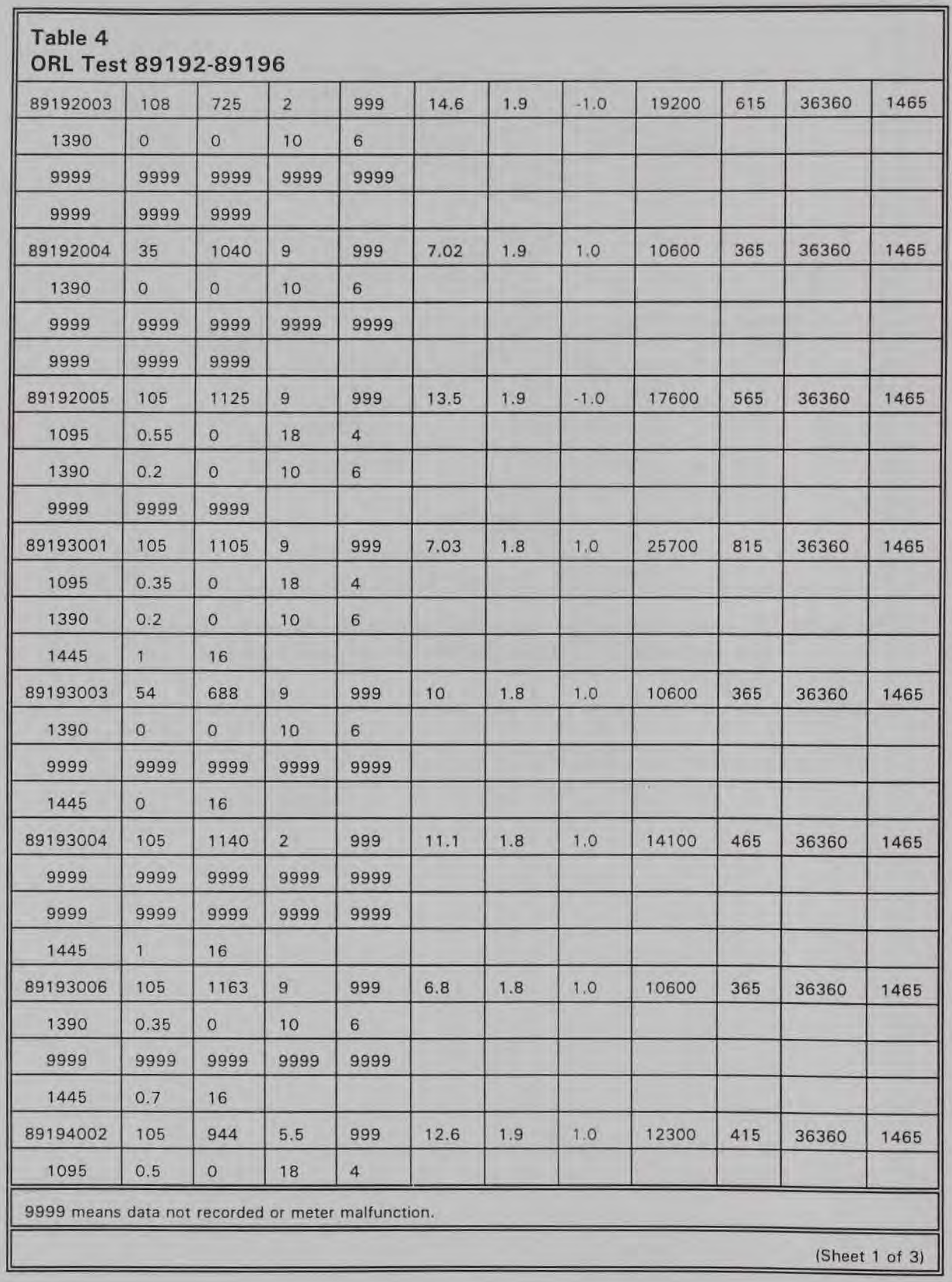




\begin{tabular}{|c|c|c|c|c|c|c|c|c|c|c|c|}
\hline 9999 & 9999 & 9999 & 9999 & 9999 & & & & & & & \\
\hline 1445 & 1.5 & 16 & & & & & & & & & \\
\hline 89194003 & 105 & 1120 & 9 & 999 & 11.9 & 1.9 & -1.0 & 17600 & 565 & 36360 & 1465 \\
\hline 9999 & 9999 & 9999 & 9999 & 9999 & & & & & & & \\
\hline 9999 & 9999 & 9999 & 9999 & 9999 & & & & & & & \\
\hline 1445 & 0.75 & 16 & & & & & & & & & \\
\hline 89194005 & 70 & 365 & 2 & 999 & 5.86 & 1.9 & 1.0 & 14100 & 465 & 36360 & 1465 \\
\hline 1390 & 0 & 0 & 10 & 6 & & & & & & & \\
\hline 9999 & 9999 & 9999 & 9999 & 9999 & & & & & & & \\
\hline 1445 & 0 & 16 & & & & & & & & & \\
\hline 89195001 & 105 & 687 & 9 & 999 & 7.73 & 1.3 & 1.0 & 15400 & 515 & 36360 & 1465 \\
\hline 9999 & 9999 & 9999 & 9999 & 9999 & & & & & & & \\
\hline 9999 & 9999 & 9999 & 9999 & 9999 & & & & & & & \\
\hline 1445 & 0 & 16 & & & & & & & & & \\
\hline 89195002 & 105 & 1170 & 2 & 999 & 10.1 & 1.3 & 1.0 & 8900 & 315 & 36360 & 1465 \\
\hline 9999 & 9999 & 9999 & 9999 & 9999 & & & & & & & \\
\hline 9999 & 9999 & 9999 & 9999 & 9999 & & & & & & & \\
\hline 1445 & 0.5 & 16 & & & & & & & & & \\
\hline 89195003 & 108 & 1181 & 9 & 999 & 12.8 & 1.3 & 1.0 & 14100 & 465 & 36360 & 1465 \\
\hline 9999 & 9999 & 9999 & 9999 & 9999 & & & & & & & \\
\hline 9999 & 9999 & 9999 & 9999 & 9999 & & & & & & & \\
\hline 1445 & 3 & 16 & & & & & & & & & \\
\hline 89195004 & 105 & 731 & 9 & 999 & 8.54 & 1.3 & 1.0 & 15400 & 515 & 36360 & 1465 \\
\hline 9999 & 9999 & 9999 & 9999 & 9999 & & & & & & & \\
\hline 9999 & 9999 & 9999 & 9999 & 9999 & & & & & & & \\
\hline 1445 & 0.7 & 16 & & & & & & & & & \\
\hline 89195005 & 105 & 505 & 2 & 999 & 9.35 & 1.3 & 1.0 & 10600 & 365 & 36360 & 1465 \\
\hline 9999 & 9999 & 9999 & 9999 & 9999 & & & & & & & \\
\hline 9999 & 9999 & 9999 & 9999 & 9999 & & & & & & & \\
\hline 1445 & 0.7 & 16 & & & & & & & & & \\
\hline 89195006 & 175 & 1115 & 10 & 999 & 8.48 & 1.3 & 1.0 & 15400 & 530 & 36360 & 1465 \\
\hline 1095 & 0.7 & 0 & 18 & 4 & & & & & & & \\
\hline
\end{tabular}




\begin{tabular}{|c|c|c|c|c|c|c|c|c|c|c|c|}
\hline 1390 & 0.65 & 0 & 10 & 6 & & & & & & & \\
\hline 1445 & 2.6 & 16 & & & & & & & & & \\
\hline 89195008 & 105 & 1170 & 9 & 999 & 8.8 & 1.3 & 1.0 & 14100 & 465 & 36360 & 1465 \\
\hline 1095 & 0.5 & 0 & 18 & 4 & & & & & & & \\
\hline 1390 & 0.4 & 0 & 10 & 6 & & & & & & & \\
\hline 1445 & 0.75 & 16 & & & & & & & & & \\
\hline 89196001 & 175 & 1120 & 2 & 999 & 10.5 & 1.8 & -1.0 & 29700 & 965 & 36360 & 1465 \\
\hline 1095 & 0.8 & 0 & 18 & 4 & & & & & & & \\
\hline 1390 & 0.55 & 0 & 10 & 6 & & & & & & & \\
\hline 1445 & 2 & 16 & & & & & & & & & \\
\hline 89196002 & 108 & 1082 & 2 & 999 & 16.7 & 1.8 & -1.0 & 19200 & 615 & 36360 & 1465 \\
\hline 9999 & 9999 & 9999 & 9999 & 9999 & & & & & & & \\
\hline 9999 & 9999 & 9999 & 9999 & 9999 & & & & & & & \\
\hline 1445 & 0 & 16 & & & & & & & & & \\
\hline 89196003 & 54 & 720 & 9 & 999 & 13.5 & 1.8 & 1.0 & 25800 & 815 & 36360 & 1465 \\
\hline 1095 & 0.4 & 0 & 18 & 4 & & & & & & & \\
\hline 1390 & 0.3 & 0 & 10 & 6 & & & & & & & \\
\hline 1445 & 2 & 16 & & & & & & & & & \\
\hline 89196006 & 105 & 1115 & 9 & 999 & 12.5 & 1.8 & -1.0 & 15000 & 490 & 36360 & 1465 \\
\hline 1390 & 0.5 & 0 & 10 & 6 & & & & & & & \\
\hline 9999 & 9999 & 9999 & 9999 & 9999 & & & & & & & \\
\hline 1445 & 1.5 & 16 & & & & & & & & & \\
\hline 89196007 & 54 & 1129 & 9 & 999 & 13.9 & 1.8 & 1.0 & 15400 & 515 & 36360 & 1465 \\
\hline 1095 & 0.45 & 0 & 18 & 4 & & & & & & & \\
\hline 1390 & 0.55 & 0 & 10 & 6 & & & & & & & \\
\hline 1445 & 2.25 & 16 & & & & & & & & & \\
\hline \multicolumn{12}{|c|}{$\begin{array}{l}\text { Note: To convert to metric, multiply by these factors: } \\
\text { feet } \times 0.3048 \text { to obtain meters } \\
\text { feet }{ }^{2} \times 0.0929 \text { to obtain square meters } \\
\text { horsepower } \times 9809.5 \text { to obtain watts } \\
\text { inches } \times 0.0254 \text { to obtain meters }\end{array}$} \\
\hline \multicolumn{12}{|c|}{ (Sheet 3 of 3 ) } \\
\hline
\end{tabular}




\begin{tabular}{|c|c|c|c|c|c|c|c|c|c|c|c|}
\hline \multicolumn{12}{|c|}{$\begin{array}{l}\text { Table } 5 \\
\text { ORL Test } 89198-89203\end{array}$} \\
\hline 89198002 & 54 & 1000 & 9 & 999 & 11 & 1.1 & 1,0 & 12200 & 495 & 20460 & 1020 \\
\hline 76 & 0.25 & 0 & 13 & 8 & & & & & & & \\
\hline 20 & 1.5 & 4 & & & & & & & & & \\
\hline 89198003 & 105 & 1139 & 9 & 999 & 12.5 & 1.1 & -1.0 & 13500 & 545 & 20460 & 1020 \\
\hline 76 & 0.65 & 0 & 13 & 8 & & & & & & & \\
\hline 20 & 4.5 & 4 & & & & & & & & & \\
\hline 89198004 & 175 & 1113 & 2 & 999 & 11.4 & 1.1 & -1.0 & 12900 & 520 & 20460 & 1020 \\
\hline 76 & 0.3 & 0 & 13 & 8 & & & & & & & \\
\hline 20 & 2 & 4 & & & & & & & & & \\
\hline 89198005 & 194 & 1115 & 9 & 999 & 7.25 & 1.1 & -1.0 & 12900 & 520 & 20460 & 1020 \\
\hline 76 & 0.5 & 0 & 13 & 8 & & & & & & & \\
\hline 20 & 1.5 & 4 & & & & & & & & & \\
\hline 89199001 & 105 & 1125 & 9 & 999 & 12.9 & 0.9 & -1.0 & 13600 & 365 & 20460 & 1020 \\
\hline 76 & 0.6 & 0 & 13 & 8 & & & & & & & \\
\hline 20 & 5 & 4 & & & & & & & & & \\
\hline 89199002 & 35 & 269 & 2 & 999 & 15.5 & 0.9 & -1.0 & 11300 & 470 & 20460 & 1020 \\
\hline 9999 & 9999 & 9999 & 9999 & 9999 & & & & & & & \\
\hline 20 & 0 & 4 & & & & & & & & & \\
\hline 89199003 & 245 & 1120 & 9 & 999 & 7.52 & 0.9 & 1.0 & 10300 & 430 & 20460 & 1020 \\
\hline 76 & 1.05 & 0 & 13 & 8 & & & & & & & \\
\hline 20 & 4 & 4 & & & & & & & & & \\
\hline 89199004 & 105 & 1065 & 8 & 999 & 9.05 & 0.9 & -1.0 & 11700 & 480 & 20460 & 1020 \\
\hline 76 & 0.4 & 0 & 13 & 8 & & & & & & & \\
\hline 20 & 1.5 & 4 & & & & & & & & & \\
\hline 89200002 & 70 & 702 & 9 & 999 & 9.5 & 1 & -1.0 & 15800 & 650 & 20460 & 1020 \\
\hline 76 & 0.2 & 0 & 13 & 8 & & & & & & & \\
\hline 20 & 1.5 & 4 & & & & & & & & & \\
\hline 89200003 & 105 & 1155 & 9 & 999 & 12.2 & 1 & 1.0 & 14100 & 570 & 20460 & 1020 \\
\hline 76 & 0.55 & 0 & 13 & 8 & & & & & & & \\
\hline 20 & 2.25 & 4 & & & & & & & & & \\
\hline 89201001 & 105 & 1139 & 2 & 999 & 11 & 1.8 & 1.8 & 14500 & 595 & 20460 & 1020 \\
\hline
\end{tabular}

Chapter 6 Comparison of 1995 Analytical Method with Independent Field Data 


\begin{tabular}{|c|c|c|c|c|c|c|c|c|c|c|c|}
\hline \multicolumn{12}{|c|}{ Table 5 (Continued) } \\
\hline 9999 & 9999 & 9999 & 9999 & 9999 & & & & & & & \\
\hline 20 & 1.5 & 4 & & & & & & & & & \\
\hline 89201002 & 105 & 1170 & 9 & 999 & 13.6 & 1.8 & -1.0 & 14100 & 570 & 20460 & 1020 \\
\hline 76 & 0.45 & 0 & 13 & 8 & & & & & & & \\
\hline 20 & 5 & 4 & & & & & & & & & \\
\hline 89201003 & 105 & 1065 & 9 & 999 & 9.9 & 1.8 & -1.0 & 6000 & 270 & 20460 & 1020 \\
\hline 76 & 0.65 & 0 & 13 & 8 & & & & & & & \\
\hline 20 & 1.5 & 4 & & & & & & & & & \\
\hline 89201004 & 52 & 898 & 9 & 999 & 9.03 & 1.8 & 1.0 & 11300 & 470 & 20460 & 1020 \\
\hline 76 & 0.3 & 0 & 13 & 9 & & & & & & & \\
\hline 20 & 0.75 & 4 & - & & & & & & & & \\
\hline 89201005 & 105 & 882 & 2 & 999 & 13.1 & 1.8 & -1.0 & 9800 & 410 & 20460 & 1020 \\
\hline 76 & 0 & 0 & 13 & 8 & & & & & & & \\
\hline 20 & 1 & 4 & & & & & & & & & \\
\hline 89202001 & 105 & 702 & 9 & 999 & 10.6 & 1.8 & -1.0 & 10700 & 445 & 20460 & 1020 \\
\hline 9999 & 9999 & 9999 & 9999 & 9999 & & & & & & & \\
\hline 20 & 1.5 & 4 & & & & & & & & & \\
\hline 89202003 & 210 & 1167 & 9 & 999 & 10.4 & 1.8 & -1.0 & 14200 & 575 & 20460 & 1020 \\
\hline 9999 & 9999 & 9999 & 9999 & 9999 & & & & & & & \\
\hline 20 & 7 & 4 & & & & & & & & & \\
\hline 89202004 & 175 & 1129 & 2 & 999 & 7.94 & 1.8 & $-1,0$ & 15600 & 640 & 20460 & 1020 \\
\hline 9999 & 9999 & 9999 & 9999 & 9999 & & & & & & & \\
\hline 20 & 1 & 4 & & & & & & & & & \\
\hline 89202005 & 105 & 1115 & 9 & 999 & 11.5 & 1.8 & -1.0 & 14600 & 595 & 20460 & 1020 \\
\hline 9999 & 9999 & 9999 & 9999 & 9999 & & & & & & & \\
\hline 20 & 3 & 4 & & & & & & & & & \\
\hline 89202006 & 104 & 395 & 2 & 999 & 15.2 & 1.8 & -1.0 & 12900 & 520 & 20460 & 1020 \\
\hline 9999 & 9999 & 9999 & 9999 & 9999 & & & & & & & \\
\hline 20 & 0.5 & 4 & & & & & & & & & \\
\hline 89202007 & 41 & 96 & 5 & 999 & 12.5 & 1.8 & -1.0 & 16600 & 690 & 20460 & 1020 \\
\hline 9999 & 9999 & 9999 & 9999 & 9999 & & & & & & & \\
\hline 20 & 0 & 4 & & & & & & & & & \\
\hline & & & & & & & & & & (She & 2 of 3$)$ \\
\hline
\end{tabular}




\begin{tabular}{|c|c|c|c|c|c|c|c|c|c|c|c|}
\hline 89202008 & 105 & 892 & 9 & 999 & 5.21 & 1.8 & 1.0 & 12900 & 520 & 20460 & 1020 \\
\hline 9999 & 9999 & 9999 & 9999 & 9999 & & & & & & & \\
\hline 20 & 1 & 4 & & & & & & & & & \\
\hline 89203001 & 34 & 148 & 9 & 999 & 12.8 & 1.8 & 1.0 & 13100 & 530 & 20460 & 1020 \\
\hline 9999 & 9999 & 9999 & 9999 & 9999 & & & & & & & \\
\hline 20 & 0 & 4 & & & & & & & & & \\
\hline 89203002 & 105 & 1142 & 9 & 999 & 10.2 & 1.8 & -1.0 & 11700 & 480 & 20460 & 1020 \\
\hline 9999 & 9999 & 9999 & 9999 & 9999 & & & & & & & \\
\hline 20 & 2 & 4 & & & & & & & & & \\
\hline 89203003 & 70 & 892 & 9 & 999 & 9.1 & 1.8 & 1.0 & 13400 & 540 & 20460 & 1020 \\
\hline 9999 & 9999 & 9999 & 9999 & 9999 & & & & & & & \\
\hline 20 & 1.5 & 4 & & & & & & & & & \\
\hline 89203004 & 105 & 1070 & 9 & 999 & 7.04 & 1.8 & 1.0 & 12700 & 480 & 20460 & 1020 \\
\hline 9999 & 9999 & 9999 & 9999 & 9999 & & & & & & & \\
\hline 20 & 1.5 & 4 & & & & & & & & & \\
\hline 89203005 & 105 & 1113 & 9 & 999 & 9.8 & 1.8 & -1.0 & 10200 & 420 & 20460 & 1020 \\
\hline 9999 & 9999 & 9999 & 9999 & 9999 & & & & & & & \\
\hline 20 & 1 & 4 & & & & & & & & & \\
\hline \multicolumn{12}{|c|}{$\begin{array}{l}\text { Note: To convert to metric, multiply by these factors: } \\
\text { feet } \times 0.3048 \text { to obtain meters } \\
\text { feet }{ }^{2} \times 0.0929 \text { to obtain square meters } \\
\text { horsepower } \times 9809.5 \text { to obtain watts } \\
\text { inches } \times 0.0254 \text { to obtain meters }\end{array}$} \\
\hline
\end{tabular}




\begin{tabular}{|c|c|c|c|c|c|c|c|c|c|c|c|}
\hline \multicolumn{12}{|c|}{$\begin{array}{l}\text { Table } 6 \\
\text { ORL Test } 90172-90179\end{array}$} \\
\hline 90172004 & 105 & 687 & 9 & 999 & 7.61 & 0.9 & 1.0 & 7500 & 350 & 28626 & 1100 \\
\hline 130 & 0.25 & 0 & 23 & 6 & & & & & & & \\
\hline 960 & 0.15 & 0 & 25 & 6 & & & & & & & \\
\hline 9999 & 9999 & 9999 & & & & & & & & & \\
\hline 90172006 & 105 & 705 & 9 & 999 & 9.13 & 0.9 & 1.0 & 4200 & 225 & 28626 & 1100 \\
\hline 960 & 0.25 & 0 & 25 & 6 & & & & & & & \\
\hline 9999 & 9999 & 9999 & 9999 & 9999 & & & & & & & \\
\hline 9999 & 9999 & 9999 & & & & & & & & & \\
\hline 90172009 & 108 & 870 & 9 & 999 & 12.3 & 0.9 & 1.0 & 1000 & 100 & 28626 & 1100 \\
\hline 130 & 0.75 & 0 & 23 & 6 & & & & & & & \\
\hline 960 & 0.4 & 0 & 25 & 6 & & & & & & & \\
\hline 20 & 5 & 4 & & & & & & & & & \\
\hline 90173002 & 105 & 1113 & 2 & 999 & 8.55 & 0.7 & 1.0 & 7500 & 350 & 28626 & 1100 \\
\hline 130 & 0.15 & 0 & 23 & 6 & & & & & & & \\
\hline 960 & 0.1 & 0 & 25 & 6 & & & & & & & \\
\hline 20 & 0.5 & 4 & & & & & & & & & \\
\hline 90174003 & 105 & 1113 & 9 & 999 & 11.7 & 0.9 & 1.0 & 7500 & 350 & 28626 & 1100 \\
\hline 130 & 0.7 & 0 & 23 & 6 & & & & & & & \\
\hline 960 & 0.4 & 0 & 25 & 6 & & & & & & & \\
\hline 20 & 4.5 & 4 & & & & & & & & & \\
\hline 90174004 & 105 & 1139 & 9 & 999 & 12.1 & 0.9 & -1.0 & 6700 & 325 & 28626 & 1100 \\
\hline 130 & 0.4 & 0 & 23 & 6 & & & & & & & \\
\hline 960 & 0.35 & 0 & 25 & 6 & & & & & & & \\
\hline 20 & 3.5 & 4 & & & & & & & & & \\
\hline 90174005 & 105 & 1080 & 9 & 999 & 9.97 & 0.9 & -1.0 & 8900 & 400 & 28626 & 1100 \\
\hline 130 & 0.4 & 0 & 23 & 6 & & & & & & & \\
\hline 960 & 0.4 & 0 & 25 & 6 & & & & & & & \\
\hline 20 & 2 & 4 & & & & & & & & & \\
\hline 90175002 & 105 & 1115 & 9 & 999 & 7.9 & 1 & 1.0 & 8900 & 400 & 28626 & 1100 \\
\hline 130 & 0.25 & 0 & 23 & 6 & & & & & & & \\
\hline \multicolumn{12}{|c|}{9999 means data not recorded or meter malfunction. } \\
\hline \multicolumn{12}{|c|}{ (Continued) } \\
\hline
\end{tabular}




\begin{tabular}{|c|c|c|c|c|c|c|c|c|c|c|c|}
\hline 960 & 0.2 & 0 & 23 & 6 & & & & & & & \\
\hline 20 & 2 & 4 & & & & & & & & & \\
\hline 90176001 & 105 & 1125 & 9 & 999 & 9.92 & 0.7 & 1.0 & 7500 & 350 & 28626 & 1100 \\
\hline 130 & 0.4 & 0 & 23 & 6 & & & & & & & \\
\hline 960 & 0.3 & 0 & 25 & 6 & & & & & & & \\
\hline 20 & 1.5 & 4 & & & & & & & & & \\
\hline 90176002 & 105 & 1105 & 9 & 999 & 11.2 & 0.7 & -1.0 & 8800 & 400 & 28626 & 1100 \\
\hline 130 & 0.4 & 0 & 23 & 6 & & & & & & & \\
\hline 960 & 0.3 & 0 & 25 & 6 & & & & & & & \\
\hline 20 & 1.5 & 4 & & & & & & & & & \\
\hline 90176003 & 35 & 687 & 9 & 999 & 10.8 & 0.7 & 1.0 & 4800 & 250 & 28626 & 1100 \\
\hline 130 & 0.15 & 0 & 23 & 6 & & & & & & & \\
\hline 960 & 0 & 0 & 25 & 6 & & & & & & & \\
\hline 20 & 2 & 4 & & & & & & & & & \\
\hline 90177002 & 105 & 1115 & 9 & 999 & 11.5 & 0.7 & -1.0 & 11600 & 500 & 28626 & 1100 \\
\hline 130 & 0.35 & 0 & 23 & 6 & & & & & & & \\
\hline 960 & 0.25 & 0 & 25 & 6 & & & & & & & \\
\hline 20 & 2.5 & 4 & & & & & & & & & \\
\hline 90179005 & 108 & 1085 & 9 & 999 & 12.1 & 0.6 & -1.0 & 6800 & 330 & 28626 & 1100 \\
\hline 960 & 0.3 & 0 & 25 & 6 & & & & & & & \\
\hline 130 & 0.4 & 0 & 23 & 6 & & & & & & & \\
\hline 20 & 3 & 4 & & & & & & & & & \\
\hline 90179006 & 70 & 738 & 9 & 999 & 18.5 & 0.6 & 1.0 & 7500 & 350 & 28626 & 1100 \\
\hline 130 & 0.4 & 0 & 23 & 6 & & & & & & & \\
\hline 960 & 0.15 & 0 & 25 & 6 & & & & & & & \\
\hline 20 & 3 & 4 & & & & & & & & & \\
\hline \multicolumn{12}{|c|}{$\begin{array}{l}\text { Note: To convert to metric, multiply by these factors: } \\
\text { feet } \times 0.3048 \text { to obtain meters } \\
\text { feet }{ }^{2} \times 0.0929 \text { to obtain square meters } \\
\text { horsepower } \times 9809.5 \text { to obtain watts } \\
\text { inches } \times 0.0254 \text { to obtain meters }\end{array}$} \\
\hline
\end{tabular}




\begin{tabular}{|c|c|c|c|c|c|c|c|c|c|c|c|}
\hline \multicolumn{12}{|c|}{$\begin{array}{l}\text { Table } 7 \\
\text { ORL Test 90191-90195 }\end{array}$} \\
\hline 90191002 & 105 & 1170 & 2 & 999 & 9.24 & 0.6 & 1.0 & 13500 & 1050 & 26346 & 1850 \\
\hline 9999 & 9999 & 9999 & 9999 & 9999 & & & & & & & \\
\hline 9999 & 9999 & 9999 & 9999 & 9999 & & & & & & & \\
\hline 1530 & 0.2 & 0 & 18 & 4 & & & & & & & \\
\hline 1725 & 0.1 & 0 & 17 & 4 & & & & & & & \\
\hline 9999 & 9999 & 9999 & & & & & & & & & \\
\hline 90191003 & 35 & 328 & 2 & 999 & 13.7 & 0.6 & -1.0 & 13500 & 1050 & 26346 & 1850 \\
\hline 350 & 0.05 & 0 & 13 & 4 & & & & & & & \\
\hline 125 & 0.15 & 0 & 12 & 4 & & & & & & & \\
\hline 1530 & 0.2 & 0 & 18 & 4 & & & & & & & \\
\hline 1725 & 0 & 0 & 17 & 4 & & & & & & & \\
\hline 9999 & 9999 & 9999 & & & & & & & & & \\
\hline 90191005 & 108 & 739 & 2 & 999 & 22.5 & 0.6 & -1.0 & 15200 & 1150 & 26346 & 1850 \\
\hline 350 & 0.15 & 0 & 13 & 4 & & & & & & & \\
\hline 125 & 0.1 & 0 & 12 & 4 & & & & & & & \\
\hline 1530 & 0.35 & 0 & 18 & 4 & & & & & & & \\
\hline 1725 & 0.15 & 0 & 17 & 4 & & & & & & & \\
\hline 9999 & 9999 & 9999 & & & & & & & & & \\
\hline 90191006 & 50 & 1185 & 9 & 999 & 9.72 & 0.6 & 1.0 & 10600 & 850 & 26346 & 1850 \\
\hline 350 & 0.15 & 0 & 13 & 4 & & & & & & & \\
\hline 125 & 0.1 & 0 & 12 & 4 & & & & & & & \\
\hline 1530 & 0.15 & 0 & 18 & 4 & & & & & & & \\
\hline 1725 & 0.1 & 0 & 17 & 4 & & & & & & & \\
\hline 9999 & 9999 & 9999 & & & & & & & & & \\
\hline 90192001 & 105 & 1143 & 9 & 999 & 9.51 & 1.1 & -1.0 & 12400 & 975 & 26346 & 1850 \\
\hline 9999 & 9999 & 9999 & 9999 & 9999 & & & & & & & \\
\hline 9999 & 9999 & 9999 & 9999 & 9999 & & & & & & & \\
\hline 1530 & 0 & 0 & 18 & 4 & & & & & & & \\
\hline 1725 & 0 & 0 & 17 & 4 & & & & & & & \\
\hline 1830 & 0 & 10 & & & & & & & & & \\
\hline mea & a $n$ & acdo & mote & alfun & & & & & & & \\
\hline & & & & & & & & & & IShe & of 41 \\
\hline
\end{tabular}




\begin{tabular}{|c|c|c|c|c|c|c|c|c|c|c|c|}
\hline 90192003 & 105 & 1139 & 2 & 999 & 8.9 & 1.1 & 1.0 & 14400 & 1100 & 26346 & 1850 \\
\hline 350 & 0.2 & 0 & 13 & 4 & & & & & & & \\
\hline 125 & 0.3 & 0 & 12 & 4 & & & & & & & \\
\hline 1530 & 0.45 & 0 & 18 & 4 & & & & & & & \\
\hline 1725 & 0.3 & 0 & 17 & 4 & & & & & & & \\
\hline 1830 & 2.5 & 10 & & & & & & & & & \\
\hline 90192004 & 105 & 750 & 9 & 999 & 13.2 & 1.1 & -1.0 & 14400 & 1100 & 26346 & 1850 \\
\hline 350 & 0.1 & 0 & 13 & 4 & & & & & & & \\
\hline 125 & 0.25 & 0 & 12 & 4 & & & & & & & \\
\hline 1530 & 0.75 & 0 & 18 & 4 & & & & & & & \\
\hline 1725 & 0.4 & 0 & 17 & 4 & & & & & & & \\
\hline 1830 & 3.25 & 10 & & & & & & & & & \\
\hline 90193001 & 50 & 914 & 9 & 999 & 10.4 & 1.1 & 1.0 & 13375 & 975 & 28196 & 1850 \\
\hline 9999 & 9999 & 9999 & 9999 & 9999 & & & & & & & \\
\hline 9999 & 9999 & 9999 & 9999 & 9999 & & & & & & & \\
\hline 9999 & 9999 & 9999 & 9999 & 9999 & & & & & & & \\
\hline 350 & 0.15 & 0 & 13 & 4 & & & & & & & \\
\hline 1830 & 1.5 & 10 & & & & & & & & & \\
\hline 90193002 & 106 & 700 & 2 & 999 & 13.1 & 1.1 & -1.0 & 13800 & 1000 & 28196 & 1850 \\
\hline 9999 & 9999 & 9999 & 9999 & 9999 & & & & & & & \\
\hline 9999 & 9999 & 9999 & 9999 & 9999 & & & & & & & \\
\hline 350 & 0 & 0 & 13 & 4 & & & & & & & \\
\hline 125 & 0 & 0 & 12 & 4 & & & & & & & \\
\hline 1830 & 0.75 & 10 & & & & & & & & & \\
\hline 90193003 & 105 & 1135 & 9 & 999 & 7.03 & 1.1 & 1.0 & 13800 & 1000 & 28196 & 1850 \\
\hline 9999 & 9999 & 9999 & 9999 & 9999 & & & & & & & \\
\hline 350 & 0.15 & 0 & 13 & 4 & & & & & & & \\
\hline 125 & 0.2 & 0 & 12 & 4 & & & & & & & \\
\hline 1530 & 0.4 & 0 & 18 & 4 & & & & & & & \\
\hline 1830 & 1.5 & 10 & & & & & & & & & \\
\hline 90193004 & 108 & 439 & 2 & 999 & 17.2 & 1,1 & -1.0 & 14650 & 1050 & 28196 & 1850 \\
\hline 9999 & 9999 & 9999 & 9999 & 9999 & & & & & & & \\
\hline
\end{tabular}




\begin{tabular}{|c|c|c|c|c|c|c|c|c|c|c|c|}
\hline 9999 & 9999 & 9999 & 9999 & 9999 & & & & & & & \\
\hline 9999 & 9999 & 9999 & 9999 & 9999 & & & & & & & \\
\hline 9999 & 9999 & 9999 & 9999 & 9999 & & & & & & & \\
\hline 1830 & 0.5 & 0 & & & & & & & & & \\
\hline 90193005 & 108 & 710 & 2 & 999 & 14.8 & 1.1 & -1.0 & 15825 & 1125 & 28196 & 1850 \\
\hline 9999 & 9999 & 9999 & 9999 & 9999 & & & & & & & \\
\hline 9999 & 9999 & 9999 & 9999 & 9999 & & & & & & & \\
\hline 350 & 0 & 0 & 13 & 4 & & & & & & & \\
\hline 125 & 0 & 0 & 12 & 4 & & & & & & & \\
\hline 1830 & 1 & 10 & & & & & & & & & \\
\hline 90194001 & 105 & 918 & 9 & 999 & 10.4 & 1.6 & 1.0 & 15800 & 1000 & 31896 & 1850 \\
\hline 9999 & 9999 & 9999 & 9999 & 9999 & & & & & & & \\
\hline 350 & 0.9 & 0 & 13 & 4 & & & & & & & \\
\hline 125 & 0.35 & 0 & 12 & 4 & & & & & & & \\
\hline 1530 & 0.5 & 0 & 18 & 4 & & & & & & & \\
\hline 1830 & 3 & 10 & & & & & & & & & \\
\hline 90194004 & 50 & 720 & 9 & 999 & 9.09 & 1.6 & 1.0 & 12400 & 800 & 31896 & 1850 \\
\hline 9999 & 9999 & 9999 & 9999 & 9999 & & & & & & & \\
\hline 9999 & 9999 & 9999 & 9999 & 9999 & & & & & & & \\
\hline 9999 & 9999 & 9999 & 9999 & 9999 & & & & & & & \\
\hline 9999 & 9999 & 9999 & 9999 & 9999 & & & & & & & \\
\hline 1830 & 0 & 10 & & & & & & & & & \\
\hline 90195001 & 105 & 1143 & 9 & 999 & 8.95 & 2.6 & 1.0 & 14850 & 850 & 35596 & 1850 \\
\hline 9999 & 9999 & 9999 & 9999 & 9999 & & & & & & & \\
\hline 9999 & 9999 & 9999 & 9999 & 9999 & & & & & & & \\
\hline 9999 & 9999 & 9999 & 9999 & 9999 & & & & & & & \\
\hline 1530 & 0.5 & 0 & 18 & 4 & & & & & & & \\
\hline 1830 & 1.5 & 10 & & & & & & & & & \\
\hline 90195002 & 105 & 1141 & 9 & 999 & 8.51 & 2.6 & 1.0 & 19900 & 1100 & 35596 & 1850 \\
\hline 9999 & 9999 & 9999 & 9999 & 9999 & & & & & & & \\
\hline 9999 & 9999 & 9999 & 9999 & 9999 & & & & & & & \\
\hline & & & & & & & & & & \multicolumn{2}{|c|}{ (Sheet 3 of 4 ) } \\
\hline
\end{tabular}




\begin{tabular}{|c|c|c|c|c|c|c|c|c|c|c|c|}
\hline 125 & 0.45 & 0 & 12 & 4 & & & & & & & \\
\hline 1530 & 0.55 & 0 & 18 & 4 & & & & & & & \\
\hline 1830 & 2 & 10 & & & & & & & & & \\
\hline 90195003 & 140 & 1143 & 2 & 999 & 16.5 & 2.6 & -1.0 & 22950 & 1250 & 35596 & 1850 \\
\hline 9999 & 9999 & 9999 & 9999 & 9999 & & & & & & & \\
\hline 9999 & 9999 & 9999 & 9999 & 9999 & & & & & & & \\
\hline 9999 & 9999 & 9999 & 9999 & 9999 & & & & & & & \\
\hline 9999 & 9999 & 9999 & 9999 & 9999 & & & & & & & \\
\hline 1830 & 2 & 10 & & & & & & & & & \\
\hline 90195004 & 105 & 1175 & 2 & 999 & 9.19 & 2.6 & 1.0 & 12100 & 700 & 35596 & 1850 \\
\hline 9999 & 9999 & 9999 & 9999 & 9999 & & & & & & & \\
\hline 9999 & 9999 & 9999 & 9999 & 9999 & & & & & & & \\
\hline 125 & 0 & 0 & 12 & 4 & & & & & & & \\
\hline 1530 & 0 & 0 & 18 & 4 & & & & & & & \\
\hline 1830 & 0 & 10 & & & & & & & & & \\
\hline $\begin{array}{l}\text { Note: To cc } \\
\text { feet } \\
\text { feet }{ }^{2} \\
\text { horse } \\
\text { inche } \\
\text { Description } \\
\text { First line: } \\
\text { 1. Test nan } \\
\text { 2. Vessel b } \\
\text { 3. Length o } \\
\text { 4. Draft of } \\
\text { 5. Towboat } \\
\text { 6. Vessel s } \\
\text { 7. Ambient } \\
\text { 8. Upbounc } \\
\text { 9. Channel } \\
\text { 10. Distanct } \\
\text { 11. Total ch } \\
\text { 12. Total w } \\
\text { Next 1,2, or } \\
\text { 1. Distance } \\
\text { 2. Maximur } \\
\text { 3. Ambient } \\
\text { 4. Local de } \\
\text { 5. Distance } \\
\text { Next } 1 \text { line: } \\
\text { 1. Distance } \\
\text { 2. Water-le } \\
\text { 3. Local de }\end{array}$ & $\begin{array}{l}\text { Ivert to } \\
0.3048 \\
0.092 \\
\text { ower } x \\
\times 0.02 \\
\text { f items } \\
\\
\text { am, feet } \\
\text { barges, } \\
\text { arges, } f \\
\text { power, } \\
\text { eed rela } \\
\text { elocity } \\
=1.0, \\
\text { rea left } \\
\text { from lef } \\
\text { nnel are } \\
\text { ter surfa } \\
4 \text { lines: } \\
\text { rom left } \\
\text { lupbou } \\
\text { elocity } \\
\text { th at me } \\
\text { rom me } \\
\text { from lef } \\
\text { el draw } \\
\text { th at wa }\end{array}$ & $\begin{array}{l}\text { letric, m } \\
\text { o obtain } \\
\text { to obtai } \\
809.5 \mathrm{t} \\
4 \text { to obt } \\
\text { databas } \\
\text { eet } \\
\text { rsepow } \\
\text { Discha } \\
\text { Divnbou } \\
\text { tow ce } \\
\text { bank to } \\
\text { feet }{ }^{2} \\
\text { width. } \\
\text { bank to } \\
\text { or mir } \\
\text { this me } \\
\text { er, feet } \\
\text { er to bot ing } \\
\text { bank to }\end{array}$ & $\begin{array}{l}\text { und, feet } \\
\text { ge/total } \\
d=-1 . \\
\text { ter line, } \\
\text { tow cent } \\
\text { feet } \\
\text { elocity n } \\
\text { imum (do } \\
\text { ter, feet/ } \\
\text { om, feet } \\
\text { vave gat } \\
\text { les } \\
\text { feet }\end{array}$ & $\begin{array}{l}\text { these fa } \\
\text { heters } \\
\text { latts } \\
\text { second } \\
\text { hannel } \\
\text { feet } \\
\text { rine, } \\
\text { f } \\
\text { wnboun } \\
\text { econd } \\
\text { ter, fee }\end{array}$ & velocit & cond & tow, te & second & & & \\
\hline
\end{tabular}




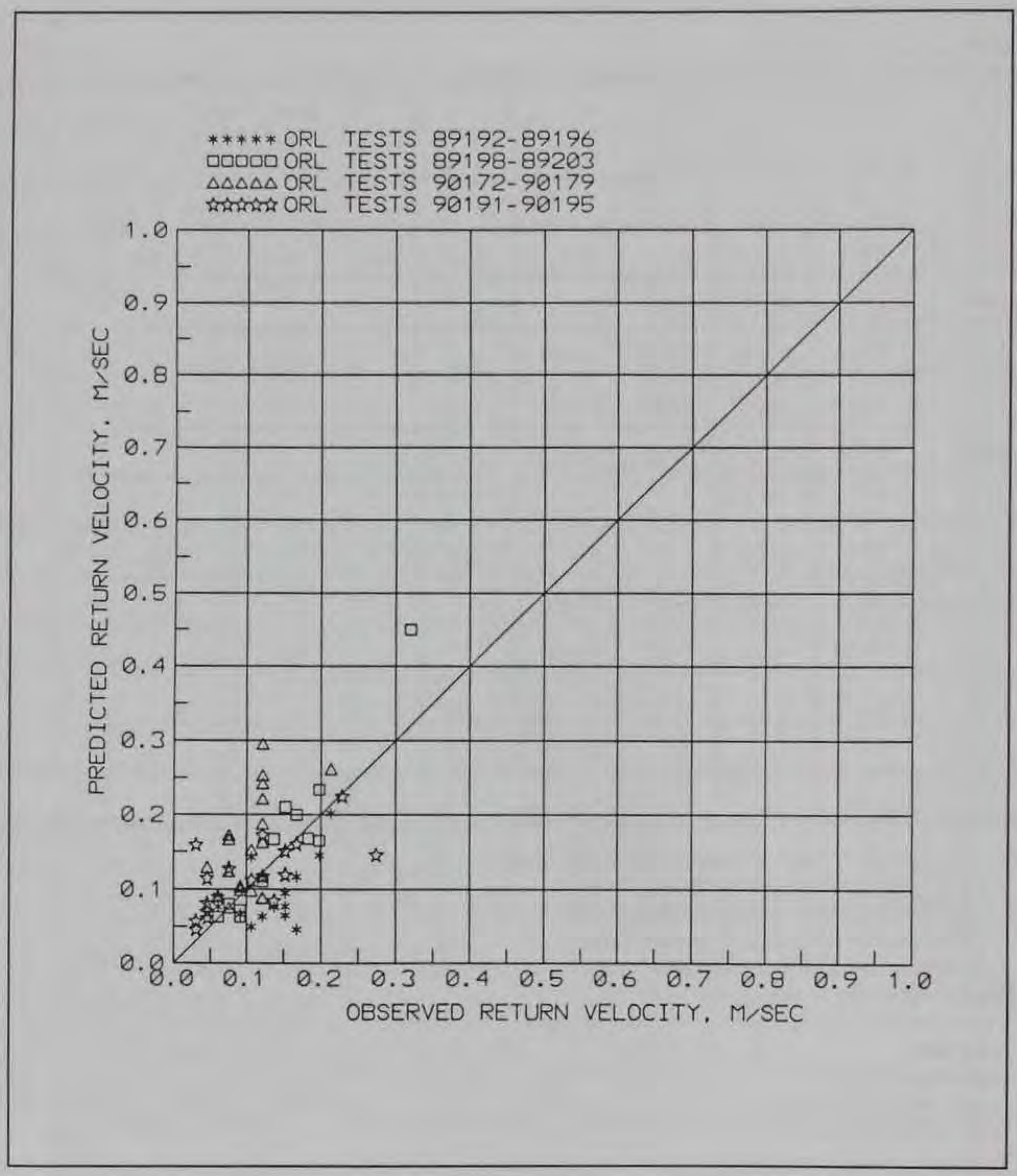

Figure 30. Observed ORL prototype return velocity versus computed return velocity using 1995 analytical method 


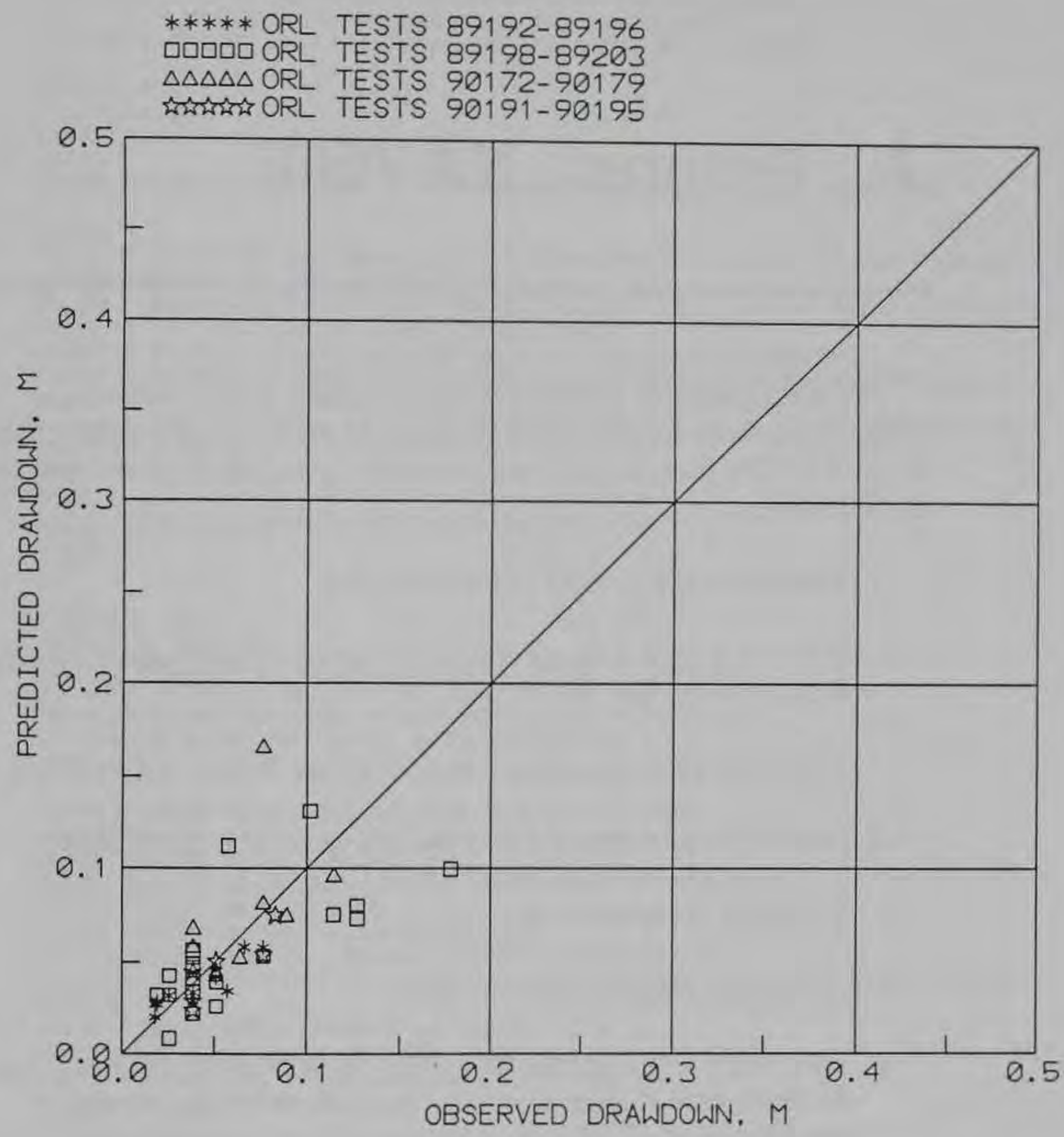

Figure 31. Observed ORL prototype drawdown versus computed drawdown using 1995 analytical method 


\section{Program NAVEFF}

The 1995 analytical method for return velocity and drawdown was programmed in QuickBASIC 4.5 language as shown in the program listing in Figure 32. The program prompts for metric or english units and then requests the following:

a. Total channel top width in meters or feet.

b. Distance from tow center line to left bank in meters or feet (when facing downsteam).

c. Total channel cross-sectional area in square meters or square feet.

d. Channel cross-sectional area from tow center line to left bank.

$e$. Tow draft in meters or feet.

f. Total barge width in meters or feet.

g. Total barge length in meters or feet. In determining the displacement thickness used to determine effective draft and beam, a single temperature of $17{ }^{\circ} \mathrm{C}$ is used because of lack of sensitivity to temperature.

h. Average channel velocity in meters/sec or $\mathrm{ft} / \mathrm{sec}$. The program applies a factor of 1.2 to the average channel velocity to determine the vessel speed relative to the water.

$i$. Vessel speed relative to ground in meters/second or feet/second.

j. Direction of travel $\mathrm{U}$ or $\mathrm{u}$ for upbound, $\mathrm{D}$ or $\mathrm{d}$ for downbound.

The program then outputs $V_{r}(Y)$ in $\mathrm{m} / \mathrm{sec}$ or $\mathrm{ft} / \mathrm{sec}$ and $\mathrm{z}(\mathrm{Y})$ in meters or feet at five points on each side of the tow. The five points are equally spaced and begin at one tow width away from the vessel center line and end at the shoreline. The program then prompts for a new vessel speed using the same channel and tow geometry. The program will indicate if the speed entered 
'PROGRAM NAVEFF.BAS-BASED ON SCHIJF FOR ENTIRE CHANNEL

IAND 1995 WES REPT ON RETURN VELOCITY AND DRAWDOWN

REM THIS PRINTS OUT ALL DATA AND GIVES A VISUAL PICTURE

CLS

SCREEN 9

COLOR 11,4

LINE $(700,600)-(0,0), 4, B E$

PRINT

PRINT TAB(12); "PROGRAM NAVEFF.BAS-SCHIJF METHOD PLUS EMPIRICISM"

$\mathrm{PC}=0$

PRINT

PRINT " EXPERIMENTAL DATA USED IN DEVELOPMENT LIMITED TO THE FOLLOWING:"

PRINT " BLOCKAGE RATIO LESS THAN 85"

PRINT " DISTANCE ON SIDE OF VESSEL GREATER THAN $10 \%$ OF TOTAL CHANNEL WIDTH"

PRINT " AND GREATER THAN VESSEL BEAM"

PRINT " VESSEL LENGTH GREATER THAN 40\% OF CHANNEL WIDTH"

PRINT " RETURN VELOCITY AND DRAWDOWN LIMITED TO ONE BEAM WIDTH AWAY"

PRINT " FROM VESSEL CENTERLINE OUT TO THE SHORELINE"

PRINT " VESSEL SPEED RELATIVE TO WATER SHOULD BE $0.35-0.9 *$ LIMIT SPEED"

FOR $I=1$ TO 10

PRINT

NEXT I

PRINT TAB (25); "Press SPACE BAR to continue"

SLEEP

CLS

C

PLAG1\$ = "N"

FLAG2\$ = "N"

5 INPUT "ENGLISH OR METRIC UNITS (E OR M) ", unIS

IF uni $\$=" E "$ OR uni $=$ "e" THEN FLAG1\$ = "Y"

IF uni\$ = "M" OR uni $=$ "m" THEN FLAG2\$ = "Y"

IF FLAG1\$ = "Y" OR FLAG2\$ = "X" THEN GOTO 7

GOTO 5

7

INPUT "ENTER TOTAL CHANNEL TOP WIDTH ", BTOTAL

8 INPUT "ENTER DISTANCE FROM TOW CENTERLINE TO LEFT BANK ", BLEFT

INPUT "ENTER TOTAL CHANNEL AREA ", ATOTAL

INPUT "ENTER AREA LEFT OF TOW CENTERLINE ", ALEFT

INPUT "ENTER BARGE DRAFT ", D

INPUT "ENTER TOTAL BARGE WIDTH ", B

IF $\mathrm{B}<$ BLEFT AND B < BTOTAL - BLEFT THEN GOTO 9

PRINT "DISTANCE FROM VESSEL CENTERLINE TO BANK MUST BE > VESSEL BEAM" GOTO 8

9 INPUT "ENTER TOTAL LENGTH OF BARGES ", L

INPUT "ENTER AVERAGE CHANNEL VELOCITY, + FOR UPBOUND, - FOR DOWN ", VAM

10 INPUT "ENTER TOW SPEED RELATIVE TO GROUND ", VG

$\mathrm{V}=\mathrm{VG}+1.2 * \mathrm{VAM}$

GRAV $=32.16$

FLAG\$ = "N"

IF uni $\$=$ "M" THEN GRAV $=9.805$

IF uniS $=$ "m" THEN GRAV $=9.805$

LUNITS = "FEET "

VUNITS = "FEET/SEC"

AUNITS = "SQ FT"

IF uni $=$ "M" OR uni $=" m$ " THEN LUNIT $=$ "METERS"

IF uni\$ = "M" OR uni\$ $=" m$ " THEN VUNITS = "M/SEC

IF uni $=$ "M" OR uni $=$ "m" THEN AUNIT $\$=" S Q M "$

I

1 SET WATER VISCOSITY $=0.0000011 \mathrm{M} * * 2 /$ SEC FOR TEMP $=17$ DEG C

Figure 32. Listing for PC program NAVEFF (Sheet 1 of 12) 
VNU $=.0000011$

IF LUNIT $\$=$ "FEET" THEN VNU $=$ VNU *3.28*3.28

,

COMPUTE GEOMETRIC FACTORS

$\mathrm{AM}=\mathrm{B} * \mathrm{D}$

BRIGHT $=$ BTOTAL - BLEFT

ARIGHT = ATOTAL - ALEFT

NSIDEL $=2$ * ALEFT / AM

NSIDER $=2 \star A R I G H T / A M$

SKEWL = ATOTAL / $2 /$ ALEFT

$\mathrm{BLB}=$ BLEFT / BTOTAL

IF $\mathrm{BLB}>.9$ OR BLB < . 1 THEN FLAG\$ = "Y"

SKEWR = ATOTAL / $2 /$ ARIGHT

$\mathrm{BRB}=\mathrm{BRIGHT} / \mathrm{BTOTAL}$

IF $\mathrm{BRB}>.9$ OR BRB < . 1 THEN FLAG $\$=$ "Y"

IF FLAGS = "N" THEN GOTO 20

CLS

PRINT

PRINT " WARNING, THE DATA ENTERED FOR THE WIDTH ON ONE SIDE OF THE TOW ";

PRINT " IS LESS THAN 10\% OF THE TOTAL CHANNEL WIDTH. THIS IS OUTSIDE THE"; PRINT " LIMITS OF THE EXPERIMENTAL DATA."

FOR $I=1$ TO 15

PRINT

NEXT I

PRINT TAB(25); "Press SPACE BAR to continue"

SLEEP

CLS

IF L $>=.4 *$ BTOTAL THEN GOTO 14

CLS

PRINT

PRINT " WARNING, THE DATA ENTERED FOR THE VESSEL LENGTH ";

PRINT " IS LESS THAN $40 \%$ OF THE TOTAL CHANNEL WIDTH. THIS IS OUTSIDE THE"

PRINT " LIMITS OF THE EXPERIMENTAL DATA."

FOR $I=1$ TO 15

PRINT

NEXT I

PRINT TAB(25); "Press SPACE BAR to Continue"

SLEEP

14 CLS

$20 \mathrm{H}=$ ATOTAL / BTOTAL

$\mathrm{N}=$ ATOTAL / AM

$\mathrm{En}=\mathrm{N}$

IF $\mathrm{N}<85$ THEN GOTO 30

CLS

PRINT

PRINT " WARNING, THE BLOCKAGE RATIO IS GREATER THAN 85, WHICH IS OUTSIDE " PRINT " THE LIMITS OF THE EXPERIMENTAL DATA."

FOR $I=1$ TO 15

PRINT

NEXT I

PRINT TAB (25); "Press SPACE BAR to Continue"

SLEEP

30

CLS

REM 'SOLVE SCHIJF EQUATION FOR DISPLACEMENT CALCULATION

,

$z=.01$

Figure 32. (Sheet 2 of 12) 
40 SCHIJF $=(1+\mathrm{N} * \mathrm{Z} / \mathrm{H}) /(\mathrm{N}-\mathrm{I}-\mathrm{N} * \mathrm{Z} / \mathrm{H})$

$\mathrm{ZT}=(\mathrm{V} \star 2 / 2 /$ GRAV $) *((\mathrm{SCHIJF} \wedge 2)+2 *$ SCHIJF $)$

$\mathrm{U} 1=\mathrm{V} * \mathrm{SCHIJP}$

IF $\mathrm{ABS}((\mathrm{ZT}-\mathrm{Z}) / \mathrm{ZT})<.00001$ THEN GOTO 50

IF $\mathrm{Z}>20$ THEN GOTO 100

$\mathrm{Z}=\mathrm{ZT}$

50 REM

REM COMPUTE DISPLACEMENT THICKNESS

REM

VDISP $=V+U 1$

$\mathrm{RL}=\mathrm{VDISP} * \mathrm{~L} / \mathrm{VNU}$

DISP $=.292 * L /(.43429 *$ LOG $(R L)) \wedge 2.58$

$\mathrm{DE}=\mathrm{D}+\mathrm{DISP}$

$\mathrm{BE}=\mathrm{B}+2 * \mathrm{DISP}$

$\mathrm{N}=\mathrm{ATOTAL} / \mathrm{BE} / \mathrm{DE}$

REM 'SOLVE SCHIJF EQUATION FOR RETURN VELOCITY

$\mathrm{Z}=.01$

51 SCHIJF $=(1+\mathrm{N} * \mathrm{Z} / \mathrm{H}) /(\mathrm{N}-1-\mathrm{N} * \mathrm{Z} / \mathrm{H})$

$\mathrm{ZT}=(\mathrm{V} \wedge 2 / 2 / \mathrm{GRAV}) *((\mathrm{SCHIJF} * 2)+2 * \mathrm{SCHIJF})$

$\mathrm{U} 1=\mathrm{V} * \mathrm{SCHIJF}$

IF $\mathrm{ABS}((\mathrm{ZT}-\mathrm{Z}) / \mathrm{ZT})<.00001$ THEN GOTO 52

IF $Z>20$ THEN GOTO 100

$\mathrm{Z}=\mathrm{ZT}$

GOTO 51

52 REM

REM 'SOLVE SCHIJF EQUATION FOR LIMIT SPEED USING NEWTON RAPHSON

$\mathrm{VLO}=\mathrm{V}$

54 RTEM $=$ VLO $\curvearrowright 2 /$ GRAV / $\mathrm{H}$

$\mathrm{FV}=1-1 / \mathrm{N}+.5 * \mathrm{RTEM}-1.5 * \operatorname{RTEM} *(1 / 3)$

$\mathrm{FPV}=\mathrm{VLO} / \mathrm{GRAV} / \mathrm{H}-(\mathrm{VLO} \wedge(-1 / 3)) /(\mathrm{GRAV} * \mathrm{H}) \wedge(1 / 3)$

$\mathrm{VLN}=\mathrm{VLO}-\mathrm{FV} / \mathrm{FPV}$

IF ABS ( VLO - VLN $) /$ VLO $)<.0001$ THEN GOTO 55

VLO $=$ VLN

GOTO 54

$55 \mathrm{VL}=\mathrm{VLN}$

58 VLIMRAT $=\mathrm{V} / \mathrm{VL}$

PRINT

IF VLIMRAT > .35 THEN GOTO 59

PRINT "WARNING $* * \star * * * * *$ SPEED LESS THAN $0.35 *$ LIMIT SPEED $* * * * \star * * *$ "

59 IF VLIMRAT <.9 THEN GOTO 61

PRINT "WARNING $* \star \star * \star * * *$ SPEED GREATER THAN $0.9 *$ LIMIT SPEED $\star * \star \star \star \star \star \star \star * *$

61

APPLY CORRECTION FACTOR

$\mathrm{CF}=1.78-1.07$ * VLIMRAT

IF $\mathrm{CF}<1$ THEN $\mathrm{CF}=1$ !

$\mathrm{U} 1=\mathrm{CF} * \mathrm{U} 1$

$\mathrm{ZT}=(\mathrm{V}+\mathrm{U} 1) \wedge 2 / 2 / \mathrm{GRAV}-\mathrm{V} \wedge 2 / 2 / \mathrm{GRAV}$

PRINT

REM COMPUTE a (ALF) AND AVERAGE VI FOR EACH

REM SIDE OF TOW

VFACTL $=1.65-1.3 *$ BLB

IF $\mathrm{BLB}>.5$ THEN VFACTL $=1.35-.7 * \mathrm{BLB}$

VFACTR $=1.65-1.3 *$ BRB

IF $\mathrm{BRB}>.5$ THEN VFACTR $=1.35-.7 * \mathrm{BRB}$

Figure 32. (Sheet 3 of 12) 


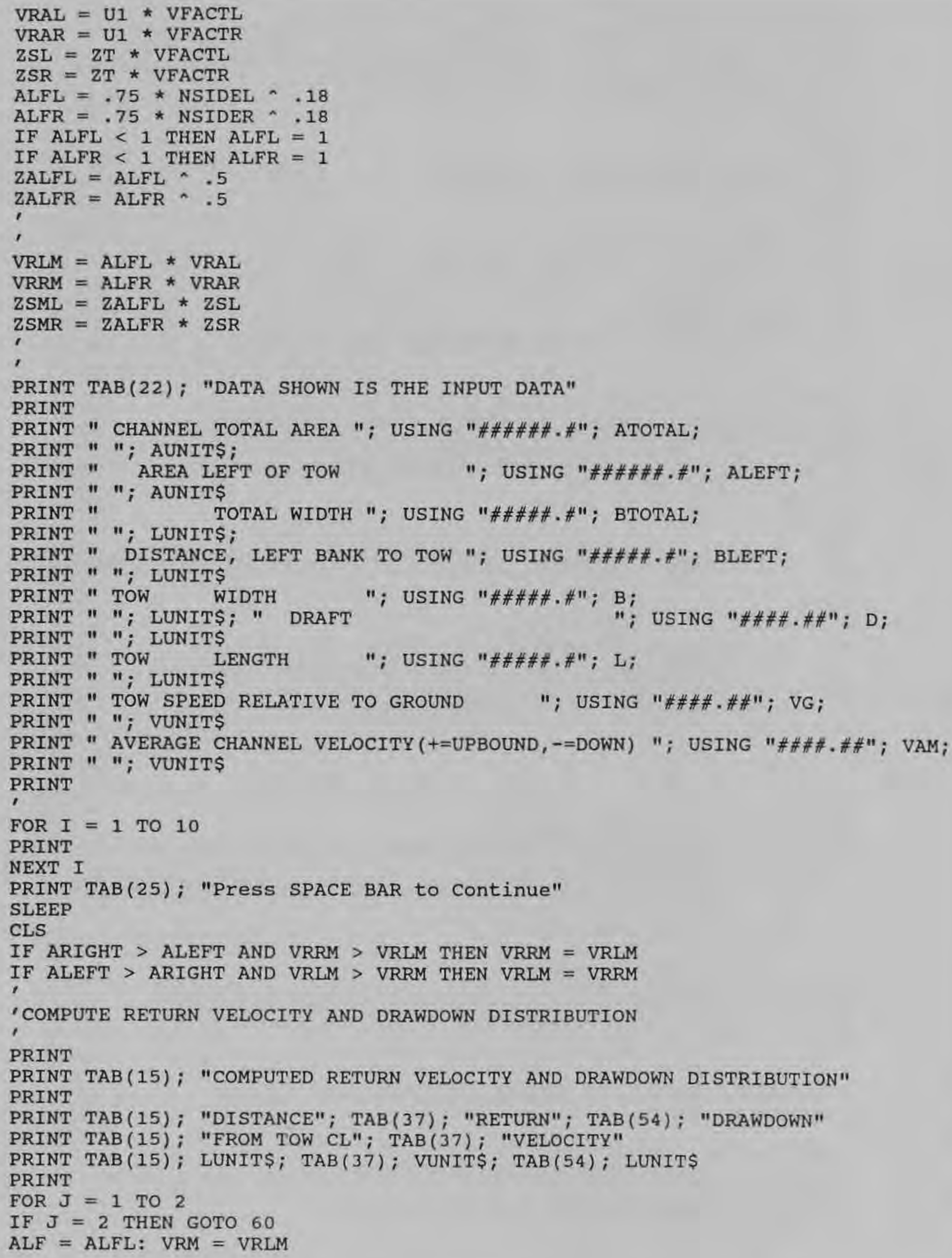

Figure 32. (Sheet 4 of 12) 
$\mathrm{ZALF}=\mathrm{ZALFL}: \mathrm{ZSM}=\mathrm{ZSML}$

$B S I D E=$ BLEFT

GOTO 70

60 ALF $=$ ALFR: VRM $=$ VRRM

$\mathrm{ZALF}=\mathrm{ZALFR}: \mathrm{ZSM}=\mathrm{ZSMR}$

BSIDE $=$ BRIGHT

$70 \mathrm{C}=3 ! *$ LOG $(1 / \mathrm{ALF})$

$\mathrm{ZC}=3 ! * \operatorname{LOG}(1 / \mathrm{ZALF})$

,

YLAST $=0$

FOR $I=1$ TO 5

IF $J=1$ THEN dum $=-$ BSIDE

IF $J=2$ THEN dum $=B$

$Y=($ dum $+(I-1) / 4 *(B S I D E-B))$

$Y Y=A B S(Y)$

$V Y=V R M * \operatorname{EXP}(C *(Y Y-B) /(B S I D E-B))$

$\mathrm{ZY}=\mathrm{ZSM} * \operatorname{EXP}(\mathrm{ZC}$ * $(\mathrm{YY}-\mathrm{B}) /(\mathrm{BSIDE}-\mathrm{B}))$

LOCAS = " "

IF $J=1$ AND $I=1$ THEN LOCA $\$="$ LEFT BANK"

IF $J=2$ AND $I=5$ THEN LOCA $\$="$ RIGHT BANK"

IF $(I=1)$ AND $(J=1)$ THEN $\mathrm{VYQL}=\mathrm{VY}: \mathrm{ZLQ}=\mathrm{ZY}$

IF $(I=1)$ AND $(J=2)$ THEN $V Y Q R=V Y: Z R Q=2 Y$

PRINT LOCA\$;

PRINT TAB (15); USING "\#\#\#\#.\#"; $\mathrm{Y}$;

PRINT TAB $(30)$; USING "\#\#\#\#\#\#\#.\#\#\#"; VY;

PRINT TAB (45); USING "\#\#\#\#\#\#\#\#\#\#\#\#"; ZY

YLAST $=Y$

NEXT I

NEXT $\mathrm{J}$

FOR $I=1$ TO 5

PRINT

NEXT I

PRINT TAB (25); "Press SPACE BAR to Continue"

SLEEP

GOTO 130

100 PRINT "SPEED EQUAL TO OR GREATER THAN VLIMIT" GOTO 10

130 CLS

PRINT

INPUT "

IF PRN $1=1$ THEN GOSUB PAPER

PRINT

INPUT " ENTER 1 FOR A VISUAL DISPLAY OF THE RESULTS"; ANS1

IF ANS1 $=1$ THEN GOSUB PICTURE

CLS

160 PRINT

INPUT " ENTER 1 FOR A NEW VESSEL SPEED OR 2 TO QUIT"; ANS2

IF ANS2 $=1$ THEN CLS : GOTO 10 ELSE CLS : END

PICTURE:

CLS

SCREEN 9

REM ADJUSTMENT FACTOR

$\mathrm{RAT}=560 /$ BTOTAL

$\mathrm{DMAX}=(.75) *((\mathrm{ALEFT} / \mathrm{BLEFT})+(\mathrm{ARIGHT} / \mathrm{BRIGHT}))$

DMRAT $=$ DMAX * RAT

SELECT CASE DMRAT

CASE IS $>60$

Figure 32. (Sheet 5 of 12) 
$\mathrm{m}=1$

CASE 40 TO 60

$\mathrm{m}=2$

CASE 26 TO 39

$\mathrm{m}=3$

CASE 20 TO 25

$\mathrm{m}=4$

CASE 1 TO 19

$\mathrm{m}=5$

END SELECT

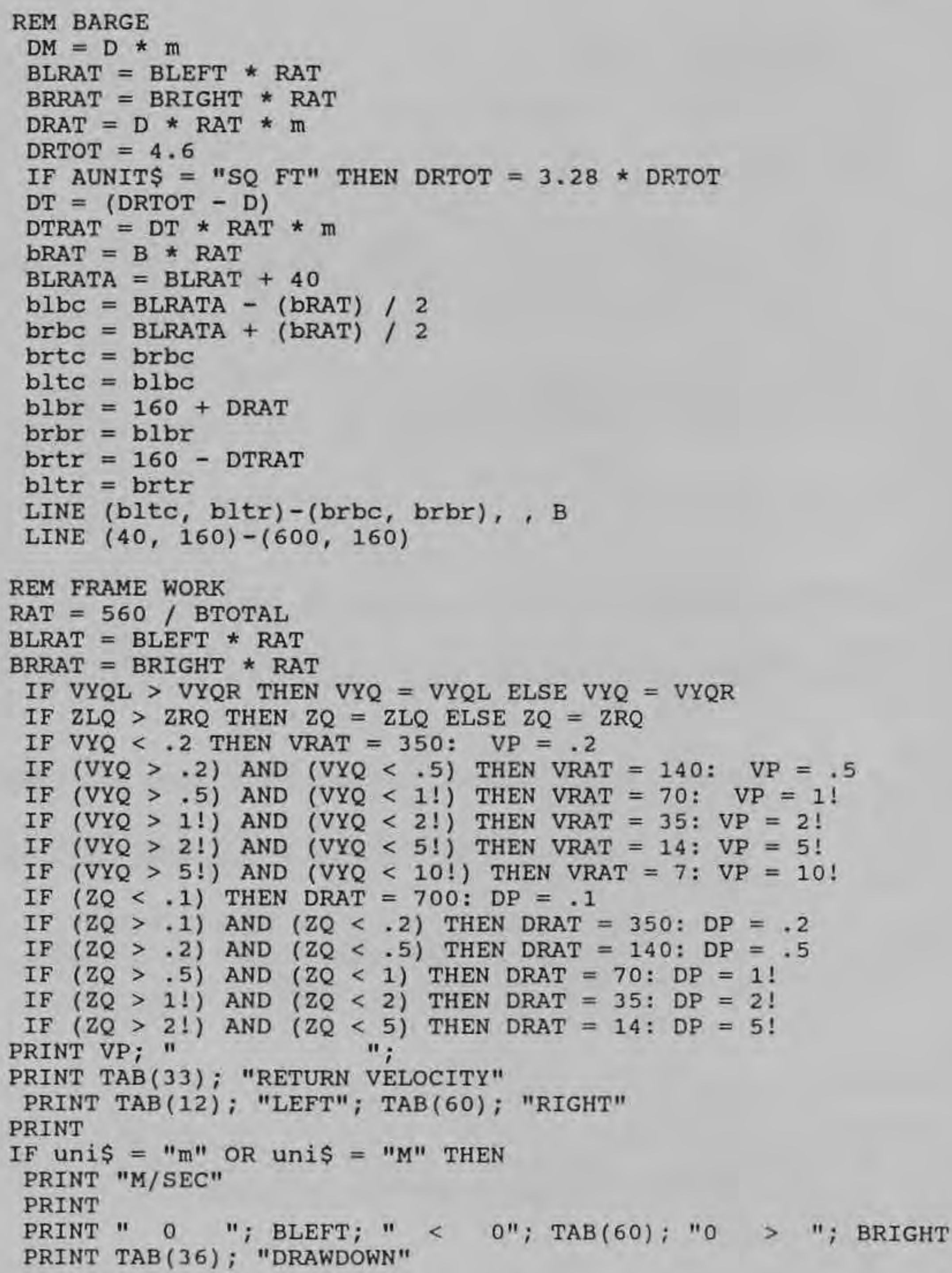

Figure 32. (Sheet 6 of 12) 


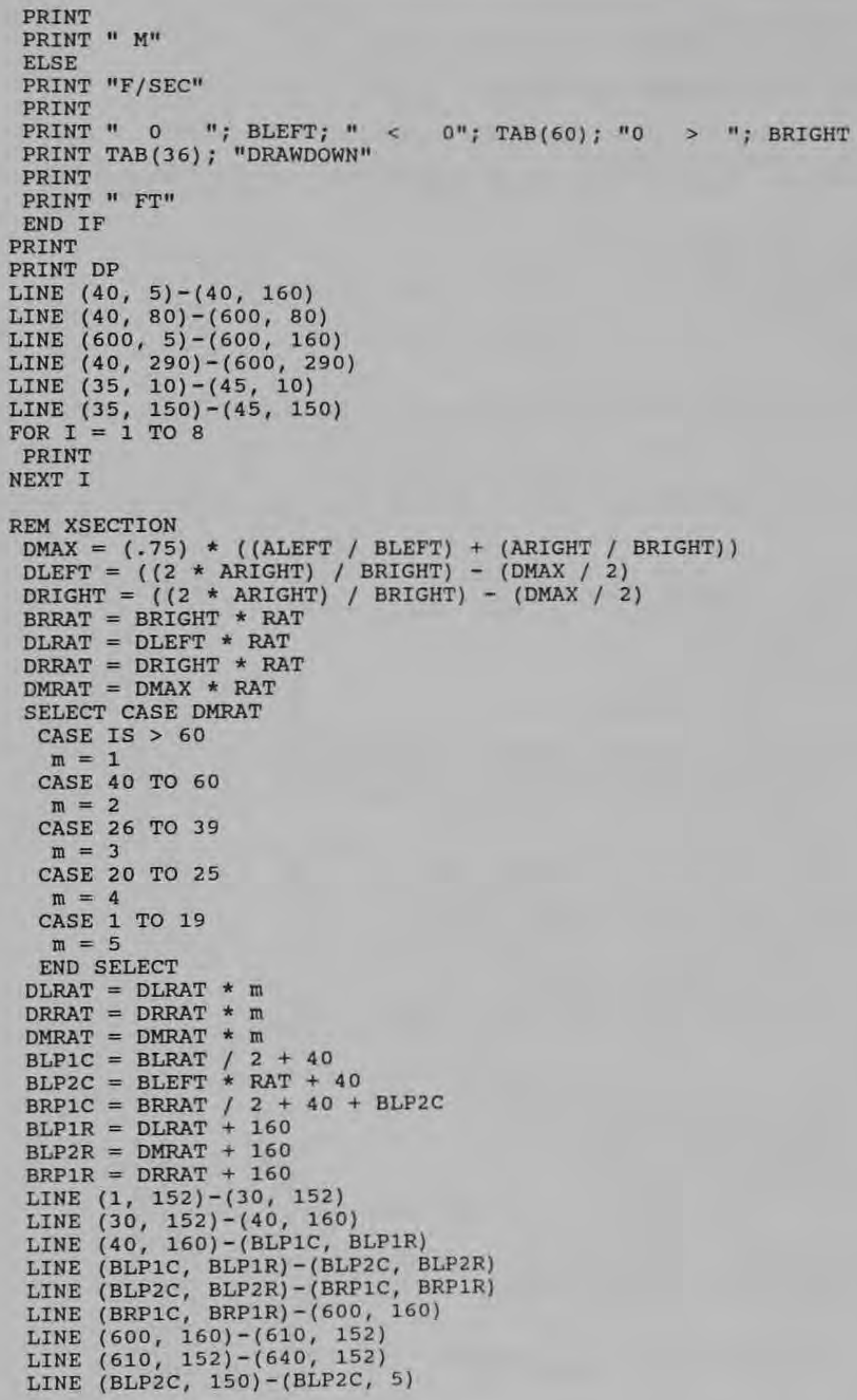

Figure 32. (Sheet 7 of 12) 


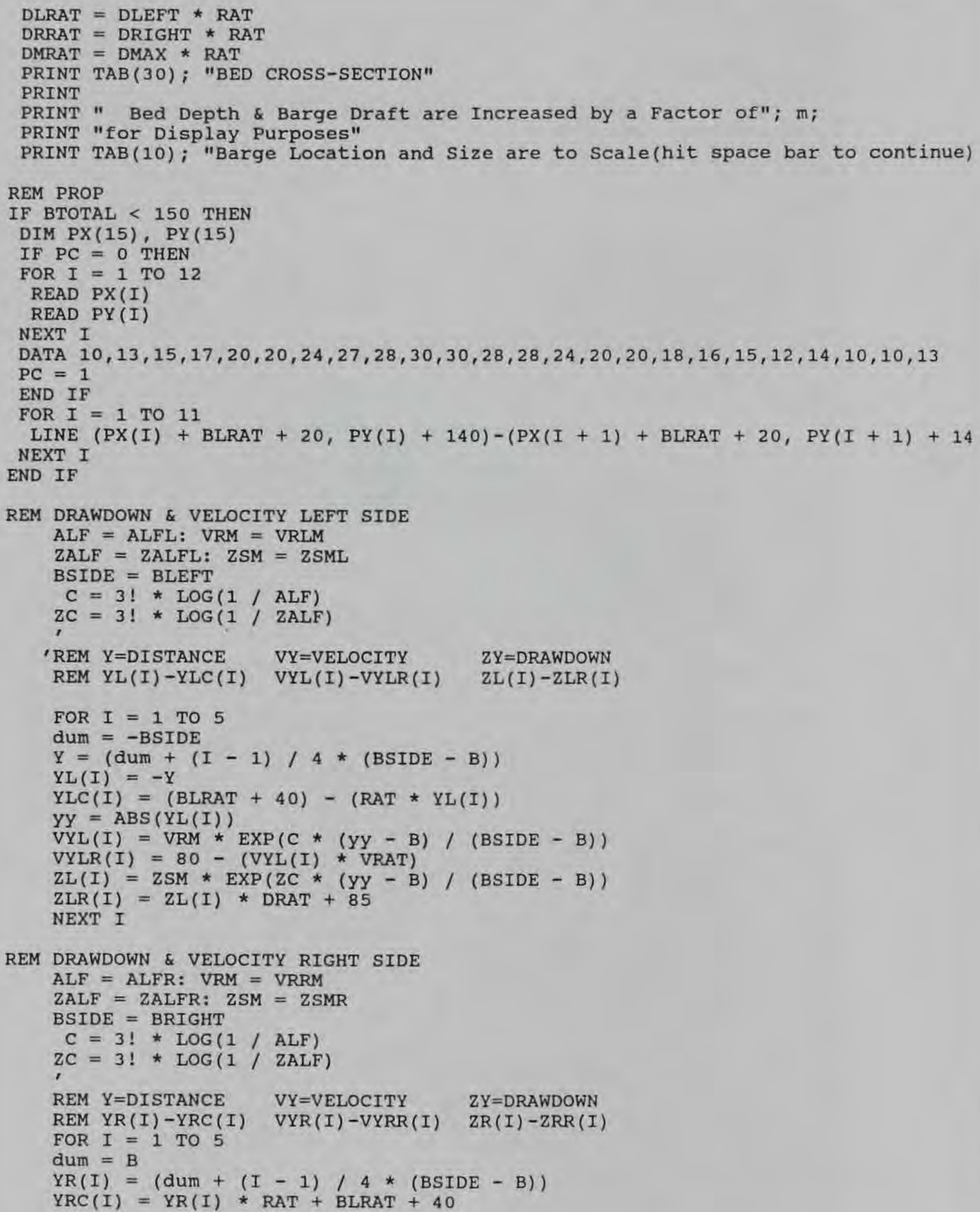

Figure 32. (Sheet 8 of 12) 
$Y Y=A B S(Y R(I))$

$\operatorname{VYR}(I)=\operatorname{VRM} * \operatorname{EXP}(C *(Y Y-B) /(B S I D E-B))$

$\operatorname{VYRR}(I)=80-(\operatorname{VYR}(I) * \operatorname{VRAT})$

$\mathrm{ZR}(I)=\mathrm{ZSM} * \operatorname{EXP}(\mathrm{ZC} *(\mathrm{YY}-\mathrm{B}) /(\mathrm{BSIDE}-\mathrm{B}))$

$\mathrm{ZRR}(I)=\mathrm{ZR}(I) \star \mathrm{DRAT}+85$

NEXT I

REM LOAD LINES INTO LINES. 1 FILE

OPEN "LINES. 1 " FOR OUTPUT AS \#1

FOR $I=1$ TO 5

IF $I=1$ THEN

PRINT \#1, "BM";

PRINT \#1, USING "\#\#\#"; YLC(I);

PRINT \#1, ",";

PRINT \#1, USING "\#\#\#"; VYLR(I);

END IF

IF $I>1<5$ THEN

PRINT \#1, " M" ;

PRINT \#1, USING "\#\#"; YLC(I);

PRINT \#1, ",";

PRINT \#1, USING "\#\#\#"; VYLR(I);

END IF

IF $I=5$ THEN

PRINT \#1, " M";

PRINT \#1, USING "\#\#"; YLC(I);

PRINT \#1, ",";

PRINT \#1, USING "\#\#"; VYLR(I) END IF

NEXT I

FOR $I=1$ TO 5

IF $I=1$ THEN

PRINT \#1，"BM" ;

PRINT \#1, USING "\#\#"; YLC(I);

PRINT \#1, ",";

PRINT \#1, USING "\#\#\#; $\operatorname{ZLR}(I)$;

END IF

IF $I>1<5$ THEN

PRINT \#1, "M";

PRINT \#1, USING "\#\#"; YLC (I) ;

PRINT \#1, ",";

PRINT \#I, USING "\#\#\#"; ZLR(I);

END IF

IF $I=5$ THEN

PRINT \#1, "M";

PRINT \#1, USING "\#\#"; YLC(I);

PRINT \#1, ",";

PRINT \#1, USING "\#\#"; ZLR(I)

END IF

NEXT I

FOR $I=1$ TO 5

IF $I=1$ THEN

PRINT \#1, "BM";

PRINT \#1, USING "\#\#"; YRC(I);

PRINT \#1, ",";

PRINT \#1, USING "\#\#"; $\operatorname{VYRR(I);~}$

END IF

IF $I>1<5$ THEN

PRINT \#1, "M";

PRINT \#1, USING "\#\#"; YRC(I);

PRINT \#1, ",";

Figure 32. (Sheet 9 of 12) 


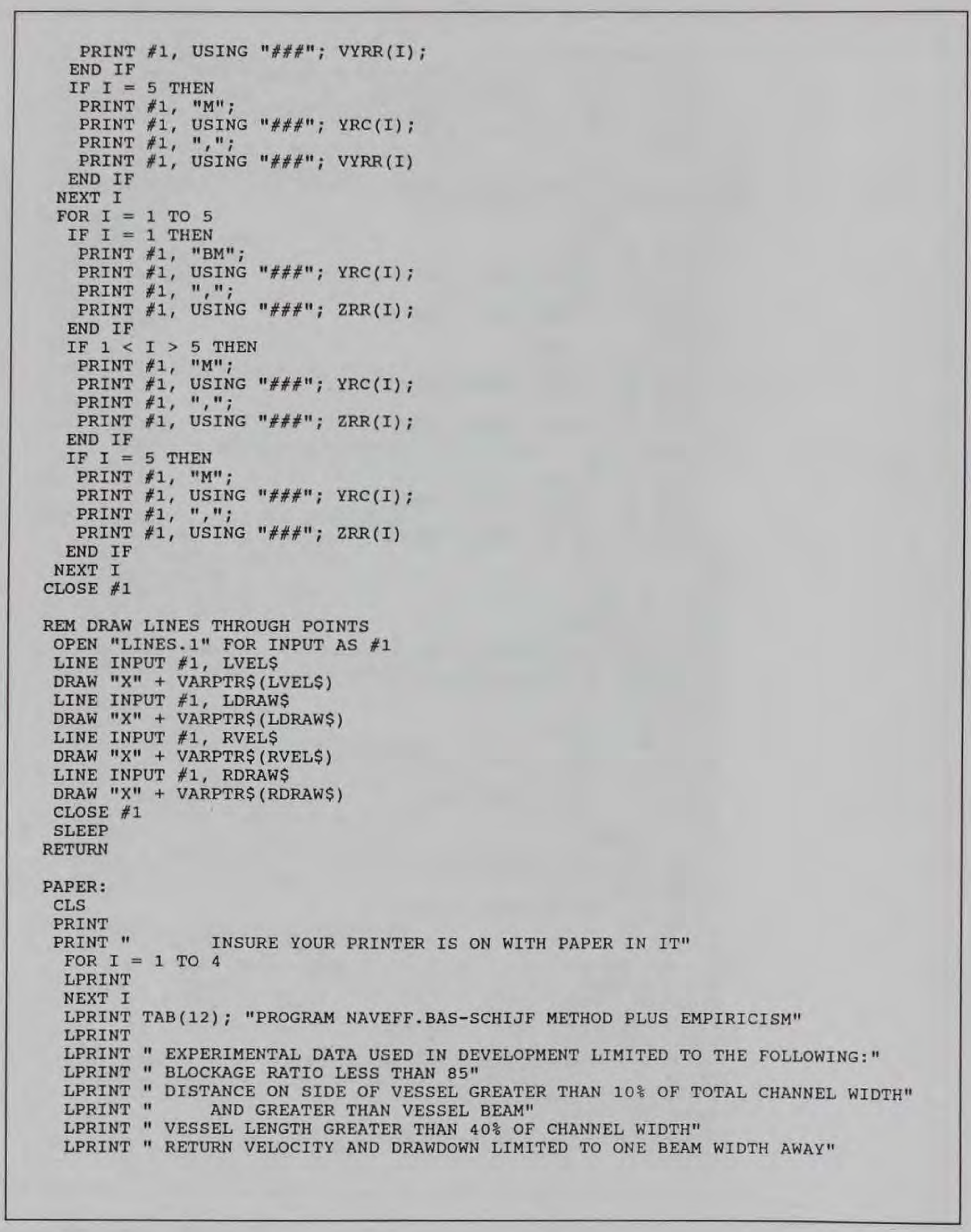

Figure 32. (Sheet 10 of 12) 
LPRINT " FROM VESSEL CENTERLINE OUT TO THE SHORELINE"

FOR $I=1$ TO 8

LPRINT

NEXT I

LPRINT TAB (25); "DATA SHOWN IS THE INPUT DATA"

LPRINT

LPRINT " CHANNEL TOTAL AREA "; USING "\#\#\#\#\#.\#"; ATOTAL;

LPRINT " "; AUNIT\$;

LPRINT " AREA LEFT OF TOW "; USING "\#\#\#\#.\#"; ALEFT;

LPRINT " "; AUNIT\$

LPRINT " TOTAL WIDTH "; USING "\#\#\#\#.\#"; BTOTAL;

LPRINT " "; LUNIT\$;

LPRINT " DISTANCE, LEFT BANK TO TOW "; USING "\#\#\#\#.\#"; BLEFT;

LPRINT " "; LUNITS

LPRINT "TOW WIDTH "; USING "\#\#\#\#.\#"; B;

LPRINT " "; LUNIT\$; " DRAFT "; USING "\#\#\#.\#\#"; D;

LPRINT " "; LUNIT\$

LPRINT " "; LUNITS

LPRINT " TOW SPEED RELATIVE TO GROUND "

LPRINT " "; VUNIT\$

LPRINT " AVERAGE CHANNEL VELOCITY(+=UPBOUND,-=DOWN) "; USING "\#\#\#.\#"; VAM;

LPRINT " "; VUNIT\$

LPRINT

IF VLIMRAT > .35 THEN GOTO 255

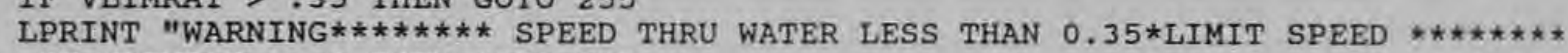

255 IF VLIMRAT <.9 THEN GOTO 257

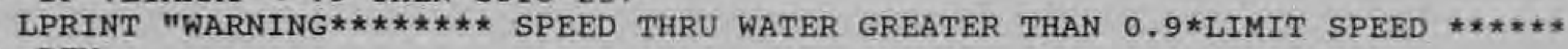
257 REM

FOR $I=1$ TO 5

LPRINT

NEXT I

LPRINT TAB(15); "COMPUTED RETURN VELOCITY AND DRAWDOWN DISTRIBUTION"

LPRINT

LPRINT TAB (15); "DISTANCE"; TAB (37); "RETURN"; TAB (54); "DRAWDOWN"

LPRINT TAB (15); "FROM TOW CL"; TAB(37); "VELOCITY"

LPRINT TAB(15); LUNIT\$; TAB(37); VUNIT\$; TAB(54); LUNIT\$

LPRINT

FOR $J=1$ TO 2

IF $\mathrm{J}=2$ THEN GOTO 260

$A L F=A L F L:$ VRM $=$ VRLM

$\mathrm{ZALF}=\mathrm{ZALFL}: \mathrm{ZSM}=\mathrm{ZSML}$

BSIDE = BLEFT

GOTO 270

260 ALF $=$ ALFR: VRM $=$ VRRM

$\mathrm{ZALF}=\mathrm{ZALFR}: \mathrm{ZSM}=\mathrm{ZSMR}$

BSIDE $=$ BRIGHT

$270 \mathrm{C}=3 ! *$ LOG $(1 /$ ALF $)$

$\mathrm{ZC}=3 ! \star \mathrm{LOG}(1 / \mathrm{ZALF})$

,

,

YLAST $=0$

FOR $I=1$ TO 5

IF $J=1$ THEN dum $=-$ BSIDE

IF $J=2$ THEN dum $=B$

$\mathrm{Y}=(\mathrm{dum}+(I-1) / 4 *(\mathrm{BSIDE}-\mathrm{B}))$

$\mathrm{YY}=\mathrm{ABS}(\mathrm{Y})$

$V Y=V R M * \operatorname{EXP}(C *(Y Y-B) /(B S I D E-B))$

$\mathrm{ZY}=\mathrm{ZSM} * \operatorname{EXP}(\mathrm{ZC} *(\mathrm{YY}-\mathrm{B}) /(\mathrm{BSIDE}-\mathrm{B}))$

LOCAS $="$ "

Figure 32. (Sheet 11 of 12) 


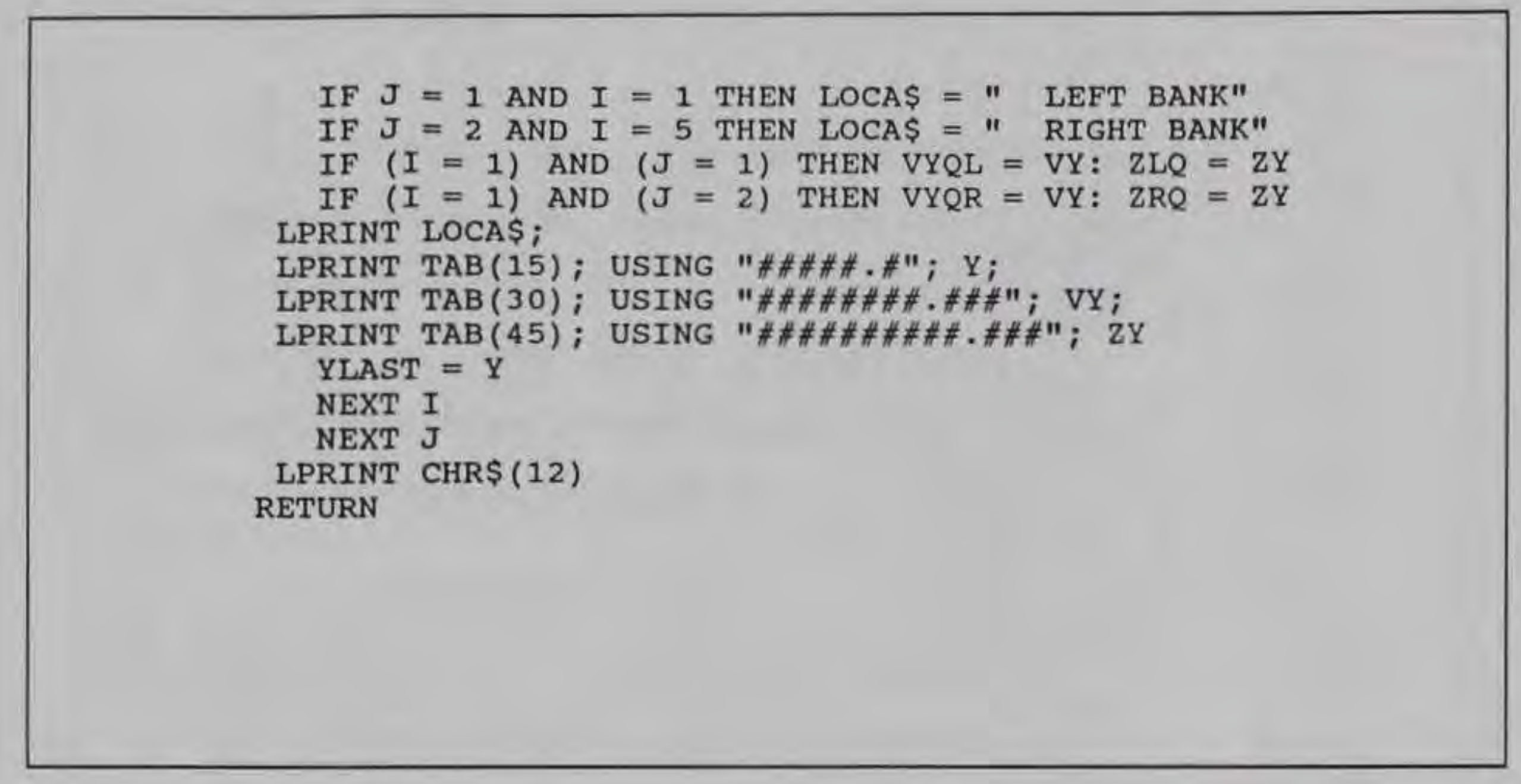

Figure 32. (Sheet 12 of 12)

exceeds the Schijf return velocity and prompts for a new speed. At the end of each tabular output, the program produces a screen image of the cross section, tow, and computed return velocity and drawdown.

Example Problem (based on WC Norman tow on Kampsville trip 1 field data:

a. Determine return velocity and drawdown distribution for a navigation channel having a 359-m top width and 1,309-sq-m cross-sectional area. The tow is $222 \mathrm{~m}$ from the left bank which results in a cross-sectional area left of the tow of $800 \mathrm{sq} \mathrm{m}$. The barges draft $2.74 \mathrm{~m}$, have a total beam of $32 \mathrm{~m}$, and a total length of barges of $238 \mathrm{~m}$. The downbound tow travels at $2.9 \mathrm{~m} / \mathrm{sec}$ relative to ground against an average ambient velocity of $0.49 \mathrm{~m} / \mathrm{sec}$.

$b$. Solution: Enter an " $\mathrm{m}$ " to indicate the use of metric units followed by the geometric factors. Enter an average channel velocity of $-0.49 \mathrm{~m} / \mathrm{sec}$, since this is a downbound tow. Enter a vessel speed relative to ground of $2.9 \mathrm{~m} / \mathrm{sec}$. The vessel length is used to ensure the ratio of vessel length/channel width exceeds 0.4 and to compute the displacement thickness to determine the effective draft and beam of the vessel. The program output is shown in Figure 33. 
PROGRAM NAVEFF.BAS-SCHIJF METHOD PLUS EMPIRICISM

EXPERIMENTAL DATA USED IN DEVELOPMENT LIMITED TO THE FOLLOWING:

BLOCKAGE RATIO LESS THAN 85

DISTANCE ON SIDE OF VESSEL GREATER THAN $10 \%$ OF TOTAL CHANNEL WIDTH

VESSEL LENGTH GREATER THAN $40 \%$ OF CHANNEL WIDTH

RETURN VELOCITY AND DRAWDOWN LIMITED TO ONE BEAM WIDTH AWAY

FROM VESSEL CENTERLINE OUT TO THE SHORELINE

DATA SHOWN IS THE INPUT DATA

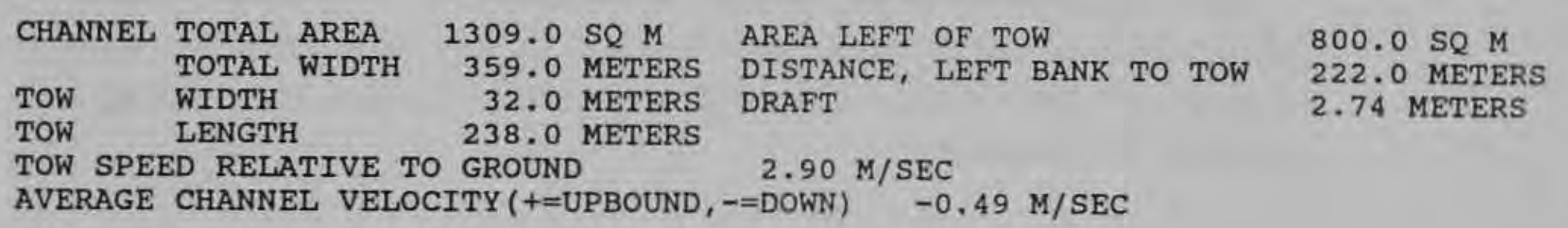

AVERAGE CHANNEL VELOCITY $(+=$ UPBOUND, $==$ DOWN $) \quad-0,49 \mathrm{M} / \mathrm{SEC}$

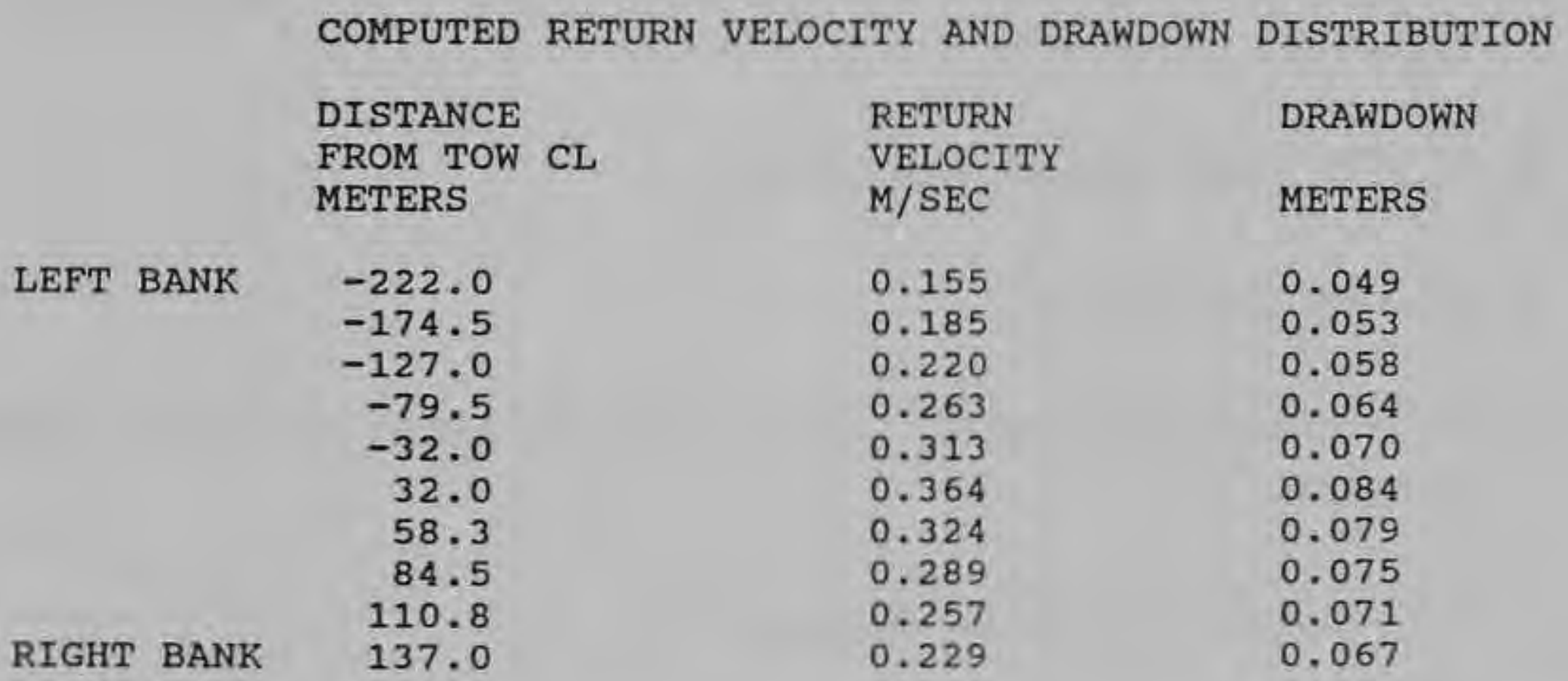

Figure 33. Output from PC program NAVEFF 


\section{Results and Conclusions}

The recommended 1995 analytical method presented herein is based on conservation of energy plus empiricism to define the distribution of return velocity and drawdown. The 1995 analytical method is summarized to compute the following:

a. Schijf return velocity and drawdown using Equations 1 and 2 .

b. Average return velocity using Equation 13.

c. Compute average return velocity on each side of the vessel using Equations 14 and 15.

d. $\mathrm{V}_{\mathrm{rsm}} / \mathrm{V}_{\mathrm{rs}}=\alpha$ using Equation 16

e. C using Equation 17.

f. $\mathrm{V}_{\mathrm{r}}(\mathrm{Y})$ using Equation $10 . \mathrm{V}_{\mathrm{r}}(\mathrm{Y})$ is linearly added to or from ambient currents.

g. $\mathrm{z}(\mathrm{Y})$ using Equations 18 through 22.

The 1995 analytical method should be limited to:

a. $\mathrm{N}$ less than 85 . While the vast majority of the data had $\mathrm{N}<52$, the limited data from the Clark's Ferry pool 572.7 physical model tests for $\mathrm{N}$ of about 85 resulted in significant scatter but exhibited the correct trend about the line of perfect agreement.

b. Tow length greater than 40 percent of the channel width.

c. Distance on both sides of tow center line equal to or greater than 10 percent of the total channel width.

d. Distance $\mathrm{Y}$ from the tow center line greater than tow width $\mathrm{B}$.

e. Vessel speed equal to 35 to 90 percent of the limiting speed. 
$f$. The predictive method presented herein, is applicable to river reaches that can be characterized by a single cross section. One would not expect these techniques to provide valid results at the end of an island or in other areas where the cross section varies rapidly.

Areas of needed research for this method are more data for $\mathrm{N}$ greater than 52 , variable tow length less than 0.4 times the channel width, and better data supporting the distribution of water-level drawdown. Future versions of the NAVEFF model will include propeller jet effects as well as short-period wave activity. 


\section{References}

Bhowmik, N. G., Soong, T. W., and Xia, R. (1993a). "Physical effects of barge tows on the Upper Mississippi River System: Analyses of existing data collected by the Illinois State Water Survey from the Clark's Ferry Site on the Mississippi River," (progress report no. 1 in preparation), Illinois State Water Survey, Champaign, IL.

. (1993b). "Physical effects of barge tows on the Upper

Mississippi River System: Analyses of existing data collected by the Illinois State Water Survey from the Kampsville Site on the Illinois River," (progress report no. 2 in preparation), Illinois State Water Survey, Champaign, IL.

Blaauw, H., and van der Knaap, F. (1983). "Prediction of squat of ships sailing in restricted water," Eighth International Harbour Congress, Antwerp, Belgium, 2.81-2.93.

Bouwmeester, J., van de Kaa, E. J., Nuhoff, H. A., and Orden, R. G. J. (1977). Twenty-fourth International Navigation Congress, Permanent International Association of Navigation Congresses, Leningrad, Russia, Section 1, Subject 3, 139-158.

Environmental Science and Engineering. (1981). "Navigation impact study," prepared for Illinois Natural History Survey, Grafton, IL.

Gates, E. T., and Herbich, J. B. (1977). "Mathematical model to predict the behavior of deep-draft vessels in restricted waterways,"

TAMU-SG-77-206, Texas A\&M Ocean Engineering Program, College Station, TX.

Hochstein, A. B., and Adams, C. E. (1989). "Influence of vessel movements on stability of restricted channels, "Journal of Waterway, Port, Coastal, and Ocean Engineering. American Society of Civil Engineers, 115(4), 444-465. 
Maynord, S. T. (1990). "Velocities induced by commercial navigation," Technical Report HL-90-15, U.S. Army Engineer Waterways Experiment Station, Vicksburg, MS.

Maynord, S. T., and Martin, S. K. (1996a). "Physical model study of navigation effects on Illinois River at Kampsville, IL" (technical report in preparation), U.S. Army Engineer Waterways Experiment Station, Vicksburg, MS.

Maynord, S. T., and Martin, S. K. (1996b). "Physical model study of navigation effects on Mississippi River at Clarks Ferry, IL," (technical report in preparation), U.S. Army Engineer Waterways Experiment Station, Vicksburg, MS.

Maynord, S. T., and Siemsen, T. S. (1991). "Return velocities induced by shallow-draft navigation." Proceedings of the 1991 National Conference on Hydraulic Engineering. American Society of Civil Engineers, R. M. Shane, ed., New York, 894-899.

Permanent International Association of Navigation Congresses. (1987).

"Guidelines for the design and construction of flexible revetments incorporating geotextiles for inland waterways," Report of Working Group 4. Permanent Technical Committee 1, Supplement to Bulletin No. 57 , Brussels, Belgium.

Schijf, J. B. (1949). Seventeenth International Navigation Congress, Lisbon, Portugal, Section 1, Subject 2, 61-78.

Schlicting, H. (1968). Boundary-layer theory, McGraw-Hill, New York.

Simons, D. B., Simons, R. H., Ghaboosi, M., and Chen, Y. H. (1988).

"Physical impacts of navigation on the Upper Mississippi River Systems," U.S. Army Engineer District, St. Louis, St. Louis, MO.

Tothill, J, T. (1966). "Ships in restricted channels - A correlation of model tests, field measurements, and theory." Department of Transport, National Research Council, Ottawa, Canada.

U.S. Army Engineer District, Huntington. (1980), "Gallipolis Locks and Dam Replacement, Ohio River, Phase 1, advanced engineering and design study, General Design Memorandum; Appendix J, Volume 1, environmental and social impact analysis," Huntington, WV. 


\section{Appendix A Notation}

$A_{c} \quad$ Undisturbed channel area

$A_{\mathrm{w}} \quad$ Disturbed channel area around midsection of vessel

$A_{m} \quad$ Submerged cross-sectional area of vessel at midsection

$\beta \quad$ Coefficient that varies with $V / V_{L}$ in the Schijf equations to improve agreement between observed and computed return velocity and drawdown.

$B_{o} \quad$ Channel width

$B \quad$ Beam of vessel

$B_{\text {side }} \quad$ Distance from vessel center line to shoreline

g Gravitational acceleration

$h \quad$ Undisturbed average water depth

$L \quad$ Vessel length

$N \quad$ Ratio of channel cross-sectional area to vessel cross-sectional area

$V \quad$ the vessel speed

$V_{L} \quad$ Maximum speed (called the critical or limiting speed)

$V$, Average return velocity

$V_{m} \quad$ Maximum return velocity

$V_{r s} \quad$ Average return velocity for each side of vessel

$V_{r m m} \quad$ Maximum return velocity on each side of the tow 
$V_{r}(Y)$ Maximum return velocity during tow event

$Y \quad$ Distance from center line of vessel

$z \quad$ Average water-level drawdown

$Z_{r s} \quad$ Average drawdown for each side of vessel

$Z_{s m} \quad$ Maximum drawdown for each side of vessel

$Z(Y)$ Maximum water-level drawdown during tow event 


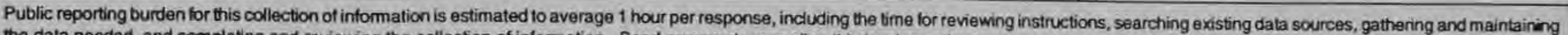

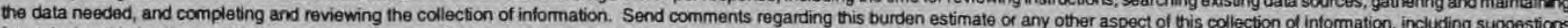

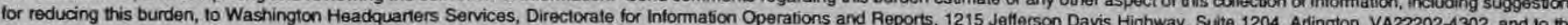
Office of Management and Budgel, Paperwork Reduction Project (0704-0188), Washington, DC20503.
1. AGENCY USE ONLY (Leave blank)
2. REPORT DATE
August 1996
3. REPORT TYPE AND DATES COVERED
Final report

4. TITLE AND SUBTITLE

Return Velocity and Drawdown in Navigable Waterways

5. FUNDING NUMBERS

6. AUTHOR(S)

Steve Maynord

7. PERFORMING ORGANIZATION NAME(S) AND ADDRESS(ES)

U.S. Army Engineer Waterways Experiment Station

3909 Halls Ferry Road, Vicksburg, MS 39180-6199

8. PERFORMING ORGANIZATION REPORT NUMBER

Technical Report HL-96-7

9. SPONSORINGMONITORING AGENCY NAME(S) AND ADDRESS(ES)

U.S. Army Corps of Engineers

10. SPONSORING/MONITORING

Washington, DC 20314-1000

AGENCY REPORT NUMBER

\section{SUPPLEMENTARY NOTES}

Available from National Technical Information Service, 5285 Port Royal Road, Springfield, VA 22161.

12a. DISTRIBUTIONAVAILABILITY STATEMENT

Approved for public release; distribution is unlimited.

12b. DISTRIBUTION CODE

\section{ABSTRACT (Maximum 200 words)}

An analytical method for estimating return velocity and drawdown is developed based on physical model study data for the Kampsville reach, Illinois River and the Clark's Ferry reach, Mississippi River. The analytical method uses conservation of energy plus empiricism to define the distribution of maximum return velocity and maximum drawdown during the tow event. The method is compared to prototype retum velocity and drawdown data from two sites on the Illinois River, two on the Mississippi River, and four on the Ohio River.

14. SUBJECT TERMS

Barges

Drawdown

Navigation
Return velocity

Shallow draft navigation

Tows
15. NUMBER OF PAGES

102

16. PRICE CODE
17. SECURITY CLASSIFICATION OF REPORT

UNCLASSIFIED
18. SECURITY CLASSIFICATION OF THIS PAGE

UNCLASSIFIED

NSN 7540-01-280-5500 